\title{
Neoconservatism and American Foreign Policy: A Critical Analysis
}

\author{
Danny Cooper \\ BCom (Hons) Griff \\ Department of International Business and Asian Studies \\ Griffith Business School \\ Griffith University
}

Submitted in fulfilment of the requirements of the degree of Doctor of

Philosophy

July 2009 
, '

$$
\because \quad \therefore
$$




\begin{abstract}
$\underline{\text { Abstract }}$
This thesis critically engages with the dominant ideas, beliefs, and strategic thought of neoconservative foreign policy intellectuals. Much has been made in the dominant studies on neoconservatism of the ideological conversion neoconservatives underwent throughout the twentieth century. Understanding this conversion is certainly important if one is to develop an appreciation of neoconservatism's history. Yet this thesis argues that neoconservatism is best understood by critically engaging with a body of ideas and beliefs which should define the neoconservative approach to American foreign policy.

Neoconservatives have contributed greatly to both domestic and foreign policy debates in the United States. This thesis, however, focuses on their contributions in the realm of international affairs. Although they were first renowned for their warnings against the unintended consequences of ambitious social policies, most often those associated with Lyndon Johnson's 'Great Society' programs, neoconservatives are no longer identified as strongly with domestic policy. Following the Cold War, they came to write almost exclusively on America's foreign relations.

In this thesis, I argue that neoconservatism is best understood through the ideas and beliefs of its leading foreign policy intellectuals. First, I examine the neoconservative conception of the national interest, emphasising the importance neoconservatives attach to a less tangible national interest: protecting the national idea of America. Second, I critically examine what is described as the neoconservative "war of ideology," asking whether it is desirable to place such a strong emphasis on ideology in international affairs. Third, I assess neoconservative views on international order and unipolarity. And fourth, I examine neoconservative ideas on American power. These are, in short, the four dominant chapters comprising the body of this thesis. Neoconservative views in each of the areas, I argue, should define the neoconservative approach to American foreign policy.
\end{abstract}




\section{TABLE OF CONTENTS}

1) Introduction.................................................... 1

2) Neoconservatism and its Authors ............................ 34

3) Protecting the National Idea of America ...................6 65

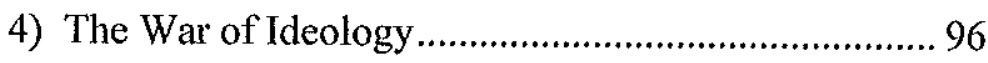

5) International Order and American Preponderance .... 133

6) American Power and Preventive War....................... 165

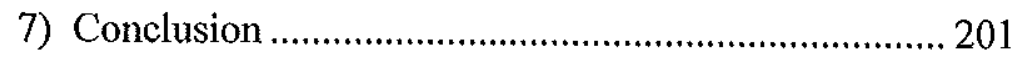

List of References .............................................. 221 


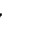


When an idea, whether just or unreasonable, takes possession of the American mind, nothing is more difficult than to get rid of it.

Alexis de Tocqueville 


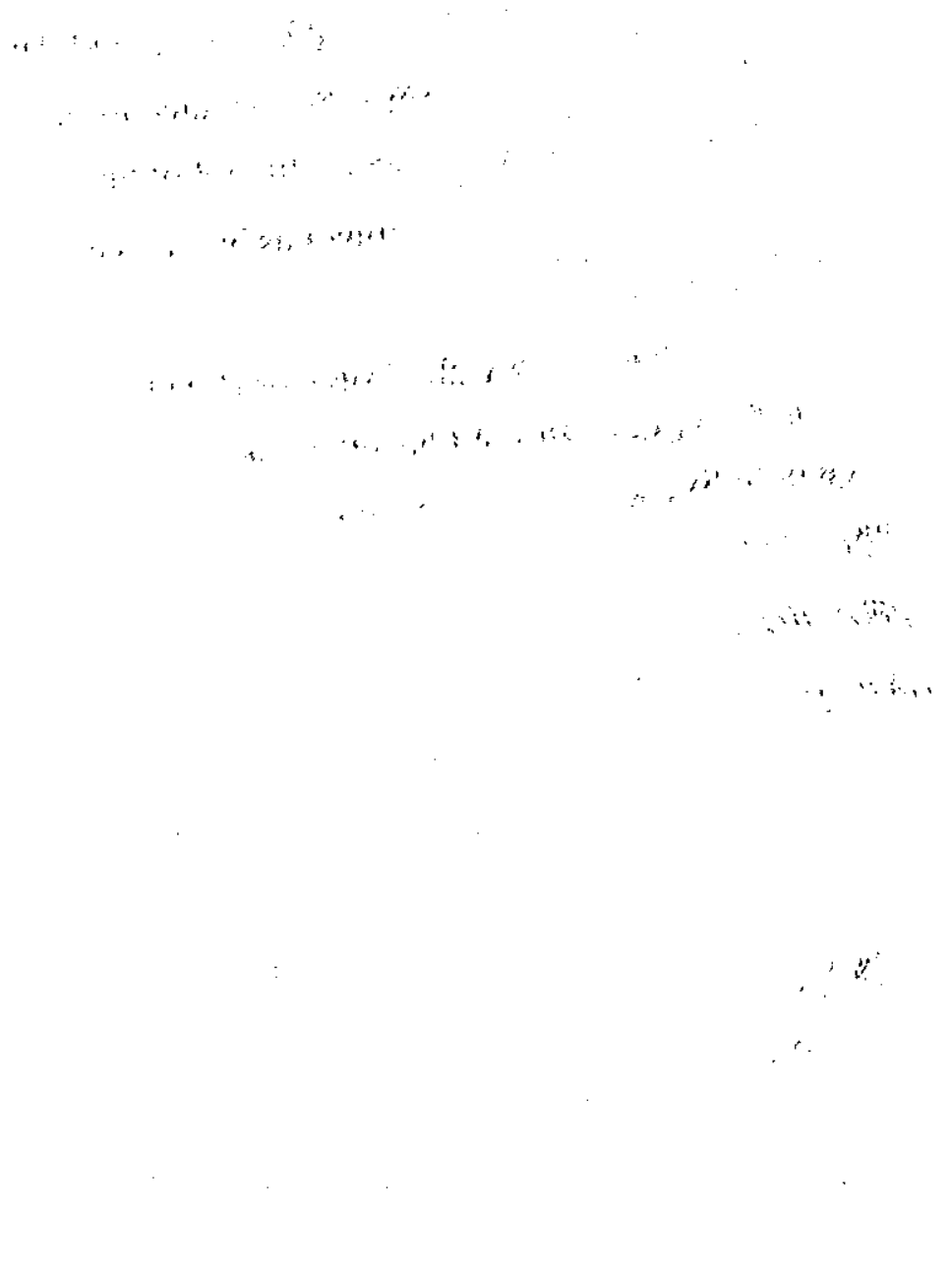

tis 


\section{Acknowledgements}

Below is a very brief list of scholars, colleagues, and family members who have provided a degree of support which has made this project both possible, and even a little enjoyable.

Before I identify three colleagues in particular, I sincerely thank all those who have read segments of this thesis, and commented on its contents.

First, I sincerely thank my principal supervisor, Associate Professor Martin Griffiths. Martin is an expert in international relations theory and American foreign policy, and has been a much needed fount of insight, guidance, and humour. $\mathrm{He}$ contributed significantly to the framing of the argument in this thesis, and was always forthcoming with suggestions that have undoubtedly improved the final product. Martin has regularly made himself available to discuss my ideas and allay my never ending concerns, for which I am very grateful.

Second, I am very much indebted to my associate supervisor, Professor John Kane. John is an expert in political theory and American foreign policy, and his expertise was both needed and appreciated as he read and made comments on the final draft of this thesis. As a former student of his, I am glad to have had an opportunity to work with John on this project as his advice has never failed to point me in the right direction.

Last, I thank Associate Professor Brendon O'Connor. Although Brendon was my principal supervisor until he left to take a new position at the United States Studies Center in Sydney, he has remained an important source of advice. As I have moved along in the world of academia, Brendon has always been willing to review my work, generally in a supervisory role. He has served as a very valuable mentor for me. If I owe anyone in the academic field for whatever small portion of success I may yet attain, it is surely Brendon.

Finally, I thank all those friends and family members who have provided moments of levity and comfort which have assisted me get through this project. I especially thank my parents who have always been there for me, providing me with a never ending stream of support and advice. They taught me, albeit in their own unique ways, the importance of the one thing President Harry S. Truman said could never be taken away from a person: an honourable reputation and a good name. 


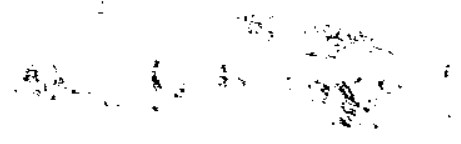

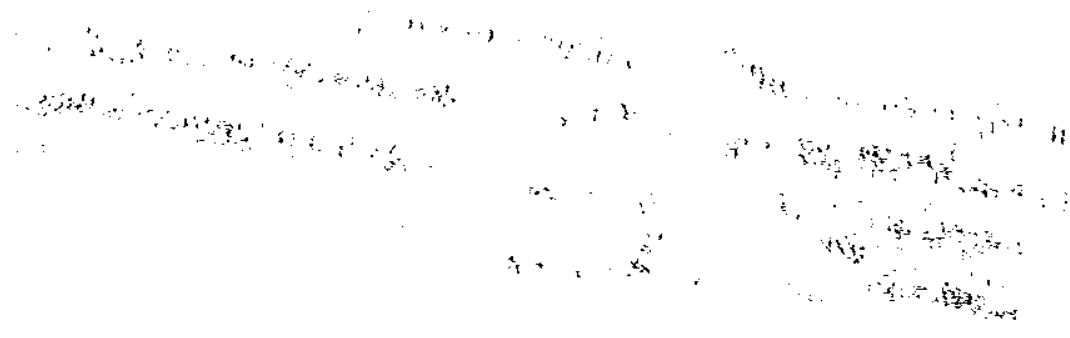$$
5
$$ 


\section{Statement of Originality}

This work has not previously been submitted for a degree or diploma in any university. To the best of my knowledge and belief, the thesis contains no material previously published or written by another person except where due reference is made in the thesis itself. 



\section{Chapter One}

\section{$\underline{\text { Introduction }}$}

Those who write about neoconservatism often struggle to define it. Is a neoconservative "a liberal who has been mugged by reality," as Irving Kristol, the progenitor of neoconservatism, once quipped? ${ }^{1}$ Is neoconservatism a "Jewish mindset," one shaped by the horrors of the Nazi holocaust, as many claim? ${ }^{2}$ Or are neoconservatives, as some imply, best thought of as an institutional network of like minded thinkers who spend their lives writing for think tanks and journals, jostling for influence over those elected to lead $?^{3}$ In contrast, neoconservatism, I argue, should be defined by the ideas and beliefs of its leading intellectuals, especially those who write most prolifically on American foreign policy.

Although neoconservatives became an object of fascination throughout the Bush era, they remain as relevant today as they were on September 12, 2001. They have been an integral part of America's national life for several decades, writing on both domestic and foreign policy. Even when they appear marginalised, neoconservatives are always preparing for the future, knowing that nothing is permanent in American politics. If their ideas are to shape the future, neoconservatives know that they must be developed at times when their prospects of shaping policy appear dim. This is certainly true in an era in which the Democrats appear ascendant and America has the most popular Democratic president since Woodrow Wilson, Barack Obama.

The term "neoconservative" itself is one which engenders much debate and visceral reaction. There is certainly no consensus on how neoconservatism should be defined or thought about, although there have been no shortage of observers who have been eager to apply the label to whomever they hope it will taint. As Douglas Murray fairly argues, "Rarely has a term been thrown around so wildly while its meaning remains so popularly elusive" (Murray, 2006: xvi). All studies on neoconservatism attempt to demystify its meaning, this one included.

\footnotetext{
${ }^{1}$ For this famous quote, see Kristol, 2005. The quote was taken out of a 2005 edition of The Christian Science Monitor, an edition which published a very good collection of the most famous quotations of neoconservatives.

${ }^{2}$ Although I examine the arguments of scholars who have attempted to link neoconservatism to the ideas of Leo Strauss in the following chapter, for an introduction into the work of the one author who has made this argument most forcefully, see Heilbrunn, 2008.

${ }^{3}$ For a much older study which emphasises the degree to which neoconservatives attempted to shape domestic policy in the U.S., see Steinfels, 1979. For a more recent study which, inter alia, examines neoconservative links with centres of influence, see Halper \& Clarke, 2004: Ch. 6.
} 
The first two chapters of this thesis will indulge many of the customary academic expectations associated with writing a dissertation - outlining the argument to follow, explaining the merits of the adopted methodology, and reviewing the existing literature. Yet it is important to note that neoconservatives retain considerable relevance and significance not only because of their own ideas and alleged influence over the Bush administration, but because of what their ideas and beliefs may tell us about America and its political culture. There has always been a considerable amount of ideational continuity in policy debates in the United States, especially in the realm of American foreign policy, which is the field in which this thesis primarily concerns itself. In his superbly written account of America's foreign policy traditions, Walter Russell Mead argues, "many of the ideas and alternatives present in contemporary discussions would have been familiar to American politicians and thinkers throughout our history" (Mead, 2002: 87).

Mead was writing throughout the opening years of the Bush presidency. Yet the argument is just as applicable today. The debates neoconservatives have engaged in are not that different from the debates that have taken place in America's past. There are, of course, unique features of neoconservatism which merit emphasis. But many of the dilemmas and challenges neoconservatives confront have been dilemmas and challenges long confronted by American statesmen and intellectuals of both the highest and lowest calibre. How should the national interest be defined? What role should ideology play in the conduct of American foreign policy? What should America's contribution be to creating a more orderly world? How should American power be employed? Neoconservative responses to these questions should define the neoconservative approach to American foreign policy.

Yet these are also questions that Americans have faced since the birth of their republic. Sometimes the answers provided to such questions have been wise, sometimes they have been reckless. Should America be a "promised land" or a "crusader state," a question at the forefront of Walter McDougall's thoughtful history on American foreign policy? (see McDougall, 1997). Neoconservatives have answered this question with no less conviction and sincerity than have preceding generations of intellectuals and policy-makers.

Neoconservatives do not see America as an ordinary country. But then, as John Kane persuasively argues, neither America nor the world has ever seen America as ordinary (see Kane, 2008: 425). The sense of national mission and exceptionalism 
infusing the country's political culture, according to Anatol Lieven, has made "it much more difficult for most Americans to imagine the United States as a country among others or an 'international community' that includes America as a member rather than a hegemon" (Lieven, 2006: 63).

This has always had consequences for the way in which America has responded to the problem of world order. When the Cold War ended, much was made about the arrival of a "unipolar moment." As I argue at length in a later chapter, the strategic logic supporting neoconservative calls to perpetuate American military preponderance, while arguably flawed, was quite sophisticated. But the calls were also overlaid by the belief that only America could be trusted to wield such enormous power. Reinforcing this sense was Ben Wattenberg's observation that "A unipolar world is a good thing, if America is the uni" (cited in Dorrien, 1994: 330). Such observations are a product of a national faith in the fundamental goodness of America. 'This belief in American innocence, of 'original sinlessness,' is both very old and very powerful," Lieven argues (Lieven, 2004: 53).

So while neoconservatives were among the loudest supporters of the 2003 Iraq War, the questions they have attempted to answer are questions that have been asked by generations of Americans. Their answers provide one set of alternatives to questions that have frustrated the American mind. Enmeshed in America's national life, neoconservatives have taken part in some of the most pressing and significant foreign policy debates, making an understanding of America's modern history incomplete if their contributions go without scrutiny.

When the Nixon-Kissinger administration reached out to China and pursued détente with the Soviet Union, neoconservatives and "Scoop" Jackson Democrats aired the loudest protests. When Ronald Reagan found a willing negotiating partner in Mikhail Gorbachev, neoconservatives spoke out against the false expectations of international summitry. When nineteen Middle Eastern terrorists hijacked four commercial airliners on September 11, 2001, turning them into missiles which destroyed the World Trade Center and parts of the Pentagon, neoconservatives were quick to shape the national debate. Whatever the national challenge, neoconservatives have always had a ready stockpile of ideas and beliefs promising to usher in a less dangerous world.

The purpose of this thesis is to define neoconservatism through the ideas and beliefs of its leading foreign policy intellectuals. It is the fundamental premise of this 
thesis that neoconservatives must be understood as they understand themselves. Ideas must be taken seriously by those studying neoconservatism, if only because they are taken so seriously by neoconservatives. This chapter begins by arguing that a thematic and ideational approach to studying neoconservatism yields insights which illuminate the main foreign policy goals and core strategic assumptions of neoconservatives. It also begins by analysing the importance neoconservatives assign to ideas in politics, focussing specifically on the two intellectuals who gave neoconservatism its distinctive cast, Irving Kristol and Norman Podhoretz. Shaped by what political scientists call interpretive theory, this chapter emphasises the importance of ideas and beliefs in the world of international politics and in the study of neoconservatism.

Although they have been the subject of much academic inquiry and extravagant commentary, no scholar has rigorously examined neoconservative ideas and beliefs collectively. ${ }^{4}$ This thesis attempts to fill this void. Before these ideas and beliefs are examined, this chapter defends the adopted approach and methodology, and clarifies several points of contention raised by those who have written about neoconservatism. No question has been as hotly contested as the question of neoconservative "influence" over the Bush administration. It is important to understand, though, that whatever one's views on this question, neoconservatives do aspire to shape policy. Just as importantly, if not more so, they aspire to foster an intellectual climate hospitable to their ideas and beliefs. It is for this reason that neoconservative ideas must be taken seriously even at a time when they appear to have lost some of their post-September 11 magnetism.

While neoconservatism was initially associated with domestic policies relating to the overambitiousness of Lyndon Johnson's Great Society programs, this thesis focuses exclusively on international affairs. At the end of the Cold War, neoconservatism was no longer a distinctive force in the realm of domestic policy. Irving Kristol had explained that it "was a generational phenomenon, and has now been pretty much absorbed into a larger, more comprehensive conservatism" (Kristol, I. 1995/1999: 40). ${ }^{5}$ While this remained true in the realm of domestic policy, it was not exactly true in the realm of foreign policy, a field in which neoconservatives

\footnotetext{
${ }^{4}$ Two exceptions are Francis Fukuyama and Steven Hurst. I will draw attention to the work of these scholars shortly, and will explain why their respective depictions of neoconservatives are problematic. ${ }^{5}$ When two years appear in in-text citations, the former refers to when the article was originally written (or when a speech was delivered); the latter refers to the year it was published in an edited volume.
} 
retained a distinctive set of foreign policy ideas. In fact, neoconservatism is now almost exclusively identified with American foreign policy.

It has often been said by neoconservatives, both throughout the Johnson years of alleged domestic overreach and in international politics, that "ideas have consequences," so much so that it has become something of a trite observation. Yet the assertion's widespread acceptance should not undercut its significance. Neoconservatives have spent most of their careers surveying the ideational terrain, making sure that no "threatening" ideas were left unchecked. It is, therefore, imperative that neoconservative ideas and beliefs receive the same level of attention that neoconservatives extend to others. After all, although few intellectuals challenge the claim that "ideas have consequences," few have devoted themselves as wholeheartedly to an intellectual life guided by this maxim as the neoconservatives whose work I examine in the following pages.

\section{Defining Neoconservatism: The Case for an Ideational and Thematic Approach}

Neoconservatism has no simple definition. Those who write about it adopt a number of approaches. Without doubt the most widely utilised approach is that which emphasises the ideological conversion experienced by neoconservatives in two distinct phases throughout the twentieth century. Neoconservatism is often defined first by the experience of the New York intellectuals who, following America's victory in World War Two, abandoned their flirtation with Trotskyism and by and large embraced liberal anticommunism. ${ }^{6}$ Second, neoconservatism is just as often defined through the experience of a group of disillusioned Democrats who, following America's defeat in Vietnam and the Democratic Party's subsequent embrace of McGovernism, ${ }^{7}$ abandoned the Democratic Party, left what they believed was a sullied and corrupted form of modern liberalism, and became intellectual foot soldiers in the Reagan revolution. ${ }^{8}$ Neoconservatism, in this narrative, is defined by the ideological conversion experienced by its leading intellectuals.

\footnotetext{
${ }^{6}$ For the dominant literature on the New York intellectuals, see Bloom, 1986; Dorman, 2000; Wald, 1987; and Wisse, 1986.

${ }^{7}$ This obviously refers to the Democratic Party's embrace of George McGovern in 1972, a candidate of the far left. The term is often used as a substitute for "isolationism."

${ }^{8}$ For the best analysis of this 1970s political migration, see Diamond, 1995: Ch. 9; Dorrien, 1993;

Ehrman, 1995; and Gerson, 1996.
} 
Those who have written an historical narrative emphasising this ideological conversion, including neoconservatives themselves such as Norman Podhoretz, have left behind a valuable resource for future researchers to consult, scrutinise, and rely on. ${ }^{9}$ Yet the definition's current relevance and utility should be questioned. Many of today's most influential neoconservatives such as William Kristol, Irving's son, have not undergone an ideological conversion, and have had little, if any, experience on the left. Moreover, when neoconservatism was spoken about throughout the Bush era, there was a tendency among academics to speak of it in a way which assumed it should be defined in a more thematic and ideational way. As this thesis demonstrates, there has been no shortage of ideas and general beliefs linked to neoconservatism. Yet not even those scholars who have shown some willingness to think about neoconservatism in terms of ideas and beliefs, including Francis Fukuyama and Steven Hurst, have explored them with the degree of thoroughness and accuracy they deserve. $^{10}$

When I travelled to Washington D.C. in early 2007 to conduct a number of interviews for this thesis, I began by asking the interviewees about definitions of neoconservatism. How, I asked, should one think of it? Should it continue to be thought of in terms of an ideological migration from left to right? Or should it be defined in a more ideational and thematic way, a way focussing on the ideas and beliefs of the community's leading foreign policy intellectuals? When I posed this question to Joshua Muravchik, one of the most prolific neoconservative foreign policy writers residing at the American Enterprise Institute, ${ }^{11}$ a think tank congenial to neoconservative ideas, he responded by saying that "The second definition makes a lot of sense except that no one has set out to define what those beliefs are." He added, "It makes more sense to define the neo-cons by a set of precepts about current politics, but that hasn't been done, at least authoritatively" (Muravchik, interview, 20 February 2007).

This, then, became the basis for this thesis. Over the course of the following chapters, I critically examine neoconservative ideas and beliefs in a way that illuminates the neoconservative approach to American foreign policy. The thesis

\footnotetext{
${ }^{9}$ Podhoretz has written prolifically on his ideological conversion. See Podhoretz, 1979; 1999; and 2000.

${ }^{10}$ As discussed above, the approaches and arguments of these two scholars are analysed in detail over the course of the first two chapters of this thesis.

${ }^{11}$ By early 2009, Muravchik was no longer a resident at the AEI.
} 
offers no simple definition of neoconservatism. Guided by the assumption that the traditional emphasis on the ideological conversion of first generation neoconservatives is no longer as germane as it once was, this thesis emphasises the importance of understanding neoconservatism through the ideas and beliefs of its leading foreign policy intellectuals.

Such an approach is not free from methodological difficulties, for neoconservatives, like all intellectual communities, are not always united when analysing the foreign policy issues of the day. They were by no means monolithic in their viewpoints when it came to the Balkans in the 1990s, Iraq in 2003, or the election of Barack Obama in 2008. The difficulty in generalising about neoconservative beliefs is best encapsulated by Irving Kristol's somewhat sardonic observation that "when two neoconservatives meet they are more likely to argue with one another than to confer or conspire" (Kristol, 1979a/1983: 75). In fact, there have been some neoconservatives who, after having flirted with neoconservatism at one point throughout their careers, suddenly retreated and embraced some of the tenets of an alternative paradigm. Take, for instance, the example of Daniel Patrick Moynihan, one of America's most distinguished public officials. As I show in a later chapter, Moynihan was an active participant in what has been called the neoconservative "war of ideology." 12 Yet by the mid-1980s, Moynihan had become a strong champion of international law, lambasting the Reagan administration for its "illegal" mining of Nicaraguan harbours. "A commitment to law," he argued in true Wilsonian fashion, "ought to be understood not as a commitment never to use force, but rather to use force only as an instrument of law" (Moynihan, 1984a/1988: 173).

Moynihan's renewed emphasis on the importance of international law was not the only fragment of evidence reflecting his growing estrangement from neoconservatism. In contrast to those neoconservatives who believed in the perdurability of communism, by 1984 Moynihan had declared "that the Soviet idea is spent," adding, "History is moving away from it with astounding speed" (Moynihan, 1984b/1988: 190). If Moynihan appeared to be moving towards a more liberal internationalist view on American foreign policy which prioritised international law and institutions, other neoconservatives such as Jeane Kirkpatrick and Irving Kristol wrote articles in the immediate aftermath of the Cold War which echoed the sentiments regularly

\footnotetext{
${ }^{12}$ Although I examine the neoconservative war of ideology shortly, see Dorrien, 1994: Ch. 3. This chapter documents the career of Irving Kristol and is entitled "The War of Ideology: Irving Kristol."
} 
expressed by foreign policy realists, emphasising the need for America to reduce its overseas commitments. With the demise of the Soviet Union, Kirkpatrick explained, America "will need to learn to be a power, not a superpower. We should prepare psychologically and economically for reversion to the status of a normal nation" (Kirkpatrick, 1990a).

The above arguments certainly pose considerable challenges to those who unqualifiedly stereotype neoconservatives as assertive unilateralists and messianic idealists. Yet the fact that some neoconservatives have occasionally made arguments so at odds with those in their intellectual community need not deter one from defining neoconservatism through the ideas and beliefs of its leading intellectuals. Ideas, after all, can evolve in a way that may at some point make them unrecognisable to their original authors and earliest devotees, a point even Irving Kristol acknowledges. "I am well aware," he once declared, "that the unanticipated consequences of ideas and acts are often very different from what was originally intended. That," he concluded, "is the basic conservative axiom, and it applies to conservatives as well as liberals and radicals" (Kristol, 1995/1999: 40). Although he was never the most authoritative neoconservative intellectual on American foreign policy, all neoconservatives inherited Irving Kristol's appreciation for the impact that ideas can have in politics. As the senior Kristol once argued,

The political ideas that men have always help to shape the political reality they live in - and this is so whether these be habitual opinions, tacit convictions, or explicit ideologies. It is ideas that establish and define in men's minds the categories of the politically possible and the politically impossible, the desirable and the undesirable, the tolerable and the intolerable (Kristol, 1970/1999: 325).

Kristol was by no means the only neoconservative to emphasise the importance and power of ideas. Although their careers followed a different path, Norman Podhoretz, the former influential editor of Commentary, the popular Jewish magazine that has popularised neoconservatism, shared Kristol's fascination with ideas and their consequences. In Ex-Friends: Falling Out with Allen Ginsberg, Lionel and Diana Trilling, Lillian Hellman, Hannah Arendt, and Norman Mailer (1999), Podhoretz recounts how he moved away from 1960s "radicalism," became repelled by the New Left and counterculture, and alienated many of his closest and most respected friends 
in the process. When explaining that even if one was to take into account the supporting cast of ex-friends in addition to the main cast listed in the subtitle of his book, Podhoretz states, "even adding all these to the main characters does not begin to exhaust the list of famous people whose friendship I have managed to lose or throw away in the past thirty years" (Podhoretz, 1999: 2).

Reading this volume, one cannot help but conclude that Podhoretz, while regretting the lost friendships, derives a certain amount of undisclosed pride in alienating so many of his former friends. The reason he could not maintain his friendships with his intellectual companions, Podhoretz tells the reader, is because an intellectual, a category in which he places himself, takes ideas so seriously that they simply cannot maintain cordial relations with even the closest of friends if their ideas clash. The intensity of an intellectual's affection for his/her ideas is said to preclude peaceful coexistence with other intellectuals hostile to those ideas. Podhoretz even compares an intellectual's attachment to their ideas to a religious believer's attachment to their faith, arguing,

We intellectuals are like that: not for nothing have we been called the 'clerisy' of a secular age, and not for nothing are we unable to live amicably together when disagreements arise over the ideas that are so vitally important to us" (Podhoretz, 1999: 7).

Neoconservatives, this thesis shows, constantly emphasise the importance of ideas and beliefs in international affairs. They take no ideas for granted and consider no beliefs to be without consequence. One must always be on guard both to safeguard the ideas worthy of protection and to detect the ideas considered subversive and deleterious. "The war of ideas," argues Mark Gerson in his thoughtful intellectual history on neoconservatism, "requires mandatory conscription; avoiding the draft will not make the war go away - it will merely make the side of the draft dodger lose" (Gerson, 1996: 352). Ideas, neoconservatives know, can drive men to acts of heroism and courage just as easily as they can drive men to commit ineffable crimes. "We are often told," Podhoretz argued in 1981,

that the Marxist-Leninist rhetoric of Third World leaders should not be taken seriously; all they really are is nationalists struggling to achieve independence and 
an identity of their own. But it was ideas - Communist ideas, some of them absorbed in the cafes of Paris - that turned Cambodia into the Auschwitz of Asia, that created a new Gulag in Communist Vietnam, that sent Cuban troops into Africa and the Middle East (Podhoretz, 1981: 41).

Neoconservatives believe that ideas rule the world. This is a core part of their belief system and the reason that every effort must be made to understand the ideas and beliefs of neoconservatives themselves. Each of the four chapters in the body of this thesis (Chapters 3-6) contains its own argument, and each of the chapters makes its own observations on neoconservatism. If the chapters were read in isolation from each other, one could easily come to the conclusion that there is not much separating neoconservatism from other theoretical paradigms and foreign policy approaches. Those well versed in IR theory will recognise assumptions neoconservatives share with liberal idealists, just as they will recognise assumptions neoconservatives share with foreign policy realists.

Yet neoconservatives are neither pure liberal idealists nor unqualified foreign policy realists. What follows, in fact, suggests that neoconservatives are more than a little unique. Robert Singh rightly argues, "neo-conservatism challenges idealism and realism alike, drawing on each while rejecting elements of both" (Singh, 2009: 64). By the time this thesis concludes, one may find an ironclad definition of neoconservatism as elusive as ever. Yet what this thesis offers is something no other volume on neoconservatism has attempted to achieve: a critical and detached engagement with the body of foreign policy ideas and beliefs which should define neoconservatism.

\section{Neoconservatives, the National Idea and the National Interest of America}

There are number of neoconservative ideas and beliefs this thesis examines. It is important, therefore, to briefly review the content of the following chapters in order to develop an appreciation for the direction in which this thesis is headed. One of the core neoconservative beliefs, one discussed extensively in Chapter 3, relates to the national idea of America. In discussions on American identity, it is often said that 
America has been founded upon a set of ideas, a creed, perhaps even an ideology. ${ }^{13}$ When historians, commentators, and scholars make this argument, they invariably emphasise the universal applicability of American ideals and values. "The United States," observed Gordon Wood, one of America's great historians, "was founded on a set of beliefs and not, as were other nations, on a common ethnicity, language, or religion" (Wood, 2006: 4). As such, anyone, at least in terms of belief systems, is entitled to become a citizen of America. "Being an American," Seymour Martin Lipset explained, "is an ideological commitment. It is not a matter of birth. Those who reject American values are un-American" (Lipset, 1997: 31).

While scholars have identified a number of influences shaping American political culture, they are by no means united when it comes to agreeing on which of these influences has been greatest. ${ }^{14}$ However, there is a core American idea that neoconservatives aspire to protect. The idea of natural rights and human rights is, so to speak, the national idea of America. ${ }^{15}$ It was an idea promoted at the philosophical level by Enlightenment thinkers such as John Locke; it was an idea appropriated and eloquently articulated by the authors of America's Declaration of Independence; and it was an idea forcefully reasserted and vindicated by Abraham Lincoln throughout America's Civil War. ${ }^{16}$ Americans, to be sure, may not have invented the natural rights philosophy, but they did, as Michael Zuckert points out, make "the most explicit and thoroughgoing commitment to that philosophy that had yet been carried out in practice anywhere" (Zuckert, 2001: 5).

\footnotetext{
${ }^{13}$ There is, as one would expect, a large amount of literature which has examined aspects of American exceptionalism. Without doubt the two most frequently cited contributions include Hartz, 1955; and Hofstadter, 1948. For more recent studies, one should consult Huntington, 2005; Ignatieff, 2005; and Lipset, 1996. Even this relatively small sampling will introduce the reader to a diverse range of perspectives that have attempted to identify what makes America unique.

${ }^{14}$ For an interpretation which emphasises the religious influence on American politics and culture, see Morone, 2004.

${ }^{15}$ The claims I make in this paragraph are reinforced by the work of Michael Zuckert. Zuckert is one of the leading scholarly authorities on the thought of John Locke and its influence on the American founding. Zuckert's book, The Natural Rights Republic (2001), is one of the most sophisticated attempts to show how America's natural rights liberalism has dominated American political culture. Although not denying that other traditions have also influenced American political culture, Zuckert sees the success and uniqueness of America as being built upon the capacity of its natural rights liberalism to absorb these other traditions within the dominant natural rights philosophy underlying the American regime. For a defence of the assertions made in this paragraph, a greater analysis of the rights spoken of in the Declaration of Independence, and an elaboration on these and similar themes, see Zuckert, 1998; 2001; and 2002.

${ }^{16}$ For one of the finest scholarly analyses of what was at stake in the American Civil War, especially in the realm of ideas, see Jaffa, 1959; and 2004. The first volume dissects Lincoln's battles with his rival Stephen Douglas and his popular sovereignty doctrine. The second dissects the Lincolnian challenge to John Calhoun's positive good theory of slavery.
} 
The core of the natural rights philosophy is quite simple: government exists, this philosophy holds, to secure inalienable human rights. Jeane Kirkpatrick, one of the most thoughtful neoconservative foreign policy intellectuals whose work I examine in the following pages, put it best: "The American people are defined by the American creed," she argued. "The vision of the public good which defines us is and always has been a conviction that government exists, above all, for the purpose of protecting individual rights" (Kirkpatrick, 1981: 42). It is this idea, I argue, that neoconservatives seek to protect. And it is for this reason that Chapter 3 commits itself to the most thorough examination of the ways in which this idea has been protected by neoconservatives.

This argument is of some significance. As I demonstrate in the following chapter, there has been a considerable amount of scholarly effort expended trying to deAmericanise neoconservatism. A number of scholars have attempted to place neoconservatism outside "mainstream" American foreign policy traditions, none more so than those scholars who emphasise the purported links between neoconservatives and Leo Strauss, a professor of political philosophy whose obscure teachings have aroused such fascination in recent times.

Yet in the realm of American foreign policy, neoconservatives, I argue, are very much a product of modernity and its liberal assumptions. In fact, neoconservatives consider the preservation of the national idea to be a vital national interest of the United States. They do not take the idea for granted and they do not assume that it will always prevail against rival ideas embedded in hostile ideologies. Although the "national interest" itself is a term often used to describe the minimal national goals of survival and security, there is no reason why such a term should not be taken to refer to less concrete national priorities and goals. Individuals, like nations, have proven themselves to be more than willing to sacrifice for an idea, for an identity, for a religious faith, and for immortal glory. IR theorist Henry Nau even argues that a perception that a nation has of itself determines its chances of survival. Without "a unified and healthy self-image," Nau argues, "a nation has no incentive to accumulate or use material power. It cannot defend its national interests; indeed, it may disintegrate" - witness the Soviet Union (Nau, 2002: 4).

What I examine in Chapter 3 is a less concrete national interest. A core part of the neoconservative belief system is the assumption that the national idea's vitality is not assured. If it is to be preserved, it must be constantly defended and constantly 
advanced. Developing an appreciation for the neoconservative approach to American foreign policy requires developing an appreciation for the lengths to which neoconservatives have gone in order to undercut the arguments and ideas believed to threaten the national idea of America. The attempt to protect the national idea is not free from ambiguity, but it is a core part of the neoconservative approach to American foreign policy. And if neoconservatism is to be defined by the ideas and beliefs of its leading foreign policy intellectuals, then there is no doubt that the attempt made by neoconservatives to act as the vigilant guardians of the national idea constitutes a very important part of that definition.

\section{$\underline{\text { Neoconservatism and the War of Ideology }}$}

When Gary Dorrien released his first volume on neoconservatism, The Neoconservative Mind: Politics, Culture and the War of Ideology (1993), he placed considerable emphasis on the latter part of his subtitle, "the war of ideology." It was also the title of the chapter in his first volume documenting the career of Irving Kristol. It is for good reason that Dorrien emphasised the importance of the neoconservative war of ideology. Ideology, neoconservatives believe, should remain an inextinguishable part of modern politics. As Irving Kristol put it, "in the modern world, a non-ideological politics is a politics disarmed" (Kristol, 1983: ix). One could not escape ideology even if one wished to, Kristol argued. It was, he explained, the American and French revolutions "which ushered in the ideological era of politics" (Kristol, 1983: ix). These were the revolutions said to make ideology a permanent feature of the contemporary world.

The war of ideology, I argue in Chapter 4, is a defining feature of the neoconservative approach to American foreign policy. This is as true for neoconservatives who have written most prolifically throughout the war on terror as it was true for the neoconservatives who made their intellectual contributions throughout the Cold War. Many scholars who have written about neoconservatism emphasise the importance neoconservatives attach to the character of regimes. For neoconservatives, Singh argues, "The domestic character of regimes has a major effect on their external activities, whether in terms of aggressive behaviour towards other states (Saddam's Iraq, post-1979 Iran) or repression of their own people" (Singh, 2009: 64). Francis Fukuyama agrees. One of the "common principles" 
running through neoconservative "thought up through the end of the Cold War," Fukuyama argues, was "a concern with democracy, human rights, and more generally the internal politics of states" (Fukuyama, 2006: 4).

Such arguments, I explain, understate the degree to which the neoconservative war of ideology is responsible for leading neoconservatives to embrace this principle. The belief that the internal nature of regimes affects their external behaviour is quite valid, but for neoconservatives there has never been any searching and exhaustive analysis of why this is so. It is an unexamined article of faith, one which is subscribed to because of the importance neoconservatives attach to standing up for American values around the world. It is an IR principle neoconservatives support because it provides a patina of theoretical sophistication to their messianic and nationalistic impulses. It is America's mission, they believe, to engage in ideological combat. American policy-makers, according to neoconservatives, should not only adopt an ideologically inspired foreign policy, but should assume that other states and movements are driven by their own ideological drives and ambitions, making the reconciliation of interests a fanciful mirage if not a pernicious delusion.

In Chapter 4, I critically examine the foreign policy consequences of the neoconservative war of ideology, both throughout the Cold War and the war on terror. The chapter makes a number of arguments. Neoconservatives, I explain, are not the faithful heirs of the Reagan legacy. They constantly underestimated Ronald Reagan and his capacity to transcend the Cold War. Their emphasis on the importance of ideology in international affairs precluded them from even contemplating that national leaders could make a difference in mitigating superpower anxieties. This war of ideology, I argue, also put them at odds with some of the implications of Francis Fukuyama's “end of history" thesis, and eventually led to their post-September 11 advocacy of democratising the Middle East.

Although there have been a number of sophisticated studies on what ideology is, ${ }^{17}$ when neoconservatives speak about ideology they speak about it in terms of political systems. When distinguishing between the reasons why segments of the American right opposed Soviet communism, Norman Podhoretz was quick to explain the basis of his opposition:

\footnotetext{
${ }^{17}$ For arguably one of the most definitive examinations of "ideology" and the way in which it should be conceived, see Freeden, 1998. For a study emphasising the impact of ideology on IR, see Cassels, 1996.
} 
What in my view separated us from them was that we were free and they were not, that our political system was democratic and that theirs was totalitarian. And I consistently maintained that liberal democracy was itself a value - a value that Americans wanted to live by and that they were even willing to die for (Podhoretz, 1979: 27).

This is arguably one of the clearest expressions of what Anatol Lieven would call America's "civic nationalism" (see Lieven, 2004: Ch. 2). Faith in the American creed, according to neoconservatives, is not enough; it must lead to an activist foreign policy committed to defeating America's ideological competitors, at the risk, if need be, of American lives.

In many ways, neoconservatives have been most comfortable when they have had an ideological competitor against which they could define themselves. In 1996, Podhoretz wrote an article in which he argued that neoconservatism "is dead - by which, reverting from metaphor to straightforward denotation, I mean quite simply that it no longer exists as a distinctive phenomenon requiring a special name of its own" (Podhoretz, 1996: 19). “Once upon a time," Podhoretz noted when discussing neoconservatism and American foreign policy, "I could foresee with reasonable assurance where any neoconservative would stand on almost any serious issue in world affairs. Today," he regretfully concluded, "I am hard put to predict where even some of my closest friends will come out when a contentious issue like Bosnia arises" (Podhoretz, 1996: 24). Although Podhoretz celebrated the demise of the Soviet Union and believed the disintegration of the Soviet empire vindicated neoconservative foreign policy recommendations, without an ideological competitor against which neoconservatism could define itself, Podhoretz was clearly lost.

Ironically, in his isolation he was not alone. Although tending to gravitate towards the view that America should reduce its overseas commitments in the immediate aftermath of the Cold War, Irving Kristol was even more candid in regretting the absence of an ideological competitor. "With the end of the Cold War," he stated,

what we really need is an obvious ideological and threatening enemy, one worthy of our mettle, one that can unite us in opposition. Isn't that what the most 
successful movie of the year, Independence Day, is telling us? Where are our aliens when we most need them?" (Kristol, 1996).

As this quote attests, the war of ideology has been an enduring feature of the neoconservative approach to American foreign policy. Throughout the Cold War, neoconservatives relentlessly waged their brand of ideological combat at the United Nations, in the American Congress, and on the pages of the nation's newspapers, magazines, and journals. Defining neoconservatism through the ideas and beliefs of its adherents requires a thorough examination of the neoconservative belief in the necessity and desirability of ideological conflict. In Chapter 4 , I provide this examination. Throughout this chapter, I argue that the neoconservative war of ideology led to problematic policy recommendations not only throughout the Cold War, but also, to borrow Kristol's terminology, after those "aliens" finally made their appearance on September 11, 2001.

\section{Neoconservatism, Great Power War, and American Military Preponderance}

If chapters 3 and 4 focus on some of the more idealistic elements of neoconservatism, chapters 5 and 6 focus more on the importance neoconservatives attach to American power. Neoconservatives do not consider themselves utopian idealists. They believe that America must accumulate power and they believe that America must unhesitatingly use it when the need arises. Only American power, they argue, can preserve order in the world. Of course, no problem of international politics arouses as much scholarly debate and inquiry as the problem of order. "The central problem of international relations," explains John Ikenberry, one of America's most distinguished liberal internationalists, "is the problem of order - how it is devised, how it breaks down, and how it is recreated" (Ikenberry, 2001: 22). Hedley Bull, arguably Australia's most accomplished IR theorist, wrote the seminal text on the topic, The Anarchical Society: A Study of Order in World Politics (1977). It is a book in which Bull distinguishes between world order and international order, asks whether the dictates of justice can be reconciled with the requirements of order, and identifies and explores what he describes as the "institutions" of order.

While Bull's text remains one of the most authoritative, scholars who discuss the question of order are invariably driven by the question of what causes, and perhaps 
more importantly, what prevents the outbreak of great power war. Some stress the role played by material factors (usually realists), emphasising the impact of varying distributions of power in the international system (unipolar, bipolar, tripolar, multipolar); ${ }^{18}$ others will emphasise the importance of the internal properties of states (usually liberal IR theorists who draw attention to the importance of regime type and what is often called "the democratic peace thesis"); ${ }^{19}$ and others still will speak about the importance and value of globalisation, the liberal international economic order, and the pacifying effects of regional and global institutions. ${ }^{20}$

For neoconservatives, it is the role America plays in the preservation of order that is the key explanation for today's relatively benign international environment. No idea, I explain in the following chapter, has been so regularly attached to neoconservatism than the idea that only overwhelming American military preponderance can prevent a return to global disorder. Yet those who make this link, I demonstrate, rarely examine the continuity between neoconservative ideas circulated throughout the Cold War and post-Cold War eras. Neoconservative support for a unipolar international order had its roots in the critiques neoconservatives levelled at the Nixon-Kissinger administration's pursuit of détente with the Soviet Union. This support, in other words, was not a post-Cold War phenomenon. If neoconservatism is to be defined by the beliefs and ideas of its leading foreign policy intellectuals, then every effort must be made to understand the roots of these beliefs and ideas. This is a crucial dimension of any project aiming to understand the evolution of the worldview of its subjects.

At the heart of neoconservative support for a unipolar international order has been a profound scepticism about the stability of a balance of power international system. Such scepticism has deep roots in the American psyche. It was, after all, Henry

\footnotetext{
${ }^{18}$ This was surely one of the great debates in the immediate aftermath of the Cold War. IR scholars endlessly debated both the desirability and durability of a unipolar international order. For a sampling of the arguments of those who expressed a degree of scepticism about the vitality of the American hegemon, and identified the rise of other powers as a key challenge to American primacy, see Huntington, 1999; Kupchan, 1998; 2003: Ch. 4; Layne, 1993; 2006a; Mearsheimer, 1990; 2003: Ch. 9; and Waltz, 1993. For a sampling of the arguments of those who emphasise the likely persistence of U.S. primacy, see Brooks and Wohlforth, 2002; Lieber, 2005; and Wohlforth, 1999. For two good studies with a collection of essays analysing these questions, see Ikenberry (ed.), 2002; and Kapstein and Mastanduno (eds.), 1999.

${ }^{19}$ Although I will draw attention to this literature when I examine the neoconservative war of ideology, for a useful introduction into the debates centring upon the "democratic peace thesis," see Brown, M. Lynn-Jones, S. and Miller, S. (eds.), 1996.

${ }^{20}$ For an examination of some of the benefits of globalisation, see Bhagwati, 2004. For a look at the positive role institutions can play in the preservation of order, see Ikenberry, 2001; and Keohane, 1984.
} 
Kissinger, the target of many neoconservative criticisms throughout the 1970s, who lamented the unwillingness of America to abide by the dictates of balance of power logic. "At no time in its history," Kissinger regretfully concluded, "has America participated in a balance-of-power system" (Kissinger, 1994: 22). When Woodrow Wilson went to Paris following the wreckage of World War One, he spoke of forging a "community of power," telling audiences that the balance of power "was forever discredited as a way to keep peace" (see Macmillan, 2003: 13). After World War Two, according to Melvyn Leffler, American policy-makers forged ahead with their plans of achieving a preponderance of power (see Leffler, 1992).

Of course, as I explain in Chapter 5, there are differences, some of them quite palpable, between neoconservative unipolarists and earlier generations of American foreign policy thinkers. But this should not obscure the central purpose of this chapter. Neoconservatives, I argue, have consistently questioned the value of a balance of power international system. Throughout the Cold War, they argued that the presence of a revolutionary global superpower - the Soviet Union - imperilled the stability of the international system, making the presence of a preponderant America vital to the future security of the world. After the Cold War ended, neoconservatives did not abandon their support for perpetuating American preponderance. Since the presence of the Soviet Union could no longer justify exorbitant defence expenditures, neoconservatives began to emphasise the dangers of a return to a world in which multiple great powers existed. Such an argument found its clearest expression in the 1992 Defense Planning Guidance (DPG) and the 1993 Regional Defense Strategy (RDS), two documents I examine in detail.

Irrespective of the way in which neoconservatives defined threats, they often arrived at the same conclusion: that American military preponderance is good for America, and good for the world. Neoconservatives have been nothing if not consistent in their belief that only overwhelming American military preponderance can prevent the outbreak of great power war. This, in fact, is the strategic logic underlying many of the arguments made in the documents cited above. It is a form of strategic logic which is often underemphasised in the literature. Gary Dorrien's second volume on neoconservatism, Imperial Designs: Neoconservatism and the New Pax-Americana (2004), a book strongly emphasising the neoconservative quest to perpetuate America's military preponderance, is entirely lacking in any assessment of the strategic logic buttressing neoconservatism's calls for preserving a unipolar 
international order. Yet the belief that multipolar international orders lead to great power war has been a staple of neoconservative thinking for many years. It was a belief every bit as influential throughout the Cold War as it was throughout the 1990s.

\section{$\underline{\text { Neoconservatism and American Power }}$}

Coupled with their quest to perpetuate American military preponderance, neoconservatives advocate a highly militarized foreign policy which calls for vigorous displays of American power. This, I argue in Chapter 6, is a key feature of the neoconservative approach to American foreign policy, a feature which no doubt contributed to their support for the 2003 Iraq War. Following America's defeat in Vietnam, neoconservatives attempted to reunite American power with American virtue. This is what political theorist John Kane calls "the persistent moral dilemma" of American foreign policy. He explains, "An enduring article of American faith prescribes both that power be used only for virtuous ends and that American virtue not be sullied in the exercise of power" (Kane, 2008: 2).

After experiencing defeat in Vietnam, Americans became less confident in the morality and efficacy of their nation's power. American power, in short, became less usable. Nothing offended neoconservatives more, though, than the notion that American power no longer had an important role to play in the world. In addition to spending decades attempting to re-moralise American power, reuniting American virtue with American power, neoconservatives spent just as long attempting to enhance the efficacy of America's military might. Neoconservative beliefs on American power, I argue in Chapter 6, culminated in the adoption of the idea of preventive war. Once embraced, this idea was not easily controlled. It was the central idea giving legitimacy to the 2003 Iraq War and it was the central idea giving credence to neoconservative calls to attack Iran's nuclear facilities throughout the concluding days of the Bush presidency. As important as neoconservatives believe it is to perpetuate America's military preponderance, they do not wish to hoard that power for troubled times; they wish to use it, believing a vigorous display of American power will ward off dangers.

Although there have been no shortage of studies on American militarism in recent years, it must be noted that neoconservatives were not advocating a series of preventive wars on the eve of the Bush presidency; they believed in American power, 
to be sure, but their belief in the idea of preventive war was articulated with vigour only after September $11 .^{21}$ This is not to say that their beliefs in relation to the indispensability of American power did not predispose them to adopt this idea so enthusiastically after these attacks any more than it is to deny that there is something more than a little unsettling about the ease with which they advocate the employment of American power. Neoconservatives had long thought about Iraq, frequently discussing ways in which Saddam Hussein could be toppled. ${ }^{22}$

It is, though, to make the plausible, if empirically unverifiable, suggestion that the terrorist attacks on September 11,2001, had as much of an emotional impact on neoconservatives as they did on the rest of America. After these attacks, there was an additional urgency in neoconservative writings. The sheer brazenness of the terrorist assaults could not but influence any observer of the events of that day. As one expert on religious violence explained,

The very adjectives used to describe acts of religious terrorism - symbolic, dramatic, theatrical - suggest that we look at them not as tactics but as performance violence. The spectacular assaults of September 11, 2001 were not only tragic acts of violence; they were also spectacular theatre (Juergensmeyer, 2003: 126).

As an intellectual community which prides itself on its adroitness for detecting existing dangers in the world, there was no greater confirmation of the presence of those dangers than in the "spectacular theatre" performed most brutally by al-Qaeda on September 11. After the attacks, neoconservatives became the strongest supporters of wielding American power in the post-September 11 world - for revenge, for justice, for America's future security. Yet their arguments went even further than that. After years of warning about unforeseen perils that would only manifest

\footnotetext{
${ }^{21}$ For some of the most prominent studies on American militarism, see Bacevich, 2005; Chomsky, 2004; and Johnson, 2004.

${ }^{22}$ In 1998, the Project for a New American Century, an organisation I will discuss shortly, sent President Clinton a letter, advising him that a change of strategy was needed. "The only acceptable strategy," it warned, "is one that eliminates the possibility that Iraq will be able to use or threaten to use weapons of mass destruction. In the near term, this means a willingness to undertake military action as diplomacy is clearly failing. In the long term, it means removing Saddam Hussein and his regime from power. That now needs to become the aim of American foreign policy" (Letter to President Clinton on Iraq, 1998). For a further discussion among neoconservatives on how to dislodge Saddam throughout the 1990s, see Kagan, 1998; and Khalilzad and Wolfowitz, 1998.
} 
themselves with the passage of time, neoconservative faith in American power reached its zenith throughout the Bush era. The groundwork, I argue, had certainly been laid years before, but after the terrorist attacks on September 11, neoconservatives became, if possible, even more immovable in their conviction that only American power could defend the "free world." The evolution of neoconservative beliefs on American power, therefore, is an important part of this study and must feature prominently in any thematic examination on the neoconservative approach to American foreign policy.

\section{The Argument Restated}

The above summaries of the chapters to follow do not provide an exhaustive analysis of the arguments I make in each of these chapters. They are, though, an accurate indication of the content covered in the body of this thesis. As previously stated, each of these chapters makes its own observations on the neoconservative approach to American foreign policy. Although neoconservatism is not easily defined, it can be demystified. By critically engaging with the ideas and beliefs of the community's intellectual figureheads, one approaches a more apt definition of neoconservatism. Irving Kristol once called neoconservatism a "persuasion;" Norman Podhoretz once called it a "tendency" (Kristol, 1979a/1983; Podhoretz, 1996: 20). Each definition suggests that neoconservatism is best thought of as a "mindset," a way of thinking, perhaps a melange of inclinations.

Yet it would be a mistake to assume that one could not define neoconservatism through the ideas and beliefs of its leading foreign policy intellectuals. Despite their repeated arguments that they do not constitute a conspiring monolith, neoconservatives are much closer in their general views than their qualifications suggest. Even Irving Kristol has acknowledged that "neoconservatives may disagree with this emphasis or that - we are in no way a coherent, organized movement - but I should be surprised if those disagreements were more than marginal" (Kristol 1983: $\mathrm{xv}$ ). There is, in fact, a considerable amount of ideational continuity running through neoconservative writings throughout the Cold War and the war on terror. There are occasional policy differences, to be sure, but they are not fundamental differences, preventing one from thinking about neoconservatism in terms of ideas and beliefs. On the big questions examined in this thesis, neoconservatives are often of one mind. 
$\underline{\text { Methodology - Ideas and Neoconservatism }}$

Neoconservatism should remain a serious candidate for scholarly inquiry for a number of reasons. Most importantly, the influence neoconservatives believe that ideas can have in the world must encourage the intellectual community to scrutinise the ideas and beliefs of neoconservatives themselves. Admittedly, most disciplines and fields of study contend with what political scientists call the "structure/agency" problem of political science. Should scholars, it is often asked, focus on the impersonal structures which can both limit and widen the sphere of available options for policy-makers? Or should they focus more on the personal properties of agents, their belief systems, their values, their worldviews? A lively political science literature has emerged which analyses these questions. ${ }^{23}$ Although this thesis heavily emphasises the importance of ideas and beliefs, it does not diminish the importance of structure or deny its relevance. After all, ideas do not explain everything. As Steven Hurst rightly argued in 2005 ,

The ideas that are shaping the Bush foreign policy now have been around and held by individuals for decades. The key question is why they are marginalized at one time and shaping government policy at another. The key explanatory variables, therefore, actually lie outside the realm of ideas (Hurst, 2005: 76).

Yet even if one accepts the premise that structure can determine which ideas prevail at a given time, ideas retain considerable importance. First, clarity about ideas and beliefs is pivotal. One cannot say anything about the degree to which ideas have influenced policy unless one has some understanding of the content of the ideas themselves. ${ }^{24}$ "Structures," as political scientist Mark Blyth put it in the title of one paper, "do not come with an instruction sheet" (Blythe, 2003). Ideas can impose

\footnotetext{
${ }^{23}$ For an excellent discussion on the growing emphasis being placed on ideas within the discipline of IR, see Blyth, 2003. For a collected volume of essays which look at the impact ideas have on policy outcomes and how they interact with structure, see Goldstein \& Keohane (editors), 1993. For a volume which deals directly with the structure/agency question and examines the competing ontologies of all IR theories, see Wight, 2006. For two additional articles emphasising the importance of ideas in international affairs, see Desch, 1998; and Flibbert, 2006.

${ }^{24}$ This is a point that even Hurst concedes as he dissects a number of conflicting ideas which are said to undermine the claims of those who have argued that neoconservative ideas had a decisive impact on the Bush administration's approach to American foreign policy. Although I will return to this article shortly and examine its contents in greater detail, see Hurst, 2005: 76.
} 
meaning on events and shape responses. Ideas, Judith Goldstein and Robert Keohane argue, "help to order the world" (Goldstein \& Keohane, 1993: 12). "By ordering the world," they explain, "ideas may shape agendas, which can profoundly shape outcomes" (Goldstein \& Keohane, 1993: 12).

So much of the commentary on the rise of neoconservatism has wrestled with the question of influence. How much influence, authors debate, did neoconservatives have over the Bush administration's foreign policy? Were they the true architects of the Iraq War, tucked away in the lower rungs of the Pentagon and Vice President's office, eagerly gathering “evidence” of Saddam's WMD programs and links to alQaeda? ${ }^{25}$ Or has their influence been drastically overstated? Were not George W. Bush, Dick Cheney, Condoleezza Rice, and Donald Rumsfeld, towering personalities who had little need of outside guidance? ${ }^{26}$ Were they not a collection of Jacksonian nationalists and foreign policy realists? ${ }^{27}$

These are the questions which will be wrestled with for a number of years. Although this thesis is not directly taking up the question of influence, it is guided by the assumption that neoconservatives did have some measure of influence over the Bush administration's approach to American foreign policy, especially throughout the administration's first-term and after September 11. How that influence should be measured will be a bone of contention among academics and historians for some time to come. Influence, after all, comes in a variety of forms. ${ }^{28}$ Even if no neoconservative - not Paul Wolfowitz, not Douglas Feith, not Richard Perle persuaded President Bush to go to war against Saddam Hussein's Iraq in March 2003, policies still need to be marketed, explained, and rationalised. It is here, I believe, that neoconservatives played the most consequential of roles.

This thesis, in other words, is not an interpretive history on the Bush administration's approach to American foreign policy. Nor is it an examination of any one neoconservative and the influence he may or may not have had on the conduct of American foreign policy throughout this period. In his thoughtful examination on the intellectual contributions made by a number of foreign policy

\footnotetext{
${ }^{25}$ For an introduction into this line of thought, see Hersh, 2004: 207-224; Packer, 2005: 104-110; and Singer, 2004: 260-265.

${ }^{26}$ For an excellent history of Bush's war cabinet, see Mann, 2004.

${ }^{27}$ For an examination of the alleged differences between conservative nationalists such as Dick Cheney and President Bush, and neoconservatives, see Hurst, 2005. For an excellent analysis of the Jacksonian approach to American foreign policy, see Mead, 2002: Ch. 7.

${ }^{28}$ For a thoughtful discussion on neoconservative influence, see Hirst, 2009.
} 
thinkers in twentieth century America, H.W. Brands defended the approach he adopted by emphasising the need for greater engagement between scholars of American foreign policy and the intellectuals and practitioners who have aspired to shape it. "Histories of American foreign policy," he explained, "are legion; histories of the intellectual precursors of policy are far rarer" (Brands, 1998: ix). In a similar spirit, throughout this thesis I emphasise and explore the "intellectual precursors of policy." The question of neoconservative influence has been addressed by others; it is not one this thesis aspires to answer, at least not definitively.

Instead, by emphasising the importance of neoconservative ideas and beliefs, one adopts one of the key assumptions of neoconservatives, namely, that ideas have a big impact in the world, especially in the world of international politics. It is an assumption which led one prominent IR theorist to emphasise a point of convergence between neoconservatism and social constructivism, one of the most prominent paradigms in IR theory. "If, for example, the most basic claim of social constructivism is that 'ideas matter' in international politics," Michael Williams argues, "it is one that neoconservatives would heartily endorse." (Williams, 2005: 327). Certainly Irving Kristol's observation that "ideas rule the world because even interests are defined by ideas" finds an echo in Alexander Wendt's claim "that the meaning of power and the content of interests are largely a function of ideas" (Kristol cited in Heilbrunn, 2008: 161; Wendt, 1999: 96).

Yet neoconservatives themselves, it must be acknowledged, are not overly interested in the abstract theoretical discussions which dominate the pages of leading scholarly journals. Nor are they overly concerned with those inscrutable debates taking place in overcrowded seminar rooms populated by aging and quarrelsome academics. Rather, "it is the self-imposed assignment of neoconservatism," Irving Kristol once asserted, "to explain to the American people why they are right, and to the intellectuals why they are wrong" (Kristol, 1983: xv). The ideas neoconservatives are interested in are those that can change the world. It is not uncommon to hear neoconservatives express admiration for the degree to which their communist adversaries of yesteryear understood the power and influence of ideas. "Understanding the relationship between ideas and power was the essence of Lenin's genius," Joshua Muravchik argued (Muravchik, 1991: 3). America, neoconservatives believe, needs to imitate its erstwhile communist adversaries, at least in terms of recognising the sway that ideas can have over the minds of men. "Ironically we 
Americans, who possess a profound and successful idea," Muravchik lamented, "have rarely understood the potency of ideas, while the communists, who possess a false and failed idea, have understood it quite thoroughly" (Muravchik, 1991: 2).

Neoconservatives are public intellectuals. Regardless of whether they have been successful, they certainly wish to see their ideas applied in the world and incorporated into government policy. They have spent many years creating a number of advocacy organizations with the intent of influencing the direction of American politics. In the early 1970s, they set up the Coalition for a Democratic Majority, an organisation dedicated to rescuing the Democratic Party from McGovernism and the far left. ${ }^{29}$ When that project failed, they established the Committee on the Present Danger, an advocacy organisation which assisted Ronald Reagan to arrest the loss of faith in American power. ${ }^{30}$ Some years after the fall of the Soviet Union, neoconservatives established the Project for a New American Century (PNAC), ${ }^{31}$ an organisation which established a network of likeminded thinkers who crafted an assertive role for America in the post-Cold War world. ${ }^{32}$ Under the stewardship of William Kristol and Robert Kagan, this latter organization frequently wrote letters signed by an array of foreign policy intellectuals to sitting presidents, instructing them on matters of foreign policy. Throughout the 1990s, one letter was sent to President Clinton, encouraging him to topple Slobodan Milosevic, the dictator who wrought havoc in the Balkans. ${ }^{33}$ After September 11, it was President Bush who received a letter signed by a number of members of the Project for a New American Century, a letter advising him on the way in which the war on terror should be conducted. ${ }^{34}$

\footnotetext{
${ }^{29}$ For a good overview of the Coalition for a Democratic Majority's attempts to wrest the Democratic Party away from McGovernism, see Diamond, 1995: Ch. 9.

${ }^{30}$ For the most comprehensive overview of the Committee on the Present Danger and its attempts to elevate Reagan to the presidency, see Sanders, 1983.

${ }^{31}$ The Project for a New American Century was created in 1997 and dissolved in 2006.

${ }^{32}$ For a sophisticated discussion on the influence of The Project for a New American Century, see Abelson, 2006: Ch. 9.

${ }^{33}$ Although I draw attention to this letter in a later chapter, the letter concluded, "Mr. President, we are under no illusion that the steps we recommend are easy or guarantee success. We are certain, however, that after seven years of aggression and genocide in the Balkans, the removal of Milosevic provides the only genuine possibility of a durable peace" (Letter to President Clinton on Milosevic, 1998).

${ }^{34}$ Although the letter was sent under the name of William Kristol, it was signed by many members of the Project for a New American Century and many prominent neoconservatives. It was this letter that called explicitly for the toppling of Saddam Hussein. In it, the signatories endorsed the recommendation that "even if evidence does not link Iraq directly to the attack, any strategy aiming at the eradication of terrorism and its sponsors must include a determined effort to remove Saddam Hussein from power in Iraq" (Letter to President Bush on the war on terrorism, 2001).
} 
Yet it was not only policy-makers neoconservatives sought to influence. Stephen Halper's and Jonathan Clarke's America Alone: The Neoconservatives and the Global Order (2004) extensively documents the attempts of neoconservatives to dominate "the political discourse" in the United States. Not only did they court the cable news networks, Fox News prominent among them, and forge ties with segments of the evangelical right, but they successfully established themselves within the vast array of think tanks and institutes churning out position papers. ${ }^{35}$ These were papers which, it was hoped, would shape policy. Halper and Clarke argue,

The American Enterprise Institute, the Heritage Foundation, the Jewish Institute for National Security Affairs (JINSA), the Center for Security Policy (CSP), the Hudson Institute, and the PNAC had also become important elements in a neoconservative coalition of intellectuals, ex-government officials, political advisers, media figures, and key conservative personalities, all pressing for the era of American supremacy. They spoke at congressional hearings, took an active role in the mainstream media discourse, sent open letters to the White House, published articles regularly in the major newspapers, and produced a stream of books (Halper \& Clarke, 2004:103).

Therefore, if there is a debate over the degree to which neoconservatives shaped the Bush administration's foreign policy post-September 11, there should be little debate over their attempts to do so. Neoconservatives themselves often sounded euphoric in the earliest moments of the Bush presidency over the degree to which their ideas were being incorporated into policy. "The President of the United States, on issue after issue," exclaimed Richard Perle before his subsequent disavowals, "has reflected the thinking of neoconservatives" (Perle, 2005). ${ }^{36}$

In addition to their attempts to influence policy, neoconservatives seek to create a climate of public opinion favourable to their ideas, one that policy-makers cannot ignore. They would warmly endorse Abraham Lincoln's observation that "he who moulds public sentiment goes deeper than he who enacts statutes or pronounces

\footnotetext{
${ }^{35}$ On neoconservative attempts to forge connections with the religious right and segments of the U.S. media, see Clarke \& Halper, 2004: Ch. 6.

${ }^{36}$ By the end of 2006, after security in Iraq continued to deteriorate, Perle was no longer as willing to claim that neoconservatives had much influence in the Bush administration. For the interview with David Rose of Vanity Fair in which Perle makes this argument, see Rose, 2006.
} 
decisions. He makes statutes and decisions possible or impossible to be executed" (Lincoln, 1854/2004: 55). In many ways, "moulding public sentiment" is a task more important than occasionally shaping policy. Without a public sentiment supportive of and capable of sustaining a democracy's foreign policy, there will be very real limitations to what can be achieved in the world. Neoconservatives recognise this. In 2009 , their ideas may not be as appealing as they were in 2002, but this recognition still necessitates a critical engagement with their ideas and beliefs. After all, there is a scintilla of truth to the claim that ideas often outlive their authors. They may momentarily lose their allure, but they are always present, simmering below the surface, capable of being refined, waiting to be mobilised.

\section{Neoconservatism - Who's In and Who's Out?}

If neoconservatism is difficult to define, it is just as difficult to determine who should be identified as a "neoconservative." As Halper and Clarke argue, "There is no absolute dividing line between who is and who is not a neo-conservative" (Halper, 2004: 10). This dilemma often becomes entangled with the question of neoconservative influence over the Bush administration. Those discussed throughout this thesis, though, tend to be those discussed most frequently in the dominant literature on neoconservatism, perhaps with one important qualification. ${ }^{37}$ Even a study of this magnitude cannot dissect the contributions of every thinker and policymaker identified as a neoconservative. Therefore, I emphasise and explore the contributions of neoconservative intellectuals more than I do the contributions of those who have spent greater amounts of time in policy-making positions. John Bolton, Douglas Feith, and Elliot Abrams are respectfully overlooked while the intellectual contributions of Norman Podhoretz, Jeane Kirkpatrick, William Kristol, Robert Kagan, Joshua Muravchik, William Kristol, Charles Krauthammer, Richard Perle and Paul Wolfowitz, receive considerable attention.

\footnotetext{
${ }^{37}$ Although my approach differs (as I explain in the following chapter), I tend to focus on many of the same neocons that Garry Dorrien does in Imperial Designs: Neoconservatism and the New Pax Americana (2004). In addition to many of the second-generation neocons identified in this book, I also heavily emphasise the foreign policy contributions made by first generation neocons such Norman Podhoretz, Jeane Kirkpatrick, and Daniel Patrick Moynihan. These thinkers, their backgrounds, and their foreign policy contributions, receive attention in Peter Ehrman's The Rise of Neoconservatism: Intellectuals and Foreign Affairs 1945-1994 (1995).
} 
Of course, this is not an ironclad rule. Anyone familiar with the backgrounds of these intellectuals will know that they often flit between the world of academia/thinktanks/policy institutes, and the world of public service. Paul Wolfowitz, while spending much of his time in government, earned $\mathrm{a} \mathrm{Ph}$ and has a record of studying and teaching at America's most prestigious universities. ${ }^{38}$ Although some neoconservatives are excluded in this thesis, every effort has been made to understand the intramural disputes among neoconservatives. Too often, I believe, failure to confront forthrightly the writings and contributions of some of the most prominent neoconservative intellectuals has led to slipshod analysis.

Take, for instance, the previously cited article of Stephen Hurst, an article which attempted to distinguish the foreign policy positions of neoconservatives and conservative nationalists in order to show that the neoconservative influence on the Bush administration was vastly overstated. According to Hurst, it was conservative nationalism, a category in which he places Donald Rumsfeld and Dick Cheney, which had the greatest impact on the Bush administration's approach to American foreign policy, not neoconservatism. "Despite a consensual core of key beliefs," Hurst argues when identifying points of convergence and divergence between the two categories,

conservative nationalists and neo-conservatives are clearly two distinct groups with important intellectual disagreements on fundamental issues. They agree on the need for a strategy of global predominance, the unilateral exercise of US power for the global good and the nature of the primary threat to that strategy and how to deal with it. Whereas conservative nationalists would draw the line at that point, however, neo-conservatives want to go further, and pursue a more ambitious strategy of democracy promotion and nation-building (emphasis added) (Hurst, 2005: 84).

For Hurst, the key difference centres upon "democracy promotion" and "nation building." Yet Hurst is only able to make this argument because he completely overlooks the substantive contributions of Jeane Kirkpatrick and Paul Wolfowitz. Unless Hurst considers these thinkers "conservative nationalists," a description very much at odds with the existing literature, his argument becomes quite problematic.

\footnotetext{
${ }^{38}$ For a useful summary of Wolfowitz's early career, see Mann, 2004: Ch. 2.
} 
As I demonstrate, neither Kirkpatrick nor Wolfowitz were too enthused about America's nation-building efforts. Yet, for reasons which will become clear as the thesis progresses, both still qualify as neoconservatives. If one is to define neoconservatism in an ideational way, then Paul Wolfowitz and Jeane Kirkpatrick are very much simpatico with Robert Kagan and Charles Krauthammer. The dispute over nation-building is a practical policy dispute, one which cannot be overlooked or neglected. But it should not conceal the ideological mindset all neoconservatives share, and the degree to which this mindset can lead to calls for ideological crusades against ideological foes. When Hurst attempted to associate a number of ideas and beliefs with neoconservatism, he did not even mention the importance neoconservatives assign to ideology.

Authors cannot overlook contributions of neoconservative thinkers as important as Wolfowitz and Kirkpatrick simply because they do not neatly fit into innovative categories aiming to elucidate rival conservative approaches to American foreign policy. Yet it must also be accepted that studies on neoconservatism cannot cover the field, for the selection of who to focus on is more than a little arbitrary. Neoconservatives themselves do not make the task any easier, for they display different levels of enthusiasm for the label. Robert Kagan, for one, has always maintained that he is a foreign policy liberal (see Packer, 2005: 19). Whether Kagan, though, can be excluded from a study on neoconservatism is somewhat contestable. Kagan, I believe, is of great significance. In fact, if one is defining neoconservatism in an ideational way, Kagan is the most "neo" of the neoconservatives. He plays a prominent role in all of the chapters comprising the body of this thesis, and is one of the most thoughtful neoconservative intellectuals. Even his critics begrudgingly confer a modicum of respect. Jacob Heilbrunn calls him "the most gifted neoconservative" (Heilbrunn, 2008: 244).

So although there is always going to be a degree of arbitrariness when determining who should qualify as a neoconservative, this thesis focuses on the writings and pronouncements of neoconservatives who have been identified as such in the contemporaneous literature on neoconservatism. It does not examine the writings of all those who have had the appellation attached to them, but it does cast its net wide enough to examine neoconservatism in all its complexity and richness. Divisions within this intellectual community will be explored in the following chapters just as areas of continuity will be identified. If there is one important finding in this thesis it 
is that there is more ideational continuity among neoconservatives than is sometimes allowed for. In the next chapter, I review the literature which has analysed the neoconservative approach to American foreign policy. Too often, I argue, scholars, Francis Fukuyama being the most noteworthy, have overlooked the continuity between Cold War and post-Cold War neoconservatives. It is for this reason that I have attempted to emphasise the contributions of the most prominent neoconservatives throughout each of these historical periods, drawing attention to the many points of ideational convergence.

That said, it must be noted that this thesis occasionally emphasises the importance of the ideas of popular legislators such as Henry Jackson, regional experts such as Bernard Lewis, and strategic analysts such as Albert Wohlstetter. Few of these men are identified in the existing literature as neoconservatives themselves, but each had a profound impact on neoconservative thinking. In the relevant chapters, I explain why these figures are important and how their ideas were appropriated by neoconservative intellectuals. After all, if one is going to define neoconservatism through the ideas and beliefs of its intellectuals, then one must have some understanding of the roots of these ideas.

Of course, it can be fairly asked whether neoconservatism is an ideology capable of prescribing a course of action to be followed by policy-makers in the future. The question is not easily answered, for the term "ideology" itself is contested. The way in which Michael Freeden discusses ideology in Ideologies and Political Theory: A Conceptual Approach (1996) is very different to the way in which ideology is discussed in Michael Hunt's Ideology and U.S. Foreign Policy (1987). If an ideology is taken to refer to "mass belief systems," then there is nothing inherently wrong with seeing neoconservatism as an ideology with a common set of assumptions relating to what America's role in the world should be, and why nations behave the way they do. If, however, it calls for a degree of introspection requiring neoconservatives to answer questions relating to the nature of man and the proper relations between them, then neoconservatism may fall short. As Williams notes when describing the way in which neoconservatives engage with the dominant issues of the day: "these engagements tend to be phrased in a highly politicized and often polemical language that sits uncomfortably with the culture of scholarly discourse and with overtly theoretical debate in particular" (Williams, 2005: 308). 
What is more important than determining whether neoconservatism conforms perfectly to what political scientists and political theorists describe as an "ideology" is what the label is interpreted to mean. How do we think of it? And how should it be presented when future generations wish to understand the set of ideas which arguably shaped, or at least gave some intellectual coherence to, the Bush administration's approach to American foreign policy? This chapter has spent considerable time emphasising the core neoconservative ideas and beliefs which should give meaning to the neoconservative label. These are the beliefs and ideas which will be explored with greater thoroughness in the following chapters.

In short, the belief that the United States is entrusted with a unique responsibility to defend the very idea of human rights and advance liberal democracy around the world has been coupled with an overwhelming faith in America's preponderant power. This constitutes the core of neoconservatism's foreign policy ideology, socalled. Of course, this brief description hardly does justice to neoconservative ideas, their evolution, and the subtle points of divergence and convergence which has existed among neoconservative writers over the past several decades. The chapters that follow will expand on the points made in this introduction, defining neoconservatism not in the way that neoconservatives define themselves (with the exception of Irving Kristol, most neoconservatives are not that self-reflective), but through the ideas and beliefs which have been articulated in a body of work which continues to grow even in the Obama era.

\section{A Final Word: Neoconservatives - You Are Either With Them Or Against Them!}

To put it mildly, few intellectual communities or ideological movements have aroused such impassioned debate as have the neoconservatives discussed in this thesis. Consistent with the tenor of the dialogue, this thesis is not merely descriptive. Although every attempt is made to understand the ideas and beliefs of the actors as they themselves understand them, there are a number of critical observations made. For neoconservatism's harshest critics, they will not be critical enough. For neoconservatives themselves, there will be more than enough to contest and dispute. The criticisms are made, though, in the realm of ideas. Neoconservatism must stand or fall on the credibility of the ideas and beliefs of its leading foreign policy intellectuals. Defining neoconservatism through these ideas and beliefs has become 
the most productive way of defining this intellectual community. But it is also, I believe, the most productive way of critiquing the neoconservative approach to American foreign policy.

Initially enchanted with aspects of this approach, many thoughtful IR theorists such as Francis Fukuyama have slowly come to distance themselves from an intellectual community whose ideas no longer appear as attractive after America's experience in Iraq. Neoconservatism, however, is not without its defenders. When Douglas Murray wrote his defence of neoconservatism, he expressed his hope that America's receptiveness to neoconservative ideas would remain undimmed even after Iraq. "I take it as a truth throughout this short book," he explained, "that the receptiveness of the American public to neoconservatism can only grow the freer the public are to understand it as it actually is" (Murray, 2006: xix). This thesis comes to a very different conclusion. Neoconservatives are by no means insincere in expressing their deepest foreign policy convictions, nor are they unthoughtful. Indeed, their ideas and arguments had considerable persuasiveness, a persuasiveness which became even more pronounced after the terrorist attacks on September 11, 2001. After these attacks, it was easy to believe in the need for a vigorous display of American power; it was easy to believe in the purity of America's values; and it was easy to believe in the desirability of waging an ideological war against a new totalitarian enemy. It was easy, I argue, but not wise.

\section{Conclusion}

This chapter has outlined the argument made in this thesis, and explained why a more ideational and thematic approach to studying neoconservatism will yield valuable insights into an intellectual community forever linked to one of America's most polarising wars, the war in Iraq. Guided by the assumption that the traditional emphasis on the ideological migration of neoconservatives is no longer as relevant as it once was, this thesis argues that neoconservatism should be defined more by the beliefs and ideas of its leading foreign policy intellectuals. This chapter highlighted the content which will be covered throughout the body of this thesis, explaining the significance and relevance of each aspect of the neoconservative approach to American foreign policy. It concluded by analysing the importance of ideas in politics and explained why neoconservatism must remain a serious candidate for 
academic inquiry. By defining neoconservatism through the ideas and beliefs of its leading foreign policy intellectuals, I concluded, one is able to both discern and persuasively critique the neoconservative approach to American foreign policy. Before these ideas and beliefs are explored, though, it is important to examine the dominant literature on neoconservatism. That is the purpose of the following chapter. 


\section{Chapter Two \\ $\underline{\text { Neoconservatism and its Authors }}$}

This chapter identifies three distinct approaches that scholars and commentators have adopted when writing about neoconservatism. First, I critically assess some of the arguments made by those who link neoconservatism to the ideas of Leo Strauss, a political philosopher renowned for enriching the study of classical political philosophy. If these scholars and commentators have anything in common, it is their attempt to de-Americanise neoconservatism. Regardless of whether it is the writings of a German political theorist or the presence of an all influential "Jewish Lobby,"39 there has been a significant attempt to place neoconservatism outside the "mainstream" foreign policy debates in America. This approach, I argue, is the weakest and least enlightening of all the approaches adopted by those writing about neoconservatism.

Second, those who have written specifically about neoconservatism tend to write historical narratives interspersed with biographical portraits of the intellectual community's figureheads. ${ }^{40}$ This narrative tells an essential part of the neoconservative story, but it is an approach often adopted by social commentators, political pundits, and social theorists. This thesis adopts a very different approach, for not only is there little room left to manoeuvre if one was to traverse a similar path, but such an approach is not conducive to a close textual analysis of neoconservative foreign policy ideas. Most of these authors, I argue, do not have a solid background in IR theory, and even the most cursory of glances at their bibliographies tends to suggest that they are not as conversant with some of the wider debates dominating the discipline as one may anticipate.

Third, a select few IR scholars have engaged with certain aspects of the neoconservative approach to American foreign policy, focussing most heavily on the neoconservative quest to perpetuate American military preponderance. These scholars often draw attention to the 1992 Defense Planning Guidance, a strategic document prepared for release at the end of the first Bush administration. While this

\footnotetext{
${ }^{39}$ This debate, as I explain below, was sparked by John Mearsheimer and Stephen Walt in 2006 in the London Review of Books. See Mearsheimer and Walt, 2006; and 2007.

${ }^{40}$ In this chapter, I tend to focus on the books written specifically about neoconservatism. There are, to be sure, several good studies on American conservatism and ideological movements that provide their own truncated but similar historical accounts. See Dionne, 2004; Micklethwait and Wooldridge, 2005; Nash, 2006; and Wolfson, 2004.
} 
body of scholarship has identified one key aspect of neoconservatism, it has insufficiently analysed, I argue below, the origins of neoconservative calls for the perpetuation of American military preponderance. Only by returning to the NixonKissinger era can one begin to appreciate how the ideas embedded in neoconservative critiques of détente laid the groundwork for the arguments made by neoconservative unipolarists in the 1990s.

The chapter concludes by emphasising the importance of the sources relied upon throughout the course of this thesis. Although much of the analysis in the following chapters is based upon an interpretation of many primary sources, there has been a wider literature consulted. This literature, I explain, enables neoconservative ideas to be contextualised and critiqued. It is a literature encompassing IR theory and a considerable amount of diplomatic history. Explaining the relevance and utility of this literature, therefore, is a task of particular importance.

The central purpose of this chapter, though, is to identify the dominant approaches adopted by the secondary literature on neoconservatism. While this literature has undoubtedly informed the approach I have adopted, the thesis takes its cues more from neoconservative writings than from secondary interpretations. In addition to delineating these approaches, the chapter emphasises both the limitations and contributions of each. It explains, furthermore, how this thesis both supplements and improves the existing secondary literature which has analysed the neoconservative approach to American foreign policy.

\section{$\underline{\text { Leo Strauss \& Neoconservatism }}$}

One approach adopted by those writing about neoconservatism is an approach shaped by political theory. It is an attempt to de-Americanise neoconservatism by emphasising the influence Leo Strauss purportedly had on several neoconservatives who served in the lower rungs of the Bush administration. ${ }^{41}$ Strauss was a philosopher of great influence and significance, one who revived the idea of natural right, examined the conflict between Jerusalem and Athens, and emphasised the negative consequences of the fact-value distinction prevailing in modern day social

\footnotetext{
${ }^{41}$ For an introduction to the work of those who make this argument, see Hirsch, 2003; Mason 2004; and Singer, 2004.
} 
science. ${ }^{42}$ Born in Germany in 1899, Strauss left in 1932, settled in America in 1937, and "spent his most productive years" teaching at the University of Chicago between the years of 1949 and 1967 (Anastaplo, 1999: 3). He introduced his students to the work of the great thinkers of the past, encouraging them to read philosophic texts with the utmost patience and care. The goal was to encourage them to develop an appreciation of the permanent questions, questions which have consumed and bedevilled the greatest minds since time immemorial. "Strauss and those he influences," explains one of Strauss's most famous students, "are stirring up the students, getting them to read old classics with a passionate seriousness, provoking them to ask all sorts of unusual questions - about the books, about the soul, about God, about morality, about democracy" (Pangle, 1989: x).

There are, to be sure, several neoconservatives who acknowledge Strauss's influence on them. Irving Kristol, who credits Strauss as one of his greatest intellectual influences, acknowledges, "Encountering Strauss's work produced the kind of intellectual shock that is a once-in-a life-time experience. He turned one's intellectual universe upside down" (Kristol, 1995: 7). Strauss achieved such a feat because he encouraged his students to return to the classics. He "trained his students," Kristol explained, "to look at modernity through the eyes of the 'ancients' and the premoderns, accepting the premise that they were wiser and more insightful than we are" (Kristol, 1995: 8). Strauss's writings do lend themselves to Kristol's cultural conservatism, ${ }^{43}$ and there is an overlap between Straussians and neoconservatives in their "common revulsion against 'the sixties' and the utopian political immoderation and insobriety for which that decade stands" (Zuckert \& Zuckert, 2006: 266). Yet, as I explain below, there is reason to question the link between Straussianism as a philosophical way of life which is wary of liberal modernity, and neoconservatism as a form of intellectual activism committed to the defence of the national idea of America.

Many scholars have nonetheless maintained that the link between Strauss and neoconservatism is a strong one. Shadia Drury, a political theorist who is one of Strauss's most devoted and persistent critics, argues, "there is a definite connection

\footnotetext{
${ }^{42}$ For an excellent overview of the dominant themes of Strauss's work, and those of the students he has inspired, see Deutsch, 1999.

43 "From cultural conservatives and the political philosopher Leo Strauss," Kristol explains, neoconservatism "has learned to appreciate the significance of precapitalist moral and philosophical traditions" (Kristol, 1983: xii).
} 
between the political ideas of Leo Strauss and the ruinous state of American democracy and its tragic foreign policy" (Drury, 2005: x). Other critics of Strauss such as Jacob Heilbrunn acknowledge that "Strauss has been wrongly used to tar the neoconservative movement as deceptive and dishonest." Yet even these qualifications do not prevent Heilbrunn from concluding that Strauss's “influence on the movement is clear" (Heilbrunn, 2008: 90). Both Drury and Heilbrunn present Strauss in the most negative of lights, arguing that Strauss's influence on neoconservatism is a noxious one. The gravamen of their argument, in short, is that Strauss was a closet nihilist who believed the vulgar majority must be manipulated by the wise few who appreciate the precariousness of civil society and promote "noble lies" in order to retain power, maintain social order, and establish virtue in the citizenry. $^{44}$

Drury draws attention to the fact that Paul Wolfowitz, President Bush's first term Deputy Secretary of Defense, was once a student of Allan Bloom's, undoubtedly Strauss's most famous student and the author of the widely read The Closing of the American Mind (1988). This was a book in which, as Drury puts it, "Bloom denounced American liberal society for being empty, nihilistic, and meaningless" (Drury, 1988/2005: x). Drury's interpretation of Bloom's work is not without foundation, for Bloom's The Closing of the American Mind is hardly a celebration of American culture. It is a book in which Bloom laments the state of the souls of his students, a degraded and corrupted state, he believed, born out of a higher education mired in relativism. "Who," Bloom would ask his students, "do you think is evil?" Upon hearing their responses, he regretfully concluded, "They have no idea of evil; they doubt its existence" (Bloom, 1988: 67).

Drury's attempt to link Strauss and Bloom to Wolfowitz, however, yields questionable conclusions. "In planning the war against Iraq," she asks, was "Wolfowitz providing the cure to the malaise diagnosed by his teacher? Was he providing the antidote to modern nihilism? I do not pretend to know," she acknowledged. "What I do know," Drury concluded, "is that enthusiasm for war is integral to Straussianism" (Drury, 2005: x). Drury, however, rarely cites Wolfowitz

\footnotetext{
${ }^{44}$ As Heilbrunn put it, "Strauss (intentionally or otherwise) propagated the idea of an elite that could guide the vulgar multitude; he apparently regarded religion as a delusion, but a healthy one that had to be outwardly respected, lest society dissolve into relativism and anarchy; and he seems to have doubted that liberalism, and liberals, had sufficient resolve and will to stand up to totalitarian forces" (Heilbrunn, 2008: 92).

${ }^{45}$ For an interesting discussion on Bloom's views on liberal education, see Nicgorski, 1999: Ch. 13.
} 
to support such claims. This, in fact, is one of the core problems with the arguments of those attempting to link Strauss with neoconservatism. One is always left wondering how exactly Strauss's ideas correspond with those of neoconservative foreign policy intellectuals. The link made is often a somewhat simplistic one, always centring upon the idea of a "noble lie" or the need to combat totalitarianism. ${ }^{46}$ Wolfowitz's ideas on international order and American power, I argue, are highly questionable, but he is not a war-crazed Straussian committed to infusing meaning into the lives of Americans by calling for perpetual war. Throughout the 1990s, in fact, he was much more cautious in calling for the employment of American power than he was after the terrorist attacks on September 11, 2001.

There is also good reason to conclude that Strauss would never have recognised let alone endorsed the ideas justifying America's intervention in the 2003 Iraq War. Strauss, for instance, once argued that "no bloody or unbloody change of society can eradicate the evil in man: as long as there will be men, there will be malice, envy and hatred" (Strauss, 1978: 5). This sits somewhat uneasily with the neoconservative belief, to quote Walter Russell Mead, "that the Arab world was teeming with Lockean democrats ready to build stable and liberal modern states" (Mead, 2007). The arguments linking Strauss to neoconservatism, in short, are contestable. If one reads Strauss to understand neoconservatism, one is unlikely to develop an appreciation for either. One of the virtues emphasised most frequently by classical political philosophers, Thomas Pangle explains in his dissection of Strauss's corpus, is the virtue of moderation, a virtue that can be just as applicable to a nation's foreign policy as it is important to a citizen's private life (Pangle, 2006: 87). The neoconservative war of ideology, I argue, precludes even the possibility of a moderate foreign policy.

\footnotetext{
${ }^{46}$ The journalist Seymour Hersh, for instance, links Strauss's work on esotericism to the case made for the war against Iraq, a war said to be based on questionable justifications. See Hersh, 2004: 219-221. Drury is even bolder, arguing, "Led by the neoconservatives, the administration of George W. Bush used lies to manipulate public opinion in order to justify a costly and needless war - the invasion of Iraq in 2003. It misled the American people into thinking that the tyrannical Saddam Hussein of Iraq had stockpiles of the most lethal weapons of mass destruction known to man and that he was connected to al-Qaeda" (Drury, 2005: xxii). And, of course, as Drury argues, Strauss is considered to be the "key to understanding the political vision that has inspired the most powerful men in America under George W. Bush" (Drury, 2005: xii). The allegation that the Bush administration and the neoconservatives who were a part of it deliberately lied, in my opinion, is questionable. It would be the height of political foolishness to spend so much time and risk so much political capital on a justification for a war that its architects knew was going to be undermined once the war concluded. One could argue that the war's architects were too eager to acquire and perhaps manipulate intelligence reinforcing a conclusion they believed to be true, but that is a different and more nuanced argument. In addition to consulting Strauss's Persecution and the Art of Writing (1988), for an exploration of Strauss's views on esotericism, see Pangle, 2006: 56-65; and Zuckert \& Zuckert, 2006: Ch. 4.
} 
Rather, it leads to a foreign policy characterised more by its "imprudent vehemence" than its circumspection.

According to Strauss, there are very real limits on what can be achieved in political life. It was Plato's Republic, according to Strauss, that most clearly demonstrated the limits of politics. In summarising the Straussian position on the search for the best regime in The Republic, Pangle asserts,

classical political philosophy conceives the 'best regime' not as an 'ideal to be realized, or even as something to be approached and worked toward; the elaboration of the best regime is intended, rather, as a subtly playful thought experiment meant to reveal the limitations on what can be expected from all actual political life (Pangle, 2006: 46).

For most Straussians, Pangle included, it was Machiavelli who invented the world of modern politics and immoderate ambitions. In Justice Among Nations: On the Moral Basis of Power and Peace (1999), Pangle and his co-author, Peter Ahrensdorf, emphasise Machiavelli's departure from the classics. They explain, "Machiavelli means to reject the contention of classical rationalism that civic virtue, to be as healthy and as reasonable as possible, must recognise a ceiling upon its hopes and its capacities" (Pangle \& Ahrensdorf, 1999: 128). Without delving into an extended discussion on these theoretical claims, it seems more than reasonable to conclude that Strauss, and the classics he worshipped, would have been more than a little uneasy with the extravagant political projects conceived in the minds of the neoconservatives who became such strong supporters of the 2003 Iraq War.

Although some of the attempts to link Strauss with neoconservatism remain problematic, there is a more sophisticated attempt to make this link which centres upon a much deeper theoretical claim. It is a claim carrying considerable pertinence to the argument I make in the following chapter. Drury is convinced that "whether they understand Strauss or not, all neoconservatives share his profound antipathy to secular liberal society" (Drury, 2005: xii). Assuming that liberal societies are vulnerable to nihilism, Strauss, according to Drury, believed "philosophers must pay

\footnotetext{
${ }^{47}$ This is a term used by liberal IR theorist Michael Doyle to describe one of the potential dangers that liberal states face when confronting illiberal states, but the term is just as applicable, if not more so, to neoconservatives and their war of ideology. See Doyle, 1996: 31.
} 
lip service to the myths and illusions they have fabricated for the many" (Drury, 1999: 18). In order to rescue the American regime from the degrading influence of relativism, the wise elite, according to Drury's Strauss,

must champion the immutability of truth, the universality of justice, and the selfless nature of goodness, while secretly teaching their acolytes that all truth is fabrication, that justice is doing good to friends and evil to enemies, and that the only good is one's own pleasure (Drury, 1999: 18).

Drury is not alone in this assessment. Michael Williams, one of the few prominent IR scholars to show any propensity to explore neoconservative ideas, attempted in 2005 to examine the theoretical foundations of the neoconservative conception of the national interest. This attempt is of immediate relevance, for Williams is the only scholar to directly take up the question I examine in the following chapter. Williams is an erudite IR theorist, one who avoids the more polemical claims made by Drury. Like Drury, though, he emphasises the concerns neoconservatives "share" with Strauss about a corrupt modernity in which citizens are bereft of heroic inspiration, left only with a feeling of permanent emptiness. In order to combat these feelings, neoconservatives are said to believe that a more virtuous conception of interests, going beyond concerns with mere self-gratification and selfinterestedness, is vital to sustaining the American regime. Neoconservatives are said to believe that "Strong, socially vibrant conceptions of both the public interest and the national interest are essential if a political community is to combat the corrosive acids of modernity" (Williams, 2005: 321).

Williams implies that the neoconservative attempt to remind the American citizenry of America's historic mission, a mission requiring America to defend and advance liberal democratic principles around the world, is more of a rhetorical ploy, one aiming to revitalise a decadent liberalism through the provision of salutary myths relating to America's "virtuous" and "heroic" founding. "What is particularly important about (Irving) Kristol's thinking," Williams argues, "is the way in which he seeks to mobilize political resources within the modern, and especially the American, political tradition in order to combat" the threats posed by societal decadence (Williams, 2005: 309). "What is required," according to this interpretation of the neoconservative project, "is a commitment to ideals, to the meaning of the nation in a 
heroic sense capable of mobilising individuals to virtuous action in the public sphere domestically, and in foreign policy internationally" (Williams, 2005: 317). Only then, it was argued, could citizens salvage some sense of meaning from the national vacuousness characterising modern America.

The scholars cited above rarely entertain the possibility that far from trying to combat the dangers of a nihilistic modernity, neoconservative foreign policy thinkers are very much a product of modernity and its liberal assumptions. In the following chapter, I argue that neoconservative foreign policy thinkers are a product of the modern liberal world. The theoretical roots of the neoconservative conception of the national interest are found not in the corpus of Leo Strauss, but in the core idea of the Enlightenment and in the work of thinkers such as Thomas Hobbes and John Locke. The idea that government is instituted to secure the rights of the governed was an idea finding concrete expression in the American experiment in popular government. It is the protection of this idea which consumes the intellectual energies of neoconservatives. When reading the work of these intellectuals, one is more likely to hear an echo of Tom Paine than of Leo Strauss.

Granted, it is possible that this is a rhetorical ploy, concealing a desire to save America from a baleful liberalism capable of leading to Nietzsche's "men without chests." But there is good reason to question this argument. Williams over-relies on Irving Kristol in what is an otherwise impressive scholarly article. He recognises that Kristol is "not the most prominent of neoconservative writers on foreign policy," but nonetheless proceeds to base a large portion of his analysis on Kristol's writings (Williams, 2005: 309). Such an approach will always furnish strong evidence reinforcing the argument that neoconservatives are attempting to extricate America from modernity's afflictions and perils. Irving Kristol has long spoken about the need to re-infuse religion into America's public and spiritual life. "It is crucial to the lives of all our citizens, as it is to all human beings at all times," he once argued, "that they encounter a world that possesses a transcendent meaning, a world in which the human experience makes sense." A life of spiritual impoverishment, according to Kristol, courts personal and national malaise. "Nothing is more dehumanizing, more certain to generate a crisis," he explained, "than to experience one's life as a meaningless event in a meaningless world" (Kristol, 1992/1999: 134).

Neoconservative intellectuals, I argue, consider the preservation of America's national idea a vital national interest. They consider the idea of human rights to be 
fragile. The idea, and the liberal philosophy from which it has emerged, is an idea and a philosophy neoconservatives seek to preserve not because of their fears of a corrosive nihilism, but because of their sense of what America should stand for in the world. If this gives Americans a sense of purpose, then this is all for the better, neoconservatives would reason. But the attempt is born more by the desire to fulfil America's historic mission of advancing human rights and democracy than it is the desire to fulfil the moral void in liberal regimes.

Strauss was, as even his students admit, ambivalent about liberal America. Drury's extravagant claims, including regular comparisons between Strauss and Hitler, are challenged by many. ${ }^{48}$ But Strauss, as Jacob Heilbrunn fairly put it, did have "a tortured relationship with liberalism. He wasn't opposed to it; he wanted to save it; but he didn't trust it" (Heilbrunn, 2008: 95). ${ }^{49}$ In fact, one does not have to delve too deep into the work of Leo Strauss to confront his apprehensions about modernity and modern liberalism. "The crisis of modernity," Strauss once argued, "reveals itself in the fact, or consists in the fact, that modern western man no longer knows what he wants - that he no longer believes that he can know what is good and bad, what is right and wrong" (Strauss, 1989: 81). Whatever Strauss's misgivings about liberalism and modernity, they are not shared by today's neoconservatives, at least not in the realm of foreign policy. In the realm of domestic policy, there is a case to be made that there is an overlap, as most Straussians and neoconservatives remain cultural conservatives. Yet in the realm of foreign policy, neoconservatives do not have a tortured relationship with liberal America. They believe quite sincerely in its values, its principles, and its national mission.

Neoconservatism's key foreign policy intellectuals, furthermore, have had little to do with Strauss. With the exception of Irving and William Kristol, neoconservatives such as Paul Wolfowitz, Robert Kagan, Joshua Muravchik, Jeane Kirkpatrick, Daniel Patrick Moynihan, Henry Jackson, Richard Perle and Norman Podhoretz, have

\footnotetext{
${ }^{48}$ For a defence of Strauss and his students or at least a more detached appraisal of their ideas and influence, see Blitz, 2003; Deutsch \& Murley, 1999; Lenzer \& Kristol, 2003; Lilla, 2004a; Lilla, 2004b; Pangle, 2006; Tanguay, 2007; West, 2005; and Zuckert \& Zuckert, 2006. Included in this list are some of the most prominent interpretations and analyses of Strauss's work. Anyone wishing to develop an appreciation of the Straussian project and the questions that consumed the intellectual energies of Strauss and his students should consult this ever-growing body of work.

${ }^{49}$ For a good introduction to Strauss's views on the three waves of modernity, see Strauss, 1989: 8198; and Zuckert \& Zuckert, 2006: Ch. 2. Also, for a philosophic engagement between one of Strauss's most famous students and John Locke, see Pangle, 1990. This latter volume is a sceptical appraisal of Lockean political philosophy.
} 
tenuous to non-existent links with Straussianism. Robert Kagan has even written a self-deprecatory article for The Weekly Standard, claiming he had "never understood a word" Leo Strauss wrote. "I mean," Kagan explained, "not a single word. Nor have I been very good at understanding his disciples, really, and Pangle (one of Strauss's most famous students), from whom I once took two courses, can back me up on this" (Kagan, 2006a).

When Catherine and Michael Zuckert published The Truth About Leo Strauss (2006), they emphasised the fact that the first book written on neoconservatism by Peter Steinfels, The Neoconservatives: The Men Who Are Changing America's Politics (1979), had no references to Strauss or his alleged influence on neoconservatives (see Zuckert and Zuckert, 2006: 265). Nor was this the only, or even the most significant, pre-September 11 study failing to analyse the links between Strauss and neoconservatism. "Even those neoconservatives who do have some connection to Strauss are far from clearly followers of Strauss in their politics," Catherine and Michael Zuckert claim, adding:

To take the two best known: both William Kristol and Paul Wolfowitz deny that their political views and their political advocacy owe anything in particular to Strauss. Wolfowitz identified Albert Wohlstetter (an economist and strategic thinker who barely knew Strauss and certainly was no follower or adherent of his views) as the more significant influence on his thinking about foreign policy. Perhaps Wolfowitz looks to Strauss for his views on Plato and al Farabi, but apparently not on what to do about Iraq (Zuckert and Zuckert, 2006: 265).

Therefore, if many of the studies on neoconservatism conducted before the terrorist attacks on September 11, 2001, do not emphasise the influence of Strauss, to say nothing of neoconservatives themselves and the degree to which they contest the charge, then one is surely entitled to question the strength of the arguments of scholars who are now intent on demonstrating a connection between his ideas and the ideas of neoconservatives.

\footnotetext{
${ }^{50}$ Peter Ehrman's The Rise of Neoconservatism: Intellectuals and Foreign Affairs 1945-1994 (1995), the most comprehensive pre 9-11 study on the neoconservative approach to American foreign policy, also refrained from drawing attention to any relationship between Straussianism and neoconservatism.
} 
It should also be noted that Strauss's views on the Islamic world were incredibly respectful. Indeed, his views on esotericism were shaped, as Pangle points out, "in part by his early intense study of the great Platonic political theorists living in the world of medieval Islam and Judaism - especially al-Farabi and Maimonides" (Pangle, 2006: 58). It was the discovery of these medieval writings which "opened the young Strauss's eyes to the supreme question animating and preoccupying Socratic philosophy: 'the theologico-political problem"' (Pangle, 2006: 59). Strauss's respect for the Islamic world and the seriousness with which he took its philosophic contributions did not always find an echo in the writings of neoconservative intellectuals who often spoke after September 11 about the importance of wielding American power in a region of the world where, as Charles Krauthammer put it, "power, above all, commands respect" (Krauthammer, 2001a). There are very real limitations, in other words, to those arguments which have attempted to identify a convergence between the ideas of Strauss and the ideas of neoconservatives. Part of the attempt to make this link is perhaps driven by a need to de-Americanise neoconservatism, making it easier to persuade thoughtful readers that American foreign policy can and should be returned to its own best traditions. Whatever the motive, though, it has led to some contestable claims requiring serious scholarly analysis.

\section{Neocons and the Jewish Lobby}

Ever since Stephen Walt and John Mearsheimer published an article on the Israel lobby's "disproportionate" influence on U.S. foreign policy in the London Review of Books in 2006, which they subsequently expanded into a book, there has been an intense debate over the degree to which American foreign policy is shaped by ethnic lobbies. $^{51}$ The article itself raised the most inflammatory and provocative of questions: where do the loyalties of neoconservatives truly lie?

Mearsheimer and Walt define the Israel lobby broadly, but there is no doubt, according to these two IR scholars, that neoconservatives constitute an important part of the lobby. In fact, the authors explain the Iraq conflict almost exclusively in terms of the ardent Zionism of neoconservatives. After citing a number of opinion polls

\footnotetext{
${ }^{51}$ For a good general discussion on lobbies and U.S. foreign policy, see Newhouse, 2009.
} 
which showed that American Jews were less enthused about the Iraq War than most gentile Americans, Mearsheimer and Walt acknowledged that the war could not be blamed on Jewish influence in the United States. "Rather," they argued, the war waged to topple Saddam "was due in large part to the Lobby's influence, especially that of the neoconservatives within it" (Mearsheimer and Walt, 2006).

Mearsheimer and Walt were not the only scholars to discuss the influence of Israel on neoconservative thinking. Stephen Sniegoski's The Transparent Cabal: The Neoconservative Agenda, War in the Middle East, and the National Interest of Israel (2008) is the most detailed and exhaustive attempt to link neoconservatives with the policies of Israel's Likud Party, the right wing party which has produced national leaders such as Benjamin Netanyahu. Lest anyone overlook Sniegoski's central thesis, he was quick to make his argument in the most forceful of terms: "the aim of the neoconservative/Likudnik foreign policy strategy was to weaken and fragment Israel's Middle East adversaries and concomitantly increase Israel's relative strength" (Sniegoski, 2008: 5). This was the logic behind the Iraq War, according to Sniegoski, and the many other wars that this alliance of Likudniks and neoconservatives went on to advocate, most notably the proposed war against Iran.

When interpreting these claims, intellectuals will invariably apply some of their own prejudices to what is one of the most agonising of conflicts, the conflict between the Israelis and Palestinians. Even those who make the above claims, and certainly some of those who dispute them, can take their loyalties to dangerous extremes. One does not have to be a "Likudnik" to find Sniegoski's unqualified reference to the "Palestinian resistance" morally offensive just as one should not have to respond to charges of anti-Semitism if they consider Israel's expansion in the Palestinian territories a violation of the rights of Palestinians (see Sniegoski, 2008: 5).

Without delving into the complexities of the Israeli-Palestinian conflict, though, it is important to recognise that neoconservatives are strong defenders of the Jewish state. In "A Clear Break," a 1996 paper prepared for the incoming Netanyahu government, several neoconservatives, including Richard Perle and Douglas Feith, advised the incoming government to abandon the peace process. "The paper makes clear," according to Anatol Lieven, "that it rules out the "peace for land' idea on which the whole 'two-state' solution is based, describing this as 'cultural, economic, political, military and diplomatic retreat"' (Lieven, 2004: 178). 
These arguments certainly cannot be dismissed, for the authors make a number of compelling claims which demonstrate the degree to which many neoconservatives identify with the Jewish state and segments of the Israeli right. Yet what they truly reveal about the neoconservative approach to American foreign policy is a little unclear. Even authors such as Sniegoski who aim to "expose" the connections between segments of the hard right in Israel and neoconservatives often acknowledge the limitations of their studies. He explains,

To state that neoconservatives viewed American foreign policy in the Middle East through the lens of Israeli interest - and that this was the basis of the neocon Middle East war agenda is not to say that their support for Israel has been the beall and end-all of their foreign policy ideas (Sniegoski, 2008: 7).

This admission raises immediate questions. If neoconservative support for Israel is not the "be-all and end-all of their foreign policy ideas," then to what extent are studies such as Sniegoski's truly capable of illuminating the neoconservative approach to American foreign policy? Is it not possible that perhaps some of these other ideas which go unexamined in The Transparent Cabal may even strongly conflict with those of the Israeli right? According to Walter Russell Mead, "The Israeli defense establishment was deeply sceptical of neoconservative hopes for a democratic renaissance in the Middle East following the removal of Saddam Hussein" (Mead, 2007). Is it not possible, in other words, that there is something distinctly American about neoconservatism?

The same question can be asked of Jacob Heilbrunn. His study, as we saw, argued that neoconservatism is best thought of as a Jewish mindset, one shaped by the Nazi holocaust and the Jewish immigrant experience in America, an experience characterised by intense class anxieties and ethnic discrimination. Heilbrunn makes a sophisticated argument, and it is certainly not without validity when it is applied to neoconservatives such as Norman Podhoretz. Podhoretz's frequent comparisons of modern leaders to Hitler suggest that his background may have fostered a peculiar cast of mind. Whether this argument is as persuasive when it is applied to Robert Kagan and Paul Wolfowitz, though, is more contestable.

First, it is not accurate to imply that the neoconservative approach to American foreign policy has not been shaped by American political culture. In Chapter 3, I 
examine the neoconservative attempt to protect the national idea of America, a project inspired by a deep faith in American values. Second, Heilbrunn spends considerable time analysing the Nixon-Kissinger era of détente, but does not firmly grasp the logic which shaped the strategic documents released in the immediate aftermath of the Cold War. Neoconservative doubts about the stability of a multipolar world were not shaped by a Jewish mindset; they were shaped by a very particular set of ideas extracted from IR scholarship and a rather prevalent interpretation of the origins of the twentieth century's two world wars.

It should be noted, furthermore, that neoconservatives are just as steadfast in their support for Taiwan as they are in their support for Israel. In the 1990s, they urged American policy-makers to renounce the policy of "strategic ambiguity," making it clear that America would "come to Taiwan's defense if China uses force or even threatens to use force" (Kagan \& Kristol, 1999). ${ }^{52}$ Both Israel and Taiwan, according to neoconservatives, are endangered liberal democracies living in hostile regions. Israel is surrounded by hostile Arab dictatorships supportive of terrorism, and Taiwan must uneasily co-exist with an emerging global authoritarian power in China. ${ }^{53}$ Neoconservatives who believe that America must defend these states appear to be driven more by feelings of ideological solidarity than ethnic identification. ${ }^{54}$ "Barring extraordinary events," Irving Kristol explained, "the United States will always feel obliged to defend, if possible, a democratic nation under attack from non-democratic forces, external or internal" (Kristol, 2003). For neoconservatives, this is as true for Taiwan as it is for Israel.

One should therefore resist the temptation to consider neoconservatives as nothing more than the most ardent of American Zionists. Resolute defenders of the Israeli state, they most certainly are. ${ }^{55}$ However, the greatest problem with the arguments of those who speak of these links, and emphasise the influence of a "Jewish mindset," is

\footnotetext{
${ }^{52}$ Kristol and Kagan were not the only neoconservatives discussing the importance of a reversal in America's policy of "strategic ambiguity" in relation to Taiwan. Paul Wolfowitz too has argued, "there is no way the United States could reliably assure China that we would stand aside from an attack on Taiwan under any circumstances, and it is a great mistake to encourage them to test whether we would" (Wolfowitz, 2000: 332).

${ }^{53}$ China, in fact, was considered the biggest security threat in the post-Cold War world. As Kristol and Kagan put it, "the biggest challenge to American interests in the world today comes from Beijing, not Moscow” (Kristol \& Kagan, 1999).

${ }^{54}$ When discussing the field of Republican presidential candidates in 2000, Kristol and Kagan concluded their article entitled "Free Taiwan" by arguing, "Senator John McCain rightly stood up for the people of Kosovo under attack by the brutal dictatorship in Belgrade. Does he have a similar concern for the well-being of the democratic people of Taiwan?" (Kristol \& Kagan, 1999).

${ }^{55}$ For a more historical look at the attachment of Gentile Americans to the Israeli state, see Mead 2008.
} 
that such arguments often lead authors to overlook many other core components of the neoconservative approach to American foreign policy. This creates the misleading impression that neoconservatism is a Jewish phenomenon which not only has little to do with American political culture, but also has little to do with some of the dominant ideas circulating within the discipline of International Relations. If this is the impression these studies create, it is an impression which is deeply regrettable. Although this thesis does not aspire to comprehensively discredit or confirm the arguments of those who have written extensively on neoconservative-Likud links, it does aspire to supplement them by providing a theoretically richer examination of the neoconservative approach to American foreign policy.

\section{$\underline{\text { Leaving Trotsky, finding Truman }}$}

A somewhat more measured approach to studying neoconservatism is adopted by those who have written an historical narrative. This narrative, I explained in the forgoing chapter, most commonly begins with the story of the New York intellectuals, a group of disparate intellectuals who, as children of Jewish immigrants, grew up through the Great Depression, confronting the ubiquity of economic hardship and Jewish discrimination. Most studies on the New York intellectuals emphasise the intellectual evolution of the likes of Daniel Bell, Nathan Glazer, Irving Howe, and Irving Kristol. ${ }^{56}$ The studies invariably begin by highlighting the Trotskyist roots of these thinkers, always emphasising in the process the intellectual ferment percolating City College in New York, the institution of higher learning where these thinkers came of age. What is common to this literature, we saw, is the emphasis it places on the ideological shift these intellectuals underwent. At the outset of Alexander Bloom's Prodigal Sons: The New York Intellectuals and their World (1986), arguably the most comprehensive study on the New York intellectuals, Bloom states, "The New York Intellectuals began as radicals, moved to liberalism, and sometimes ended up as conservatives" (Bloom, 1986: 6).

This set in motion one of the recurring themes featuring in all future definitions of the New York intellectuals and their neoconservative successors: the theme of

\footnotetext{
${ }^{56}$ As I outlined in the previous chapter, for an introduction to the literature on the New York Intellectuals, see Bloom 1986; Dorman 2000; Wald 1987; and Wisse 1987. These studies differ somewhat in their approach, but they provide more than an adequate introduction to this intellectual community.
} 
ideological migration. In Bloom's presentation, the radical leftism of the New York intellectuals morphs somewhat seamlessly into the sober Cold War liberalism defined by key anti-totalitarian tracts such as Arthur Schlesinger's The Vital Centre (1949) and Hannah Arendt's The Origins of Totalitarianism (1951). Other authors who spend more time analysing not so much the shift from radical leftism to Cold War liberalism, but the shift from Cold War liberalism to 1970s neoconservatism, tell a similar tale, presenting the shift as one of seamless transition. ${ }^{57}$

This thesis is not an exegesis on the thought of the New York intellectuals or a history of their intellectual development. Although the likes of Irving Kristol and Nathan Glazer have been described as neoconservatives, many of their generation's most significant intellectual contributions were in the realm of domestic policy, not foreign policy. As Nathan Glazer explains, foreign policy was not an integral "part of early neoconservatism" (Glazer, 2005: 17). The Public Interest, a journal founded in 1965 and initially edited by Irving Kristol and Daniel Bell, was the journal in which most of these contributions were made. George Nash, one of the most authoritative scholars on American conservatism, explained that the journal "soon developed themes and promulgated findings that did not sustain routine liberal assumptions," especially those underlying Lyndon Johnson's “War on Poverty” (Nash, 2006: 517). When commenting on the presuppositions these thinkers brought to their work and social policy analyses, James Q. Wilson explained,

If there is any article of faith common to every adherent, it is the Law of Unintended Consequences. Things never work out quite as you hope; in particular, government programs often do not achieve their objectives or do achieve them but with high or unexpected costs (Wilson, 1996: pp. vii-viii).

Since the New York intellectuals are more renowned for their contributions in the realm of domestic policy and their endless exhortations against the unintended

\footnotetext{
${ }^{57}$ In The Neoconservative Vision: From the Cold War to the Culture Wars (1996), Mark Gerson argues, "It is not always that a direct ancestor of an intellectual movement can be identified, but such is the case with neoconservatism. The ancestor is liberal anti-communism, a broad but distinct intellectual grouping that encompassed a number of prominent thinkers, most of them Jews from New York" (Gerson, 1996:31). Likewise, John Ehrman claims in Neoconservatism: Intellectuals and Foreign Affairs (1995), "the neoconservatives of the 1970s and 1980s were still representative of the cold war liberalism - often called the vital center - that developed after World War Two" (Ehrman, 1995: viii).
} 
consequences of ambitious social policies, I tend to focus on the neoconservative thinkers who came after them and engaged in the most pressing foreign policy debates of the 1970s and beyond. Even Irving Kristol, it should be noted, never became consumed by foreign policy concerns. "Anticommunism had long since ceased being an interesting intellectual issue for me," he explained when reflecting on his experience of becoming a neoconservative in the late 1960s and early 1970s (Kristol, 1993/1999: 486). Kristol's enemy was modern liberalism, and its corruption of America's moral and spiritual life. What "began to concern me more and more," he explained, "were the clear signs of rot and decadence germinating within American society - a rot and decadence that was no longer the consequence of liberalism but was the actual agenda of contemporary liberalism" (Kristol, 1993/1999: 486).

Neoconservatism, we have seen, has an odd relationship with liberalism. In the realm of foreign policy, neoconservatives do not question its presumptions. In the realm of domestic policy, the earlier generation were more than a little wary of how it could "corrupt" America's civic life. And it was within the realm of domestic policy that many of the New York intellectuals wished to play a role. When the Cold War finally ended, Irving Kristol, while regretting the absence of an ideological adversary, appeared to be relieved that America no longer had to concern itself with major considerations of foreign policy and national security. Adopting a line very much at odds with the neoconservative foreign policy intellectuals of today, he even called for the abolition of NATO as early as $1979 !^{58}$

The most pregnant battles of the future, Kristol anticipated after the Cold War ended, would be fought against a domestic liberal orthodoxy "that aims simultaneously at political and social collectivism on the one hand, and moral anarchy on the other" (Kristol, 1993/1999: 486). "Now that the 'other' Cold War is over," he warned,

the real Cold War has begun. We are far less prepared for this cold war, far more vulnerable to our enemy, than was the case with our victorious war against a global communist threat. We are, I sometimes feel, starting from ground zero, and it is a conflict I shall be passing on to my children and grandchildren. But it is a far more interesting cold war - intellectually interesting, spiritually interesting -

\footnotetext{
${ }^{58}$ For Kristol's calls for the abolition of NATO, see Kristol, 1979b/1983: Ch. 19.
} 
than the war we have so recently won, and I rather envy those young enough for the opportunities they will have to participate in it (Kristol, 1993/1999: 486).

Believing that neoconservatives could now cement their relationship with cultural conservatives and the evangelical right in order to combat the societal decadence creeping into American life, Kristol was clearly relieved to see the end of the Cold War and the Soviet Union.

This is, of course, not to suggest that the New York intellectuals and their generation were indifferent to American foreign policy. Their writings reflected the liberal anti-communism and opposition to Soviet totalitarianism typified by the Truman administration's approach to American foreign policy. The existing literature, for instance, ably draws attention to the success this generation had in establishing intellectual advocacy organisations such as the Congress for Cultural Freedom, which sought to dispel the benign image of Soviet communism prevalent in the West. ${ }^{59}$ Reflecting on his time as editor of Encounter, a magazine founded in London and published by the Congress for Cultural Freedom, Irving Kristol recalled,

its 'mission,' as it were - was to counteract, insofar as it was possible, the antiAmerican, pro-Soviet views of a large segment of the intellectual elites in the Western democracies and in the English speaking Commonwealth (Kristol, 1993/1999: 481).

While the contributions of the New York intellectuals in the realm of American foreign policy should not be discounted, a study of contemporary neoconservative ideas and their application to American foreign policy debates does not require extended references to them. As I explain below, neoconservatism and American foreign policy did not come together until the late 1960s. It was only in the aftermath of Vietnam that many Cold War liberals began to lose faith in the Democratic Party as they witnessed its leftward drift, evidence of which was said to be found in the party's embrace of candidates such as George McGovern, the 1972 presidential candidate who ran on the slogan, "Come home, America." 60 It was only at this time that one could begin to discern the neoconservative ideas which would reverberate throughout

\footnotetext{
${ }^{59}$ For the most comprehensive study on the Congress for Cultural Freedom, see Coleman, 1989.

${ }^{60}$ For a good account of this election, see Boller, 2004: Ch. 47
} 
the 1990s and beyond September 11, 2001. It is generally from within this time period that this thesis extracts the writings and speeches of the aforementioned figures and subjects them to close textual analysis.

\section{The Rise of Neoconservatism}

Like those who have written about the New York intellectuals, the most prominent authors who have published books on neoconservatism have generally written historical narratives interspersed with biographical portraits of those considered to be the most prominent and influential neoconservatives. ${ }^{61}$ This literature often draws attention to the post-Vietnam liberals who remained true believers in the TrumanAcheson approach to American foreign policy, emphasising the many criticisms these disillusioned Democrats levelled at President Carter and his quest for a brand of democratic exemplarism eschewing the use of military force. ${ }^{62}$ Following this, it often concludes by analysing the ascent of Ronald Reagan, an event heralded as a triumph for neoconservatism as many disgruntled Democrats such as Jeane Kirkpatrick transferred their party loyalties from the Democrats to Reagan's revived Republicans. ${ }^{63}$

Yet neoconservatism's relationship with Ronald Reagan, this thesis shows, is complicated. Neoconservatives undoubtedly became passionate Reaganites, shaping

\footnotetext{
${ }^{61}$ For an introduction into the literature which explores the ideological transformation of 1960s Cold War liberals into Cold War neoconservatives, see Dorrien, 1993; Gerson, 1996; Ehrman, 1995; and Friedman, 2005. For a study which adopts such an approach as described above, focussing more on domestic policy, though, see Steinfels, 1979. For three of the most recent studies on neoconservatism, see Clarke \& Halper, 2004; Dorrien, 2004; and Murray, 2006. This is the dominant literature on neoconservatism, and it is a literature which I will call on as the thesis progresses.

${ }^{62}$ H.W. Brands's study on American foreign policy has a helpful chapter that examines neoconservative opposition to President Carter's decision to rely on America's moral example as the best way to promote its ideals. See Brands, 1998: Ch. 10. Gary Dorrien's first volume has a chapter that examines the career of Norman Podhoretz, a chapter that chronicles in some detail his eventual disillusionment with the New Left and counterculture. See Dorrien, 1993: Ch. 4; John Erhman's study has a very good chapter on Daniel Patrick Moynihan, which summarises his battle on behalf of liberal democratic principles at the United Nations. See Ehrman, 1995: Ch. 3. Sara Diamond's work on rightwing movements in the United States has a chapter that provides a very useful summary of the history of neoconservatism, providing some interesting insights into the emergence of the Coalition for a Democratic Majority. See Diamond, 1995: Ch. 9; and Mark Gerson's study spends a considerable amount of time analysing the emergence of the counterculture and the neoconservative response to it. See Gerson, 1996: Ch. 3.

${ }^{63}$ See Ehrman, 1995: Ch. 5; and Friedman, 2005: Ch 8-9. Both of these books conclude by reviewing some of the Reagan administration's exploits in Central America. For an excellent study on the history of American anti-communism, which devotes several important chapters to the Reagan administration, including the role neoconservatives played in elevating Reagan to the presidency, most notably through their work on the Committee on the Present Danger, see Powers 1998: Ch.13.
} 
and guiding his policies in the Third World. However, Reagan, I argue, was not an ideologue, certainly not to the extent his neoconservative supporters were. The neoconservative war of ideology downplays the importance of statesmanship in the affairs of nations, leading neoconservatives to regularly dismiss the importance of summitry and personalities in international politics. This is a failure, I argue, produced by a set of beliefs relating to how nations can be expected to behave in the world. Ronald Reagan believed he could end the Cold War; his neoconservative supporters, to put it delicately, had some reservations.

In fact, this points to one of the more significant shortcomings in the literature tracing the history of neoconservatism. Those who have written an historical narrative do not engage with the wider IR and historical literature analysing the end of the Cold War. This is not so much a failure, it should be noted, as it is a limitation and shortcoming of the approach. When writing an intellectual history, one rarely has to go beyond the work produced by the intellectual community one is studying. Yet if neoconservatism is to be defined in an ideational way, then it deserves to be critically examined in a way that is guided by an appreciation of the wider debates in the discipline of International Relations. Although I explain the importance of the sources this thesis relies on below, a more thematic approach does allow one to examine neoconservatism in a more analytical way. It is an approach enabling one to avoid polemics while spotlighting neoconservatism's serious theoretical and ideational flaws.

Take, for instance, debates centring upon the Nixon-Kissinger era of détente, an era which remarkably receives little attention in the literature on neoconservatism. ${ }^{64}$ For an understanding of the competing philosophies and historical interpretations that guided policy prescriptions throughout this period, one requires a degree of familiarity not only with the speeches, the memoirs, and interpretations of the participants, but also with the historical and theoretical literature addressing questions of order, stability and great power war. The battles waged throughout this period were not just bureaucratic battles fought over arms-control minutiae, accessible only to the initiated; they were battles over ideas, the consequences of which are as significant today as they were at the time they were waged. In fact, one could argue that the Bush administration's grand strategy, a strategy which aimed to prevent the

\footnotetext{
${ }^{64}$ A notable exception is Jacob Heilbrunn's volume, which does provide a good history of the dispute Kissinger had with Henry Jackson and his followers. See Heilbrunn, 2008: 125-132.
} 
emergence of another independent pole of power in the world, was the crystallisation of neoconservative ideas circulating throughout the Nixon-Kissinger era of détente. These were ideas, I explain, relating to what preserves order and what causes great power war. There is, of course, a vast literature addressing these questions. In the following pages, I rely on this literature to both contextualise and question some of the key strategic assumptions and ideas promoted by neoconservative foreign policy intellectuals. Those who write historical narratives rarely engage with this wider literature, making their critiques less than compelling.

Another significant limitation, produced more by the passage of time than any inherent fault, is the emphasis these studies place on the ideological conversion of the first generation of neoconservatives. Defining neoconservatism through the ideological conversion of the first generation, as much of this literature does, is no longer as appropriate as it once was. Even Irving Kristol's brief flirtation with Trotskyism is often unduly emphasised. ${ }^{65}$ Of course, the ideological conversion of first generation neoconservatives will remain an important part of this intellectual community's history, as well it should. In many ways, this thesis supplements this part of the narrative by not only extending it into the twenty-first century, but by recasting the way in which neoconservatism can and should be thought about. If many of today's neoconservative intellectuals have not experienced this ideological conversion, then there is little sense in continuing to emphasise its importance.

Writing an article for The Weekly Standard in 2003, Irving Kristol expressed surprise at the degree to which neoconservatism had been associated with American foreign policy, claiming, "there is no set of neoconservative beliefs concerning foreign policy, only a set of attitudes derived from historical experience" (Kristol, 2003). In contrast, this thesis argues that there are indeed a set of core neoconservative beliefs, a set of beliefs which are both discernible and capable of defining neoconservatism.

\section{Neoconservatism, Ideas, and International Relations Theory}

Unlike the two approaches analysed above, the third approach adopted by scholars is one heavily shaped by IR scholarship. Although there has not been as much of a critical engagement as one may expect between neoconservatives and IR theorists, the

\footnotetext{
${ }^{65}$ Irving Kristol's Trotskyist phase did not last long. He had abandoned Trotskyism before he turned 22. See Kristol, 1995/1999: 11.
} 
assumption that the 2003 Iraq War was a product of neoconservative ideas galvanised several prominent IR theorists to attempt to counteract these ideas. One of the most prominent was Francis Fukuyama, a scholar previously sympathetic with neoconservative principles. Following the 2003 Iraq War, Fukuyama seemingly jumped ship. In America at the Crossroads: Democracy, Power, and the Neoconservative Legacy (2006), Fukuyama argued that following the Cold War neoconservative principles had begun to be interpreted in a way that "overemphasized the use of force and led logically to the Iraq War" (Fukuyama, 2006: xi). Fukuyama's celebrated break with his former neoconservative allies sparked a spirited exchange between himself and Charles Krauthammer. ${ }^{66}$

In America at the Crossroads, Fukuyama provides a foreign policy blueprint aiming to redirect American foreign policy away from the assertive unilateralism supported by neoconservatives and towards an approach that "takes international institutions seriously" (Fukuyama, 2006: 10) He begins the book, though, by making a number of questionable assertions relating to neoconservative foreign policy principles. Identifying four common principles, ${ }^{67}$ three of which he is largely sympathetic with, ${ }^{68}$ Fukuyama begins by claiming that "neoconservatism was based on a set of coherent principles that during the Cold War yielded by and large sensible policies both at home and abroad" (Fukuyama, 2006: xi). The subtext of this argument, indeed the subtext of this book, is that the first generation neoconservatives had promoted a responsible set of principles capable of guiding American foreign policy throughout the Cold War only to see those principles subverted and misconstrued by post-Cold War neoconservative militarists such as William Kristol, Robert Kagan, Charles Krauthammer, and Max Boot.

Such an argument, I explain, understates the continuity in ideas between Cold War and post-Cold War neoconservatives. It fails to ask to what degree the ideas promoted by first generation neoconservatives shaped the arguments of the second generation. This is a significant limitation of Fukuyama's study. Take, once again,

\footnotetext{
${ }^{66}$ For the opening exchanges in this lively debate, see Fukuyama, 2005; and Krauthammer, 2005.

${ }^{67}$ The four principles, according to Fukuyama, are: "a concern with democracy, human rights, and more generally the internal politics of states; a belief that U.S. power can be used for moral purposes; a scepticism about the ability of international law and institutions to solve serious security problems; and finally, a view that ambitious social engineering often leads to unexpected consequences and often undermines its own ends" (Fukuyama, 2006: 4-5).

${ }^{68}$ For an elaboration of the principles Fukuyama wishes to incorporate into his approach to American foreign policy, see Fukuyama, 2006: 9-11.
} 
the importance neoconservatives assign to ideology in international politics. Neoconservatives have long spoken about the importance of an ideologized foreign policy, both throughout the Cold War and the war on terror. Their advocacy of an ideologized foreign policy did not, I argue, yield responsible policy prescriptions throughout either conflict. Like Hurst, when Fukuyama enumerates four principles said to be guiding the neoconservative approach to American foreign policy, absent from his list was any mention of the role neoconservatives believe ideology should play in American foreign policy. In fact, Fukuyama sympathises with the neoconservative belief that a nation's conduct in the world is shaped by the character of its regime, but this belief was not embraced by neoconservatives because they had engaged in a detached examination of the democratic peace thesis; it was embraced, I argue, because their ideological combativeness required nothing less.

Fukuyama's criticisms of neoconservatives are not without foundation. His observation that neoconservative proponents of the 2003 Iraq War seemingly disregarded concerns with projects requiring a large amount of social engineering, concerns prevalent among first generation neoconservatives, is a thoughtful one (see Fukuyama, 2006: 6-7). Yet its relevance can be questioned. This was a principle that many New York intellectuals applied to domestic policy analyses; it has not been a principle neoconservatives have incorporated into their approach to American foreign policy. ${ }^{69}$ The predecessors of today's neoconservatives are not the Trotskyites who became Cold War liberals in the aftermath of World War Two; their predecessors are the Democrats who became Reaganite Republicans as a result of their contempt for the New Left, the counterculture, and McGovernism.

Fukuyama himself recognises the distinction, explaining, "The first formative battle that shaped neoconservatism was the fight with the Stalinists in the thirties and forties; the second was the one with the New Left and the Counterculture it spawned in the 1960s" (Fukuyama, 2006: 18). Yet Fukuyama's depiction of neoconservatism had little analysis of this second battle and the ideas of its participants, a battle much more relevant when it comes to the neoconservative approach to American foreign policy. His book, in fact, has two references to Norman Podhoretz, two references to Jeane Kirkpatrick, and one reference to Henry Jackson. There is also not a single

\footnotetext{
${ }^{69}$ Fukuyama himself reveals some ambivalence on this point. As he put it, "The critique of domestic policy begun by The Public Interest would ultimately have implications for U.S. foreign policy, but the connection was not a direct one and was never made by many neoconservatives. The more proximate origins of neoconservative foreign policy lie elsewhere" (Fukuyama, 2006: 21).
} 
quotation attributed to any one of these sources. It is, therefore, no surprise that Fukuyama overlooks the continuity in neoconservative ideas. The main goal of America at the Crossroads was not to substantively engage with neoconservative ideas; it was to craft an approach to American foreign policy Fukuyama labels "Realistic Wilsonianism" (Fukuyama, 2006: 9). This is an approach repudiating the assertive unilateralism of neoconservatives and re-emphasising the importance of economic development and international institutions.

Fukuyama was not the only IR theorist to craft his own blueprint aiming to redirect American foreign policy away from the "wayward" Bush years. John Ikenberry, one of America's leading liberal internationalists, strongly questioned the neoconservative quest to unshackle America from the international institutions created in the aftermath of World War Two. Much of what the neoconservatives had argued in relation to America unbinding itself from cumbersome institutions which sought only to entangle America in global forums such as the United Nations posed a direct challenge to Ikenberry's corpus. ${ }^{70}$ Ikenberry has long drawn attention to the role international institutions can play in creating a more orderly world. His belief that the "fundamentalist ideas" of neoconservatives had taken "Washington by storm" aroused more than his ire; it summoned his best intellectual efforts to combat the "fundamentalist thinking" said to be characteristic of neoconservative foreign policy writings and Bush administration policies (Ikenberry, 2004: 7).

Yet much of the work of Fukuyama and Ikenberry only emphasises certain facets of the neoconservative approach to American foreign policy. And even those facets they do explore are rarely examined with the degree of rigour and substance needed to understand how neoconservative ideas have evolved. Both Fukuyama and Ikenberry wrote about neoconservatism to counteract the foreign policy ideas they believed led America astray throughout the Bush years. There are, of course, always going to be merits to thoughtful grand strategies and contrasting American approaches to the world. Both Fukuyama and Ikenberry have made valuable contributions. But this thesis, it should be noted, does not aim to provide a blueprint capable of guiding American foreign policy in the Obama era; its purpose is to extract dominant themes

\footnotetext{
${ }^{70}$ Ikenberry's After Victory: Institutions, Strategic Restraint, and the Rebuilding of Order after Major Wars (2001), is his most definitive study of the attempts, some more successful than others, made after the Napoleonic Wars, the First and Second World Wars, and the Cold War, to construct international institutions capable of preventing a return to conflict. For a sampling of a number of essays written by Ikenberry, essays in which he continues to examine the relationship between institutions and order, see Ikenberry, 2006.
} 
familiar to many IR theorists, trace the evolution of neoconservative ideas, explore their continuity, and critically examine them. I write about neoconservatism not to counteract the ideas of neoconservatives - although I am more than critical of them but to understand their approach to American foreign policy.

\section{$\underline{\text { Neoconservatism and American Hegemony }}$}

In addition to the two IR theorists discussed above, those who adopt an approach to studying neoconservatism shaped by IR scholarship often emphasise the neoconservative quest to perpetuate America's military preponderance. No facet of neoconservatism, in fact, has been underscored more than the neoconservative belief that America must preserve its global hegemony. If there is one idea most closely associated with neoconservatism, this is it. There is, of course, a wider literature analysing whether America should be considered an empire. Some segments of the American right, often identified as paleo-conservatives, recoil at the suggestion, believing America should assiduously avoid costly military ventures and entangling alliances. Pat Buchanan, arguably the most prominent paleo-conservative, continues to level a considerable amount of obloquy at neoconservatives such as Paul Wolfowitz, presenting him as one of the main architects of America's global empire strategy who served in the Bush administration. ${ }^{71}$

In contrast, British historian Niall Ferguson has no such qualms about the emergence of an American imperium. He argues that America must not run away from the "empire" label; it must embrace it and act as all liberal empires should, governing failed societies, underwriting the global economy, extending its benign influence around the world. Ferguson, while hopeful that America will play such a role, harbours strong doubts about America's willingness to assume such burdens. "The danger," Ferguson fears, is that when America goes abroad it will "opt for premature decolonization rather than sustained indirect rule" (Ferguson, 2005: xi) Yet few of these studies dissect the strategic logic underlying neoconservative calls for the perpetuation of American military preponderance.

The most comprehensive and thorough study conducted by a scholar on the neoconservative quest to perpetuate American military preponderance is provided by

\footnotetext{
${ }^{71}$ For an introduction to Buchanan's views on "Wolfowitz's memorandum," see Buchanan, 2002: Ch. 2.
} 
Gary Dorrien. His second volume on neoconservatism, Imperial Designs:

Neoconservatism and the New Pax Americana (2004), is an attempt to trace the roots of these calls. Dorrien's book is undoubtedly a useful synthesis of the foreign policy writings of several neoconservatives over the last several years, and provides useful details on their personal backgrounds. He is a strong liberal internationalist critic of the neoconservative approach to American foreign policy. One of the major limitations of Dorrien's study, though, is the insufficient amount of time it spends analysing the competing ideas circulating throughout the Nixon-Kissinger era of detente. Explaining the goal of Imperial Designs, Dorrien states,

This book describes how the ideology of American global pre-eminence originated during the presidency of George H. W. Bush, developed in the 1990s, gained power with the election of George W. Bush, and reshaped American foreign policy after September 11, 2001 (Dorrien, 2004: 1).

Yet the goal of achieving "American global pre-eminence" did not, as Dorrien suggests, originate "during the presidency of George H.W. Bush." The ideas embedded in neoconservative critiques of détente paved the way for the neoconservative unipolarists in the 1990s. Like Fukuyama, Dorrien understates and fails to adequately explore the continuity in neoconservative ideas throughout these two periods.

Dorrien also fails to grasp the strategic logic driving neoconservative calls for the perpetuation of American military preponderance, logic which manifested itself throughout the Cold War and beyond. When it comes to the Nixon-Kissinger administration and its neoconservative critics, one needs to juxtapose their differing interpretations of the causes of the twentieth century's global conflicts. As I suggested above, when Henry Jackson and the neoconservatives he inspired rose up in protest at Kissinger's "amoral" balance of power politics, the battles were waged not only over abstruse arms control agreements and Jewish emigration, but also in the realm of ideas. Should America accept a multipolar world? If not, why not? Is a multipolar distribution of power in the international system threatening to international stability, as neoconservatives maintain? What particular set of historical lessons did neoconservatives derive from the twentieth century's two world wars which fostered the belief that America must perpetuate the post-Cold War unipolar 
moment? Are such interpretations reasonable? These last two questions, in fact, are the key questions to be asked if one is to truly understand and critically engage the strategic logic underpinning neoconservatism's quest for a pax-Americana. Dorrien's volume does not provide the answers to these questions because they are questions he does not ask.

Although Dorrien's volume spends some time analysing other aspects of the neoconservative approach to American foreign policy, the neoconservative quest to perpetuate America's military preponderance is the dominant theme. When I interviewed Michael Lind, a foreign policy intellectual at the New America Foundation, an institute renowned for its sharp critiques of the thinking infusing America's foreign policy establishment, he suggested that this was the one idea which should forever be linked to neoconservatism (Lind, interview, 15 February 2007). Lind makes several thoughtful criticisms of the neoconservative hegemonic grand strategy, I argue in Chapter 5, but this suggestion is contestable. There has always been more to the writings of neoconservative foreign policy intellectuals than their support for an American led unipolar international order. This is certainly an important aspect of their approach to American foreign policy, one requiring a critical engagement, but it is not the only aspect and should not be treated as such. Protecting the national idea and waging the war of ideology are neoconservative projects requiring thoughtful analysis, an analysis which does not dismiss but strongly probes. By defining neoconservatism through the ideas and beliefs of its adherents, this thesis provides a substantive engagement with neoconservatism at a more theoretical level, spotlighting not so much the failings of neoconservatism in practice, but the failings of neoconservatism in its meticulously constructed world of ideas.

\section{$\underline{\text { A Note on Sources }}$}

In making the arguments contained within this thesis, I have relied on a number of scholarly and historical sources. First, while the thesis has certainly been shaped by the secondary literature on neoconservatism, this segment of the literature is not the primary source relied upon. This chapter has discussed at length the various approaches adopted by authors who have written about neoconservatism, spotlighting their valuable contributions and shortcomings. Taking the ideas and beliefs of neoconservatives seriously, however, required more analysis of primary material, the 
voluminous amounts of articles and books neoconservatives have published over the past several decades. In his biography on George W. Bush, Jacob Weisberg thoughtfully explained his approach to studying decision-makers; it is an approach which is just as applicable to those studying the words and ideas of intellectual communities. "The key that unlocks the mystery of political motivation is seldom hidden in a locked vault," he explained. "It's usually right in front of us, in the words of decision-makers, who even when they are trying to dissemble and conceal, end up revealing far more than they intend" (Weisberg, 2008: xxii). Magazines and journals such as The Weekly Standard and Commentary are the repository of neoconservative ideas, and a large amount of time was spent combing through their archives. Neoconservatives have never been reticent when it comes to expressing what they believe in, and they have always found ways to ensure their voices are heard. In order to understand the neoconservative approach to American foreign policy, one must listen closely and re-examine conventional interpretations. That is the only way one can acquire additional insights or confirm suspicions.

In early 2007, I travelled to Washington, D.C., to conduct several interviews not only with a number of neoconservatives themselves, but also with a number of prominent foreign policy intellectuals in the United States such as Michael Lind, Anatol Lieven, and Robert Lieber. These scholars/research fellows were not selected at random. Each had published an influential volume on American foreign policy throughout the Bush era. Although they addressed different questions, each volume helped contextualise neoconservative ideas. Lieven's America Right or Wrong: An Anatomy of American Nationalism (2004) is a brilliant analysis of American nationalism, locating the roots of neoconservatism's (and the Bush administration's) messianism deep within American culture; Lind's The American Way of Strategy: U.S. Foreign Policy and the American Way of Life (2006) includes a large amount of material which should stand as one of the best analyses of the neoconservative hegemonic grand strategy; and Robert Lieber's The American Era: Power and Strategy for the $21^{\text {st }}$ Century (2005) provides some scholarly reinforcement to neoconservative ideas. Each of these authors were immensely helpful in allowing me to ask questions about their perspectives, some critical and others supportive, on the neoconservative approach to American foreign policy. In the chapters that follow, I will refer often to their work. 
At the time of my travels, of course, the Iraq War was not going well. Whether it was for this reason, or the burdens of a life dedicated to the development of ideas, it was not always easy to acquire access to a large number of neoconservatives. Be that as it may, I was able to speak to several of the most prominent. Richard Perle, William Kristol, and Joshua Muravchik, were all kind enough to give me considerable portions of their time. Although this was not exactly a wide sample of neoconservatives to interview, it was most certainly a very important sample. As editor of The Weekly Standard and son of Irving, William Kristol is arguably the most vocal neoconservative in the United States today. When the Republican Party was reforming itself in the 1990s, some would even describe the junior Kristol as the pivotal figure "in the transformation of the modern Republican Party" (Gerson, 1996: 353). Just as important as Kristol, though, is Richard Perle. Perle has been the classic Washington insider, serving more as a policy-maker than an intellectual activist. Beginning his career as a congressional aide to Henry Jackson, Perle would go on to serve the Reagan administration and the administration of George W. Bush. Joshua Muravchik, in contrast, has spent more time in think-tanks and policy institutes, churning out numerous articles and books. No neoconservative has written more about American values and ideals than Muravchik.

All of the interviews I conducted with these thinkers assisted in the development of my own ideas on neoconservatism and helped clarify unanswered questions I felt obliged to ask. The interviews gave me additional insights into the belief system of neoconservatives and their approach to American foreign policy. As I already stated, the approach of this thesis was, at least to some extent, shaped by a discussion I had with Joshua Muravchik in his office at the American Enterprise Institute.

The sources I have relied upon to frame the argument of this thesis have been selected because they are the most likely to demystify neoconservatism. They have been selected because they give meaning to the label "neoconservative." And labels, as I explained above, matter as much as ideas. "Labels matter," Stephen Hurst rightly argues, "because they shape our understanding of that which they describe" (Hurst, 2005: 76). By relying on the sources it has, this thesis aspires to give concrete meaning to the "neoconservative" label.

In addition to the large amount of secondary literature and primary material utilised throughout this thesis, there was, it should be noted, a wider literature consulted. It is a literature encompassing a diverse field, including IR theory and 
diplomatic history. This literature will be called upon as the thesis progresses, depending upon the area being covered. When this literature is utilised, it is enlisted not as an aid to resolve the tensions between the dominant scholars of International Relations. Nor is it enlisted to vindicate a favoured theoretical paradigm. It is called upon to help contextualise and critique neoconservative beliefs and ideas.

When it comes to evaluating aspects of the Cold War, the work of scholars such as John Lewis Gaddis, Melvyn Leffler, and Wilson Miscamble has been invaluable. In fact, one can hardly make any confident pronouncements on the Cold War if one is unfamiliar with the work of these Cold War historians. That is why every attempt has been made to consult their influential texts. The same approach has been adopted when I engage with other controversial questions. When it comes to evaluating Ronald Reagan, for instance, a large portion of the biographical and analytical literature on his life and presidency will be enlisted as supporting material, buttressing the arguments I make. When it comes to Iraq, the thesis relies on the dominant literature which has examined a war whose history has yet to fully unfold. Whatever aspect of the neoconservative approach to American foreign policy this thesis happens to examine, there is an attempt made to contextualise and critique the aspect by engaging with a wider literature.

Of course, I claim no expertise in these vast literatures, only enough conversance to be able to scrutinise the neoconservative approach to American foreign policy with the rigour it deserves. The scholars and historians writing on whether America should embrace "the responsibility to protect" and defend victims of genocide and mass atrocity, who examine the history of the Cold War, who dissect the presidency of Ronald Reagan, who explore the history of the Nixon-Kissinger era of détente, and who review the history of the Iraq War, are participants in their own internal debates with scholars and historians in their respective fields of study. It is not the purpose of this thesis to take sides in these debates any more than it is to emphasise them. Suffice to note, however, that there has been a large and diverse literature consulted, a literature encompassing the most influential and widely referenced texts in a number of different fields. 


\section{Conclusion}

For an intellectual community so devoted to the power of ideas, so committed to the triumph of their worldview, and so sure of their beliefs, a more critical engagement with neoconservatism in the realm of ideas is long overdue. Each of the approaches limned above retain their own individual strengths and their own individual weaknesses. Even the link made between Strauss and neoconservatism is not entirely unreasonable, providing one narrows their approach and focuses more on the ideational point of convergence in domestic politics and the influence Strauss has had on neoconservatives such as Irving Kristol. In the realm of American foreign policy, neoconservatives constitute a unique intellectual community. There are occasions when they appear to share liberalism's common assumptions just as there are occasions when neoconservatives appear to take their cues from foreign policy realists. But neoconservatives are neither idealists nor realists; they should be defined by the ideas they collectively espouse and trumpet. As moulders of public sentiment, as peddlers of ideas, neoconservatives must be taken seriously, even in the Obama era. Ideas, after all, may or may not rule the world. But they certainly influence those who live therein. 


\section{Chapter 3}

\section{Protecting the National Idea of America}

This chapter examines the neoconservative attempt to protect an idea. The idea itself is a distinctly American idea, one which holds that governments are instituted to secure the rights of the governed. The survival of this idea, according to neoconservatives, is indeed a vital national interest of the United States. When scholars and foreign policy-makers think in terms of the national interest, they are more than likely to think about it in similar terms to George Kennan, one of America's most famous diplomats and renowned practitioners of realpolitik: "the interests of the national society for which government has to concern itself," Kennan once argued, "are basically those of its military security, the integrity of its political life and the well being of its people" (Kennan, 1985/86). These needs, he hastened to add, "have no moral quality," for Kennan considered them to be "the unavoidable necessities of a national existence and therefore not subject to classification as either 'good' or 'bad'” (Kennan, 1985/86).

Kennan's argument emphasises the importance of the tangible interests which are often interpreted as the only national interests worth safeguarding and defending. To understand the neoconservative conception of the national interest, however, one has to have some appreciation of the way in which neoconservatives think about America, its principles, and its national mission. As Samuel Huntington observed, "National interests derive from national identity. We have to know who we are before we can know what our interests are" (Huntington, 2005: 10). Authors who examine America's national identity often begin by asking what is unique or exceptional about America, a question that has called forth no shortage of answers. ${ }^{72}$ This chapter, therefore, begins by inquiring into how neoconservatives think about America's national identity. What are their views on the nature of the American regime and its historic claim to uniqueness and exceptionalism? What aspect of American exceptionalism, in other words, do they endorse and celebrate as distinctly American? The answer, in short, rests upon the idea of natural rights and human rights.

\footnotetext{
${ }^{72}$ There is, as I explained earlier, a large amount of literature which has examined aspects of American exceptionalism. The two most frequently cited contributions include Hartz, 1955; and Hofstadter, 1948. For more recent studies, consult Huntington, 2005; Ignatieff, 2005; and Lipset, 1996.
} 
Defending the national idea is a core component of the neoconservative approach to American foreign policy. Therefore, this chapter begins by analysing the work of several prominent neoconservatives who have devoted considerable time to thinking and writing about America's national identity. I then explain how neoconservatives have attempted to protect the idea which is at the core of America's sense of nationhood. Regardless of whether it is their attempt to keep the idea from being misconstrued, or their attempt to remind Americans of its historical relevance, neoconservatives display an unflagging commitment to sustaining the core idea which nourishes the claim of American exceptionalism.

Although the national idea has inspired calls for greater action in a variety of strategic contexts, not all neoconservatives agree on what the national idea requires of America. Neoconservatives were certainly divided when it came to the Balkans in the 1990s. But no neoconservative questions the national idea's value or doubts its superiority. Indeed, seen from this perspective, America's most compelling national interest, according to neoconservatives, is clear: it is the defence and preservation of the liberal democratic idea.

\section{$\underline{\text { Neoconservatives and the National Idea of America }}$}

The idea that governments are instituted to protect the rights of the governed is the national idea of America, constituting a core part of the American creed. While it is an idea which the modern world arguably takes for granted, it is an idea which has had a profound affect on American political culture, fostering an intense suspicion of governmental authority. If the American government was incapable of protecting the rights it was instituted to secure, according to America's founding documents, citizens had a right to revolution. ${ }^{73}$ America's claim to exceptionalism, then, rested upon an experiment in popular government, a government in which the rights of the individual predominated.

That this interpretation of America's founding is shared and promoted by neoconservatives is seen in one of the most celebrated speeches ever delivered by Daniel Patrick Moynihan, the former Senator from New York whose fiery oratory throughout his tenure as Ambassador to the United Nations won him wide acclaim.

\footnotetext{
${ }^{73}$ I refer here to the American Declaration of Independence. For an elaboration on the American right to revolution, see Zuckert, 2001: 27-31.
} 
In what is arguably his most remembered performance, a performance which saw Moynihan speak out against the 1975 United Nations resolution equating Zionism with racism, Moynihan concluded by speaking about the importance of language and its capacity to shape ideas. He not only alleged that by equating Zionism with racism the United Nations had drained the word "racism" of all meaning; he went on to claim that this could have a very significant unintended consequence for those who approved of this resolution. If the United Nations, and the Third World countries supporting the resolution, began to strip words of their proper meaning, to what extent, Moynihan asked, could they legitimately invoke the language of "human rights" when they needed protection? (Moynihan 1975/1996: 96). Once the international community had sanctioned the misuse of language, the distortion of words, and redefined terms which had historically advanced the cause of the oppressed, there was no logical stopping point, Moynihan reasoned, from which one could step back and arrest the accompanying loss of faith in terms such as "human rights" and "self-determination" (Moynihan, 1975/1996: 98).

While Moynihan feared that the damage done to the idea and language of human rights could be "irreversible," he concluded his speech with a peroration emphasising not only the fragility of the idea of human rights, but the importance of the philosophy from which this idea was said to have emerged:

The idea of human rights as we know it today is not an idea which has always existed in human affairs. It is an idea which appeared at a specific time in the world, and under very special circumstances. It appeared when European philosophers of the seventeenth century began to argue that man was a being whose existence was independent from that of the State, that he need join a political community only if he did not lose by that association more than he gained. From this very specific political philosophy stemmed the idea of political rights, of claims that the individual could justly make against the State; it was because the individual was seen as so separate from the state that he could make legitimate demands upon it (Moynihan, 1975/1996: 98-99).

That the idea of natural rights and human rights is not barren of consequences for American foreign policy is a truism all neoconservatives would endorse. As Robert Kagan, one of the most prominent neoconservative foreign policy intellectuals whose 
work I discuss below, put it: "Every nation's foreign policy reflects the national idea, however that idea may be defined and redefined over time" (Kagan, 2006b: 42). America's national idea, according to Kagan, produced a different brand of nationalism, a brand that was produced not by a common ancestry, or an attachment to a common territory, but by a "common allegiance to the liberal republican ideology" (Kagan, 2006b: 42). Upholders and defenders of the national idea, from Jefferson and Lincoln to Truman and Reagan, have provided neoconservatives with a vast stockpile of quotes to call upon, all of which aim to render neoconservative writings consistent with America's heritage. In order to appreciate the extent to which neoconservatives dedicate themselves to protecting the national idea and combating the currents of thought which challenge it, it is necessary to examine the central purpose of two books, each written by a prominent neoconservative who has contributed significantly to foreign policy debates in America. Each book was written at a time when America faced different challenges in the world, and each book spoke of a different subject matter. Yet the two books converge in reinforcing the importance of the national idea to neoconservatives, bespeaking the lengths to which they are prepared to go in order to undercut the arguments of those who have either misconstrued the meaning of the national idea or denied its relevance throughout the course of American history.

\section{Carter's Human Rights Campaign}

Two books, one written by Joshua Muravchik and the other by Robert Kagan, amplify the way in which a concern with human rights has influenced neoconservative writings on American foreign policy. Joshua Muravchik, a former resident at the American Enterprise Institute who I interviewed in early 2007, has authored numerous articles and books on American foreign policy, and helped draft signal foreign policy addresses for presidential aspirants, most notably Bill Clinton in 1992. Muravchik's migration from left to right, from socialist to neoconservative, from a onetime Clinton supporter to a Bush enthusiast, epitomises much of the conventional wisdom relating to the intellectual metamorphosis through which one must supposedly go in order to be labelled a neoconservative.

In 1986, Muravchik published his doctoral dissertation, The Uncertain Crusade: Jimmy Carter and American Human Rights Policy (1986). Throughout the course of 
this work, Muravchik set out to critique the human rights policy of the Carter administration. Behind the critique, however, is a lingering concern shared by all neoconservatives, a concern relating to the vulnerability of the national idea. "In this age," Muravchik argued, "there is much less danger that the phrase, 'human rights,' will be forgotten or rejected than that its meaning will be lost" (Muravchik, 1986: 215). Such a danger, according to Muravchik, required the guardians of the national idea "to defend it against impostors and keep its meaning clear" (Muravchik, 1986: 215). This is the task Muravchik sets himself throughout this study and the premise upon which he constructs his critique of the Carter administration. It is a critique, in fact, with a conclusion that Muravchik states without a hint of equivocation: At the task of keeping the idea of human rights clear, he argued, "the Carter administration failed" (Muravchik, 1986: 215).

In order to support this conclusion, Muravchik propounded several arguments accusing the Carter administration of obscuring the meaning of "human rights," the purpose of which was to show that the administration's conception of human rights was not the "authentic" American conception. The Carter administration, he claimed, established a tripartite list of rights, the most novel of which was said to include a new category of rights labelled "violations against the integrity of the person," and the most unrealisable of which was said to include a host of economic and social rights (see Muravchik, 1986: 88-105). By elevating these categories of rights and relegating civil and political rights to the least important category of rights, the Carter administration was alleged to have de-emphasised the importance of the political freedoms and principles central to America's national identity. President Carter's eagerness to propitiate Communist regimes and evade charges of ethnocentrism, according to Muravchik, led to the elevation of categories of rights which only served to obfuscate "the very ideas it should have endeavoured to strengthen and clarify those of the Western human rights tradition" (Muravchik, 1986: 105).

Muravchik's critique of the Carter administration's human rights policy demonstrates the eagerness with which neoconservatives have sought to protect the national idea from misinterpretation. "The American approach to human rights," explained Muravchik, "emphasizes certain principles - freedom of expression and association, due process of law, government by the consent of the governed" (Muravchik, 1986: 227). These are the principles of political freedom held to be the sine qua non for the advancement of human rights. By inventing "novel" categories 
of human rights, the Carter administration was considered to be obscuring the very idea which had sustained America's claim to uniqueness. It is somewhat debateable, however, as to whether these categories of rights are that novel. They are frequently spoken about in the Universal Declaration of Human Rights, a document that America played a big part in drafting. ${ }^{74}$ Yet Muravchik's critique of the Carter administration reflects more than his concern with the way in which the administration addressed the issue of human rights; it reflects a profound faith in the primacy of ideas in international politics, a faith shared by all neoconservatives. As Muravchik put it, "the politics of the modern age are fought not only over territory and resources, and with missiles and factories, but over and with ideas - and human rights is the essence of the American idea" (Muravchik, 1986: 221).

\section{$\underline{\text { Dangerous Nation }}$}

If Muravchik sets himself the task of keeping the national idea from being misconstrued, Robert Kagan has consistently sought to remind Americans of its historical relevance. Kagan, a regular foreign policy commentator for the Washington Post and senior associate at the Carnegie Endowment for International Peace, is currently in the process of writing a two volume history on American foreign policy. While he has left behind a trail of articles and other widely read books on American foreign policy, his first volume in his most recent project, Dangerous Nation: America's Place in the World from Its Earliest Days to the Dawn of the Twentieth Century (2006b), is of immediate relevance.

It is within this volume that Kagan sets out to examine the history of American foreign policy, a history, according to Kagan, shaped by America's natural rights philosophy and the "universalistic nationalism" it produced (Kagan, 2006b: 42). America, in Kagan's presentation, was never the "isolationist exemplar" it is sometimes made out to be. It is, he argued, a country driven by an amalgam of ambitions and impulses, "idealistic as well as materialistic" (Kagan, 2006b: 6). It was these ambitions and impulses that were said to give rise to a penchant for a unique brand of liberal interventionism, a brand guided by a suspicion that the success of the American experiment in liberal republican government depended upon the

\footnotetext{
${ }^{74}$ For the definitive study on America's involvement in the drafting of this document, see Glendon, 2002.
} 
willingness of foreign peoples to assert their natural rights and construct a regime dedicated to their protection (see Kagan, 2006b: 42).

In this volume, Kagan questions the conventional historical interpretations of George Washington's Farewell Address and the famous admonition against foreign entanglements delivered by John Quincy Adams, each of which have been interpreted in a way that has lent credence to the notion that America is best served through the power of its example. ${ }^{75}$ Kagan's America, however, is not a languid exemplar, relying only on its example to inspire the world. He concludes his first volume on the history of American foreign policy by making a bold assertion: it is within the context of analysing the causes of the 1898 Spanish-American war that Kagan asserts that America has been more than willing to go to war to prevent human rights abuses in the world. Spanish oppression in Cuba, he argues, was the primary, though not exclusive, justification for a war fought for "humanitarian purposes" (Kagan, 2006b: 415). When John Hay, President McKinley's Secretary of State, called this war a "splendid little war," he meant, Kagan claims, "not only that the fighting itself had been splendid; so, too, he believed, were the goals and purposes for which the war was fought" (Kagan, 2006b: 415).

Kagan was aware that the ideational explanation for the 1898 war with Spain was not popular among scholars and historians, many of whom were said to consider the war as "unnecessary" or a product of war fever and mass "hysteria." "It is a commentary on our modern understanding of the behaviour of nations," Kagan replied, "that going to war for honor and in defense of abstract moral principles must be counted as either mad or disingenuous" (Kagan, 2006b: 414). Historians who attributed the conflict to some historical anomaly failed to understand, according to Kagan, the animating idea underlying the American regime and the national attachment to it. The war was said to be "a culmination, the not-illogical result of all that had come before it" (Kagan, 2006b: 416). One cannot understand what led America to war against Spain, in other words, unless one understands the history through which and the principles by which America defined itself as a nation. The war was not the exclusive product, Kagan argues, of imperialists bent upon national aggrandisement who manipulated a pliant populace to support American intervention.

\footnotetext{
${ }^{75}$ On Kagan's views on Washington's Farewell Address, see Kagan, 2006: 112-125. For his views on John Quincy Adams's warning not to go abroad in search of monsters to destroy, see Kagan, 2006: 160-169. For a conflicting interpretation on the views of America's founders, see McDougal, 1998.
} 
It was, he concluded, "the product of a universalist ideology as articulated in the Declaration of Independence" (Kagan, 2006b: 416).

Such an argument is meant to tell the reader something about America and its national identity, confirming in the process a thesis Kagan sedulously developed throughout this volume. When interacting with the world, Kagan's America could not ignore the status of the universal rights proclaimed by its leaders and celebrated by its people. Even when those rights were denied to slaves and women, exposing America to accusations of hypocrisy, the ideals, according to Kagan, always led Americans to a series of endless and disturbing questions relating to the national idea and their commitment to it:

If the rights of others were being trampled, Americans were forced to confront the question of whether they had an obligation to do something about it. Their answer might frequently be no - just as for seventy years most northerners chose to do nothing to eradicate slavery in the South. But the question itself, like the question of slavery, was hard to avoid (Kagan, 2006b: 46).

Seeing themselves as the custodians of the national idea, the likes of Muravchik and Kagan elevate the protection of the national idea to a vital national interest. It may be a national interest less concrete and less discernible than those national interests scholars regularly assess, but it is no less substantial. Both of the works examined above are attempts to clarify what it is America should stand for in the world. Such an undertaking required that America's founding principles and conception of human rights be demystified, a task undertaken by Muravchik. It also required, Kagan's work implies, an appreciation of the degree to which past American policy-makers have viewed the world through the prism of American principles and values. Both Muravchik and Kagan attempt to protect the national idea from misconception and historical neglect, but they are by no means the only attempts neoconservatives have made. Their rhetorical jousting with foreign policy realists, including their critiques of the realist conception of the national interest, is compelling evidence of their assumption that the national idea remains fragile, requiring a spirited and unstinting defence. 
$\underline{\text { Neoconservatives, Realists, and the National Interest }}$

Foreign policy realism is a school of thought renowned for emphasising the importance of stability, prudence, the balance of power, and the consequences of international anarchy. ${ }^{76}$ Its greatest exponents include E. H. Carr, Hans Morgenthau, Kenneth Waltz, Reinhold Niebuhr, George Kennan, and Henry Kissinger. While it is difficult to speak of the arguments promoted by these thinkers in general terms, all harbour concerns about the consequences of an unrestrained American idealism. "The intoxication with moral abstractions," declared Hans Morgenthau, "is indeed one of the great sources of weakness and failure in American foreign policy" (Morgenthau, 1951: 4).

Neoconservatives, though, depict the work of foreign policy realists as being out of touch with America. Their work, it is argued, reflects a profound ignorance about the degree to which the promotion of American values and ideals can sustain an effective foreign policy. Kagan, for instance, spent much of the 1990s questioning the realist conception of the national interest. ${ }^{77}$ "Past American Presidents and statesmen," he argued, "would never have imagined that the national interest, a term which could encompass our nation's noblest aspirations, would come to possess such a narrow and limited meaning as it does now" (Kagan, 1996a: 22). He objected strenuously to the argument put forward by George Kennan that the "state, as the people's agent, had no business expressing or reacting to 'moral impulses' in its calculation of the national interest" (Kagan, 1996a: 26). If "the state truly was the people's agent," Kagan rejoined, "it could not help reflecting their moral impulses" (Kagan, 1996a: 26). Kagan, unlike Kennan, did not see America’s "moral impulses" as something that should be tempered by "prudent" diplomats who could resist momentary whims and occasional calls for foreign entanglements that may undermine America's "true" interests.

As the 2003 Iraq War approached, neoconservative critiques of foreign policy realism continued apace. William Kristol and Lawrence Kaplan, a senior editor of The New Republic, co-authored The War over Iraq: America's Mission and Saddam's Tyranny (2003). Throughout this volume, realists, or the "unsentimental practitioners

\footnotetext{
${ }^{76}$ While foreign policy realists have produced a rich literature, there are useful summaries of this theoretical paradigm found in Baldwin, 1993; Donnelly, 2000; Haslam, 2002; and Smith, 1986.

77 To review Kagan's writings for Commentary throughout the 1990s, writings which I frequently call upon throughout this thesis, see Kagan, 1994; 1995a; 1996a; and 1997a.
} 
of realpolitik," as Kristol and Kaplan described them, are presented as the heirs of a European tradition that has introduced ideas deeply foreign to America's sense of national mission (Kaplan \& Kristol, 2003: 46). Kristol and Kaplan warn,

the brand of realism popularized in the United States after the Second World War and still in vogue today owes more to the unsentimental realpolitik practiced by nineteenth century European statesmen like Bismarck and Metternich - and articulated by their twentieth century heirs in Europe and in America - than it does to our Founding Fathers (Kaplan \& Kristol, 2003: 46).

By associating foreign policy realism with a brand of nineteenth-century European statecraft, neoconservatives seek to demonstrate that the ideas of foreign policy realists do not comport with the way in which America has historically conceived its interests and thought about its global responsibilities. It is a rhetorical strategy which endeavours to protect the national idea from the "corrosive" and "contaminating" influence of alien ideas transmitted from Europe by the likes of Hans Morgenthau and Henry Kissinger. To buttress their arguments, both Kagan and Kristol are quick to disinter the words of American icons who championed the national idea and advocated the need for an activist foreign policy, the purpose of which is to show how far adrift foreign policy realists are. Theodore Roosevelt, for instance, has been a favourite source. As Kristol and Kagan argued, "In insisting that the "national interest' extended beyond material security and prosperity, and in summoning Americans to seek honor as a nation, Theodore Roosevelt echoed the views of the American founding fathers" (Kristol \& Kagan, 2000: 24).

The division between neoconservatives and foreign policy realists is created by a core philosophical difference which has remained undetected, and insufficiently analysed, by much of the extant literature. It is a difference relating to how governments should be judged and the basis upon which governments should stake their claim to legitimacy. It is a difference leading neoconservatives to think in terms of "international duties" and realists to think in terms of "national survival" and "international restraint." To understand this difference, it is important to note that the unit of analysis for foreign policy realists is that of the state and the nation-state system, a system created by the Treaty of Westphalia in 1648. In his thoughtful history on foreign policy realism, Jonathan Haslam explained, "Common to all 
realists, consciously or not, is the notion of Reasons of State: the belief that, where international relations are concerned, the interests of the state predominate over all other interests and values" (Haslam, 2002: 17).

Reasons of State, according to Henry Kissinger, "asserted that the wellbeing of the state justified whatever means were employed to further it" (Kissinger, 1994: 58). What is important to note here is the emphasis placed upon the "wellbeing of the state." Foreign policy realists regularly speak as though the interests of the state, often defined in terms of "national survival," should be seen as distinct from the people who compose it. The legitimacy of the state, in the eyes of many foreign policy realists, is dependent upon its capacity to maintain its territorial integrity and preserve existing state institutions. It is no surprise to see those of a realist persuasion instructing America to "declare that it is committed to maintaining the territorial integrity of every state" (Walt, 2005: 242). Only cross border aggression, this argument implies, would constitute a sufficient threat to warrant considerations of American military intervention.

While realists see the legitimacy of the state as being dependent upon its capacity to defend its territorial integrity, neoconservatives see the legitimacy of the state as being dependent upon its capacity and willingness to secure the rights that government was instituted to secure. This significant divide is what accounts for the greater emphasis that neoconservatives place on the importance of individual rights. It is a divide best summed up by Joshua Muravchik when he asks,

is it morally wrong to intervene in the affairs of other nations in order to encourage respect for human rights? Only if the nation, rather than the human individual, is regarded as the ultimate moral unit. But by what logic does the nation have moral standing apart from that of the human beings who make it up? (Muravchik, 1986: 222).

According to Muravchik, to suggest that the nation has "moral standing apart from the human beings who make it up" is to make a suggestion which is at odds with the national idea of America. It is, in short, presented as a decidedly "un-American" suggestion. Muravchik continued: 
The American approach to human rights rests on certain premises about the nature of man and the primacy of the individual over the state; and it emphasizes certain principles - freedom of expression and association, due process of law, government by the consent of the governed (Muravchik, 1986: 227).

Muravchik's concerns with human rights are very much shaped by liberal and Enlightenment ideas, ideas emphasising the importance of the individual retaining an ascendant position in a national society; ideas that consider it the responsibility of government to secure inalienable human rights; and ideas that do not consider state sovereignty to be an inviolate right with little consideration given to a state's internal conduct and form of government.

Ignoring the concerns neoconservatives express in relation to the fate of human rights in the world leads one to run the risk of not only failing to understand an important aspect of the neoconservative approach to American foreign policy, but also of failing to understand one of the sources of neoconservatism's appeal, especially among segments of the left identified as "liberal hawks" and among IR theorists described as "humanitarian interventionists."78 It was not uncommon, for instance, in the lead up to the 2003 Iraq War to find leftist intellectuals and writers such as Christopher Hitchens and William Shawcross expressing support for neoconservative concerns with the fate of human rights in the world. ${ }^{79}$ Reflecting on his time observing the genocide in the Balkans throughout the 1990s, Hitchens explains, "That war in the early 1990s changed a lot for me. I never thought I would see, in Europe, a full-dress reprise of internment camps, the mass murder of civilians, the reinstitution of rape and torture as instruments of policy" (cited in Murray, 2006: 77).

Throughout this period Hitchens became acquainted with several neoconservatives who shared his concern for the fate of Bosnian Muslims. "I was signing petitions in favour of action in Bosnia," he explained, "and I would look down the list of names and I kept finding, there's Richard Perle. There's Paul Wolfowitz. That seemed interesting to me. These people were saying we had to act" (cited in Murray, 2006: 77). It is not unusual to hear the arguments of Hitchens echoed by

\footnotetext{
${ }^{78}$ For two studies that emphasise this convergence, see Rieff, 2006: pp. 157-173; and Smith, 2007: Ch. 6.

${ }^{79}$ For an elaboration of the views of these two writers see Hitchens, 2003; and Shawcross, 2004. One will find not only a defence of the Iraq War, but sympathetic portrayals of neoconservative ideas, especially those relating to human rights and democracy promotion.
} 
neoconservatives such as William Kristol. In fact, both Hitchens and Kristol often identify and denounce that segment of the left which continues to oppose the employment of American power in virtually all circumstances, of which Michael Moore and Noam Chomsky would be fitting representatives. Hitchens, while delivering one of his inimitable rhetorical tirades, expresses considerable disillusionment with his erstwhile leftist allies when it came to their response to the terrorist attacks on September 11, 2001:

The United States was attacked by theocratic fascists who represent all the most reactionary elements on earth. They stand against everything the left has fought for: women's rights, democracy. And how did much of the left respond? By affecting a kind of neutrality between America and the theocratic fascists" (Hitchens, 2004).

When I interviewed Kristol, he was quick to echo a similar theme, arguing that since governments such as the Taliban are not exactly renowned for their support for minority rights, one would not expect the left to have much "fondness for Islamic jihadism" (Kristol, interview, 21 February 2007). In their rush to align themselves with America's adversaries, Kristol implied, the far left regularly ignored and subverted the very principles they ostensibly espouse, principles which neoconservatives now present themselves as the last remaining defenders of. The national idea, according to neoconservatives, is threatened as much by those who proclaim some residual or supine commitment to it, vaguely defined as the far left, as it is by those wily European realists who, in the neoconservative presentation, hope to supplant it. Regardless of whether this is an accurate depiction of the left, the neoconservative elevation and privileging of human rights concerns undoubtedly reflects an attachment to America's founding liberal ideals. It is a reflection also of an eagerness to serve as the watchful guardians of the national idea, the survival of which, neoconservatives believe, is by no means assured.

\section{The Balkans and Beyond}

The neoconservative attempt to revitalise the national faith in the national idea was greatly assisted by the end of the Cold War. The national idea, at its core, suggests 
that governments should be judged upon the basis of their effectiveness in securing individual human rights. Yet there is a much larger international context within which this argument is made, one which has not always been as receptive to such an argument as it now is. The current international system is predicated upon principles of non-intervention and state sovereignty. They are principles which find their clearest expression in Article 2 (4) of the United Nations Charter, principles prohibiting member states from intervening in the domestic affairs of others. It is an article worth quoting in its entirety:

All Members shall refrain in their international relations from the threat or use of force against the territorial or political independence of any state, or in any other manner inconsistent with the purposes of the United Nations Charter. ${ }^{80}$

While still considered the central pillars of the current international system, the principles of non-intervention and state sovereignty were called into greater question throughout the 1990s as some members of the international community began to accommodate themselves to the notion that sovereignty is as much a responsibility as it is a right. As Alynna Lyon and Chris Dolan argue in a thoughtful essay on American humanitarianism, "With the collapse of the Soviet Union humanitarian intervention became an important pillar in the emerging new world order" (Lyon \& Dolan, 2007: 46). It was certainly a pillar arousing the interest of many thoughtful scholars, not to mention a diverse array of international leaders, including Kofi Annan, the former Secretary-General of the United Nations. From Samantha Power's indignant critique of America's response to the twentieth century's most horrific genocides to Nicolas Wheeler's thoughtful examination on the evolution of the norm of humanitarian intervention, commentators and scholars were eager to analyse the way in which America and the international community responded to state sanctioned genocide (see Power, 2003; and Wheeler, 2002).

This was, in other words, a propitious time to be arguing for greater global activism and the need for the adoption of a foreign policy dedicated to ending human rights abuses in the world. Faith in the national idea of America, in fact, was being

\footnotetext{
${ }^{80}$ Citations of the United Nations Charter have been taken out of War Law (2005), a book in which the Charter is reprinted in its entirety. See Byers, 2005: 156-185.
} 
reinvigorated by a debate at the international level, a debate which questioned the limits of state sovereignty and asked when the international community could legitimately involve itself in the affairs of other nations. For neoconservatives, the flashpoint was Bosnia. Bosnia issued a stern challenge to America's moral sensibilities, testing America's post-Cold War commitment to the national idea. Upon what basis, scholars and commentators asked, should Milosevic's deeds be judged? Would his deeds be judged on the basis of the adverse impact they could have on the Atlantic Alliance? Or would they be judged on something more abstract, something relating to the national idea and the American commitment to it? Some neoconservatives felt so strongly about Serbian aggression in Bosnia that they distanced themselves from the first Bush administration, endorsing then-Governor Clinton in the 1992 presidential election. Muravchik explained, "On what I care about - human rights and promoting democracy, keeping some sense of ideals in our foreign policy - Clinton is more amenable than Bush" (cited in Murray, 2006: 74).

While neoconservatives would become as disillusioned with President Clinton as they did with President George H. W. Bush, the ethnic conflict in the Balkans provided them with an opportunity to re-think America's international responsibilities in the post-Cold War world. For leftist critics such as Noam Chomsky, American intervention in Bosnia was about little more than the extension of American power and the consolidation of America's role as leader of Europe and NATO (Chomsky, 2003: 53-59). Chomsky, of course, was hardly propounding a novel argument, for it is often an article of faith among scholars that the will to power is inescapable, both for the individual and the nation-state. The sway that an idea can have over the minds of men is easily forgotten and just as easily dismissed as mere window dressing, something masking only a crass national interest. The basis for such an assumption, however, is not always well explained. As the French political and social theorist Raymond Aron once argued, there are times when "the triumph of the faith, the spread of an idea, may be conceived, in all sincerity, as the true goal of action" (Aron, 2003: 75).

Motives, of course, are always complex. When it came to Bosnia, neoconservatives mobilised a diverse array of arguments justifying intervention and greater action. Their writings, infused with a mix of genuine moral outrage at Serbian depredations and a deep concern over the way in which a feckless response could adversely impact America's ongoing commitment to stability in Europe, almost 
always emphasised Serbian human rights violations as a compelling casus belli. As Muravchik put it,

Weighty matters are at stake in the Bosnian crisis. The first is humanitarian. Serbian forces are waging a war against civilians. Contemptuous of the laws of war, they are targeting hospitals, old age homes, and breadlines (Muravchik, 1992: 34$){ }^{81}$

No nation can intervene everywhere, Muravchik realised, but he still called for America to protect those subjected to the most bestial forms of state sanctioned violence. "Our duties to people in other countries are less compelling than our duties to our fellow citizens," he argued, "just as our duties to the latter are less urgent than those to our families and dependents. But that does not mean they are nil" (Muravchik, 1992: 37). There is a tipping point, according to Muravchik, when interventions for reasons of unadulterated altruism become both necessary and just. "At some extreme point, humanitarian abuses in themselves do warrant intervention," he believed (Muravchik, 1992: 34).

As the 1990s progressed and the international community moved from witnessing one of the most indisputable instances of genocide in Srebrenica, Bosnia, to viewing the large scale ethnic cleansing in Kosovo, the patience of neoconservatives so far as negotiating with Milosevic was concerned all but evaporated. The Project for a New American Century delivered a letter, signed by the likes of William Kristol, Robert Kagan, Paul Wolfowitz, and Richard Perle, to President Clinton, insisting that America could not expect "peace and stability in the Balkans so long as Milosevic remains in power" (Letter to President Clinton on Milosevic, 1998). The signatories went on to declare:

We understand that the United States has sought and on occasion achieved Milosevic's cooperation in carrying out the Dayton settlement; and there is no guarantee that a successor to Milosevic will be significantly more committed to peace. Nevertheless, we believe the time has come for the United States to

\footnotetext{
${ }^{81}$ Muravchik insisted that since Bosnia had been recognised as a state by the United States and the United Nations, Serbian aggression against it constituted "cross border aggression" and thus provided a compelling legal justification for greater involvement (see Muravchik, 1992: 35).
} 
distance itself from Milosevic and actively support his replacement by a democratic government committed to ending ethnic violence. Our 'pact with the devil' has outlived whatever usefulness it once had (Letter to President Clinton on Milosevic, 1998).

While neoconservatives became frustrated with the Clinton administration's "desultory" responses to the conflicts in the Balkans, they became as equally frustrated with the way in which the Clinton administration prosecuted the conflicts it "belatedly" waged. Not only should America concern itself with human rights abuses in the world, it should also, Max Boot argued, be prepared to risk the lives of its servicemen and women to safeguard the rights of those subjected to internal persecution. In his commentary on the war in Kosovo, Boot complained, "While NATO pilots were flying out of anti-aircraft range, the Kosovars they were supposed to be protecting were at the mercy of Serb ethnic-cleansing squads" (Boot, 2003: 326). "It is a curious morality," he added with both exasperation and bewilderment, "that puts greater value on the life of even a single American pilot - a professional who has volunteered for combat - than on hundreds, even thousands of Kosovar lives" (Boot, 2003: 326).

As I explain below, Bosnia in some ways shaped the neoconservative response to Iraq. It was, for many neoconservatives, the most important foreign policy issue to have emerged throughout the 1990s. They began to talk about enforcing a regime change in the Balkans, calling on the Clinton administration to replace Milosevic with "a democratic government committed to ending ethnic violence" (Letter to President Clinton on Milosevic, 1998). This is not to suggest that neoconservatives did not emphasise other arguments justifying American intervention in Bosnia and Kosovo. But it is to suggest that when neoconservatives were confronted with the disquieting prospect of large scale abuses of human rights occurring in the era of American military preponderance, more was considered to be at stake than stability in Europe, as important as that was and is. It was simply not honourable national conduct, Kristol and Kagan declared, to sit "atop a hill" and lead "by example" (Kristol \& Kagan, 1996). Such inaction, they concluded, may even be a result of a "deeper form of self loathing" (Kristol \& Kagan, 1996). It may, in other words, reflect not only a loss of faith in the national idea, but an abject negation of it. 
$\underline{\text { Reconciling Ideals with Interests }}$

However great the neoconservative attachment to America's founding liberal principles, one must probe a little deeper into the way in which neoconservatives speak of the "national interest." Neoconservatives are acutely aware of what John Kane has called the "persistent moral dilemma" of American foreign policy, the dilemma of reconciling ideals with interests, power with virtue, and a concern for the fate of human rights in the world with the burdens this imposes (see Kane, 2007). Kagan showed considerable awareness of this dilemma when he wrote his first volume analysing the history of American foreign policy. "The true American mission," he argued, "was a ceaseless effort to reconcile universal principle and selfish interest" (Kagan, 2006: 46). When it came to explaining how Americans had historically attempted to reconcile "universal principle" and "selfish interest," Kagan explained, "Often Americans insisted or wanted to believe that principle and interest were entirely compatible, as sometimes they could be" (Kagan, 2006: 46). What he did not say in this volume, however, was that this was the way in which he and several other neoconservatives had attempted to solve a dilemma that has long been a source of considerable academic analysis. ${ }^{82}$

When Kagan writes as a policy advocate - not a detached commentator analysing the history of American foreign policy - he, along with William Kristol, regularly employs the above argument, insisting that America's "moral goals and fundamental national interests are almost always in harmony" (Kristol \& Kagan, 1996). The argument is applied to whatever the most pressing foreign policy issue of the day may be, from Bosnia to Iraq to Darfur. ${ }^{83}$ Rarely do neoconservatives recommend a course of action without explaining how American intervention serves American interests. In one sense, this is a commonsensical approach whereby writers couch arguments in a way that can appeal to as wide an audience as possible. Furthermore, as Richard Crockatt points out, “There is not and never has been a simple either/or - realism or

\footnotetext{
${ }^{82}$ For an older, but still relevant, study on this topic, see Osgood, 1953.

${ }^{83}$ One can go back to the 1980s, for example, and find Muravchik questioning the arguments of those who proclaimed that a consistent policy of advancing human rights around the world may conflict with other national interests. The "advancement of human rights," he responded, "almost always serves concrete interests, both because it is a victory for our system of values and because every country in the world where human rights flourish is friendly, some of course more than others, to the United States" (Muravchik, 1986:225). For a more recent example relating to how both American ideals and interests are at stake in Darfur, Western Sudan, see Kristol \& Serchuk, 2004.
} 
idealism - in the making of American foreign policy but rather various complex mixtures of the two" (Crockatt, 2006: 128). Bosnia, for instance, certainly provided neoconservatives with an opportunity to mobilise public sentiment behind a policy that both punished human rights violators and reaffirmed America's commitment to stability in Europe. For instance, when explaining what was at stake in Bosnia, Kagan claimed,

For the United States as a world power, the problem of Bosnia is, and always has been, about more than Bosnia. It has been about America's will and capacity to use its power effectively to maintain a stable and secure Europe, which in turn is the essential foundation for maintaining a world order conducive to American interests and ideals (Kagan, 1995b).

There are several rhetorical flourishes, however, which tend to suggest that neoconservatives such as Kristol and Kagan, while genuinely believing that the promotion of American ideals can serve American interests, also employ this argument to gain the approval of a wider audience who do not share their zeal for meddling in the affairs of other nations. Scholars often assume that idealistic rhetoric masks the pursuit of narrower national interests. Rarely is it argued, however, that interests can be identified or accentuated in order to sustain and advance an idea. Defending their support for the 2003 Iraq War, Kristol and Kagan responded quite forcefully to critics who objected to the use of force against Iraq on pure humanitarian grounds, even registering a disagreement with Paul Wolfowitz. The passage is worth quoting at length, for it not only suggests that Kagan and Kristol may search for interests that are consistent with national ideals; it also underscores the degree to which neoconservative arguments in relation to Bosnia and Milosevic shaped the way in which some neoconservatives viewed Saddam's Iraq:

It is fashionable to sneer at the moral case for liberating an Iraqi people long brutalized by Saddam's rule. Critics insist mere oppression was not sufficient reason for war, and in any case that it was not Bush's reason. In fact, of course, it was one of Bush's reasons, and the moral and humanitarian purpose provided a compelling reason for a war to remove Saddam. It should certainly have been compelling to those (like us) who supported the war on Slobodan Milosevic a few 
years ago. In our view - and here we disagree with what Paul Wolfowitz said to Vanity Fair a few months ago - liberating the Iraqi people from Saddam's brutal, totalitarian dictatorship would by itself have been sufficient to remove Saddam (emphasis added) (Kagan \& Kristol, 2004a).

It is surely interesting to note that, notwithstanding regular proclamations of how instrumental the promotion of American ideals can be to the securing of broader strategic objectives, in this passage the promotion of American ideals becomes an end in itself. This is the only instance in which I have discovered that Kagan and Kristol assert so unequivocally that the promotion of American ideals is a worthy national objective independent of whether the recommended course of action serves American interests, narrowly defined. As seasoned foreign policy commentators, Kristol and Kagan appreciate that America has rarely employed its power with the sole aim of ending human rights abuses. As Samantha Power put it in her critique of America's dilatory responses to the genocides of the twentieth century, "No U.S. president has ever made genocide prevention a priority, and no U.S. president has suffered politically for his indifference to its occurrence" (Power, 2003: xxi). This is one reason why Kristol and Kagan so regularly insist that the promotion of American ideals and values serves American interests. It is, at least in part, an attempt to persuade policy-makers not to overlook the principles upon which America was founded, and the idea which has sustained America's historic claim to uniqueness and exceptionalism. It is, in other words, just as much an attempt to preserve the national idea as it is an attempt to define American interests.

By insisting that the promotion of American ideals can serve American interests, Kagan and Kristol are employing an argument at odds with some of the key assumptions of foreign policy realists, most notably the assumption that ideals and interests can and should remain separate domains of statecraft. Not only, for instance, are the ideas of foreign policy realists presented as European imports; they are also accused of undermining the ends they hope to serve. As Kagan argued,

During the Cold War, Americans derived enormous strength and even a measure of consistency from their steady belief that freedom, democracy, capitalism, the rule of law, and the right to self-determination were the aspirations of all peoples everywhere, and that Communism and dictatorship were the enemies of those 
aspirations. It was indeed their 'moral impulses' that enabled Americans to appreciate the need for maintaining a military presence in Europe, for resuscitating European and Asian economies, and for playing the international role which realists like Kennan deemed essential (Kagan, 1996: 26).

If realists did not appreciate the role American ideals played in America's confrontation with the Soviet Union, it was a tendency, according to Kagan, carried over into the 1990s. As peripheral conflicts and intra-state violence in Somalia, Haiti, Rwanda, and Bosnia, came to dominate the headlines of the post-Cold War world, Kagan took exception to those who argued that a preoccupation with peripheral conflicts would lead America to neglect its core security interests. ${ }^{84}$ Citing several historical case studies from the period which preceded the Second World War, Kagan made the opposite argument. From Italy's invasion of Ethiopia to Japan's conquest of Manchuria, these seemingly peripheral conflicts were ignored by America and the international community, thus inducing a sense of complacency and torpor that was said to have led to a failure to confront the bigger threat when it finally made its appearance at Munich (see Kagan, 1994: 43). "Once appeasing adversaries and wishing away problems becomes a habit," Kagan explained, "it becomes a hard habit to break" (Kagan, 1994: 43). Global activism on the part of the United States, this argument implied, was seen as the best way of manufacturing the will to use force when the big challenges emerged. America, Kagan argued, could not afford to wait for the arrival of the next Soviet Union or Nazi Germany, for "the tests of American strength, character, and endurance, essential to the preservation of a more stable world order, will continue to come in such unlikely places as Bosnia, Haiti, Somalia, and Korea” (Kagan, 1994: 43).

Kagan was not the only neoconservative to see American resolve stiffened by an activist foreign policy. Far from degrading the "combat capability" of American troops, peripheral conflicts requiring the deployment of limited numbers of troops to police peace accords, punish human rights violators, or launch "punitive raids" against international malefactors could, argued Max Boot, enhance their war fighting capabilities (Boot, 2003a: 342-343). What these neoconservatives appeared to be saying was that if America is required, at some future date, to employ the proverbial

\footnotetext{
${ }^{84}$ Specifically, he was taking aim at an argument made by Fareed Zakaria. See Zakaria, 1993.
} 
sword and fight wars in the national interest, then America must be prepared to sharpen the blade by fighting wars on the periphery, wars aiming to prevent genocide and alleviate human suffering. By making American readiness to fight the big wars necessary for national survival dependent upon America's willingness to stand up for its principles around the world, the likes of Kristol, Kagan and Boot were offering strategic rationales for a foreign policy imbued with American idealism.

One is entitled to question, though, whether the attempt to make American interests compatible with national ideals will always produce a rational calculation of interests. Even if one finds the neoconservative attempt to protect the national idea an admirable undertaking, as I do, there are troubling questions that go unanswered. Given the enthusiasm displayed by neoconservatives such as Kristol and Kagan for humanitarian interventions, one would expect them to develop criteria alerting policymakers to when such interventions could take place. "It is easy to say that the United States must have criteria for choosing when to intervene," Kristol and Kagan argue. "But it is a good deal harder to formulate those criteria than simply to say they must exist" (Kristol \& Kagan, 2000: 13). Surely, however, the difficulty of the task is not a licence to evade it. Surely, in other words, those who are committed to ending human rights abuses in the world should develop actionable criteria alerting policy-makers to when America could intervene in the affairs of other nations with the intent of ending intra-state violence. Even Henry Kissinger, someone who is not the strongest partisan for such interventions, enumerates four principles which should be met before America commits itself to a specific course of action (see Kissinger, 2002: 256-273). It is interesting to note that in Present Dangers: Crisis and Opportunity in American Foreign and Defense Policy (2000), an edited collection of essays assembled by Kristol and Kagan in the run up to the 2000 election, the problem of humanitarian intervention is overlooked and seldom spoken of.

A rhetorical commitment to preserving and protecting the national idea is a commitment worthy of endorsement. The policy implications of such a rhetorical undertaking, however, are less clear. Kristol and Kagan insist that America cannot “embark on a crusade against every dictatorship," but their writings provide little guidance as to which dictatorships America should "crusade" against (Kristol \& Kagan, 2000: 13). As it is, Kristol and Kagan are prone to support any intervention 
with the aim of ending human rights abuses in the world. ${ }^{85}$ Such peripheral entanglements, one could argue, are likely to breed considerable domestic disillusionment, especially when those one is attempting to assist appear less than supportive of the intervention. One need only think of the adverse domestic reaction to America's intervention in Somalia in 1993, an intervention, following a switch in objectives from famine relief to nation-building, culminating in the deaths of eighteen American soldiers, one of whom was dragged through streets of Mogadishu amidst ebullient Somalis. As David Halberstam put it,

No sight could have been more bitter for ordinary Americans sitting at home to witness: the body of a dead soldier, who had gone so far away on a humanitarian mission, being dragged through the streets, while the people he was there to help cheered his desecration (Halberstam, 2002: 262).

The American people, like people of all nations, do not have an inexhaustible supply of human compassion which compels them, irrespective of risk, to alleviate the suffering of others. "However general the obligation to affirm universal human rights," argued Cliff Orwin in his thoughtful writings on the limits of human compassion, "a government's duty to risk the lives of its citizens to secure those rights for strangers - in effect the duty to police the world - will always remain debateable" (Orwin, 1996: 49). ${ }^{86}$ It is a peculiar aspect of human nature that communal attachments are often stronger and more solidified than any cosmopolitan identification with those beyond one's borders. Of course, as Kagan rightly argues, the universalistic nationalism spawned by an ideology asserting the timeless validity of "self-evident truths" has somewhat mitigated this tendency in America. However, by criticising those Americans who argued, following the 2003 Iraq War, that the Iraqi people had done too little to justify an indefinite American occupation, Kagan himself demonstrated that there are limits to the sacrifices a national populace is willing to sanction, even the most idealistic of populaces (see Kagan, 2007a).

Those dedicated to an idea or a faith must weigh the ideational consequences of the policies they advocate and the interests they define, for ideas can lose their allure

\footnotetext{
${ }^{85}$ Kristol, in fact, told me in our interview that he wished America was more proactive and less hesitant in toppling dictators around the world.

${ }^{86}$ For a useful philosophical discussion of the so-called "CNN" factor and the limits of human compassion, see Orwin, 1996; and 1997: Ch. 14.
} 
not only because they were successfully challenged by opposing ideational forces, but because of the direction in which their paladins take them. A statesman, Stanley

Hoffman argued, must be "concerned with consequences," especially "because of the bad results a neglect of consequences might have for his creed" (Hoffman, 1981: 29). If the national idea is to be protected, it deserves a responsible defence from foreign policy intellectuals willing to set perimeters upon American interventions. In fact, one could argue in the spirit of Kagan's criticism of foreign policy realists that the Kristol-Kagan eagerness to protect the national idea through the means of a conception of the national interest which demonstrates the importance of a valuesladen foreign policy will subvert the ends it proclaims to serve. It will, in other words, lead to military entanglements that diminish whatever domestic consensus exists for a foreign policy dedicated to sustaining the national idea, both in the hearts and minds of Americans and those abroad.

\section{Democratic Globalism, Democratic Realism and the National Interest}

Not all neoconservatives are as willing to go as far as Kristol and Kagan in calling for a globally active foreign policy. Charles Krauthammer, a former Democratic speechwriter for Walter Mondale turn neoconservative intellectual, delivered a speech at the American Enterprise Institute in 2004, identifying two strands of neoconservatism. He attempted to draw, he explained elsewhere, "a distinction between a more expansive and more restrictive neoconservative foreign policy" (Krauthammer, 2005: 24). Krauthammer labelled the more expansive neoconservative foreign policy approach "democratic globalism," an approach associated with the likes of Robert Kagan, William Kristol, William Bennett, Joshua Muravchik and Max Boot (Krauthammer, 2004). He labelled the more restrictive neoconservative approach to American foreign policy, an approach Krauthammer identified with, "democratic realism" (Krauthammer, 2004). The democratic globalist and democratic realist point of divergence centred upon a dispute emerging in the wake of the Cold War over the degree to which the national idea required and compelled global activism. Neither strand, however, questioned the worthiness of the national idea or doubted that it was worth defending.

Some of the criticisms levelled at the democratic globalist strand of neoconservatism have, either implicitly or explicitly, been levelled by 
neoconservative democratic realists such as Krauthammer. While not all neoconservatives would recognise this label or embrace it, Krauthammer's division of neoconservatism does serve as a potent analytical tool enabling one to discriminate between two strands of neoconservatism which do not always agree on what the national idea requires of America, especially in times when it is not challenged by ideas embedded in rival ideologies capable of commanding the loyalties of a significant portion of the earth's surface. "The danger of democratic globalism," Krauthammer warned, "is its universalism, its open-ended commitment to human freedom, its temptation to promote the flag of democracy everywhere. It must learn to say no" (Krauthammer, 2004). Krauthammer, as his writings throughout the 1990s showed, was more than willing to say "no," opposing many, if not all, of the interventions the likes of Kagan, Kristol and Muravchik supported. From Haiti to Bosnia to Kosovo, Krauthammer resisted the temptation to call for what he considered to be the capricious use of American power. ${ }^{87}$

Sharing Krauthammer's reluctance to employ American power in pursuit of illdefined ends, democratic realists, which includes, I argue, Paul Wolfowitz and Jeane Kirkpatrick, are much quicker than their counterparts to speak of the difficulties of successful democratisation and nation-building. They are more likely to assert, as Wolfowitz has, that America "cannot ignore the uncomfortable fact that economic and social conditions may better prepare some countries for democracy than others" (Wolfowitz, 2000: 320). Kirkpatrick, as most readers of her widely read 1979 Commentary article, "Dictatorships and Double Standards," would know, exhibits considerable scepticism towards the prospects of successful democracy promotion in the world. The belief "that it is possible to democratize governments, anytime, anywhere, under any circumstances," was one which Kirkpatrick did not share (Kirkpatrick, 1979/1982: 30). "This notion," she concluded, "is belied by an enormous body of evidence based on the experience of dozens of countries which have attempted with more or less (usually less) success to move from autocratic to democratic government" (Kirkpatrick, 1979/1982: 30).

Kirkpatrick's scepticism about the prospects of successful democracy promotion culminates in her posthumously published book, Making War to Keep Peace (2007).

\footnotetext{
${ }^{87}$ For a sampling of the articles Krauthammer wrote throughout the 1990s, articles in which he explains his reasoning for opposing American interventions in Haiti, Bosnia, and Kosovo, see Krauthammer, 1993a; 1993b; 1994a; 1994b; 1999a; 1999b; and 1999c.
} 
In this study, Kirkpatrick analysed American foreign policy in the post-Cold War world, questioning whether countries such as Haiti and Iraq were countries amenable to democratisation. President Bush's decision to remove Saddam Hussein in 2003 was, she explained, "a decision which troubled me deeply” (Kirkpatrick, 2007: 279). While Wolfowitz and Kirkpatrick would take different views of the 2003 Iraq War, one should not overlook their many agreements, often expressed in their opposition to the Clinton administration's "over-reliance" on American power in pursuit of what they considered to be broadly defined strategic objectives. "The occupation in Haiti," Kirkpatrick explained, "showed that our government had become too casual about using military force, deploying U.S. troops, and assuming open-ended obligations" (Kirkpatrick, 2007: 152).

By intervening in countries peripheral to America's core interests, policy-makers, according to Wolfowitz, ran the risk of entangling America in intractable intra-state conflicts that eventually tempt policy-makers to withdraw American power, falsely believing that since "marginal regions are marginal," American power could be withdrawn without consequence (Wolfowitz, 1994). Wolfowitz objected strenuously to this belief, arguing, "the ability of the United States to use force effectively wherever it decides to do so - is itself a major interest of this country" (Wolfowitz, 1994). "Perceived American weakness in the 'unimportant' arenas of Somalia and Haiti," he explained, "could lead to a catastrophic misjudgement of U.S. intentions in East Asia" (Wolfowitz, 1994). As I argue in a later chapter, averting great power war was a central concern of Wolfowitz's, and a central concern of the documents he helped draft in the early 1990s.

One should note that there is considerable tension between Kagan's claim - that America must intervene in peripheral conflicts to help prepare for the big challenges and that of Wolfowitz's - which states quite clearly that an excessive preoccupation with peripheral conflicts may contribute to the arrival of the big challenges. There is considerable tension, in short, between some of the arguments of democratic realists who cautioned restraint in the 1990s, and democratic globalists who bemoaned the Clinton administration's lack of resolution. These are substantive differences, to be sure, but both strands of neoconservatism, I believe, are defined more by what unites them than what divides them. 


\section{Protecting the National Idea, the Unifying Thread}

Despite the existence of substantive differences between the two strands, one should be careful not to overstate the degree to which these differences obscure shared philosophical premises. It would be a mistake to assume that opposition or caution expressed in relation to various interventions throughout the 1990s, or opposition or caution expressed in relation to the 2003 Iraq War (Kirkpatrick), disqualifies one from the ranks of neoconservatism. As I explained in an earlier chapter, Charles Krauthammer's opposition to the humanitarian interventions of the 1990s led Steven Hurst to describe him as a "conservative nationalist," a category considered to be distinct from neoconservatism. ${ }^{88}$

Such a portrayal, however, fails to appreciate the distinctiveness of neoconservatism. To understand why Krauthammer opposed American interventions throughout the 1990s in regions considered peripheral to America's core interests, one needs to consult the articles Krauthammer authored throughout the period of the thenincipient collapse of Soviet communism. In addition to the many similarities discussed in the following chapters, it becomes clear, after reading these articles, that one unifying thread tying neoconservative intellectuals together is their desire to protect the national idea. In one article, Krauthammer argued,

During the Cold War, the United States has been involved in a struggle to preserve a structure of freedom in the world. The necessary condition for what JFK called 'the success of liberty' was the defeat of those great forces - fascism and communism - which threatened the very idea of freedom and had the power and will to execute the threat. By winning these victories, the U.S. has, literally, made the world safe for democracy" (emphasis added) (Krauthammer, 1989/1990: 47-48).

What is important to note in the foregoing passage is the emphasis Krauthammer places on the "idea of freedom," an idea pitted against those rival ideas embedded in

\footnotetext{
${ }^{88}$ Steven Hurst, it should be recalled, argues that the neoconservative influence on the Bush administration is overstated. He employs criteria to distinguish between conservative nationalism, which is said to have been quite influential and within which Krauthammer is placed, and neoconservatism, the influence of which was said to be exaggerated and within which the likes of William Kristol, Robert Kagan, and Joshua Muravchik are placed. See Hurst, 2005.
} 
the ideologies of fascism and communism. Once the Cold War concluded, America, according to Krauthammer, could accept a certain level of "ideological repose," resting comfortably in the realisation that the disintegration of the Soviet Union spelled the end of a geo-political and an ideological struggle which had lasted over four decades (Krauthammer, 1990/1991: 29). The "responsibility to make democracy possible was a historical absolute," explained Krauthammer (Krauthammer, 1989/1990: 48). "The responsibility to enact the next stage - to make democracy actual in every corner of the globe - is less controlling" (Krauthammer, 1989/1990: 48). What was required of America throughout the Cold War, in other words, was the protection and triumph of an idea capable of sustaining the American way of life and eviscerating the ideological pretensions of the Soviet Union. Once achieved, not all neoconservatives would see the need for a level of global activism that matched that of the Cold War.

While Krauthammer was extremely reluctant to see America involved in the peripheral conflicts of the 1990s, others such as Wolfowitz and Kirkpatrick who shared Krauthammer's scepticism about such projects were still prepared to offer minimal assistance to those subjected to internal persecution. They may not have gone as far as Kristol and Kagan, but the national idea, according to these thinkers, did require a degree of activism.

In a statement all neoconservatives would endorse, Paul Wolfowitz argues, "the desire of people to be free and to choose their own leaders is one of the most powerful forces in the world" (Wolfowitz, 2005). For Wolfowitz, this is a statement which carries just as much practical import as it does rhetorical punch. "Nothing could be less realistic," he explained, "than that version of 'realism' that dismisses human rights as an important tool of American foreign policy" (Wolfowitz, 2000: 319). It is a "tool," Wolfowitz added in his writings before the 2003 Iraq War, because "refusing to arm our friends, whether in Bosnia or Cambodia or Iraq, is a strategic as well as a moral mistake" (Wolfowitz, 2000: 323). Victims who live under the quotidian oppression of a ruling dictator and aggressor, according to thinkers such as Wolfowitz and Kirkpatrick, may not have a right to expect thousands of American soldiers to risk their lives in conflicts fought for reasons of unadulterated altruism, but America can and should, given the existence of appropriate circumstances, provide them with the means with which they can wage their own struggles. 
This, it should be noted, is an application of the Reagan Doctrine to the post-Cold War world. The Reagan Doctrine had first been identified by Charles Krauthammer in an article he wrote for Time magazine in 1985. "The Reagan Doctrine," Krauthammer explained, "proclaims overt and unashamed American support for antiCommunist revolution" (Krauthammer, 1985). While the doctrine receives greater attention in the following chapter, the neoconservatives who spoke out on its behalf considered themselves to be speaking out on behalf of a doctrine requiring the arming of those who were revolting against unjust governments. "We need not stand in fear and trembling of helping others fight for their own freedom," Kirkpatrick had argued in the mid-1980s (Kirkpatrick, 1985/1988: 431).

It was a doctrine which once again betrayed the realist-neoconservative divide on what Stanley Hoffman called the 'state vs. human beings' dilemma of international politics (see Hoffman, 1981: 3). "If client rulers have the 'right' to ask for foreign assistance to maintain themselves in power," Kirkpatrick argued when referring to those communist regimes in the Third World which regularly turned to the Soviet Union for aid, "citizens deprived of their rights can ask for external aid to reclaim them" (Kirkpatrick, 1986/1988: 445). This was the core of the Reagan Doctrine, a doctrine said to support the "traditional American doctrine that armed revolt is justified as a last resort where rights of citizens are systematically violated" (Kirkpatrick \& Gerson, 1989: 20). It was a doctrine which many neoconservatives wished to see outlive the Cold War.

After the outbreak of ethnic violence in the Balkans, neoconservatives certainly wished to see the doctrine applied in Bosnia. The decision by the international community to impose an arms embargo on all the participants fighting in the former Yugoslavia educed the ire of many neoconservatives. "There are few outrages in recent international history," Richard Perle argues, "to compare to the United Nations arms embargo that, under the pretense of preventing a greater conflict, deprived Bosnian Muslims of the means of self-defense as the Serbs, who had guns, killed hundreds of thousands" (Perle, 2008: 17). Kirkpatrick agreed, claiming, "The arms embargo was the clearest example of a UN action that made the situation worse" (Kirkpatrick, 2007: 190). For neoconservatives, the national idea always imposes obligations on America. Even if it does not impose an immediate obligation to act militarily, it imposes an obligation to assist others to do for themselves that which America cannot. It is an obligation no less consequential. 
While neoconservative democratic realists are more willing than democratic globalists to specify what the national idea requires of America, the Reagan Doctrine is not free from moral ambiguity. The central point becomes one of control, that is, how does America control the minorities on whom it confers military aid? And to what ends will those embattled minorities employ such aid? Will they employ it in a way which satisfies America's idealistic sensibilities, or will it be employed to exact revenge against rival ethnic groups? After all, the contras were not the "freedom fighters" they were said to be. When referring to Reagan's use of such terms to describe the contras, even Robert Kagan acknowledged that

it was indisputable that contra troops in their attacks often made no distinction between civilians and armed Sandinista soldiers. It was the contras' policy, de facto if not always de jure to treat civilians who helped the Sandinistas as combatants (Kagan, 1996b: 356).

America should, of course, always be willing to offer aid to those eager and willing to fight for fundamental human rights, especially in situations approximating the one which prevailed in Bosnia. The idea and principle itself is one worthy of retention, even if it must be governed by prudence and with a degree of selectivity. A rhetorical commitment to the national idea is commendable, but one must always carefully consider what the idea requires of America. National resources are never infinite, and policy-makers should never be reckless with the lives of those men and women who have chosen to serve their country.

Neoconservatives are as willing as any school of foreign policy thought to speak about the big issues in world politics, regularly couching their policy recommendations in terms of the "national interest." However, it is the protection of the national idea which evokes their unwavering commitment. For neoconservatives, preserving this idea should be considered a vital national interest. It is not one they openly speak about, but it is one implicit in their foreign policy writings. All neoconservatives speak about the importance of the national idea and all emphasise the importance of adopting a foreign policy dedicated to promoting human rights. "Government, in the American view," Jeane Kirkpatrick argued, 
has no purpose greater than that of protecting and extending the rights of its citizens. For this reason, the definitive justification of government policy in the U.S. is to protect the rights - liberty, property, personal security of citizens. Defending these rights or extending them to other peoples is the only legitimate purpose of American foreign policy (Kirkpatrick, 1981: 42).

Defending the national idea and thwarting the emergence of subversive and totalitarian ideas are the tasks neoconservatives set themselves. And there is, they would argue, no more compelling American national interest than that.

\section{Conclusion}

This chapter has examined the neoconservative attempt to protect the national idea of America. This idea held that governments are instituted to secure the rights of the governed. Neoconservatives sought to protect this idea in a variety of ways; they have questioned those who have misconstrued the meaning of America's conception of human rights; they have written extensively to remind Americans of the historical relevance of the national idea; they have challenged the realist conception of the national interest; and they have emphasised the importance of discrediting those ideas embedded in rival universalisms such as fascism and communism which challenge the natural rights philosophy underlying the American regime.

These are, in short, the lengths to which neoconservatives have gone to protect the liberal democratic idea, an idea which had its roots in the Enlightenment and an idea shaped by a profound faith in certain moral truths about human nature and the basis of legitimate government. The attempt to protect the national idea is a distinguishing feature of the neoconservative approach to American foreign policy. It is a feature which must figure prominently in any attempt to define neoconservatism through the ideas and beliefs of its leading foreign policy intellectuals. Too often, I argued, scholars emphasise the undeniable importance of material interests while overlooking less concrete interests, including the survival of ideas. The neoconservative conception of the national interest is not a Straussian inspired project aiming to rescue America from the perils and degradations of modernity. It is a distinctly American project, itself very much shaped by modernity. 


\section{Chapter 4}

\section{The War of Ideology}

This chapter critically engages with what is often described as the neoconservative war of ideology. This is a core component of the neoconservative approach to American foreign policy, one often emphasised but rarely explored with the degree of rigour it deserves. The attempt to promote liberal democracy is, for many neoconservatives, intimately bound with the attempt to protect the national idea. It is, after all, only within a liberal democracy, it is often argued, that a citizen's civil and political liberties can be respected. Yet it is predominantly for ideological reasons, I argue, that neoconservatives endlessly emphasise the necessity of advancing liberal democratic principles around the world. There are, to be sure, instances when neoconservatives speak of the strategic reasons as to why America should undertake this task, but their ideological mindset makes them prone to recycle any argument which reinforces the need to promote liberal democracy. The influence ideology has had on neoconservatives cannot be understated, for they regularly speak of its impact on their personal lives. "I was raised," Joshua Muravchik explained, "in a home in which ideology was everything" (Muravchik, 2007).

Ideology itself, of course, is a term which defies simple generalisations. When Michael Hunt wrote Ideology and U.S. Foreign Policy (1987), he identified a number of attitudes in American society on liberty, race, and revolutions, which he believed constituted an American foreign policy ideology. Yet he also emphasised the difficulty of crafting a definition of ideology which would satisfy all political scientists. "Much like imperialism and liberalism, other protean concepts frequently bandied about in serious historical and political discourse, ideology is hard to pin down," he acknowledged (Hunt, 1987: xi).

When neoconservatives speak of ideology, they always speak of it in a combative and confrontational way. They do not clearly define what ideology is, but they leave their readers with no doubt that they believe that liberal democracy must be defended against all rival ideologies competing for the loyalties of mankind. They speak of ideology in rather simple dualities - liberal democracy vs. totalitarian communism, liberal democracy vs. Islamic fascism, liberal democracy vs. autocracy. While one can sympathise with those who insist that "ideology" itself is a term deserving of greater analytical thoroughness and conceptual clarity, this chapter engages with the 
neoconservative war of ideology on neoconservative terms, asking to what extent this ideological combativeness has led American foreign policy astray.

Neoconservatives wage their ideological struggles on behalf of liberal democracy in a variety of theatres, from the chambers of the United Nations to the corridors of power in Washington D.C. to the lion's den of the Middle East. Whether it was Daniel Patrick Moynihan's struggles at the United Nations against the growing number of Third World dictatorships which had recently won independence from European colonial powers, or Henry Jackson's attempt to lift restrictions on the number of people the Soviet Union permitted to emigrate, neoconservatives regularly betray their credentials as formidable and earnest ideologists.

After documenting these instances of ideological contestation, I argue that the neoconservative elevation of ideology above all else has led to two problematic policy recommendations, the first throughout the Cold War and the second throughout the war on terror. In the former instance, it left neoconservatives intellectually ill equipped to fully appreciate the role statesmanship can play in defusing international conflict. In the latter, it has led to an inexpiable failure to come to terms with the complexity of the contemporary wave of Islamic suicide terrorism. While in the last chapter I argued that the neoconservative attempt to protect the national idea was a worthy rhetorical undertaking, even if some neoconservatives were not entirely clear about what the national idea required of America; this chapter strongly questions the desirability of placing such a strong emphasis on ideology in international affairs. In fact, I argue that the ideological mindset of neoconservatives precluded them from even contemplating that Cold War tensions could be reduced, just as it encouraged them to call for the ideological transformation of the Middle East. It has, in short, led to policy recommendations mired in ideology and devoid of prudence. When it came to the Cold War, Ronald Reagan fortunately turned away from such recommendations. When it came to the war on terror, George W. Bush did not. That, at least in part, is why America went to war in Iraq.

\section{$\underline{\text { The War of Ideology goes to the United Nations }}$}

Long before America entered Baghdad, Daniel Patrick Moynihan had taken the neoconservative war of ideology to the United Nations. He secured his ambassadorship to the United Nations in $1975-76$ by railing against the "anti- 
Americanism" said to have been permeating the chambers of the General Assembly and Security Council, not to mention the organisation's multifarious agencies and commissions. He accepted his diplomatic post harbouring one fundamental assumption: "Democratic regimes and values," he believed, "were under totalitarian assault in every region of the world, and resistance was everywhere weakening" (Moynihan, 1977: 20). The United Nations, according to Moynihan, was a forum being used by many Third World states, recently granted their independence throughout the heady days of decolonisation following World War II, to launch an all out ideological assault on America and liberal democratic principles. "We are a minority. We are outvoted," he observed in "The United States in Opposition" (1975), the article for Commentary which captured the attention of the Ford administration and secured him his ambassadorship. This, however, he reassured his readers, was "neither an unprecedented nor an intolerable situation. The only question is what do we make of it" (Moynihan, 1975: 41).

Moynihan had little doubt as to what America should make of its position at the United Nations. First, it needed to be cognizant of the source of the ideas shaping Third World criticisms of America, criticisms indicting America for the degraded state of the environment, the world's food shortage, and the general economic malaise experienced by the nations of the Third World. Moynihan argued that it was socialist doctrine, transferred from Europe and implanted in the soil of European colonial possessions, which enabled the Third World's anti-capitalist and anti-American worldview to sprout. "They are learned ideas," he argued, "and they were learned by the new nations mostly where they mostly originated, in the intellectual and political circles of Britain of the late $19^{\text {th }}$ and early $20^{\text {th }}$ century" (Moynihan, 1975: 34). Moynihan's appraisal of the origins of the hostility America encountered at the United Nations once again demonstrates the importance neoconservatives assign to ideas in international politics. This time, however, the ideas giving rise to the exaggerated criticisms levelled by Third World states at America were said to emanate from the socialist left in Europe:

At root, the ideas of exploitation and discrimination represent a transfer to colonial populations of the fundamental socialist assertions with respect to the condition of the European working class, just as the idea of independence parallels 
the demand that the working class break out of bondage and rise to power (Moynihan, 1975: 34).

As a result of the Third World's hostility towards America, Moynihan recommended that America accept its position as a victimised minority at the United Nations and go into opposition. "Going into opposition," he argued, "requires first of all that we recognize there is a distinctive ideology at work in the Third World, and that it has a distinctive history and logic" (Moynihan, 1975: 41). This ideology, according to Moynihan, needed to be combated by American officials who were willing to accept America's faults, spotlight the far more serious faults of others, and refrain from engaging in the national self-flagellation hoped for and relished by other members of the international community. "It is past time we ceased to apologize for an imperfect democracy. Find its equal," Moynihan challenged (Moynihan 1975: 43). Concluding his 1975 article, he identified the one point of ideological counterattack which he knew would instinctively appeal to Americans:

Cataloguing the economic failings of other countries is something to be done out of necessity, not choice. But speaking for political and civil liberty, and doing so in detail and in concrete particulars, is something that can surely be undertaken by Americans with enthusiasm and zeal (Moynihan, 1975: 42).

Indeed, this was the task Moynihan set himself at the United Nations. It was time, he argued, "that the American spokesman came to be feared in international forums for the truths he might tell" (Moynihan, 1975: 42). They would be truths aiming to debunk the "myths" propagated by members of the international community who criticised America for a litany of human rights abuses all the while perpetrating their far more egregious denials of civil and political liberties in their home countries. "More and more," Moynihan complained, "the United Nations seems only to know of violations of human rights in countries where it is still possible to protest such violations" (Moynihan, 1977: 20). The charges against America were said to be as diverse as they were erroneous. "The charge could range from genocide to unemployment," he argued, "but it always followed the Orwellian principle: hit the democracies in the one area where they have the strongest case to make against the dictatorships" (Moynihan, 1977: 21). 
Moynihan's influence on the neoconservatives who came after him cannot be understated. Following in his path, Joshua Muravchik is one of today's sharpest neoconservative critics of the United Nations, spotlighting the organisation's failures in the field of humanitarian intervention, its inefficiencies and lack of financial accountability, and its preoccupation with censuring Israel for "crimes" it may or may not have committed. ${ }^{89}$ Even if the United Nations "proved unable to muster the military strength to become the bulwark of world order that its founders had envisioned," Muravchik argues, "the UN could have stood as an inspiration, a beacon of right and wrong in the behaviour of states. It has, alas, been nothing of the sort" (Muravchik, 2004: 38). For Muravchik, nothing revealed the "moral bankruptcy" of the United Nations more than the now defunct Human Rights Commission, a commission invested with the responsibility for reporting on alleged human rights abuses in the world. As Muravchik puts it in The Future of the United Nations: Understanding the Past to Chart a Way Forward (2005),

Nowhere is the UN's broken moral compass more vividly on display than in the UN Commission on Human Rights. Year after year, many of the governments on the short list cited annually by Freedom House as the 'worst of the worst' human rights violators (those receiving the poorest possible freedom score of 7 or 6.5 on its scale of 1 to 7) secure seats on the commission (Muravchik, 2005: 59).

As a result of the commission's composition, its reports were said to elide the deeds of the world's worst human rights violators. "When the time comes to examine specific cases," Muravchik explains, "rarely is a word of criticism aimed at the most brutal tyrannies, no matter how flagrantly they may traduce the most elementary of rights" (Muravchik, 2005: 60).

For neoconservatives, the contest with the United Nations is, and always has been, a war of ideology. In fact, their quest to de-legitimise the United Nations is just as much an attempt to re-legitimise America and its liberal democratic principles, reinvigorating the national faith in the uniqueness of the American regime. If the United Nations is morally bankrupt, as neoconservatives are inclined to argue, then America, so the reasoning runs, stands alone as the sole force for good in the world.

\footnotetext{
${ }^{89}$ For an introduction to Muravchik's critiques of the United Nations, see Muravchik, 2002; 2004; and 2005.
} 
"It is exceedingly strange," argued William Kristol and Lawrence Kaplan, "to view the United Nations as a higher moral authority than the United States" (Kaplan \& Kristol, 2003: 91). It is strange, they add, because "The U.N., after all, is simply a collection of sovereign states. The organization makes no distinction based on political systems; a tyranny is as welcome as a democracy" (Kaplan \& Kristol, 2003: 91). Whether neoconservatives overstate their case against the United Nations is a question I examine in the concluding chapter. Suffice to note, however, that in the neoconservative presentation, the United Nations is a forum where dictators run amok and mendacity reigns, a forum where the behaviour of democracies is endlessly assailed, and the behaviour of tyrants is inexplicably excused.

\section{The Jackson-Vanik Amendment and the Soviet Empire}

If Daniel Patrick Moynihan made his stand on behalf of liberal democratic principles at the United Nations, Henry Jackson made his stand on the floor of the United States Senate. Serving the state of Washington since 1940, Jackson, a Senate Democrat, became one of the leading critics of the Nixon-Kissinger conception of détente. ${ }^{90}$ His attempt to attach the Jackson-Vanik amendment to a trade bill in 1974, a bill crafted by the Nixon-Kissinger administration, has received considerable attention in a large amount of biographical literature. ${ }^{91}$ The amendment, in short, was an attempt to make Soviet access to Western goods contingent upon the Soviet Union's willingness to liberalise its restrictive emigration policies and increase the number of exit visas it granted, especially but not exclusively for Soviet Jews. It was, in other words, an attempt to influence the internal affairs of the Soviet Union. As Jackson put it,

We must be willing to use our human rights concerns in the bargaining process with other nations. Nations seek our grain, our arms, our technology. Why should we not seek greater protection for internationally recognised human rights?

\footnotetext{
${ }^{90}$ I spend more time on Jackson's critiques of the Nixon-Kissinger conception of détente in the following chapter. It was he more than any other, I believe, who paved the way for the neoconservative unipolarists of the 1990s.

${ }^{91}$ There is no consensus in this literature as to whether Jackson's amendment advanced the cause of human rights or stiffened Soviet intransigence. For a presentation more sympathetic to Kissinger, see Isaacson, 2005: 611-621. For presentations more sympathetic to Jackson, see Horner, 1997: 109-129; and Kaufman, 2000: 268-283. For a concisely written account, see Greene, 1995: 122-123. For a running commentary on the amendment, which is part of a much larger study on détente, see Garthoff, 1994.
} 
That is the essence of our effort in Congress to place America's economic power behind the right to emigrate (Jackson, 1977/1990: 203).

It was an attempt, however, very much at odds with the Nixon-Kissinger administration's belief that nations should be judged more by their external conduct than their internal practices. The Nixon-Kissinger administration had not wanted to make the internal practices of the Soviet Union the criterion upon which the administration's foreign policy would be based. Demanding that the Soviet Union make such a concession, Kissinger complained, was a misguided attempt to link the promise of greater trade with the need for internal reform. ${ }^{92}$ Walter Isaacson, Henry Kissinger's biographer, argues, “The idea of making such a demand on another sovereign nation was beyond Kissinger's ken" (Isaacson, 2005: 613). The demand, in fact, created the stage for a significant executive-legislative struggle, one which Jackson would eventually win when the amendment was attached and the bill was passed in 1974, albeit one which came at a high cost when the Soviets simply withdrew from the deal and imposed even tighter restrictions on Jewish emigration. ${ }^{93}$

What is more important than a standard recounting of events, however, is an understanding of why Jackson and his neoconservative supporters saw the right to emigrate as a fundamental human right, one which governments should not abridge. Jackson claimed that both he and the Congress embraced the amendment because the right to emigrate was "the touchstone to all human rights" (Jackson, 1977/1990: 203). If the Soviet Union respected a person's right to emigrate, so the reasoning ran, then Soviet leaders would be compelled to act more cautiously in the field of human rights in general. Jeane Kirkpatrick explains the logic as well as anyone. At the World Conference on Soviet Jewry in Jerusalem in 1983, she explained, "the right to emigrate is a necessary guarantee for other rights since it ensures a citizen the ability to emigrate from a country where these other rights are denied" (Kirkpatrick, 1983/1988: 57).

\footnotetext{
${ }^{92}$ As Kissinger put it, "Nixon had sought to encourage moderation in Soviet international conduct by making restraint in Soviet foreign policy the litmus test of increased trade with America. His opponents took linkage a step further by seeking to use trade as a means of producing the domestic upheaval in the Soviet Union, and at a time when the Soviet Union was still strong and confident" (Kissinger, 1994: 755).

${ }^{93}$ John Lewis Gaddis argues, "the Jackson amendment failed, in the end, to serve either the cause of détente, or trade, or human rights.” For his concisely written critique, see Gaddis, 2005: 312-313.
} 
To this day Jackson's attempt to raise the issue of human rights in America's dealings with the Soviet Union finds support among Soviet dissidents. Natan Sharansky, a Jackson admirer who spent nine years in a Soviet prison, argues, "We refuseniks knew that the Soviets had no intention of allowing masses of Jews to leave, and we saw the amendment as putting our plight on the international agenda" (Sharansky, 2004: 120). He, like Kirkpatrick, explained why the Soviets were reluctant to confer such a right: "Freedom of emigration was a lethal threat: The regime understood that when an escape is an option, the fear that was used to stabilize its rule would not be nearly as effective" (Sharansky, 2004: 118).

The Jackson-Vanik amendment, however, was more than an attempt to raise the issue of human rights in America's dealings with the Soviet Union; it was an ideological assault on the very nature of the Soviet regime, a regime not resting on the consent of the governed and one which Jackson, through a persistent advocacy of human rights concerns, wished to change:

I believe that we ought to press our traditional commitment to human rights in the emerging détente not only because this commitment is a most solemn pledge, not only because these values are right in themselves, but because it must be a purpose of détente to bring the Soviet Union into the community of civilised nations (Jackson, 1973/1990: 190).

The cause of human rights, according to neoconservatives, could not be de-linked from political systems and therefore could not be de-linked from the wider ideological struggle against communism. As Muravchik put it,

Two political systems today offer themselves as models - democracy and Communism. Most of the world has already adopted or come to live under one model or the other, while that which remains is constantly pulled between the two. One of these models is predicated on belief in human rights; the other is predicated on their denial. To conduct a human rights policy that is oblivious to the contest between these two models is to ignore the central human rights question of our time (Muravchik, 1986: 235). 
The ideas behind the Jackson-Vanik amendment, in other words, aimed to challenge the very nature of the Soviet regime. It was an ideological challenge Kissinger himself noted. "To Jackson and his supporters," he explained, "the issue of Jewish emigration was a surrogate for the ideological confrontation with communism" (Kissinger, 1994: 754). This was no secret, for neoconservatives were quite candid about their support for an ideologized human rights policy. As Muravchik argued, "a human rights policy is profoundly ideological, and should be unabashedly so" (Muravchik, 1986: 234).

Yet the re-ideologization of American foreign policy would be elevated to a new height when Jeane Kirkpatrick wrote "Dictatorships and Double Standards." Originally published in Commentary in 1979, it is an article reprinted in its entirety in Dictatorships and Double Standards: Rationalism and Reason in Politics (1982), a book in which Kirkpatrick included several of her more noteworthy writings on American foreign policy. One author described the article as "a turning point text similar to George Kennan's 'X' essay articulating the case for containment”' (Diggins, 2007: 214). The article certainly caught the eye of Ronald Reagan, securing Kirkpatrick her ambassadorship to the United Nations. Yet it was the implication of this article, I explain below, which is the clearest indication that neoconservatives could not envision a world in which ideology could be transcended. By suggesting that the Soviet Union was impervious to internal reform, and that communist regimes would remain a fixture of the international system, neoconservatives revealed their unwavering conviction that ideology, quite literally, ruled the world and dictated the behaviour of nations.

\section{The Kirkpatrick Thesis}

In "Dictatorships and Double Standards," Jeane Kirkpatrick argued that by insisting that the autocratic regimes in Iran and Nicaragua abruptly liberalise and democratise in the late 1970s, the Carter administration became complicit in "the replacement of moderate autocrats friendly to American interests with less friendly autocrats of extremist persuasion" (Kirkpatrick, 1979/1982: 23). Drawing attention to the administration's decision to withdraw support from the Shah of Iran and President Somoza's authoritarian regime in Nicaragua, she argued that 
In each of these countries, the American effort to impose liberalization and democratization on a government confronted with violent internal opposition not only failed, but actually assisted the coming to power of new regimes in which ordinary people enjoy fewer freedoms and less personal security than under the previous autocracy - regimes, moreover, hostile to American interests and policies (Kirkpatrick, 1979/1982: 26).

In order to prevent religious fundamentalists such as Ayatollah Khomeini and Marxist revolutionaries such as the Sandinistas coming to power, Kirkpatrick argued that America should extend its support to autocratic regimes serving American interests and guerrilla forces attempting to roll back communist gains in the Third World. In order to justify such support, Kirkpatrick revived the idea of totalitarianism, distinguishing between the totalitarian Marxist governments on the left and the authoritarian governments friendly to American interests on the right, the latter of which were said to be more amenable to incremental liberalisation and democratisation:

Since many traditional autocracies permit limited contestation and participation, it is not impossible that U.S. policy could effectively encourage this process of liberalization and democratization, provided that the effort is not made at a time when the incumbent government is fighting for its life against violent adversaries, and that proposed reforms are aimed at producing gradual change rather than perfect democracy overnight (Kirkpatrick, 1979/1982: 51).

If, however, Kirkpatrick considered authoritarian regimes of the right to be more amenable to incremental liberalisation and democratisation, she foresaw little likelihood of totalitarian communist regimes transforming themselves into anything other than - totalitarian communist regimes. ${ }^{94}$ The "history of this century provides no grounds for expecting that radical totalitarian regimes will transform themselves," she argued (Kirkpatrick, 1979/1982: 51). This has been described by one observer as the "doctrine of irreversibility," a doctrine predicated upon the belief that "once a

\footnotetext{
${ }^{94}$ For an excellent analysis and critique of Kirkpatrick's views on totalitarianism, which is part of a much larger study on how Western intellectuals came to think of totalitarianism, see Gleason, 1995 198-210).
} 
communist system takes hold, there is no turning back and no way out, no possibility of change or reform" (Diggins, 2008: 217).

Kirkpatrick was not the only neoconservative to emphasise the importance of recognising the distinction between authoritarian and totalitarian regimes. "They," Moynihan explained prior to the publication of Kirkpatrick's article and while referring to the authoritarian regimes of the right, "commit abominations in practice; the Communist countries commit abominations on principle" (Moynihan, 1977: 24). There was something qualitatively different, in other words, about regimes committed to an ideological creed denying the existence of human rights to those "merely" persecuting and harassing dissidents who challenged an autocratic government's authority. "Even authoritarian states at their worst," argued Norman Podhoretz, "generally allow more freedom - economic, cultural, religious - than the mildest of Communist states" (Podhoretz, 1981: 42).

If there were fewer political prisoners in the Soviet Union and Eastern Europe in the 1980s than there were throughout the Stalinist era, this in no way, according to Walter Laqueur, a frequent contributor to Commentary throughout this period, should have been interpreted as evidence of the failure of the totalitarian enterprise. In fact, one could argue, Laqueur claimed,

that if there has been a certain relaxation of domestic pressure in the Eastern bloc, this is a consequence of the triumph rather than the failure of totalitarianism; the opposition has been crushed, large parts of the population have been successfully indoctrinated, and in these circumstances there is no need for more drastic measures such as mass purges and executions (Laqueur, 1985: 32).

The practical implications of the Kirkpatrick thesis sparked an impassioned debate. From the Salvadoran junta to the contras of Nicaragua, the decision to align America with international actors of questionable moral repute was one of the more controversial decisions made by an administration since Vietnam. As such, critiques of Kirkpatrick's thesis abound. Tony Smith, one of the leading scholars on America's attempts to promote democracy abroad, has argued that the "greatest flaw in Kirkpatrick's argument was its failure to specify how one correctly evaluates the prospects for democracy in a given country" (Smith, 1994: 289). When addressing her faith in the permanence of communist regimes, Smith added, "She simply 
assumed democracy could not materialize, so that realistically Washington's range of choices was limited to helping authoritarian partners or allowing their totalitarian opponents to win" (Smith, 1994: 289).

Others, in a similar spirit, drew attention to the difficulties America had in moderating some of the excesses of the El Salvadoran government, itself fighting a communist insurgency, and the Nicaraguan contras. "Maintaining even tenuous control over allies such as the Salvadoran armed forces or the Nicaraguan contras," notes William LeoGrande in Our Own Backyard: the United States in Central America, 1977-1992 (1998), "proved as difficult for Washington as plotting strategy against the Salvadoran guerrillas and the Sandinistas" (LeoGrande, 1998: ix). While referring to Kirkpatrick's distinction between totalitarianism and traditional authoritarianism, Anatol Lieven cynically and sharply concludes, "this distinction had been nothing more than a cheap debating trick, intended to demonstrate that Washington's Latin American scum were better than Moscow's Eastern European scum" (Lieven, 2004: 76).

Debating trick or not, it was a distinction enabling the re-ideologization of American foreign policy. Throughout the Cold War, neoconservatives never wavered from the view that the Soviet Union was an implacable totalitarian adversary committed to global expansion. It was not, in short, a state resembling any other except perhaps Hitler's Germany. Accepting Kirkpatrick's distinction, Norman Podhoretz, along with many other foreign policy writers for Commentary, unrelentingly framed the Cold War in ideological terms. The Soviet Union, Podhoretz thundered, “is a revolutionary state, exactly as Hitler's was, in the sense that it wishes to create a new international order in which it would be the dominant power" (Podhoretz, 1980a: 39). ${ }^{95}$ There was always an ever-present suspicion among neoconservatives that the revolutionary nature of the Soviet regime would cause America a world of trouble. "Rulers who use force to subdue opponents, conquer neighbours, and intimidate allies can hardly be expected to treat the rest of us differently," Kirkpatrick concluded (Kirkpatrick, 1987/1990: 38).

Yet, as neoconservatives would be the first to argue, ideas have consequences. The idea that the Soviet Union remained an irredeemable totalitarian superpower,

\footnotetext{
${ }^{95}$ For a review of Podhoretz's articles written for Commentary in which he emphasises the threat posed by the Soviet Union's ideological messianism, see Podhoretz, 1976; 1980a; 1980b; 1981; 1982; 1983. These are the articles to which I will frequently return over the course of this chapter and the next when I examine neoconservative critiques of détente.
} 
always alert to the possibilities of exploiting the West, is no exception to the rule. This image of the Soviet Union, in fact, tells us as much about the neoconservative mindset as it does about the nature of the Soviet Union in the 1970s and 1980s. Nations subscribing to an opposing ideology, according to neoconservatives, are untrustworthy nations. Power and ideology are presented as the key drivers of a country's foreign policy. The role of the statesman was seldom considered to be of importance in America's relations with the Soviet Union. "Personal affinities matter only at the margins of modern international relations," Kirkpatrick argued (Kirkpatrick, 1990b: 102). Americans themselves were often accused of succumbing to a certain inextirpable naiveté when they dared to contemplate that Cold War tensions could be reduced. "Americans have always been reluctant to admit that certain conflicts are fundamental and irreconcilable," noted Walter Laqueur (Laqueur, 1983: 13). Such arguments aimed to deflate expectations, obliterating whatever mirage may have existed in the minds of American policy-makers of an illusory future in which Soviet and American leaders cooperated and reconciled the interests of their nations.

The end of the Cold War, however, was a product of prudent and thoughtful statesmanship. Ronald Reagan, to be sure, embraced segments of the Kirkpatrick thesis; he undoubtedly supported those loosely defined "freedom fighters" in the Third World, instructing subordinates to do what was necessary to keep the Nicaraguan contras together "body and soul" (see Pemberton, 1998: 173). ${ }^{96}$ What Reagan did not appreciate, though, was that the ideological politics relished by neoconservatives precluded the possibility of statesmanship, the creative and visionary kind of which he and Gorbachev would display to end the Cold War. For neoconservatives such as Kirkpatrick, "The point" was said to be

clear and intractable: neither understanding among rulers nor contracts between governments eliminate power and its uses as a factor in relations among nations. We are stuck with power and politics and the permanent need to protect our interests and values. We cannot refashion relations among nations to fit utopian

\footnotetext{
${ }^{96}$ For a good overview of the Reagan administration's involvement in the Third World, see Westad, 2004: Ch. 11. For an overview of this involvement which is part of a much larger study on both America's and the Soviet Union's involvement on the periphery throughout the Cold War, see Westad, 2007: Ch. 9.
} 
models. We can only operate more or less skilfully and successfully in the world as it is (Kirkpatrick, 1990b: 103).

Reagan undoubtedly approved of Kirkpatrick's article in 1979, but it was he more than any other who transcended the ideological militancy of neoconservative cold warriors. It was Ronald Reagan, in short, who managed to operate in the world as it was, emancipating American foreign policy from the grip of those who elevated ideology over statesmanship, power over prudence, and the permanence of conflict over the possibility of its resolution.

\section{$\underline{\text { Reagan, Gorbachev, and the End of the Cold War }}$}

Commenting on early perceptions of the Reagan administration, John Lewis Gaddis, arguably America's most accomplished Cold War historian, argued, "rarely has there been a greater gap between the expectations held for an administration at the beginning of its term and the results it actually produced" (Gaddis, 1992: 119). When Reagan is spoken about in contemporary historical studies, to say nothing of the way in which he is discussed within the halls of academe, one is more than likely to hear of his ideological militancy, his arms build up, and his support for morally unsavoury regimes and guerrilla forces in the Third World. "Ronald Reagan," concluded one previously cited critic of the Reagan administration's involvement in Latin America, "was the premier hard-liner" (LeoGrande, 1998: 581). According to this presentation, Ronald Reagan was an ideologue. It is not only Reagan's detractors who emphasise his ideological mindset, however, for it is often celebrated among supporters who praise him for renewing the ideological challenge to Soviet communism. Paul Kengor's The Crusader: Ronald Reagan and the fall of Communism (2007) is one of the more recent attempts to depict Reagan as a perfervid anti-communist dedicated to toppling the Soviet empire.

Yet Ronald Reagan was a complicated figure, someone harbouring leadership quirks and a strategic vision which would go a long way towards enhancing the amount of trust between America and the Soviet Union. Only recently has a growing amount of critical yet respectful literature emerged on America's $40^{\text {th }}$ President, 
literature which has burnished Reagan's reputation and legacy. ${ }^{97}$ Reagan undoubtedly believed in an arms-build up, enabling America to negotiate with the Soviet Union from a position of strength, but he never viewed the Soviet Union in the apocalyptic terms that neoconservatives did, not even when he was calling the Soviet Union an “evil empire." This is one of the central arguments of John Patrick Diggins' Ronald Reagan: Fate, Freedom, and the Making of History (See Diggins, 2007: Ch. 6 \& 10). In fact, the speech Reagan delivered before the National Association of Evangelicals in 1983, the speech in which he employed such rhetoric, was aiming to shore up support among the evangelical right in the United States. Reagan had also edited the speech, excising a passage which suggested that the Soviet Union would "forever" remain an "evil empire" (see Diggins, 2007: 29).

Unlike many neoconservatives, Reagan rejected the idea that communism would remain a permanent fixture of the international system, famously declaring that the allure of the democratic way of life would "leave Marxism-Leninism on the ash heap of history as it has left other totalitarian ideologies which stifle the freedom and muzzle the self-expression of its citizens" (cited in Kengor, 2007: 140). This, Diggins argues, exposes a lack of cohesion between the ideas of Ronald Reagan and the ideas of those neoconservatives such as Jeane Kirkpatrick surrounding him throughout his first term. "Reagan, a political leader who believed that communism could not last," Diggins explains, "appointed as ambassador to the United Nations a scholar who believed it could" (Diggins, 2007: 217).

Yet Reagan was not prepared to wait on some uncontrollable chain of events to encourage reform within the Soviet Union; he genuinely believed he could, through the employment of a variety of means, expedite the collapse of the Soviet empire. By the end of Reagan's second year in office, according to Paul Lettow, the administration had issued a number of "formal directives" making it clear that the administration's goal was to exacerbate internal pressures within the Soviet Union by, inter alia, escalating the arms race (Lettow, 2006: 79).

Of course, to ask to what extent Reagan's policies contributed to Gorbachev's internal difficulties and willingness to improve relations with America is to ask one of

\footnotetext{
${ }^{97}$ For an intellectual biography on Reagan which challenges some of the conventional wisdom on the man, his worldview, and his presidency, see Diggins, 2007. For an excellent analysis of Reagan's antinuclearism, see Lettow, 2006. For a very shrewd and scholarly appraisal of Reagan's role in ending the Cold War, see Gaddis, 1992: Ch. 7; and 2005: Ch. 11. For an analysis which holds that Gorbachev was more instrumental than Reagan in ending the Cold War, yet still manages to speak of Reagan in quite a respectful and detached manner, see Leffler, 2007: Ch. V.
} 
the more provocative questions debated since the end of the Cold War. It seems reasonable to conclude, though, that Reagan's policies reinforced Gorbachev's preexisting penchant to find some accommodation with America, enabling him to divert resources away from the Soviet defence industry and towards the country's distraught economy. Even Archie Brown, Gorbachev's sympathetic biographer, concedes that there "is something in the argument, provided it is not overstated, that saw the American willingness to outspend the Soviet Union in the search of new weapons systems as one of the stimuli to Gorbachev's policy innovations" (Brown, 1997: 230). It was certainly Gorbachev's greatest hope that he could reform and revitalise the Soviet Union, knowing, in the words of Melvyn Leffler, that "the primary threat emanated from within, from the communist system's failure to fulfil the expectations of the Soviet people, to produce the goods people wanted, and to ensure the way of life they anticipated" (Leffler, 2007: 376).

That the Soviet economy was in a state of stagnation in the 1980s cannot be doubted. "Defense," argues Stephen Brooks and William Wohlforth, "claimed a massive proportion of Soviet resources. Despite massive measurement problems," they explain, defence was widely considered to be consuming "40 percent of the Soviet state budget and 15-20 percent of GDP (gross domestic product) in the early 1980s, or at least four times the U.S. level" (Brooks \& Wohlforth, 2004: 88-89). The Reagan administration's goal, therefore, was “to weaken the Soviet system itself in order to encourage change within it" (Lettow, 2006: 79). Reagan may have been fortunate to enter office at such a time of great decay within the Soviet Union, according to Gaddis, but "it took more than luck to recognise what was happening, and to capitalize on it to the extent the Reagan administration did" (Gaddis, 1992: 123). The structural difficulties within the Soviet Union should not, of course, diminish Gorbachev's role in ending the Cold War. ${ }^{98}$ From the often emphasised "new thinking" of Gorbachev and the advisers he surrounded himself with to the renunciation of the Brezhnev Doctrine, scholars advance a number of persuasive ideational explanations for the end of the Cold War. ${ }^{99}$

\footnotetext{
${ }^{98}$ The two scholars who argue that material factors, and the internal decay of the Soviet Union, contributed mightily to the end of the Cold War and essentially forced Gorbachev's hand are William Wohlforth and Stephen Brooks. For an introduction to their writings on this topic, see Brooks \& Wohlforth, 2004: Ch. 4.

${ }^{99}$ For some of the best accounts of the origins of the "new thinking" permeating throughout the Kremlin in the Gorbachev era, see Brown, 1996; English, 1999 \& 2002; and Levesque, 2004a: Ch. 7. For a good overview of Gorbachev's decision to withdraw from various regional conflicts and accept
} 
Many of the decisions made throughout this period, however, were made within a context of growing inter-state trust between America and the Soviet Union.

The idea that summitry and national leaders could move history in a direction culminating in an end to the Cold War was strongly questioned, if not categorically rejected, by neoconservatives writing throughout this period. If they supported Reagan's arms build up, itself not an entirely unreasonable position, they had little faith in Reagan's capacity to use that arms build up as a means to seek better relations with the Soviet Union. When Kirkpatrick wrote about the Geneva summit in 1985, she lambasted Americans for investing their "quixotic" hopes in the role statesmen could play in the affairs of nations:

Our near obsession with the Reagan-Gorbachev conversations reflects, I think, a highly personalized and deeply flawed conception of international politics in which clashing civilizations and great states are seen to be embodied in two leaders - much as two men stand for the forces of law or lawlessness, good and evil, in traditional Western movies (Kirkpatrick, 1985/1990: 107).

Again, Kirkpatrick was not alone in this assessment. Richard Pipes complained that Reagan was beginning to shift arms control negotiations "from the periphery of his foreign policy, where they properly belong, to its very center" (Pipes, 1984: 18). Podhoretz also proved to be just as disillusioned as Kirkpatrick and Pipes with what he described in the pages of Foreign Affairs as "The Reagan Road to Détente" (1985). Perhaps "lured by seductive fantasies of what historians in the future might say of him as a peacemaker," Podhoretz regretfully concluded, "Mr. Reagan seems ready to embrace the course of détente wholeheartedly as his own" (Podhoretz, 1985: 463). What really aroused Podhoretz's ire, however, was that Reagan was not ideological enough, at least not after he became President. "Mr Reagan, while perhaps more swayed by ideological conviction than most professional politicians, showed in his first term," Podhoretz lamented, "that for better or worse he was more politician than ideologue" (Podhoretz, 1985: 461).

Ronald Reagan, to the never ending frustration of neoconservatives, submerged his unquestionable contempt for communism beneath an optimistic faith in the power 
of personalities to resolve national differences. "What was unique about Reagan," Leffler argues, "was his confidence in himself and his capacity to effectuate change" (Leffler, 2007: 341). Reagan's much discussed anti-nuclearism and his vision of a world devoid of nuclear weapons contributed significantly towards effectuating the change in U.S.-Soviet relations to which Leffler refers. Paul Lettow's Ronald Reagan and his Quest to Abolish Nuclear Weapons (2006) is the most comprehensive account of the evolution of Reagan's anti-nuclearism. From his days as a Truman Democrat to his articulation in 1983 of the Strategic Defense Initiative (SDI), a space based missile defence system Reagan hoped would render nuclear weapons obsolete, Ronald Reagan crusaded for the abolition of nuclear weapons. The incorporation of this vision into key strategic directives and in Reagan's dealings with Gorbachev, according to Lettow, "constituted a significant change in U.S. policy" (Lettow, 2006: 198). It was a vision which would have been dismissed as naïve and unworkable by preceding administrations just as it was dismissed as naïve and unworkable by some of Reagan's closest advisers. ${ }^{100}$

Yet to what extent, one can fairly ask, did this anti-nuclearism enhance the amount of trust between Reagan and Gorbachev? After all, was it not Reagan's stubborn insistence on maintaining SDI at all costs, especially at Geneva in 1985 and Reykjavik in 1986, which threatened to tear U.S.-Soviet relations asunder? Did Gorbachev not regularly express his concern throughout these summits that America was developing a missile defence system enabling them to launch a nuclear first strike against the Soviet Union without fear of retaliation? Reagan certainly was stubborn in his quest to maintain SDI, and Gorbachev certainly expressed his concern about the strategic advantages which would accrue to the United States if it was successful in developing SDI. However, neither Reagan's obdurateness nor Gorbachev's fears ruptured U.S.-Soviet relations. As Gorbachev put in his memoirs while referring to the first summit at Geneva in 1985,

Tempers became heated whenever we touched upon topics such as human rights, regional conflicts and the notorious Strategic Defense Initiative (SDI).

Nonetheless, I realized by the end of our two day-meeting that Ronald Reagan too was a man 'you could do business with' (Gorbachev, 1996: 405).

\footnotetext{
${ }^{100}$ Richard Perle, for instance, was brought in by then-Defense Secretary Frank Carlucci in 1987 to specifically dissuade Reagan "of his nuclear abolitionism.” See, Lettow, 2005: 234-235.
} 
Gorbachev, in fact, was every bit as committed to the abolition of nuclear weapons as was Ronald Reagan. Both leaders, according to Archie Brown, were driven by a "desire to achieve the total elimination of nuclear weapons" (Brown, 1996: 230-231). To the chagrin of their advisers, they had even come close in 1986 to concluding an agreement abolishing all nuclear weapons at Reykjavik, Iceland, only to see the summit end in disappointment and frustration after Reagan refused to confine SDI research to scientific laboratories. Yet even after Reykjavik, ${ }^{101}$ a summit in which, according to one historian, both leaders "let their antinuclear radicalism take hold," relations did not deteriorate (Reynolds, 2007: 392). "Indeed," Brown notes, "Gorbachev trusted Reagan more from that time onwards, and the way he spoke about him in private to close colleagues was much more respectful after Reykjavik than before" (Brown, 1996: 233). This mutual respect led to some of the most significant disarmament agreements in the history of U.S.-Soviet relations. In 1987, for instance, America and the Soviet Union, under the stewardship of these two men, would go on to conclude the Intermediate Nuclear Forces Treaty, a treaty abolishing a whole category of nuclear weapons. ${ }^{102}$

Such agreements were only made possible by the affection these two men had for each other and their shared vision of a world freed from the spectre of nuclear holocaust. In their thoughtful writings on leadership and the end of the Cold War, Greg Breslauer and Richard Lebow ask,

Was there something about the personal rapport between these two leaders that encouraged conciliation and helped them to sustain the momentum of that process once it had begun? We think the answer is 'yes.' Gorbachev shared Reagan's horror of nuclear weapons. The fact that both men happened to share a vision of a world without nuclear weapons was salutary to the process of mutual conciliation. That they were in power at the same time was a remarkable and perhaps even necessary coincidence (Breslauer \& Lebow, 2004: 183).

The role that statesmanship can play in defusing international conflict continues to be dismissed by neoconservatives, even after the Cold War. The dismissal is a result

\footnotetext{
${ }^{101}$ For a good overview of what happened at Reykjavik, see Oberdorfer, 1998: 189-209.

${ }^{102}$ For a good analysis of the arms control agreements reached throughout this period, and their contribution to the end of the Cold War, see Evangelista, 2004: Ch. 4.
} 
of an ideological mindset which sees conflict as endemic within the international system, conflict made inevitable by the presence of states with opposing ideologies and immoderate ambitions. When neoconservatives write about the end of the Cold War, they advance a number of explanations for its unexpected termination. For Krauthammer, it was Ronald Reagan's arms build up which "brought the Soviet Empire to its knees" (Krauthammer, 2008). For Richard Pipes, it was Ronald Reagan's militant anticommunism that convinced the Politburo to choose "a man committed to perestroika and disarmament" (Pipes, 1995: 158). For Joshua Muravchik, America won the Cold War "by virtue of the democratic ideas on which the American system is based and on the failure of the Communist idea" (Muravchik, 1991: 1). Whatever the merits of these arguments, one thing is clear: regardless of whether it is in their present commentary or in their immediate reflections following the end of the Cold War, neoconservatives remain dismissive of the notion that leadership played a decisive role in ending this conflict. Those who credited Gorbachev for his role in ending the Cold War, according to Pipes, were merely peddling "an extreme version of the old theory of great men as movers of events, long ago abandoned by historians" (Pipes, 1995: 158).

Neoconservatives are right to insist that the interests of nations are not always easily reconcilable, for there are just as many instances of failed diplomacy as there are of successful diplomacy. But is it prudent to remain wedded to an ideological mindset which doubts the effectiveness of diplomacy in all instances? Even throughout the 2008 presidential election between Republican nominee, John McCain, and Democratic nominee, Barack Obama, neoconservatives endlessly excoriated what Joshua Muravchik called “Obama's Talking Cure” (2008), referring to the willingness of Obama to meet with America's adversaries. It is not so much a question of whether the likes of President Ahmadinejad of Iran is a reliable negotiating partner which arouses neoconservative suspicions, itself a reasonable question to which I turn in a later chapter; it is the very idea of summitry itself which is resisted by neoconservatives such as Muravchik:

messianic revolutionary regimes operate in a moral universe whose values are antithetical to ours. Their goal in talking is almost never to have better relations for their own sake, but to have the advantage of us. The fatal allure of transformative diplomacy is that, by means of summitry, the lions can be charmed 
not just into lying down with lambs but into becoming lambs. That goal is a chimera; it has never happened (Muravchik, 2008: 31).

The Reagan-Gorbachev relationship had little to do with the end of the Cold War, Muravchik argues, for it was only after Gorbachev appreciated the futility of competing with the West that he decided to opt out of the superpower conflict. Gorbachev's reforms, in other words, were said to be "a by-product of his encounters with Soviet reality, not with American presidents" (Muravchik, 2008: 28). Such arguments are challenged not only by the Cold War scholars mentioned above, but by prominent historians and theorists of leadership. Writing in Summits: Six Meetings that Shaped the Twentieth Century (2007), leading historian David Reynolds is under no illusions about the potential and limitations of international summitry. From the appeasement of Hitler at Munich in 1938 to Khrushchev's bluster at Vienna in 1961, Reynolds speaks frequently of the hopes betrayed by failed instances of international diplomacy. Yet the Reagan-Gorbachev relationship, he argues, was quite different. ${ }^{103}$ "Geneva in 1985," Reynolds explains, "is the story of how, implausibly and against the odds, summitry can sometimes work" (Reynolds, 2007: 343). It was the encounters between Gorbachev and Reagan, and their most senior advisors, according to Reynolds, that ensured "that the Cold War ended not with a bang or a whimper, but with a handshake" (Reynolds, 2007: 400).

To make the arguments neoconservatives do diminishes not only the impact that international summitry can have on the affairs of nations, but also the role Ronald Reagan played in ending the Cold War. The Reagan administration, as Lou Cannon, arguably Reagan's most recognised biographer, points out, was divided between hardline conservatives and pragmatists. Those at Defense, most notably Casper Weinberger and Richard Perle, were intent on embarking upon an arms race capable of crippling the Soviet Union. Negotiations were not, according to these men, expected to end or mitigate the superpower confrontation. In contrast, Reagan, according to Cannon, "recognized that he needed something to show for the build up" (Cannon, 2000: 263-265). The arms build up, he believed, was not an end in itself; it was certainly needed, for not only did the Soviet Union's behaviour warrant a

\footnotetext{
${ }^{103}$ It is important to note that even failed instances of international diplomacy reinforce the importance of national leaders, for one determined and stubborn leader has the power to derail an international summit.
} 
renewed military challenge, but hawkish domestic critics needed to be quelled.

Conservative hardliners could hardly be expected to support an agreement if they believed it had been negotiated from a position of weakness. ${ }^{104}$

Ronald Reagan, in contrast to the hardliners, saw the arms build up as a means to seeking better relations with the Soviet Union, "peace through strength" as George Shultz is fond of saying. Reagan was not an ideologue, for ideologues do not compromise their principles. In fact, even when Reagan employed his harshest anticommunist rhetoric, he was reaching out to an aging Soviet leadership, from Brezhnev to Andropov to Chernenko. ${ }^{105}$ John Lewis Gaddis concludes,

President Reagan appears to have understood - or to have quickly learned - the dangers of basing foreign policy solely on ideology; he combined militancy with a surprising degree of operational pragmatism and a shrewd sense of timing (Gaddis, 1992: 123).

Gorbachev was instrumental in ending the Cold War, but Ronald Reagan was not far behind - if indeed he was behind. There are statesmen, leadership theorist Carnes Lord explains, who should "be considered a national resource or strategic asset - one, indeed, that is too often wasted" (Lord, 2003: 157). By wanting to shackle national leaders and keep them from entering the world stage on which they have a chance to show those virtues of leadership rightly esteemed by future ages, neoconservatives deny that national leaders can ever be a "national resource" or "strategic asset." When negotiating with adversaries, American leaders must be prudent, sceptical, and even, if one is permitted to indulge in some unscholarly prose, "tough." Yet, as Carnes Lord notes, "the personal 'chemistry' of leaders can become a truly strategic factor in the relations of nations" (Lord, 2003: 157). Would Gorbachev have made the decisions he made in an international climate of superpower distrust and ideological confrontation? Perhaps, but it seems unlikely. "Reagan's greatest

\footnotetext{
${ }^{104}$ As John Lewis Gaddis puts it, "For unless one can sustain domestic support - and one does not do that by appearing weak - then it is hardly likely that whatever one has arranged with any adversary will actually come to anything" (Gaddis, 1992: 131).

${ }^{105}$ For Reagan's attempts at reaching out to the Soviet leadership, see Diggins, 2007: Ch. 10; and Leffler, 2007: Ch. V. There is, one should note, some room to criticise Reagan here. As David Reynolds points out, the Soviets found it difficult to know who the real Reagan was. Was he, for instance, the hardliner who spoke of evil empires or the Reagan who was reaching out to the Kremlin? (Reynolds, 2007: 347).
} 
contribution to ending the Cold War," according to Leffler, "was not the fear he engendered but the trust he inspired" (Leffler, 2007: 448). "Gorbachev was not awed by America's power or ideological zealotry," Leffler concludes, "but he was impressed with the president's personal character, political strength, and desire to eliminate nuclear weapons" (Leffler, 2007: 448-450).

Neoconservatives, however, live in a world in which statesmen can only ever have a marginal, perhaps negligible, impact on international politics. National ideologies and the endless quest for power, they insist, shape the behaviour of nations. This is a core part of their belief system, a part which must feature in any analysis privileging the importance of neoconservative ideas and beliefs in the realm of American foreign policy. There was one neoconservative, though, who derived an appropriate lesson from the end of the Cold War. Unlike Muravchik, Pipes, and Krauthammer, Jeane Kirkpatrick revised some of her assumptions in relation to the role national leaders can be expected to play in international politics. "The revolution in the Soviet Union should remind us," she rightly and belatedly concluded, "of the irreducible importance of individual persons in history" (Kirkpatrick, 1990b: 274).

The question of what moves history, of course, invites endless philosophical theorising. At the end of the Cold War, one distinguished IR scholar declared that history had ended, that man had reached the end point of his "ideological evolution" (Fukuyama, 1989: 4). Yet even before terrorists attacked America on September 11, neoconservatives were never persuaded by this argument. Once al-Qaeda attacked, though, neoconservatives were provided with an opportunity to renew their ideological struggles against Islamic extremism. It was an opportunity seized with alacrity.

\section{The End of History and 9-11}

Faith in liberal democratic principles is by no means an exclusive preserve of neoconservatives, but neoconservatives do display an unshakeable faith in these principles which predisposes them to global interventionism. Moynihan and Jackson were ardent defenders of America's right to meddle in the affairs of other nations, especially when the practices of those nations failed to conform to America's conception of proper internal conduct. 
They were joined, however, by many neoconservatives who forged their own paths in the 1990s, all of whom were just as prone to emphasise the importance of advancing democratic principles. Following his critique of the Carter administration's human rights campaign, Joshua Muravchik authored Exporting Democracy: Fulfilling America's Destiny (1991), a book in which Muravchik made the case for a globally active foreign policy dedicated to the expansion of liberty. In a spirit similar to that of Francis Fukuyama's argument on man's thymos - that part of man's soul which "invests objects with value," potentially leading to the bloody quest for recognition ${ }^{106}$ - Muravchik declared, "democracy has proved itself natural in the sense that it answers something innate in human nature: a longing to be treated with dignity and not to be subjected to the arbitrary rule of others" (Muravchik, 1991: 1).

Yet one should avoid overstating the degree of congruence between Fukuyama's ideas on liberal democracy as the "end point of mankind's ideological evolution" and those of neoconservatives. The neoconservative point of departure from this thesis is, in fact, worthy of some consideration. Fukuyama's thesis, at least as it was articulated in The End of History and the Last Man (1992), a book length refinement of the arguments originally made in an article published in the National Interest in 1989, provided neoconservatives with no vision of what America's role in the world should be. It fostered the impression that the world stood in no need of America, for the historical process had allegedly resolved itself and the liberal democratic idea was unchallengeably ascendant. America had become, so to speak, the dispensable nation. Fukuyama may object to such a suggestion, arguing that his thesis implied no such thing. But The End of History and the Last Man is a work of political theory, and it is therefore not immune from theoretical questions.

Neoconservatives had long asked these questions of thinkers who had attempted to write universal histories, especially Marx. "If states," asks Muravchik, "behave only as geography and human nature ordain they must, then why criticize and why prescribe?" (Muravchik, 1991: 25). "If history," in other words, "intends the triumph of the proletariat, why should Marxists labor on its behalf?" (Muravchik, 1991: 25). This, in effect, is the same question neoconservatives came to ask of Fukuyama. If the triumph of democracy was a fait accompli, what role did America have in

\footnotetext{
${ }^{106}$ This is an argument made in The End of History and the Last Man, not the original article published in The National Interest in 1989. Although this an argument to which Fukuyama returns frequently throughout The End of History and the Last Man, for an introduction to the idea of man's thymos, see Fukuyama, 1992: Ch 15.
} 
consolidating its advance? In a book which will receive much greater attention in the following chapter, Robert Kagan put it thus: "The mistake of the 1990s was the hope that democracy was inevitable" (Kagan, 2008: 99). Nothing, according to neoconservatives, could be further from the truth. Muravchik called for making the promotion of democracy the "centrepiece" of America's post-Cold War foreign policy (Muravchik, 1991: 221). From increasing foreign aid to ramping up foreign broadcasting to supporting organisations such as the National Endowment for Democracy, Muravchik provided policy-makers with a potpourri of recommendations and methods said to advance the cause of liberal democracy. In the concluding pages of Exporting Democracy, he turned his attention to the two major non-democratic powers in the international system, arguing,

In both China and the Soviet Union the old structures are crumbling, and democracy is a possible outcome. For our nation, this is the opportunity of a lifetime. Our failure to exert every possible effort to secure this outcome would be unforgivable (Muravchik, 1991: 227).

When America was attacked by al-Qaeda on September 11, 2001, even those neoconservatives who had prematurely wrote neoconservatism's "obituary" in the 1990s, and questioned the wisdom of employing American power to end intra-state violence, believed that the attacks sparked a recrudescence of ideological conflict. "September 11 felt like the initiation of a new history, but it was a return to history," Krauthammer explained, "the twentieth-century of radical ideologies and existential enemies" (Krauthammer, 2004). America's religious adversaries, in other words, fight not for the Enlightenment principles of democracy and equality. Instead, Osama bin Laden and Ayman al-Zawahiri, in the spirit of Sayyid Qutb, nostalgically exhort their followers to eschew western liberalism and punctiliously adhere to a purer Islam. While scholars and commentators attempted to penetrate the inner most thoughts of those involved in the September 11 attacks, ${ }^{107}$ neoconservatives like Krauthammer were quick to renew the war of ideology. They were also just as quick to explain why America needed to ideologically transform the Middle East. Lurking behind these

\footnotetext{
${ }^{107}$ For the best analysis of the backgrounds of the attackers and the history of al-Qaeda, see Bergen, 2002; Burke, 2003; Corbin, 2003; McDermott, 2005; and Wright, 2006.
} 
arguments, however, was the assumption that History's work is far from complete. As Kagan put it,

The focus on the dazzling pageant of progress at the end of the Cold War ignored the wires and the beams and the scaffolding that had made such progress possible. It failed to recognize that progress was not inevitable but was contingent on events - battles won or lost, social movements successful or crushed, economic practices implemented or discarded. The spread of democracy was not merely the unfolding of certain ineluctable processes of economic and political development. We don't really know whether such an evolutionary process, with predictable stages and known causes and effects, even exists (Kagan, 2008: 104).

History, in other words, does not end, and neither does the neoconservative war of ideology.

\section{$\underline{\text { World War IV and the Rise of Islamic Fascism }}$}

Casting aside his post-Cold War uncertainty about the future of neoconservatism, Norman Podhoretz re-entered the ideological fray after September 11 and during the war in Iraq, writing an article for Commentary in 2004 entitled "World War IV: How it Started, What it Means, and Why We Have To Win." Podhoretz expanded the article into a book in 2007. In World War IV: the Long Struggle against Islamofacism (2007a), Podhoretz launches a vigorous defence of the Bush Doctrine and enthusiastically frames the struggle against Islamic extremism in ideological terms. In fact, he was so enamoured of the following quotation, a quotation taken from a speech President Bush delivered before a joint sitting of the United States Congress not long after the attacks, that Podhoretz felt compelled to cite it on two separate occasions throughout this single volume: "We have seen their kind before," the President explained.

They're the heirs of all the murderous ideologies of the twentieth century. By sacrificing human life to serve their radical visions, by abandoning every value except the will to power, they follow in the path of fascism, Nazism, and 
totalitarianism. And they will follow that path all the way to where it ends in history's unmarked grave of discarded lies (cited in Podhoretz, 2007a: 9 \& 46).

For Podhoretz, there was little use in distinguishing between Muslim extremists, just as there was little use in distinguishing between rival totalitarianisms, for America's "fecklessness" throughout the 1970s, the 1980s, and the 1990s, was said to have emboldened America's jihadist enemies. Al-Qaeda's attack on September 11, 2001, was not so much the inauguration of jihadist violence against America, according to Podhoretz, as it was the culmination of a very long campaign of extremist violence, unchecked by any resolute attempt on America's part to combat an enemy who had become more and more brazen. "The sheer audacity of what bin Laden went on to do on September 11 was unquestionably a product of his contempt for American power," Podhoretz argued (Podhoretz, 2007a: 37).

Yet neoconservatives also began to promote what will be, and has become, one of the most discussed ideas leading America to Iraq. The root causes of the rage leading to the terrorist attacks on September 11, 2001, neoconservatives argue, can be found in the oppression of the Arab world. When referring to the need to promote democracy in the region, Krauthammer argued,

There is not a single, remotely plausible, alternative strategy, for attacking the monster behind 9-11. It's not Osama bin Laden; it is the cauldron of political oppression, religious intolerance, and social ruin in the Arab-Islamic world, oppression transmuted and deflected by regimes with no legitimacy into virulent, murderous anti-Americanism. It's not one man; it is a condition (Krauthammer, 2004).

Podhoretz agreed. "The 'swamps' out of which this murderous plague grew were the outcome not, as the old understanding had held, of poverty and hunger but of political oppression" (Podhoretz, 2007a: 52). The solution, all agreed, was to ideologically transform the Middle East. "It was only by 'draining' those swamps, through a strategy of 'regime change,' that we could make ourselves safe from the threat of terrorism" (Podhoretz, 2007a: 52).

Most of these arguments, it should be noted, derive from a single source, Bernard Lewis. Lewis is, as neoconservatives regularly assert, a very distinguished and 
eminent scholar of the Islamic world. He is undoubtedly a regional expert, one deserving a respectful hearing. Yet it is difficult to overstate the way in which neoconservatives lionise Lewis. All neoconservatives who attempt to illuminate the roots of al-Qaeda's brand of Islamic fundamentalism take refuge under his impressive body of scholarship. ${ }^{108}$ Lewis, of course, is a polarising figure, one not lacking in critics. ${ }^{109}$ He has walked in neoconservative circles for a number of years and has had access to senior policy-makers, including Henry Jackson, ${ }^{110}$ and senior foreign policy advisers, including many of those who served in the Bush White House. When I interviewed Richard Perle, Perle told me that the ideas of Bernard Lewis had had a significant impact on the thinking of the Bush administration. Perle was in a good position to know, for he had been the Chairman of the Defense Policy Board Advisory Committee, a committee of outside experts advising the Bush administration in the lead up to the 2003 Iraq War. If I was to only ever read one scholar on the Islamic world, Perle advised me, I best make sure that it was Bernard Lewis (Perle, interview, 23 February 2007).

Lewis has long drawn attention to the malaise of Islamic civilisation, a once prosperous, culturally advanced, militarily powerful, civilisation which had, he argued, been overtaken by the Western world. The "Renaissance, the Reformation, and the technological revolution passed virtually unnoticed in the land of Islam," Lewis explained, "where they were still inclined to dismiss the denizens of the lands beyond the Western frontier as benighted barbarians" (Lewis, 2003: 8). There were, he acknowledged, multiple traditions within Islam, some tolerant and others intolerant, but it was not up to the West to take sides. Before one of these competing

\footnotetext{
${ }^{108}$ William Bennett relies almost exclusively on Lewis when writing on Islam. Bennett had been Ronald Reagan's neoconservative Secretary of Education and acted as a mentor for William Kristol. In a chapter devoted to Islam in Why We Fight: Moral Clarity and the War on Terrorism (2003), Bennett questions whether Islamic extremism is as heretical as many wish to believe. "According to the eminent scholar Bernard Lewis, whose work I rely upon heavily here," Bennett begins, "the Islam of the September 11 'is not the true Islam. But it comes out of Islamic history and culture"' (Bennett, 2003: 90). Podhoretz also enlists the support of Lewis, describing him as "the leading contemporary authority on the history and culture of the broader Middle East" (see Podhoretz, 2007: 3 \& 6).

${ }^{109}$ Of course, the most famous is Edward Said. For an introduction into Said's views on Lewis and Orientalism, see Said, 2004. Also, for a very good overview of the debates between Lewis and Said, see Doogue \& Kirkwood, 2005: 118-130.

${ }^{110}$ Lewis even authored a chapter on Jackson's relationship with Israel in Staying the Course: Henry M. Jackson and National Security (1987), a celebratory collection of chapters assembled by Dorothy Fosdick, one of Jackson's long term aids. It is a book which celebrates Jackson's legacy in foreign affairs. See Lewis, 1987: 129-141. According to Robert Kaufman, Jackson's biographer, it was Richard Perle, another key Jackson aide, who first introduced Lewis to the world of Washington policy-makers. Lewis became, according to Kaufman, "the Middle East expert on whom he (Jackson) relied the most" (Kaufman, 2000: 372).
} 
traditions won the soul of Islam, Lewis had argued in an influential article in 1990, "there will be a hard struggle in which we of the West can do little or nothing. Even the attempt might do harm, for these are issues that Muslims must decide among themselves" (Lewis, 1990/2005: 412). ${ }^{111}$

As the 1990s moved along and Lewis published What Went Wrong? Western Impact and Middle Eastern Response (2002), he became more and more pessimistic about the prospects of the Islamic world recovering its erstwhile greatness. "If the people of the Middle East continue on their present path," he ominously concluded just before the September 11 attacks, "the suicide bomber may become a metaphor for the whole region" (Lewis, 2002: 178). ${ }^{112}$ After September 11, Lewis, notwithstanding his earlier reluctance to see the West intervene in intra-Islamic disputes, became a leading advocate for ideologically transforming the Middle East. The affect of September 11 on Lewis was large indeed. There are, he argued, "few acts of comparable deliberate and indiscriminate wickedness in human history" (Lewis, 2004: 132). It was time, Lewis concluded, for America to distance itself from Middle Eastern autocrats and stand on the side of those calling for greater freedom in the region. "It is surely significant," he declared, "that all the terrorists who have been identified in the September 11 attacks on New York and Washington came from Saudi Arabia and Egypt - that is, countries whose rulers are deemed friendly to the United States" (Lewis, 2004: 102).

Yet throughout The Crisis of Islam: Holy War and Unholy Terror (2004), a follow up publication to What Went Wrong and a book which dealt more directly with the September 11 terrorist attacks, Lewis began proposing something much more ambitious than a mere withdrawal of support from Middle Eastern autocrats. He was proposing the transmogrification of Middle Eastern political culture. In a culture characterised by extravagant conspiracy theories and wanton violence, America, according to Lewis, needed to stand with those Muslims ready to defend liberal democracy, fostering in the process the liberal democratic values of compromise and toleration of social diversity:

\footnotetext{
${ }^{111}$ This quote was taken from an article published in 1990 entitled 'The Roots of Muslim Rage.' It was an article republished in its entirety in Babel and Dragomans: Interpreting the Middle East (2005).

${ }^{112}$ What Went Wrong was being published at the time of the September 11, 2001 attacks. Lewis, as I explain, deals more fully with these attacks in The Crisis of Islam: Holy War and Unholy Terror (2003).
} 
In two countries, Iraq and Iran, where the regimes are strongly anti-American, there are democratic oppositions capable of taking over and forming governments. We, in what we like to call the free world, could do much to help them, and have done little. In most other countries in the region, there are people who share our values, sympathise with us, and would like to share our way of life. They understand freedom and want to enjoy it at home. It is more difficult for us to help those people, but at least we should not hinder them. If they succeed, we shall have friends and allies in the true, not just diplomatic, sense of these words (Lewis, 2004: 140).

The arguments of Bernard Lewis were bound to be echoed by his neoconservative eulogizers. Neoconservatives had long spoken about the importance of attempting to cultivate liberal democratic values in other national societies. They have regularly endorsed the central conclusion of what liberal IR theorists have called the "Democratic Peace Thesis," namely, that liberal democracies are more pacific in their dealings with each other than they are with other regime types. ${ }^{113}$ Whether it is the restraints imposed by democratic institutions and the need for popular support before rulers can wage wars, or confidence in the pacifying effects of liberal values, democratic political cultures, according to neoconservatives, produce peaceful states and peaceful citizens. ${ }^{114}$ The "ethics of democracy," according to Muravchik, "conduce to peace." "Once individuals have internalized these ethics in their behaviour within the polity," he explained, "they can readily see that the same

\footnotetext{
${ }^{113}$ This is a debate which often pits liberal IR theorists against many structural realists, who, following Kenneth Waltz, deprecate the role that internal factors play in a nation's foreign policy. For Waltz's views on international conflict and the internal structure of states, or what he calls the "second image" of international politics, see Waltz, 1959: Ch. IV. For a Kantian liberal perspective on the democratic peace thesis, see Doyle, 1996: 3-58. For a sceptical appraisal, see Lane, 1994; and Rosato, 2003. For an excellent overview of the debates, see the assembled chapters in Debating the Democratic Peace (1996), ed. M. Brown, S. Lynn- Jones, and S. Miller.

${ }^{114}$ These are essentially the two most frequently cited explanations for the democratic peace, both of which are often endorsed by neoconservatives. For a good overview of the literature which explains how liberal norms and democratic structures moderate the foreign policies of liberal democracies even though there is no consensus within this literature as to which explanation is best able to explain the Democratic Peace - see, Reiter \& Stam, 2002: 197-202; Russet, 1996: 90-116; Sharansky, 2004: 76-82; and Weart, 1998: Ch. 5. The structural explanation, one could argue, is somewhat contestable. Arthur Schlesinger's Imperial Presidency, a book in which Schlesinger argues that modern American presidents have usurped a degree of power deeply at odds with the wishes of America's founders, implicitly challenges the structural argument. The most one can say for this explanation, I believe, is that it makes it more difficult for democracies to wage war, not impossible. See Schlesinger, 2004.
} 
principle can apply to relations among states" (Muravchik, 1991: 9). ${ }^{115}$ "Democratic nations,” Kirkpatrick agreed, “don't start wars” (cited in Stelzer, 2004: 10). Even Charles Krauthammer, a neoconservative more intoxicated with power politics than the zealous promotion of democracy, endorses the thesis. "Democracies," he argued, "are inherently more friendly to the United States, less belligerent to their neighbours, and generally more inclined to peace" (Krauthammer, 2004).

Yet neoconservatives rarely examine this thesis in any thorough way. It is their sense of America's national mission which leads them to uncritically embrace ideas calling for the expansion of democracy around the world. As Kagan put it, "For the day we adopt a neutral attitude toward the fate of democracy in the world is the day we deny our own essence, an essence rooted in a commitment to certain principles which we believe to be universal" (Kagan, 1997: 26). In fact, long before September 11, Kagan was calling for America to distance itself from Middle Eastern autocrats and to support progressive movements within the Arab world. We "could and should," he claimed, "be holding authoritarian regimes in the Middle East to higher standards of democracy, and encouraging democratic voices within those societies, even if it means risking some instability in some places" (Kagan, 1997: 26).

The article in which Kagan makes this argument is entitled "Democracies and Double Standards" (1997), an article which deliberately attempted to position itself in direct opposition to Jeane Kirkpatrick's "Dictatorship and Double Standards." Yet it is important to note that Kirkpatrick was every bit as ideological as Kagan. An ideologized foreign policy can lead to many different policy recommendations. It can lead one neoconservative (Kirkpatrick), writing at a particular time, to call on America to align itself with morally unsavoury regimes and forces capable of resisting the greatest ideological threat to liberal democracy, just as it can lead other neoconservatives (Kagan and Muravchik), writing at a different historical juncture, to call for the adoption of a foreign policy dedicated to the expansion of liberty. Analysed superficially, Kirkpatrick's scepticism in relation to democracy promotion

\footnotetext{
${ }^{115}$ The normative explanation for the democratic peace, it should be noted, aims to explain why both democracies produce peaceful citizens and peaceful states. It is, therefore, directly relevant to debates centring upon democratisation in the Middle East. Democratic values, neoconservatives argue, not only push democracies to cooperate and compromise, but they also produce more peaceful citizens, reducing the risk of Islamic extremism. As Muravchik put it, "the mechanics of democracy would also have a socialising or re-socialising effect; people would just get used to do doing business in this way where you debate and cut deals and vote rather than shoot" (Muravchik, interview, 20 February 2007).
} 
does appear to be in direct opposition to Kagan's democratic zeal. ${ }^{116}$ There is certainly a practical difference, but it is not a difference produced by any less of a commitment to the neoconservative war of ideology.

After September 11, neoconservatives, echoing Lewis and inspirited by the appearance of another ideological foe requiring defeat, located the roots of Islamic extremism in the Middle East. There was an assumption that the political culture of the Arab world was producing irrational and violent citizens. Eager to renew the war of ideology, most neoconservatives (with the exception of Kirkpatrick and probably Irving Kristol) instinctively supported the idea of reforming oppressive societies that were considered to be breeding "fanatical religious zealots." It was an idea appealing to their idealistic sensibilities. As William Kristol put it in a 2004 speech,

I advocate promoting democracy, a liberal democracy, much more than we did over the preceding two or three decades when we, as a bipartisan matter, decided that basically dictators that we could work with were fine and we could live with the consequences of propping up those dictators. Among the consequences was dissatisfaction at home and the ability of people like Osama bin Laden to recruit dissatisfied people (Kristol, 2004a: 25).

The dilemma of religion and politics, faith and violence, piety and terrorism, however, has been a dilemma scrutinised by some of the most erudite scholars. ${ }^{117}$ Two in particular, Olivier Roy and Farhad Khosrokhavar, challenge the ideas of regional experts such as Bernard Lewis and neoconservative foreign policy thinkers. These scholars emphasise the global dimension of al-Qaeda's war, rejecting the idea that the roots of the war on terror can be located exclusively, if at all, in the political culture of the Middle East. Deracinated, uprooted, living as a minority in countries in the West, many Muslims are said to be experiencing "the deterritorialisation of Islam" (Roy, 2004: 2). Bin Laden himself attempted to speak not on behalf of any national project, but on behalf of a global community of Muslims who live in a world without

\footnotetext{
${ }^{116}$ It was, it will be recalled, Kirkpatrick who regretfully acknowledged, "no idea holds greater sway in the mind of educated Americans than the belief that it is possible to democratize governments, anytime, anywhere, under any circumstances" (Kirkpatrick, 1979/1982: 30).

${ }^{117}$ For two of the most authoritative studies, see Juergensmeyer, 2001; and Stern, 2003. While neither of these studies focuses exclusively on al-Qaeda and Islam, they do provide excellent analyses of the mind of the religious militant. For an analysis of the relationship between Islam - or the various sects within Islam - and terrorism, see Bonney, 2004; Delong Bas, 2004; and Esposito, 2003.
} 
borders. His 1996 Declaration of War against America is peppered with references to the Muslim Ummah, the global community of all true believers. ${ }^{118}$

Notwithstanding some long standing grievances he has with the Saudi monarchy, bin Laden's war is de-linked from any territorial demand. As Farhad Khosrokhavar put it when describing the ambitions of al-Qaeda, "The network has no concrete project other than fighting the West, and no specific platform. Its goal is not to form a government in any specific state" (Khosrokhavar, 2005: 166). As the towering symbol of the modern world, America is the prime target. As Roy argues, "with Bin Laden there is no room for negotiation. His goal is simply to destroy Babylon" (Roy, 2004: 56). Reforming societies in the Arab world and transforming their citizens into "moderate" and "civilised" liberal democrats, in other words, will have little appreciable impact on al-Qaeda's brand of martyrdom. "The time and space of modern Islamic radicalism," Roy explains, "is emancipated from the Middle East. It is a global space" (Roy, 2004: 13).

Holding regimes in the Middle East to higher standards of liberal democracy, of course, may very well be a worthy national undertaking, one requiring a debate over means, methods, and timing. Furthermore, it is certainly true, and has long been a staple of philosophical thinking, that the nature of political regimes help shape the character of the citizens living under them. ${ }^{119}$ Yet what is so alarming about the terrorist attacks on September 11, 2001, is that many of the men who carried out the attack, true to Roy's and Khosrokhavar's portraits, were citizens of the modern world. It was not that they had no experience with the West and were driven to extremes by oppressive Arab governments. Most members of the Hamburg Cell, the small group of men living and studying in Germany who became the ring-leaders of the attack, underwent their process of radicalisation in the West. The men left their home

\footnotetext{
${ }^{118}$ Bin Laden issued two declarations of war against America, the first in 1996 and the second in 1998. See bin Laden, 1996; 1998. Bin Laden, I believe, has always been more of a global jihadist committed to fighting global superpowers, as opposed to a jihadist fighting to topple "domestic apostates" such as Saudi Arabia. Montasser al-Zayyat, Ayman al-Zawahiri's biographer, extensively discusses bin Laden's influence on al-Zawahiri. He concludes, “Zawahiri's alliance with Osama bin Laden changed his philosophy from one prioritizing combat with the near enemy to one of confronting the far enemy: the United States and Israel" (al-Zayyat, 2004: 70). For a contrary argument, one stressing the importance of territory (although I believe it has been successfully rebutted by the likes of Roy and Khosrokhavar), see Pape, 2005a. For an interesting depiction of bin Laden, as it has been conveyed through the words of those who have known him, see Bergen, 2006. For an early biography on bin Laden, see Bodansky; 2001. For a thorough and comprehensive portrait of the bin Laden family, which includes a detailed summary of the life of bin Laden's brother, Salem bin Laden, see Coll, 2008. ${ }^{119}$ Although this discussion takes one into the realm of political philosophy, from Plato to Aristotle to de Tocqueville, for a very good contemporary study on how the character of regimes affects the character of the citizens living under them, see Codevilla, 1997.
} 
countries in the Middle East, settled in Germany, failed to integrate, attended the radical al-Quds mosque, and, in the words of Khosrokhavar, formed "bonds" said to be "based upon friendship and cultural closeness" (Khosrokhavar, 2005: 167).

These men were not radicalised by their experiences with the oppression in the Arab world, just as they were not radicalised by some uncontrollable rage born of America's support for select Middle Eastern autocrats. The likes of Mohammad Atta, Ramzi-Binalshibh, Marwan al-Shehhi, and Ziad Jarrah, all of whom were key players in the attack, had initially left Germany in the 1990s and were headed to fight the Russians in Chechnya. It was not until a series of "fortuitous" meetings, as reported by The 9/11 Commission Report (2003), that they were redirected to Afghanistan, accepting the mission bin Laden gave them in December of 1999 - the mission culminating in the September 11 terrorist attacks against America. (The 9/11 Commission Report, 2003: 165-167).

To the extent that they thought about America, these men, like so many others attracted to al-Qaeda's vision, see the world's sole superpower as the head of an international system which exploits the Muslim world and corrupts Islamic mores. As Khosrokhavar put it,

They cannot understand how it is possible to both watch the repression of the Muslim world on television, and live peacefully in a world of arrogant wealth and immoral complicity with the oppressors without raising their voice in protest" (Khosrokhavar, 2005: 161).

Terry McDermott, an investigative journalist for the Los Angeles Times who spent years retracing the steps of the men involved in the September 11 attack, draws attention to the degree to which al-Qaeda's war is not confined to any geographical space. He does this by emphasising the content of some of the discussions these men had at the al-Quds Mosque in Germany. "As time went on," McDermott explained, "the focus on religion became almost an obsession within the group," adding,

Discussions intensified, although, friends said later, they were scattershot. One week, the members were intent on fighting in Kosovo, the next in Chechnya or Afghanistan or Bosnia. The men agreed: they wanted to fight - they just didn't know which war (McDermott, 2005: 65). 
The neoconservative war of ideology, a war leading many neoconservatives to assume that the roots of modern international terrorism could be found and tackled in the Arab world, prevented neoconservatives from engaging in any reasoned debate about the motives of those who carried out the terrorist attacks on September 11, 2001. The phenomenon of Islamic suicide terrorism is more complex than the ideological appraisal offered by neoconservatives suggests. As young Arab men encounter the "free world," it is alarming to think that al-Qaeda's brand of martyrdom may be attributable more to the interactions these young men have in the West than to their individual experiences in the Arab world. ${ }^{120}$ "The ripest recruits for suicide missions," according to some, are "half-way men, stuck in transit between the Middle East and the West, whose frustration is mingled with a feeling of being tainted by a society that seduces them" (Holmes, 2005: 319). Yet it was precisely the belief that the roots of modern international terrorism could be found in the Middle East that led neoconservatives to support the 2003 Iraq War. There was never any doubt among the most vocal neoconservatives, in fact, that America should go to Iraq. As Krauthammer put it just days after September 11,

The war on terrorism will conclude in Baghdad. How? No one knows. All we do know is that history, cunning and cruel, will demand that if this president wants victory in the war he has declared, he will have to achieve it on the very spot where his father, 10 years ago, let victory slip away (Krauthammer, 2001a).

Neoconservatives are not entirely wrong when they speak of the importance of cultivating liberal democratic values, both in America and abroad. The world has certainly seen the consequences of political cultures which preach hatred of other national societies and embattled minorities. ${ }^{121}$ Yet by presenting the democratisation of the Middle East as the panacea for Islamic extremism, neoconservatives promoted a questionable policy prescription which cannot withstand serious scrutiny, a

\footnotetext{
${ }^{120}$ For an interesting discussion on the cultural difficulties young Arab men have when encountering the West, and the internal clash of civilizations it can sometimes produce, see Holmes, 2005: Ch. 4. ${ }^{121}$ Anyone familiar with Daniel Goldhagen's Hitler's Willing Executioners would appreciate the degree to which the fostering of a particular political culture can influence the way in which minorities are spoken about and treated. For an analysis of how German "eliminationist Antisemitism" evolved and permeated German political culture, see Goldhagen, 1997: Ch. 2. For useful insights into the culture of violence in the Palestinian territories, and its deleterious affect on young Palestinians, see Oliver \& Steinberg, 2006.
} 
prescription underlaid by a remarkable amount of liberal faith in the perfectibility and malleability of man. Democratising Middle Eastern regimes, many neoconservatives believed, would produce a new Arab citizen, one not compromised by religious extremism and fanaticism. This was, to put it mildly, an ambitious undertaking. There is a large amount of validity to Francis Fukuyama's observation that neoconservatives, just like those serving in the Bush administration, became far too confident in their capacity to socially engineer not only Iraq, but the entire Middle East (see Fukuyama, 2006: 6-7).

When I asked Joshua Muravchik whether the 2005 London bombings, in which the attacks on London's public transport system were carried out by home-grown Islamic extremists, posed any challenges to the neoconservative belief in the power of liberal values to produce "moderate" citizens, he conceded that "the London bombing in particular is a very powerful challenge to the theory behind what we were advocating doing" (Muravchik interview, 2007). The terrorist attack in London, he added, was a "frightening one," because even if the "experience of being raised in Britain" fails to "inoculate against this ideology....then I'm not sure what we do" (Muravchik, interview, 20 February 2007).

Notwithstanding Muravchik's nascent doubts, many neoconservatives continue to talk about liberalising the Arab world. Kagan, for instance, insists that America should "address Islamic radicalism by accelerating and intensifying its confrontation with the modern globalized world" (Kagan, 2008: 101). Armed with the hope that people raised in a democracy would think in a more pacific way, neoconservatives were confident that democratising Iraq would have a profound impact on the characters of Middle Eastern citizens. Although I examine this conflict in a later chapter, one thing is beyond cavil: as neoconservatives fiddled with their liberal theories of human nature, Iraq burned.

\section{$\underline{\text { Conclusion }}$}

This chapter has critically engaged with the neoconservative war of ideology. This is a core aspect of the neoconservative approach to American foreign policy, an aspect which should constitute a very important part of the way in which neoconservatism is thought about. The chapter began by reviewing the ideological challenge Daniel Patrick Moynihan issued at the United Nations, and examined the ideas behind Henry 
Jackson's quest to link human rights improvements in the Soviet Union with promises of greater trade.

The neoconservative advocacy of an ideologized foreign policy, I argued, is not always conducive to reasoned debate and prudent analysis. Their ideological dogmatism led to their belief that the Soviet Union was an irredeemable totalitarian superpower and a permanent fixture of the international system, making dialogue an exercise in utopian otiosity. It also led to a very questionable embrace of ideas purportedly explaining the root causes of al-Qaeda's brand of Islamic jihadism. These beliefs did not reflect well on those calling for an ideologized foreign policy. In fact, there is considerable tension between the two. As John Patrick Diggins put it, "the same neocon hawks who denied that Russia could change have persuaded Americans that their country has the means to go almost anywhere in the world and bring about "regime change"' (Diggins, 2007: xxi).

Soviet communism did, at least to a degree, require the West to accept that ideology could not be relegated to the sidelines in international politics. Totalitarian ideas must always be taken seriously, both because of their capacity to stir up trouble in the world and because of their inherent perniciousness. "You had to live - did live," George Orwell argued when explaining in his masterpiece, Nineteen EightyFour, the affect Big Brother had on the lives of those under its omnipresent eye, "from habit that became instinct - in the assumption that every sound you made was overheard, and, except in darkness, every movement scrutinised" (Orwell, 2005: 5).

When liberal democracy is deserving of a defence before its ideological competitors, it should receive one. Yet one must not succumb to a form of ideological thinking that prevents one from seeing the possibilities of pragmatic accommodations, and the true nature of one's enemies. In the 1980s, Daniel Patrick Moynihan may have moved away from some of the ideological arguments he made earlier in his career, but many neoconservatives remain just as committed to the war of ideology. And it was Moynihan, after all, who inspired so many of them. Liberal democratic principles, Moynihan once argued, must be defended "prudently if possible, but at the risk, if need be, of imprudence" (Moynihan, 1974: 28). Moynihan may have excused himself from the neoconservative war of ideology in the mid1980s, but given the degree to which the neoconservatives who followed him emulated his ideological combativeness, it would not be unreasonable to conclude that he was given an honourable discharge. 


\section{Chapter 5 \\ International Order and American Preponderance}

Whether it is liberal critics of neoconservatism such as Gary Dorrien or paleoconservative critics such as Patrick Buchanan, few have resisted the urge to return and analyse the contents of the 1992 Defense Planning Guidance (DPG), often presenting the document as a precursor to the Bush administration's 2002 National Security Strategy and the inauguration of the neoconservative quest for a pax-Americana. ${ }^{122}$ Rarely, though, has this literature examined the extent to which neoconservative critiques of détente paved the way for the arguments of the neoconservative unipolarists writing in the 1990s. It was, after all, throughout the Nixon-Kissinger era of détente that neoconservatives began to emphasise the importance of attaining and preserving American military preponderance. This chapter, therefore, moves away from some of the more idealistic features of neoconservatism, entering instead the realm of neoconservative ideas on American power and primacy.

Support for a unipolar order, a key feature of post-Cold War neoconservatism, cannot be understood unless one returns to the era of détente and examines the set of ideas embedded in neoconservative critiques of the Nixon-Kissinger administration's attempt to forge a multipolar world in which no state predominated. The administration's attempt to embrace and forge a multipolar world, I explain, did not mean that America would no longer retain a unique position in the international system. Contrary to several neoconservative portrayals, the Nixon-Kissinger administration sought to preserve a unique role for America in the world, a role many neoconservatives regularly deprecated and often considered tantamount to appeasement. ${ }^{123}$ What is important to note, however, is the way in which neoconservatives on both sides of the Cold War identified threats requiring the attainment and preservation of American military preponderance. For neoconservatives throughout the Cold War, the messianic zealousness of the Soviet

\footnotetext{
${ }^{122}$ For the way in which these two authors presented this document, see Chapter Two.

${ }^{123}$ It is not possible, it must be noted, for this chapter to examine all the arguments of Kissinger's scholarly writings, or delve too deeply into President Nixon's early career. For a greater understanding of the ideas Kissinger developed as a scholar, ideas relating to order, legitimacy, and the problem of statecraft as they were confronted by statesmen such as Metternich and Castlereagh, see Kissinger, 1964. For a useful overview of Kissinger's writings before he entered government, see Graubard, 1973. Finally, for an interesting look at the beliefs Kissinger developed as a scholar and how they influenced his decision-making throughout the Vietnam War, see Walker, 1977.
} 
Union was said to require a strong and preponderant America capable of resisting Soviet advances. For neoconservatives throughout the 1990s, the threat was said to inhere more in the structure of the international system and the potential for the world to revert back to a destabilising period of global multipolarity. International order, neoconservatives argue, is fragile. It is a product, they insist, of American power. Before that argument is examined, however, I begin with an analysis of the ideas which evoked their steadfast opposition.

\section{Nixon, Kissinger \& the Balance of Power}

On August 8, 1974, President Richard Nixon, consumed and beset by the unfolding saga of Watergate, resigned. He "bequeathed to Ford," noted John Greene, "a foreign policy that had begun a thorough reassessment of America's place in the world" (Greene, 1995: 117). It was a reassessment shaped by both the ideas of Richard Nixon and Henry Kissinger, Nixon's National Security Adviser and eventual Secretary of State, and the domestic and international environment within which they were compelled to operate. ${ }^{124}$ There is no doubt that America's experience in Vietnam engendered a national listlessness which precluded the possibility of a renewed global activism. Nixon and Kissinger themselves often spoke of the constraints under which they were forced to operate. ${ }^{125}$ Not wanting to abandon America's international role, their challenge, in Kissinger's words, was "to find some sustainable ground between abdication and overextension" (Kissinger, 1994: 704). Finding this ground in détente, Nixon and Kissinger fashioned an approach to American foreign policy that would focus on the core and the periphery, an approach guided by the idea of a global balance of power and a stable equilibrium.

The idea of a global balance of power was at the heart of the Nixon-Kissinger approach to American foreign policy. It was an idea that was a product of both a normative judgement as to what best preserves stability, and a detached analysis of an emerging international order within which multiple poles of power were said to exist, requiring recognition of national limits. In an interview with Time magazine in early 1972, Nixon explained, "I think it will be a safer world and a better world if we have a

\footnotetext{
${ }^{124}$ For a good assessment of these contexts, see Garthoff, 1994: Ch. 1.

${ }^{125}$ Kissinger regularly cites both domestic lethargy and the emergence of a complex multipolar world in which America could no longer predominate as two of the constraints he and Nixon faced. On the first point, see Kissinger, 2000: 96. On the second, see Kissinger, 1994: 703-704.
} 
strong, healthy United States, Europe, Soviet Union, China, Japan, each balancing the other, not playing one against the other, an even balance" (Nixon, 1972: 15). While it is somewhat debateable as to whether Nixon supported a world in which America refrained from manipulating the behaviour of other powers, he does regularly emphasise a common theme. "It is when one nation becomes infinitely more powerful in relation to its potential competitor," Nixon warned, "that the danger of war arises" (Nixon, 1972: 15). A world dominated by a single power, according to Nixon, imperilled stability and enhanced the prospects of great power war. Such an argument is consistent with one of the key tenets of balance of power theory, namely, that no state should be permitted to attain supremacy or predominance over the international system. "This is the single most important theme," argues one IR theorist, "in the balance of power literature" (Levy, 2004: 32).

Under the Nixon-Kissinger administration, America was groomed to play the role of "holder of the balance," a position from which alliance partners were selected not on a punctilious adherence to ideological criteria, but on the basis of a conception of the national interest opposing the predominance of any one state. It was also a position from which America could influence and shape the behaviour of other powers, including the Soviet Union and Mao's China. For Robert Dallek, the most recent historian to plumb the depths of the Nixon-Kissinger relationship, the administration's opening to China, of which Kissinger was an integral part, "was a wise act of statesmanship," a conclusion Dallek considers incontestable and shared presumably by all serious students of international politics (Dallek, 2007: 617). Irrespective of the merits of this argument, the administration's opening to China was undoubtedly a deliberate attempt, of which Kissinger speaks frequently, to manipulate the global balance of power in order to prevent the Soviet Union from achieving global hegemony. The most important objective of the administration was to align America with the weaker of the two superpowers (China) in order to balance the stronger (the Soviet Union), an objective many IR theorists consider part and parcel of balance of power politics. ${ }^{126}$ "In its new approach to foreign policy," Kissinger explained, "America was not about to back the stronger against the weaker in any balance-of-power situation" (Kissinger, 1994: 730).

\footnotetext{
${ }^{126}$ For an elaboration on this point, and one which I will develop later in this chapter, see Walt, 1987: 18-21).
} 
Yet the opening to China was not an end in itself. It was a policy reversal which aimed to foment changes in the Soviet Union's willingness to enter into a period of rapprochement with America, facilitating a lasting détente between the two superpowers. The move "toward China," Kissinger declared, "was not to collude against the Soviet Union but to give us a balancing position to use for constructive ends - to give each Communist power a stake in better relations with us" (Kissinger, 1979: 192). This suggested that underlying the administration's attempt to forge a global balance of power in which no state achieved military preponderance was the assumption that the Soviet Union no longer posed the same level of threat it once did, precluding the possibility of peaceful coexistence. "I have always believed," Nixon explained somewhat questionably in his memoirs, "that we can and must communicate and, when possible, negotiate with communist nations" (Nixon, 1978: 344). A global balance of power was, after all, only possible if all the major powers in the international system accepted what Kissinger described in his doctoral dissertation as the "legitimacy" of the prevailing international order, making negotiations and the reconciliation of interests - the art of diplomacy, in other words a possibility (see Kissinger, 1964: Ch. 1).

By trying to achieve an accommodation with the Soviet Union, however, an accommodation involving superpower summits, multiple arms control agreements, and the proffering of American political and economic concessions in return for what was hoped to be Soviet restraint, Nixon and Kissinger tacitly conceded that the administration did not consider the Soviet Union a revolutionary superpower. ${ }^{127}$ Neoconservative critics of the Nixon-Kissinger conception of détente rejected such a notion, claiming instead that the Soviet Union was not a status quo power capable of moderating its conduct, but an inveterate totalitarian adversary. In his memoirs, Kissinger would speak of the neoconservatives in a tone that was at once both respectful and critical. "Tactics," he concluded, "bored them; they discerned no worthy goals for American foreign policy short of total victory" (Kissinger, 2000: 107). They also discerned no ideational goals short of a complete discrediting of the idea of détente and all that it implied.

\footnotetext{
${ }^{127}$ For an excellent overview of what détente entailed, including the agreements it led to and the concessions the US made, see Gaddis, 2005: Ch. 9 \& 10.
} 


\section{The Neoconservative Response}

Henry Jackson's wrangling with the Nixon-Kissinger administration over the Jackson-Vanik amendment was part of a much broader project of derailing détente with the Soviet Union. Jackson himself had had a long and distinguished career, throughout which he had been slated to serve in both Democratic and Republican administrations, first as John F. Kennedy's Vice Presidential running mate in 1960 and then as Richard Nixon's first term Secretary of Defense in 1968. For a variety of reasons, Jackson had to content himself with a congressional career which spanned several decades, and two failed presidential bids in 1972 and 1976. He was the quintessential Truman Democrat, fiercely anti-communist and more than capable of mastering the recondite details of the most complex arms control agreements. The fact that Jackson, who would become such a strident critic of the Nixon-Kissinger conception of détente, was a serious candidate to serve in the Nixon administration as Secretary of Defense tempts one to consider what the fate of détente would have been had such a course of events transpired. As it was, Jackson remained on the sidelines, chipping away, where he could, at a policy he disdained. "Despite his assurances that he would have supported a genuine détente," noted Robert Kaufman, Jackson's admiring biographer, "Jackson did truly intend to subvert that policy during the 1970s" (Kaufman, 2000: 299).

To subvert the policy of détente, Jackson accentuated the Soviet Union's expansionist tendencies, its ideological fervour, and its insatiable lust for power. It was not a power, in Jackson's presentation, willing to accommodate itself to the international system. At the height of the debates surrounding détente, Jackson was aware, according to Kaufman, "that the Soviet Union no longer engaged in the rampant terror emblematic of Stalin's times" (Kaufman, 2000: 248). Yet he was still said to have "considered the Soviet Union a totalitarian state, a malevolent Leninist driven entity with unlimited aims and ambitions, not the traditional great power that Nixon and Kissinger considered it" (Kaufman, 2000: 248). Jackson's belief that the Soviet Union was a hostile totalitarian state was one which had not wavered throughout the course of his congressional career. "The Soviet rulers think in terms of power," he explained in a speech delivered throughout the concluding years of the Eisenhower administration, adding, 
Superior power, they believe, will eventually prevail. In every way, on every occasion, they seek to expand and consolidate their strength, confident that small gains here and there, at the margins of conflict, will determine the fate of the world (Jackson, 1959/1990: 64).

If Jackson sought to subvert the policy of détente from the floor of the Senate, neoconservative intellectuals waged their struggles in the pages of Commentary. ${ }^{128}$ In their doomsday presentation, neoconservatives argued that there were simply no lengths to which the Soviet Union would not go in order to satisfy its great power ambitions. For those unfamiliar with the contents of an article written by Richard Pipes in 1977, it is difficult to convey much less overstate the degree to which he feared and expected a Soviet nuclear first strike. A nuclear pre-emptive strike was a very real possibility, according to Pipes, because Soviet strategic doctrine was not underlaid by the same set of assumptions which had guided American thinking about the undesirability and futility of nuclear war. "There is something innately destabilizing in the very fact that we consider nuclear war unfeasible and suicidal for both," claimed Pipes, "and our chief adversary views it as feasible and winnable for himself" (Pipes, 1977: 34). Although there is no consensus in the scholarly and historical literature as to whether the Soviet Union's behaviour under the stewardship of Leonid Brezhnev confirmed neoconservative threat assessments, neoconservatives remained immovable in their conviction that the Soviet Union was an irredeemable totalitarian adversary committed to global domination. ${ }^{129}$

Having defined the Soviet Union in such apocalyptic terms, neoconservatives were eternally vigilant, always searching for confirmation that the Soviet Union was incapable of acting responsibly and with restraint. Its involvement in the 1973 Yom Kippur War, a war waged by Egypt and Syria against Israel in order to reclaim lost territories and restore Arab pride following a string of humiliating defeats, was

\footnotetext{
${ }^{128}$ While there were many articles written which reflected on the value of détente and the arms control agreements achieved throughout this period, for a useful sample, many of which I draw on below, see Draper, 1974; 1976; Laqueur, 1975; Pipes, 1977; 1980; Rostow, 1979; and Podhoretz, 1982a.

${ }^{129}$ For a detailed and balanced appraisal of the Soviet Union's policies throughout the Cold War and throughout the period of détente, one which also questions the neoconservative assessment of the Soviet threat, see Zubock, 2007: Ch. 7 \& 8. Zubock's views on Brezhnev challenge many of the conventional interpretations, especially those of neoconservatives.
} 
regularly cited as confirmation of the "illusions" of détente, and the duplicity and nefariousness of the Soviet regime. ${ }^{130}$

Confirmation was also said to be found in the Soviet Union's penchant for treating the arms control agreements reached throughout this period as a cover below which they could continue their enormous arms build up. ${ }^{131}$ Jackson, for instance, feared that the SALT 1 Treaty, the treaty which froze the amount of offensive weapons each superpower had at its disposal, placed America in a position of "strategic inferiority" (Jackson, 1972/1990: 139). The concern, in short, was that America was falling behind, the Soviet Union was racing ahead, and the Nixon-Kissinger administration was prepared to permit the Soviet Union to accumulate and brandish a degree of global power that was sure to put America on the defensive.

What lurked behind these concerns and depictions of the Soviet Union, however, was a collective mindset that disdained utopian meliorism and believed in the permanent presence of great power politics, a mindset which outlived the Cold War. As Walter Laqueur put it in the pages of Commentary,

Those who demand that U.S. policy be oriented toward the United Nations, or toward an illusory détente, or who maintain that military power is no longer of consequence, or that global conflict is bound to lessen, have moved beyond politics to a world in which anything is possible, and anything can be said (Laqueur, 1975: 50).

This assessment of the Soviet threat, not to mention the mindset that disdained all forms of utopian meliorism, contributed to the neoconservative investment of faith in American power. Throughout the Nixon-Kissinger years of détente, neoconservatives also began to question the Nixonian assumption that war was a product of a world in which one state predominated. Order, they argued, was the product of the exertions of a benign and preponderant hegemon, not a world characterised by global multipolarity. This is one of the most important ideas and beliefs which must be

\footnotetext{
${ }^{130}$ For an article which questions Kissinger's diplomatic manoeuvrings throughout this war, see Luttwak \& Laqueur, 1974. For an article which examines the implications of this war, an article which begins by arguing that "The October war in the Middle East was a Pearl Harbor, an explosion which revealed acute tensions between reality and the models for reality which have dominated many minds," see Rostow, 1974. Finally, for an excellent historical analysis of the war and the role of the two superpowers in furnishing aid to their clients, see Morris, 2002: Ch. 8.

${ }^{131}$ See Jackson, 1972/1990: Ch. 11.
} 
critically examined in any study seeking to understand the neoconservative approach to American foreign policy. After all, it was a core neoconservative idea which straddled both sides of the Cold War.

\section{Balances of Power and Imbalances of Power}

Henry Jackson's critique of détente was multifaceted. It ranged from his concern that the Nixon-Kissinger conception of détente downplayed the importance of human rights within the Soviet Union to the belief that the Soviet Union was still a totalitarian adversary bent upon global aggrandisement. ${ }^{132}$ There was, however, one significant criticism shaped by Jackson's ideas relating to order meriting emphasis. Jackson strongly questioned the idea of a global balance of power. Peace and security, he was convinced, "“depend not on a balance of power, but on a certain imbalance of power favourable to the defenders of peace - in which the strength of the peace keeper is greater than that of the peace upsetter"' (emphasis added) (cited in Kaufman, 2000: 139). It was from this premise that Jackson evaluated successive American foreign and defence policies. It was also the premise underlying the 1992 Defense Planning Guidance and 1993 Regional Defense Strategy, a premise which assumed stability was a product not of a carefully constructed global balance of power, but of the presence of a militarily preponderant power capable of stymieing the ambitions of regional and global aggressors.

Writers for Commentary lent their support to Jackson, strongly questioning the belief that stability was best maintained in a bipolar or multipolar world. A world in which power was concentrated in the hands of a preponderant America would be, according to these writers, more stable than the bipolar and multipolar alternatives. "Was it really true," asked Theodore Draper, "that the danger of war arises if one nation becomes infinitely more powerful than others?" (Draper, 1974: 29). "One had imagined," he replied to those such as Nixon who subscribed to this view, "that the danger increased as the gap closed" (Draper, 1974: 29). Podhoretz, in a similar vein, questioned the opening to China, fearing that America would "rely on the China card as an excuse for failing to build up our own power" (Podhoretz, 1980a: 39). The force of these ideas inexorably leads to the conclusion that America should not

\footnotetext{
${ }^{132}$ For an overview of five specific critiques Jackson levelled at détente, see Kaufman, 2000: 248-252.
} 
participate in a balance of power system. "China," after all, was said to be "so weak that its contribution to the containment of Soviet imperialism may be negligible" (Podhoretz, 1980a: 39). That there were several neoconservatives throughout the Cold War propounding these arguments is indicative of their faith in American power and evidence of an incipient faith in a unipolar international order. It is evidence, in other words, that neoconservatives envisioned a world in which a balance of power system could and should be transcended.

Yet it was also the ideas embedded in neoconservative critiques of détente, and its various elements, which laid the groundwork for the arguments made following the end of the Cold War. Neoconservative objections to the "Nixon Doctrine," for instance, reveal the degree to which neoconservatives objected to the idea that other international actors could be relied upon to contribute to international order. The doctrine, first articulated on the island of Guam in 1969, maintained that although regional powers with which America had security ties would not be abandoned, neither would they be permitted to dwell in perpetuity under the American protective umbrella without incurring some of the cost for their own defence. ${ }^{133}$ Nixon, writing an article for Foreign Affairs in 1968 before his electoral triumph of that year, expounded the logic behind what Robert Litwak labelled "regional devolution" and "superpower détente" (Litwak, 1984: 91). Each of these policies, if successfully implemented, according to Litwak, would "serve as the instrumentality of the other" (Litwak, 1984: 91). By encouraging regional powers to assume greater responsibility for their own security, the likelihood of superpower confrontation on the periphery would be reduced, thus facilitating a more stable and enduring détente between the superpowers. Nixon put it thus:

If another world war is to be prevented, every step possible must be taken to avert direct confrontations between the nuclear powers. To achieve this, it is essential to minimize the number of occasions on which the great powers have to decide whether or not to commit their forces. These choices cannot be eliminated, but they can be reduced by the development of regional defense pacts, in which nations undertake, among themselves, to attempt to contain aggression in their own areas (Nixon, 1967/1968).

\footnotetext{
${ }^{133}$ For a thoughtful discussion on the Nixon Doctrine, the historical context in which the doctrine was articulated, and some of its problematic implications, See Kimball, 2006.
} 
It was, according to Nixon, neither desirable nor possible to expect regional powers to remain dependent on America for their security. Speaking of a growing Japan, Nixon explained, "Looking toward the future, one must recognise that it simply is not realistic to expect a nation moving into the first rank of major powers to be totally dependent for its own security on another nation, however close the ties" (Nixon, 1967/1968). Indiscriminate commitments would, he feared, overtax American resolve and increase the likelihood of superpower entanglement on the periphery, thus threatening to bring the superpowers into direct confrontation. The two policies implemented to contend with domestic lethargy and the prospects of great power war - détente and regional devolution - were linked, and both were very much guided by considerations of a global balance of power and the maintenance of a stable equilibrium. As Robert Litwak argued, "the Nixon Doctrine, and the strategy of politico-military retrenchment that it implied, was to permit the administration to engage in the kind of diplomacy of manoeuvre and manipulation made necessary by a world of nascent multipolarity" (Litwak, 1984: 124).

The concerns neoconservative intellectuals expressed in relation to the Nixon Doctrine bespoke their doubts as to whether there was any reliable substitute for American power. There was, in their commentary, no viable alternative to a world in which American power served as the sole bulwark against the breakdown of order and the ambitions of aggressive regimes. The most pungent critique came, once again, from Norman Podhoretz. Before turning his attention to the Nixon Doctrine, Podhoretz had described Kissinger as someone "who often sounds like Churchill and just as often acts like Chamberlain" (Podhoretz, 1976: 35). If an isolationist was considered to be one who advocated that America should refrain "from the use of force to prevent the spread of Communism anywhere in the world except the United States," then it was "by no means absurd," according to Podhoretz, "to see Henry Kissinger as an isolationist" (Podhoretz, 1976: 37). Such a statement, however, may reveal more about the degree of global activism Podhoretz supported than it does about the actual content of the policies pursued by the Nixon-Kissinger administration. Describing Kissinger as an "isolationist" who would do nothing to prevent the coming to power of a communist government is highly questionable. One 
suspects that the people of Vietnam and Chile would not see Nixon and Kissinger as the isolationists Podhoretz does. ${ }^{134}$

The Nixon Doctrine, however, was just another example, Podhoretz argued, of the administration's isolationism. The doctrine, he explained, "rested on the highly questionable assumption that the Soviet Union could be contained by any force other than American power" (Podhoretz, 1980a: 32). When the Nixon-Kissinger administration reached out to China in order to balance the Soviet Union, it was interpreted by Podhoretz as a logical implication of the Nixon Doctrine, an example of America once again relying on "local surrogates" instead of "its own military power to deter or contain Soviet-sponsored aggression" (Podhoretz, 1980a: 32). The fall of South Vietnam in 1975 and the fall of the Shah in 1979 confirmed Podhoretz's belief that America's regional surrogates were incapable of checking the expansion of communist movements and defending American interests. "In the case of Vietnam," he argued,

not only was the surrogate power unable to hold the line on its own, but in the event, the United States refused even to provide it with the promised aid to defend itself against a military invasion encouraged and supplied with the massive quantities of Soviet arms (Podhoretz, 1980a: 32).

The Nixon Doctrine, according to Podhoretz, amounted to little more than an abject surrender to the Soviet Union. Did it mean, he asked, "that even Western Europe and Japan would be left to their own devices?" (Podhoretz, 1976: 36) Fearing it did, Podhoretz gloomily predicted,

it follows that we can no longer afford to extend protection even to Western Europe and Japan, whose survival as free societies may, in this conception of the world, still be desirable but can no longer be considered a vital American interest" (Podhoretz, 1976: 36).

Podhoretz provides little evidence that Nixon and Kissinger were prepared to write off Western Europe and Japan. In fact, it is a proposition many Cold War

\footnotetext{
${ }^{134}$ For a useful examination of the Nixon-Kissinger administration's involvement in Chile following the 1970 election of President Salvador Allende, see Kinzer, 2006: Ch. 8; and Weiner, 2007: Ch. 29.
} 
scholars, to say nothing of Kissinger himself, would strongly contest. "Ideological differences with existing communist powers would not be allowed to stand in the way of alignments dictated by balance of power considerations," argues John Lewis Gaddis, "but the administration was not prepared to tolerate further victories for communism" (emphasis added) (Gaddis, 2005: 286). The Nixon-Kissinger administration, in other words, was never prepared to write off Western Europe or Japan. ${ }^{135}$ The administration saddled America with the responsibility for holding the global balance of power. Their neoconservative critics equated such a role with appeasement and isolationism. Even today, it is not uncommon to hear neoconservatives echo Podhoretz's critique. Paul Wolfowitz, for instance, questioned the value of the opening to China, arguing that China was in greater need of America than America was of China. ${ }^{136}$ The conclusion to which this idea would lead, namely, that America stood in no need of others to achieve its foreign policy objectives, would be a hallmark of post-Cold War neoconservatism.

This is not to suggest that there is no ground for questioning the opening to China in the early 1970s or strongly contesting aspects of the Nixon-Kissinger approach to American foreign policy. But it is to suggest that Podhoretz's critique of the Nixon Doctrine and Wolfowitz's scepticism about the value of the opening to China reflects the degree to which the idea of a global balance of power is uncongenial to neoconservatives. The Nixon-Kissinger administration saw a complex multipolar world, a world in which differing elements of power were widely diffused throughout the international system, but they never questioned the idea of a global balance of power, or abandoned America's policy of containment. Under the Nixon-Kissinger administration, America, in the words of William Wohlforth, was groomed to become "the central balancer in a complex balance of power" (Wohlforth, 1993: 215). To equate such a role with isolationism or an overly solicitous attempt to find a substitute for American power is a caricature. As Hans Morgenthau put it,

\footnotetext{
${ }^{135}$ It was not even prepared to write off Chile let alone two of the most important centres of industrialmilitary power!

${ }^{136}$ For a second hand account of Wolfowitz's views, see Mann, 2004: 114. Wolfowitz himself, though, is quite candid about this. He argues, "It is a mystery why the United States needed China's help to reach two Strategic Arms Limitation Agreements that conceded large advantages to the Soviet Union. It is much more obvious what China gained from having a relationship with a nuclear superpower during a period when the Soviet Union was threatening preventive war against China and massively building up its military forces in the Far East" (Wolfowitz, 2000: 328).
} 
The holder of the balance occupies the key position in the balance-of-power system, since its position determines the outcome of struggle for power. It has, therefore, been called the "arbiter" of the system, deciding who will win and who will lose. By making it impossible for any nation or combination of nations to gain predominance over the others, it preserves its own independence as well the independence of all the other nations, and is thus a most powerful factor in international politics (Morgenthau, 1993: 210).

When Kissinger wrote that "Nixon took perhaps the most daring step of his presidency by warning the Soviet Union that the United States would not remain indifferent if it were to attack China," he in effect signalled America's intentions to act as the "arbiter" of the distribution of power in the international system (Kissinger, 1994: 723). Whatever one may think of such a strategy, it certainly cannot be said that it bespoke an eagerness or willingness to preside over an American withdrawal from the world.

\section{The Perils of Multipolarity}

At the end of the Cold War, most neoconservatives recognised that there was no messianic global superpower capable of menacing America, at least in the short-term. Some, to be sure, emphasised the threat posed by China, occasionally presenting China in much the same way as Podhoretz presented the Soviet Union. ${ }^{137}$ This time, however, the threat justifying the perpetuation of American military preponderance was said to inhere more in the structure of the anarchical international system. Their unease with the idea of a global balance of power, in other words, was no longer rooted in the fear of a clearly definable global adversary wedded to an antithetical ideology, but in the fear of a particular distribution of power in the international system thought to imperil stability. These concerns were sporadically expressed, I showed, throughout the Nixon-Kissinger era of détente, but following the demise of the Soviet Union, they became de rigueur.

\footnotetext{
${ }^{137}$ Kagan produced several tersely written articles for the Weekly Standard throughout the 1990s which called on American policy-makers, especially those in the Clinton administration, to abandon their illusions regarding China, end their policy of engagement, and stand up for democratic Taiwan. See Kagan \& Kristol, 1999; and Kagan, 1999a; 1999b; 1999c; and 2000.
} 
Having attained the "imbalance of power" to which Jackson referred, neoconservatives continued to emphasise the importance of perpetuating American military preponderance in the post-Cold War world. The danger, they argued, was that America would relinquish its position of ascendency and embrace a multipolar world. Paul Wolfowitz, serving as President George W. Bush's first term Deputy Secretary of Defense, was arguably the most influential exponent of the neoconservative variant of hegemonic stability theory. The theory, in its simplest formulation, according to one IR theorist, assumes "that the presence of a single, strongly dominant actor in international politics leads to collectively desirable outcomes for all states in the international system" (Snidal, 1985: 579). To this day, it is a thesis finding willing and capable adherents among scholars of international politics (see Mandelbaum, 2006). Neoconservatives, of course, are not aiming to develop sophisticated or coherent theories of international politics, although, one should note, the strategic thought shaping their support for unipolarity appears to have extracted key ideas from IR scholarship.

The documents released throughout the concluding days of the first Bush administration provide considerable insights into the strategic thought underlying neoconservative support for a unipolar international order. Serving in a lower tier of the Defense Department in the first Bush administration, Wolfowitz oversaw the writing of the 1992 Defense Planning Guidance (DPG), the aforementioned document which sparked a lively debate relating to its claim that America should block the emergence of a global peer competitor. Wolfowitz is said to have delegated the task of writing the document to Lewis 'Scooter' Libby who himself delegated the task to Zalmay Khalilzad. ${ }^{138}$ After a copy of the document was leaked to The New York Times, causing a considerable furore, Wolfowitz distanced himself from the draft, insisting that he had not seen it. He did state, however, that the 1993 Regional Defense Strategy (RDS), a more diplomatic and less inflammatory publication released in the wake of the controversy surrounding the 1992 DPG, received his close attention and approval. He explained, "What is published, while I admit some of the corners are rounded off on it, reflects my views" (Wolfowitz, 2003). This is a significant admission, for it suggests that Wolfowitz not only agreed with the contents

\footnotetext{
${ }^{138}$ For a discussion on the details relating to the writing and premature release of the Defense Planning Guidance, see Mann, 2004: 208-215; Packer, 2005: 12-15; and Solomon, 2007: 50-54.
} 
of the 1993 RDS, but that the document's more diplomatic tone veiled firmer convictions about its strategic assumptions.

One such assumption was that America must prevent a return to a world in which multiple poles of power exist. The Nixonian assumption that great power war was a product of a world in which one state strove for global hegemony, eschewing a multipolar world, was rejected with as much dogmatic élan by neoconservatives writing in the post-Cold War era as it was by neoconservative cold warriors. Neoconservatives, in fact, identified multipolarity as a precipitant of uncontrollable security dilemmas - the tendency among states, fuelled by mutual suspicions about the intentions of others, to match the military build ups of rival states by engaging in an endless arms race. In other words, they turned the Nixonian assumption on its head, ascribing the idea of a global balance of power with responsibility for a litany of offences, including global instability, tense arms races, and great power war. As the authors of the 1993 RDS put it,

It is not in our interest or those of the other democracies to return to earlier periods in which multiple military powers balanced one against another in what passed for security structures, while regional, or even global peace hung in the balance. As in the past, such struggles might eventually force the United States at much higher cost to protect its interests and counter the potential development of a new global threat (RDS, 1993: 7).

Implicit in most of these observations is a set of assumptions, shared not only by neoconservatives, derived from a particular interpretation of the twentieth century's global conflicts. "Adherents of the theory of the security dilemma," argues Michael Lind, "explain the world wars and the Cold War as the tragic and unintended results of defensive strategies of great powers that drifted into conflict more on accident than purpose" (Lind, 2006: 156). It is for this reason that those who drafted the aforementioned documents emphasise the importance of preventing the emergence of a multipolar world from which "the spread of disorder and a possible return to conditions similar to those of the first half of the twentieth century" would endanger the stability of the international system (Khalilzad, 1995). "The balance of power system failed in the past," argued Zalmay Khalilzad, the original author of the 1992 DPG, "producing World War I and other major conflicts. It might not work any 
better in the future - and war among major powers in the nuclear age is likely to be more devastating" (Khalilzad, 1995).

It is somewhat debatable, however, as to whether the global conflicts of the twentieth century should be attributed so heavily to a multipolar distribution of power which compels states to allay their fears through an endless cycle of arms build ups. Michael Lind, author of The American Way of Strategy (2006), a thoughtful appraisal of how American policy-makers have attempted to reconcile national security strategies with the American way of life, strongly questions this logic. Echoing some of the claims made by World War One historians such as Fritz Fischer ${ }^{139}$ and Cold War historians such as Wilson Miscamble, ${ }^{140}$ Lind argues that the global conflicts of the twentieth century "were crimes - premeditated crimes. And they arose, not from the dynamics of the international system, but from the ambitions of aggressive regimes in Berlin and Moscow" (Lind, 2006: 156). Neoconservatives, though, attribute the outbreak of the two world wars to a different source - uncontrollable security dilemmas engendered by the absence of a hegemonic power. "Collective security failed in the 1930s," explained the RDS, "because no strong power was willing to provide the leadership behind which less powerful countries could rally against Fascism" (RDS, 1993: 8).

If one is to develop an appreciation for the competing grand strategies between the neoconservative unipolarists and Kissingerian balance of power multipolarists, then their competing interpretations of the origins of the twentieth century's world wars must be understood, especially World War One. Neoconservatives attributed the outbreak of the Great War to the dynamics of the international system, or, more precisely, to a particular configuration of power in the international system multipolarity. In Diplomacy (1994), a massive volume dissecting the deeds of some of history's master practitioners of the diplomatic craft, Kissinger locates the roots of the conflict deep in nineteenth century European statecraft, emphasising the fear engendered by Russian expansionism and the lack of subtlety characterising

\footnotetext{
${ }^{139}$ Fischer's study on the First World War, in many ways, remains a benchmark against which all subsequent historical analyses must contend. He attributes the outbreak of the conflict to Germany's regional and global ambitions and its quest to become a global superpower. See Fischer, 1967. For a more recent analysis of the origins of the First World War which generally reinforces Fischer's conclusions, and also draws out some of the implications for IR theory, see Lieber, 2007.

${ }^{140}$ Miscamble provides a critical appraisal of the Truman administration's attempt to continue along the same path as President Roosevelt and forge a working relationship with Stalin. See Miscamble, 2007. For an older yet no less valid study that attributes the outbreak of the Cold War to Stalin's expansionist designs, see Schlesinger, 1967-68.
} 
Germany's foreign policy following the departure of Bismarck in 1890. For "the nearly twenty years that Bismarck led Germany," Kissinger claimed, "he practiced the Realpolitik he had preached with such moderation and subtlety that the balance of power never broke down" (Kissinger, 1994: 146). To keep Russia and Austria from colliding in the Balkans, Kissinger explained,

Bismarck's diplomacy had produced a series of interlocking alliances, partially overlapping and partially competitive which ensured Austria against Russian attack, Russia against Austrian adventurism, and Germany against encirclement, and which drew England into resisting Russian expansion toward the Mediterranean (Kissinger, 1994: 160).

According to Kissinger, Bismarck's successors could not navigate their way through the very complex set of arrangements and alliances he forged, "partly," he explains, "because his contemporaries had such difficulty comprehending their increasingly convoluted nature" (Kissinger, 1994: 166). Regardless of whether it was the territorial dispute with France over Alsace Lorraine, the failure to renew the Reinsurance Treaty with Russia, the rigid alliance with Austria-Hungary, or the decision to challenge British naval supremacy by launching a massive naval build up, Germany was said to have alienated the predominant European powers. Unlike his successors, Bismarck was said to have shrewdly manipulated the European balance of power, reassuring regional powers of Germany's benign intentions and forging a number of alliances which reduced the likelihood of hostilities breaking out in the Balkans. Bismarck, in other words, knew the limits of his nation. "For all the complexity of his manoeuvres," Kissinger explains,

Bismarck had never attempted to go beyond the traditions of the balance of power. His successors, however, were clearly not comfortable with the balance of power, and never seemed to understand that, the more they magnified their own strength, the more they would encourage the compensating coalitions and arms build-ups inherent in the system of European equilibrium (Kissinger, 1994: 171-172).

Kissinger, in other words, attributed the outbreak of World War One not to the workings of the balance of power, as do many neoconservatives, but to the 
repudiation of balance of power logic. In 1894, after France and Russia had reached what amounted to a diplomatic and military alliance, it was, as Kissinger put it, "the beginning of the end for the operation of the balance of power" (Kissinger, 1994:181182). Rigid alliances had been formed as the Triple Entente and the Triple Alliance bound themselves to ungovernable Balkan allies. "By the end of the first decade of the twentieth century," Kissinger argues, "the balance of power had degenerated into hostile coalitions whose rigidity was matched by the reckless disregard for consequence with which they had been assembled" (Kissinger, 1994: 194).

This violated one of Kissinger's cardinal principles which guaranteed a stable balance of power. In order for such a system to endure, "each nation," according to Kissinger, "must feel itself free to align with any other state, depending on the circumstances of the moment" (Kissinger, 1994: 182). For Kissinger, the key word is "flexibility," something he describes as "the mainspring of Realpolitik" (Kissinger, 1994: 166). Without a set of shared values tying the continental powers together and absent the flexibility to switch alliance partners as interests dictated, the balance of power was bound to collapse, leading to the Great War.

What, then, are the implications of these competing interpretations of the origins of the First World War? For Kissinger, the implications can be seen in much of the foreign policy he pursued as National Security Adviser and Secretary of State, especially the opening to China. In the Nixon-Kissinger years, America would not permit its ideological commitment to liberal democracy to becloud its recognition of opportunities to manipulate the global balance of power. For neoconservatives, the strategic logic underlying the DPG and RDS assumed that Bismarckian balance of power realpolitik led to the outbreak of the First World War. As such, only overwhelming American power, they believe, can be trusted to prevent a return to global disorder. "If America wants stability," Charles Krauthammer declared, "it will have to create it" (Krauthammer, 1990-91).

Global institutions such as the United Nations certainly could not be relied upon, for it was said to be the "guarantor of nothing" (Krauthammer, 1990-1991). "We are in for abnormal times," Krauthammer presciently forecast at the end of the Cold War (Krauthammer, 1990-91). "Our best hope for safety in such times, as in difficult times past," he concluded, "is in American strength and will - the strength and will to lead a unipolar world, unashamedly laying down the rules of world order and being prepared to enforce them" (Krauthammer, 1990-91). 
This was an argument propounded relentlessly by neoconservatives throughout the 1990s. American preponderance, Kristol and Kagan declared in their 1996 article for Foreign Affairs, "is the only reliable defense against a breakdown of peace and international order" (Kristol \& Kagan, 1996). In order to preserve America's preponderant position in the international system, Kristol and Kagan recommended that America spend an additional $\$ 60-\$ 80$ billion dollars a year on defence (Kristol \& Kagan, 1996). In the election year of 2000, the Project for a New American Century released a publication entitled Rebuilding America's Defenses: Strategy, Forces and Resources for a New Century (2000), a publication strongly reinforcing this conclusion. It was endorsed and signed by the likes of William Kristol, Robert and Donald Kagan, Paul Wolfowitz, and Lewis I. Libby. The publication articulated a consistent neoconservative refrain: "If an American peace is to be maintained, and expanded," the publication warned, "it must have an unquestioned foundation on American military pre-eminence" (Rebuilding America’s Defenses, 2000: 4).

The purpose of perpetuating America's military preponderance, Paul Wolfowitz explains, is "to dissuade countries from pursuing dangerous capabilities in the first place, by developing and deploying U.S. capabilities that reduce their incentives to compete" (Wolfowitz, 2001a/2004: 28). Only when America had reached a stage of unmatched preponderance, it was believed, could the world be inoculated against a global cataclysm reminiscent of the one which befell Europe in 1914. Although it has been over ninety years since the guns fell silent in Europe, providing what turned out to be a temporary respite from great power war, the interpretations of the origins of this conflict have decisively shaped the way in which American policy-makers think about America's role in the world. If ever there was an instance of ideas and beliefs having consequences for a nation's grand strategy, this must surely qualify as one of the most significant and understated.

\section{$\underline{\text { America as the Great Pacifier }}$}

Coupled with that of preserving American military preponderance and preventing the emergence of a global competitor, neoconservatives emphasise the importance of stationing significant quantities of American troops on European and Asian soil. This policy, irrespective of whether one agrees or disagrees with it, is often described by commentators and scholars as a policy of "reassurance" or "pacification" (see Lieber, 
2005: Ch. 6; Lind, 2006: 161; Mandelbaum, 2005: 31-41). "During the Cold War, the United States deployed major military forces in Europe and East Asia," Michael Mandelbaum explains, "the two regions where World War Two II had been chiefly fought and where, Americans believed, without the presence of those forces, yet another bloody, destructive conflict would erupt" (Mandelbaum, 2005: 31). The presence, and the willingness to offer security guarantees, adds Robert Art, "assures Germany's neighbours that Germany will not return to its ugly past; in East Asia, it reassures Japan's neighbours about Japan and China's neighbours about China" (Art, 2003: 58). The need for such a presence, moreover, is often considered to inhere in the structure of the international system. Explains Mandelbaum,

Reassurance ensures against what might happen, and the need for it arises from the structure of the system of sovereign states. Because no superior power controls relations among them, an attack by one against another is always possible. Governments therefore tend to take steps to prepare to defend themselves. In foreign policy, wariness, suspicion, and preventive measures are the norm. But military preparations that one country undertakes for purely defensive reasons can appear threatening to others, which may then take military measures of their own and so set in motion a spiral of mistrust and military buildups (Mandelbaum, 2005: 34).

Neoconservatives strongly defend the American presence in Europe and Asia, presenting it as a fundamental pillar of international stability averting the "spiral of mistrust and military build ups" to which Mandelbaum refers. This is not, of course, an unreasonable argument, for few could dispute that America's regional presence in Europe and Asia has dampened latent regional tensions. To make this argument today, however, reflects more than a profound pessimism about the prospects of great power cooperation, especially in Europe; it is evidence of the extreme conclusions to which a mindset so alarmed by the prospects of the emergence of a multipolar world can lead. Exemplified by several neoconservatives who spent the 1990s recycling arguments similar to those of Wolfowitz and Khalilzad in op-ed pieces written for newspapers such as the Washington Post and journals such as Foreign Affairs and Foreign Policy, neoconservatives drew attention to the "threat" posed not only by Russia and China, but democratic Germany. The alternative to an American presence 
in Europe, predicted Charles Krauthammer, was "a nuclear Germany dominating Europe" (cited in Mann, 2004: 211). Despite occasional public pronouncements of European leaders calling for a return to a multipolar world, Robert Kagan questioned whether European nations were truly ready to assume the responsibilities that would attend a multipolar world. He was nonetheless quick to describe the dangers if European nations proved otherwise:

Genuine multipolarity would inevitably mean a return to the complex of strategic issues that plagued the world before World War II: in Asia, the competition for regional pre-eminence among China, Japan, and Russia; in Europe, the competition among France, Germany, Great Britain, and Russia (Kagan, 1998b).

The above passages, it should be noted, could just as easily have been extracted from John Mearsheimer's The Tragedy of Great Power Politics (2003), a book replete with pessimistic prognostications about the prospects of great power cooperation. The passage suggests not that states in Europe are without the "capacity" or "will" to assume greater responsibility for their own security, for this is a different question, one which has been addressed by thoughtful sceptics such as Robert Lieber and hopeful optimists such as Charles Kupchan; ${ }^{141}$ the passage implies that Europe should be prevented from doing as much. It would be a mistake to read Kagan's Of Paradise and Power: America and Europe in the New World Order (2003) and conclude Kagan's Europe is a pusillanimous continent incapable of contemplating the use of force. Europe's "Kantian world of perpetual peace," to borrow Kagan's description, was a world said to be created only by the "presence of American military forces on European soil” (Kagan, 2003: 73). If this presence were to disappear, Kagan explained elsewhere, "the old European questions - chiefly, what to do about Germany, would quickly rear their hoary heads" (Kagan, 1998b).

Why, though, one could ask, would concern about Germany be as pronounced at the time Kagan was writing as it was at the height of the Cold War? If one believes democratic nations to be more pacific, as Kagan does, why would German power be considered as threatening in the late 1990s as it was when memories of the two world

\footnotetext{
${ }^{141}$ For a critical assessment of evidence which suggests that Europe is emerging as a pole of power independent of the U.S, see Lieber, 2005: Ch. 3. For an argument which states that Europe is emerging as an independent pole of power capable of balancing the U.S., see Kupchan, 2002: Ch. 4.
} 
wars launched by that country were fresh in the minds of American and European policy-makers, not to mention the minds of American and European publics? Has German political culture not undergone a transformation since the first half of the twentieth century? Even Daniel Goldhagen, author of Hitler's Willing Executioners (1997), a persuasive indictment of the complicity of ordinary Germans in the Nazi holocaust, argued, "Political cultures evolve and change, as has German political culture during the Federal Republic" (Goldhagen, 1997: 478). The strategic logic equating stability with the maintenance of overwhelming American military superiority and a policy of regional reassurance - or, in Michael Lind's words, a willingness to "volunteer to fight not only America's wars on America's behalf, but also Japan's wars on Japan's behalf, Germany's wars on Germany's behalf, China's wars on China's behalf, and so on" - rests on the premise that great power war is as much a product of a world in which multiple poles of power exist as it is the character of irredeemably aggressive regimes (Lind, 2006: 161).

The idea that Europe must be kept weak in order for America to be kept strong would be alien to many of those who served in America's foreign policy establishment in the aftermath of World War Two. Some of the greatest challenges and sources of transatlantic friction throughout the course of the Cold War, in fact, centred upon decisions relating to Germany, its reconstruction, its rearmament, and its eventual reunification. At each stage, Germany's neighbours, especially France, looked askance at America's attempts to allow a measure of autonomy for their former adversary. The goal, to be sure, was to integrate "Germany's western zones within a web of transatlantic institutions spun under American leadership," but policymakers such as Dean Acheson, President Truman's second term Secretary of State, regularly pushed the envelope on German rearmament, especially after the Korean War (see Beisner, 2006: $135 \&$ Ch. 21). If America was to resist the expansion of communism, it was necessary, so the thinking ran, for the Federal Republic of Germany and Western Europe to develop strong, preferably integrated, conventional forces capable of deterring the Soviet Union from taking advantage of American involvement in other regions (see Leffler, 1992: 384-385). America could not, according to these thinkers, be the sole guarantor of order in the world, for there was an expectation that Europe would have a role to play in its own defence and in the preservation of the global balance of power. 
As for Krauthammer's concern about "a nuclear Germany dominating Europe," nothing could be less likely. Germany has shown no inclination to develop its own nuclear weapons capability since the end of the Cold War, preferring to rely on NATO and greater European integration as the means through which its security can be assured. Jenifer Mackby and Walter Slocombe, two scholars who have examined the history of the debates relating to Germany's non-acquisition of nuclear weapons, argue, "The German experience presents perhaps the clearest case of nuclear weapons renunciation becoming a permanent policy" (Mackby \& Slocombe, 2004: 209). Germany's reliance on NATO assures that it does not need nuclear weapons, and there is little, if any, evidence which suggests that NATO is set to be dismantled. Notwithstanding the wishes of the odd IR theorist, ${ }^{142}$ debates in the United States centre not upon NATO dismantlement, but upon NATO enlargement. Yet even if NATO did disappear, it is still somewhat contestable as to whether German political elites and German public opinion would sanction the acquisition of nuclear weapons. As Mackby and Slocombe put it, "If, somehow, confidence in NATO should falter, Germany would have the option of relying on common European defenses - likely EU based - that would include the nuclear forces of Britain and France" (Mackby \& Slocombe, 2004: 211).

To have spoken of Germany as if it should still inspire a degree of fear similar to that to which it inspired throughout the Cold War and before, as neoconservatives have, is to speak as though the strategic environment has not undergone any transformation in the past fifty years. "Germany's resources and ambition," Charles Kupchan rightly argues, "have been merged with the resources and ambition of Europe and the enterprise of European integration" (Kupchan, 2003: 124). Yet it was not so much Germany, it should be noted, that inspired neoconservative fears as it was global multipolarity. The fanciful concerns expressed in relation to Germany emerged not from any detached analysis of that country, but from a fear of a particular distribution of power in the international system. It emerged, in short, from a particular set of beliefs about the causes of great power war.

Neoconservatives reject the idea of a global balance of power, believing that America can and should assume responsibility for preserving order itself. There is, I

\footnotetext{
${ }^{142}$ Writing in The Peace of Illusions (2006b), Christopher Layne advocates a strategy of off-shore balancing, claiming, "As an offshore balancer, the United States would leave NATO and retract its military power from Europe" (Layne, 2006b: 187).
} 
explain below, even greater evidence reinforcing this argument. Neoconservatives are more than prepared to see America act alone in the world, but they do not expect America to have to act alone in the world. Once the world witnesses a bold display of hegemonic leadership, other states in the international system, neoconservatives believe, will hastily align themselves with the American hegemon. If one was to put it in terms of IR theory, neoconservatives assume that America's allies will bandwagon, not balance.

\section{Neocons, Alliances, and Bandwagoning and Balancing}

The neoconservative rejection of balance of power logic is evidenced not only by their explicit questioning of it, but by their assumption that states will respond to vigorous displays of international leadership by bandwagoning with the American hegemon. They do not conceive of a world in which American power could be balanced, certainly not by America's allies. "In the end," the authors of the RDS argued, "there is no contradiction between U.S. leadership and multilateral action; history shows precisely that U.S. leadership is the necessary prerequisite for effective international action" (RDS, 1993: 8). Once America had committed itself to a course of action, in other words, other powers could be expected to bandwagon with the preponderant power. This was an argument asserted not only by the authors of the RDS, but by several neoconservative intellectuals. "When George Bush senior said of the invasion of Kuwait, "this will not stand," Charles Krauthammer argues, "and made it clear that he was prepared to act alone if necessary, that declaration - and the credibility of American determination to act unilaterally - in and of itself created a coalition" (Krauthammer, 2002/2003: 6).

Those who assume that states will automatically bandwagon with a preponderant power, according to Stephen Walt, assume that "states are attracted to strength" (Walt, 1987: 20). "The more powerful the state and the more clearly this power is demonstrated," so the thinking goes, "the more likely others are to ally with it" (Walt, 1987: 20). This, according to Walt, is not always an accurate reflection of how nations behave (see Walt, 1987: 148-153). The bandwagoning rationale, he argued, is often invoked by those "seeking to justify overseas involvements or increased military budgets" (Walt, 1987: 19). The rationale, and the argument made by Krauthammer, also omits any distinction between the greater likelihood of persuading others to 
support an intervention against an aggressor state which has violated agreed upon norms of international society - the principle of non-intervention and state sovereignty, for instance - and the greater difficulty of persuading others to support an intervention in defence of principles - preventive war, for instance - which have a much more tenuous foundation in international law. One should see a palpable difference between the principles for which the war in 1991 to evict Saddam from Kuwait was waged to the principles for which the war in 2003 to depose Saddam was waged.

Arguments by neoconservatives that assume other states will simply align themselves with the current hegemon in defence of international principles which are not held in common by other members of the international community have sparked a lively literature analysing what is often described as "soft balancing." "143 Whatever the merits of the arguments made by those engaged in this debate, few scholars have suggested that displays of American resolve automatically attract other powers to bandwagon with a preponderant America, irrespective of their interests or policy preferences. Such an argument, regularly made by neoconservatives, simply cannot be articulated in any compelling way following the 2003 Iraq War and the opposition of European states such as Germany and France. Even if the latter two states did not engage in balancing against America, hard or soft, in the run up to this conflict, there was certainly a considerable degree of "diplomatic friction" 144 which was attributable to conflicting policy preferences and differing assessments of threat.

Not only, however, did additional states such as France and Germany fail to align themselves with America once the decision to remove Saddam Hussein was made, but America tended to lose allies such as Spain once the war had begun. While neoconservatives insist that it is "ridiculous" to define unipolarity as a condition in which America can achieve all its foreign policy objectives, ${ }^{145}$ their assumption that states will always align themselves with a determined and bold America suggests they do occasionally speak as if this is a possibility.

\footnotetext{
${ }^{143}$ For an introduction to those who support the soft balancing thesis, see Pape, 2005b; Paul, 2005; and Walt, 2005: 126-132. For an introduction to the work of those who are critical of the literature and have claimed that additional theorising on soft balancing needs to take place, see Brooks \& Wohlforth, 2005; and Liber \& Alexander, 2005.

${ }^{144}$ This is the argument made by Keir Lieber and Gerard Alexander. Lieber and Alexander insist that scholars must distinguish between soft-balancing and traditional diplomatic friction. See Lieber \& Alexander, 2005: 130-133.

${ }^{145}$ As Krauthammer goes on to put it, "This is a standard not for unipolarity but for divinity" (Krauthammer, 2002-2003.)
} 
Whether the opposition of states such as Germany and France can be described as "soft balancing" or a simple divergence in "policy preferences" is not necessary to resolve here. Opposition can take many forms, some of which will be frustrating but benign, and some of which can pose formidable obstacles to a state's capacity to achieve its foreign policy objectives. There is, moreover, a fundamental semantical point contributing to the neoconservative rejection of the idea of a global balance of power. Neoconservatives argue that America's role in the world should be one of "benevolent global hegemony" (see Kristol \& Kagan, 1996). Yet global hegemony is not possible, for the term implies a degree of potential domination which is unlikely in the current international system. Except "for the unlikely event," argues structural realist John Mearsheimer, "wherein one state achieves clear-cut nuclear superiority, it is virtually impossible for any state to achieve global hegemony" (Mearsheimer, 2003: 41). A unipolar world cannot escape balance of power logic any more than a preponderant power can escape concerns with international legitimacy. "A unipolar world," argues political scientist Robert Pape,

is a balance of power system, not a hegemonic one. Powerful as it may be, a unipolar leader is still not altogether immune to the possibility of balancing by most or all of the second-ranked powers acting in concert. To escape balancing altogether, the leading state in the system would need to be stronger than all second-ranked powers acting as members of a counterbalancing coalition seeking to contain the unipolar leader. The term 'global hegemon' is appropriate for a state that enjoys this further increase in power, because it could act virtually without restraint by any collection of other states anywhere in the world (emphasis added) (Pape, 2005b: 11).

While scholars will persist in arguing about the desirability and durability of a unipolar word, the above argument, it should be noted, is not an argument against American power, or even perpetuating a preponderance of power. American power has always had a role to play in checking the designs of regional and global aggressors. "Aggressors," as Jeane Kirkpatrick succinctly put it, "are a constant in history" (Kirkpatrick, 2007: 272). This, in fact, is a greater justification for perpetuating American military preponderance than the fear of a multipolar distribution of power in the international system. Aggressive leaders who rule 
expansionist regimes are natural risk-takers, irrespective of whether there is a hegemon or latent hegemon in the world. "Perhaps," reflects Warren Kimball when considering the interwar period in the United States, "American military commitments to fight in Europe could have prevented war, though deterrence did not prevent the Japanese from attacking Pearl Harbor" (Kimball, 2003: 26).

In fact, imperial Japan's decision to wage war against America is a perfect example of a regime ruled by an assertive military and a meek civilian leadership which knew that war with America carried great risks, but chose a path consistent with their perception of their nation's national honour. "Destruction with honour," according to Ian Kershaw, one of Britain's most distinguished historians, was considered "better than survival with shame" (Kershaw, 2007: 334). Japan's decision to attack Pearl Harbor was not a result of any configuration of the distribution of power in the international system; it was a consequence of Japan's sense of its exceptionalism, its honour, and its place in the world. ${ }^{146}$

Furthermore, striving for an "imbalance of power" is by no means a radical departure from America's post-World War II foreign policy traditions. In $A$ Preponderance of Power: National Security, the Truman Administration and the Cold War (1992), Melvyn Leffler concluded that the Truman administration, not always wisely in Leffler's view, committed itself to elevating America to a position of unmatched strength and military superiority. "By containing Communist gains and Soviet expansion," Leffler argued, "American officials hoped to perpetuate American preponderance" (Leffler, 1992: 18). The architects of America's Cold War policy of containment were more than aware of the need for American power and more than conversant with the role it could play in thwarting Soviet expansion. Dean Acheson, for instance, "not only wanted the west to contain the Kremlin," argues Robert Beisner, Acheson's most recent biographer. "To win the Cold War, he thought the West must have superior strength" (Beisner, 2006: 126).

In a world of sovereign states and aggressive regimes, it makes sense for America to attempt to perpetuate its military preponderance. Aggressive regimes such as

\footnotetext{
${ }^{146}$ For an elaboration of this argument, see Kershaw, 2007: Ch. 8. It is, furthermore, interesting to note that Robert Kagan frequently speaks of the role honour plays in the behaviour of nations, but does not really draw attention to the fact that nations can act in a way consistent with their perception of honour irrespective of the distribution of power in the international system.
} 
Putin's Russia may indeed be fixtures of the international system. ${ }^{147}$ Kagan's The Return of History and the End of Dreams (2008), a book in which Kagan argues that the era of great power politics and international competition is still very much alive, lacks novelty, but its conclusions are not entirely unsound. It is a sobering, and perhaps necessary reminder, that international politics remains what it always has been: an arena where states can cooperate, but often compete.

The greatest problem with the neoconservative approach to international order, however, is not so much that neoconservatives wish to keep America militarily preponderant, but that they see unsurpassable American strength as being dependent upon all other powers being kept weak. Their ideas, John Ikenberry persuasively argues, lack "a compelling vision for other states - no sense of why they should join this unipolar order or how they fit into it" (Ikenberry, 2004: 18). If America could not attract allies - and most neoconservatives assumed America could - then neoconservatives were still prepared to see America act alone. "You take friends where you find them and when you need them," Krauthammer argued. "But in the end, we decide" (Krauthammer, 2001b). It is unlikely that such arguments facilitate coalition building.

The degree to which neoconservatives publicly deride America's allies and seemingly relish their inferiority to a hegemonic America is without precedent in America's twentieth century foreign relations. Even the Cold War generation of policy-makers for whom neoconservatives regularly express admiration did not entertain visions of a world in which America assumed sole responsibility for preserving international order. Liberal internationalists such as John Ikenberry regularly highlight the way in which this generation of "Wise Men" committed America to work within the set of international institutions constructed after World War Two. "The United States sought to take advantage of the postwar juncture to lock in a set of institutions that would serve its interests well into the future and, in return," Ikenberry argues, "it offered - in most instances quite reluctantly - to restrain and commit itself by operating within an array of postwar economic, political, and security institutions" (Ikenberry, 2004: 164). Even Cold War scholars such as Melvyn Leffler who question the liberal internationalist argument nonetheless find

\footnotetext{
${ }^{147}$ For an excellent analysis of Putin's Russia, an analysis which covers the domestic repression, the foreign policy adventurism, and the intimidation of Eastern Europe, see Lucas, 2008.
} 
themselves identifying points of divergence between the architects of containment and the advocates of assertive unilateralism:

The Wise Men of the Cold War embraced collective security, forged NATO, created a host of other multilateral institutions, and grasped the interdependence of the modern global economy. Nonetheless, they never repudiated the right to act alone. Although they reserved the option to move unilaterally, they did not declare it as a doctrine. They did precisely the opposite. Publicly, they affirmed the U.S. commitment to collective security and multilateralism" (emphasis added). (Leffler, 2004: 23).

By the concluding years of the Bush administration, a large portion of America's foreign policy establishment had accepted that the Bush administration's unilateralism, which was supported enthusiastically by neoconservatives outside the administration, had badly damaged America's reputation abroad. It is perhaps no surprise that studies on anti-Americanism began to proliferate throughout the Bush era, and the era throughout which "neoconservative influence" was considered to have reached its apogee. ${ }^{148}$ Undoubtedly, though, the clearest indication that America's unilateralism was repudiated, or at least softened, was provided throughout the 2008 election campaign. Even John McCain, the unsuccessful Republican nominee, recognised the importance of restoring America's image in the world. "When we believe international action - whether military, economic, or diplomatic - is necessary," he asserted, "we must work to persuade our friends and allies that we are right. And we must be willing to be persuaded by them. To be a good leader, America must be a good ally" (McCain, 2007).

To borrow a Kissingerian term, neoconservatives frequently expressed their hopes that America could transcend a world of "finite possibilities." They have consistently rejected the idea of a global balance of power and invested their faith in the attainment and perpetuation of American military preponderance. Such ideas had their roots in the neoconservative critique of détente. It was throughout this period that neoconservatives began arguing that there was no substitute for American power, certainly not the "regional surrogates" to whom Nixon and Kissinger supposedly

${ }^{148}$ For a massive four volume collection of edited essays on anti-Americanism, see O’Connor, 2007. 
assigned responsibility for their own defence. Whether it was the messianic impulses of an implacable totalitarian adversary or a distribution of power in the international system thought to imperial stability, neoconservatives became wedded to the idea that only unsurpassable American strength can serve as the sole bulwark against the breakdown of international order and stability.

The strategic logic articulated in the 1992 DPG and 1993 RDS would be echoed by many of those who served in the Bush administration, including the President himself. "America has, and intends to keep," President Bush explained in one of his signal foreign policy addresses, "military strengths beyond challenge - thereby, making the destabilizing arms races of other eras pointless, and limiting rivalries to trade and other pursuits of peace" (Bush, 2002/2003: 270-271). America would be kept strong, in other words, and others would be kept weak. That was the only way to a more orderly world.

To insist, though, that America should fear the emergence of independent poles of power, especially in Europe, is to make an argument few figures from America's past would endorse. This is an argument, although made above, worth reiterating. At the 1945 Yalta Summit, Franklin Roosevelt, much to Winston Churchill's consternation, advised Churchill and Stalin that he could not envision American troops being stationed in Europe for any longer than two years. ${ }^{149}$ Even after the Cold War commenced, the Eisenhower administration was willing, at least to a significant degree, to permit European countries to renationalise their security policies, enabling them to become less dependent on the American protective umbrella. ${ }^{150}$ Dean Acheson, a policy-maker Kagan greatly admires, also never believed that America should discourage the emergence of other independent poles of power in the world. ${ }^{151}$ The Truman administration may have had to act in a unilateral fashion on select occasions, but America could not, Acheson knew, resolve all of the world's problems by itself. Order would be the outcome of collective international endeavour, not American unilateralism. "Though ready to act alone," Acheson knew, according to Beisner, "that quarterbacks with blockers won more games than those who scrambled on their own" (Beisner, 2006: 144).

\footnotetext{
${ }^{149}$ For an elaboration on this point, see Beschloss, 2003: 183.

${ }^{150}$ For an excellent historical study which draws attention to President Eisenhower's wish to see American troops brought home from Europe, and his extraordinary willingness to permit America's European allies, including the Federal Republic of Germany, to acquire their own nuclear capability, see Trachtenberg, 1999: Ch. 5.

${ }^{151}$ For Kagan's celebration of Acheson’s legacy, see Kagan, 1998.
} 


\section{Conclusion}

This chapter examined the neoconservative quest to perpetuate America's military preponderance. Neoconservative critiques of détente, I argued, laid the ground work for the unipolarists of the 1990s. Whether it was their critique of the Nixon Doctrine, or their assumption that European powers would automatically revert back to a period of destabilising multipolarity if America lost its position of military preponderance, neoconservative intellectuals and strategic thinkers always arrived at the conclusion that there was no substitute for American power.

The criticisms levelled at neoconservatives throughout this chapter did not amount to an argument for an American withdrawal from the world, or an argument in favour of offshore balancing. Even before the election of Barack Obama in 2008, most of the world, including Europe, wished to work with America, not against. Transatlantic Trends, for instance, an annual survey of public opinion in Europe and America, found that $54 \%$ of citizens within the European Union prefer to tackle problems with America by their side (Transatlantic Trends, 2007: 4). Considering the transatlantic differences throughout the Bush years, this is a high percentage. Whatever America's future role in Europe, and whatever the future of NATO, America should not be concerned about the rise of Europe. Threats, from rogue states with weapons of mass destruction to amorphous terrorists operating across borders to environmental degradation, will continue to proliferate, requiring transatlantic cooperation. And, of course, great power competition is still a part of daily life in the affairs of nations. The possibility of another great power war may not be as great as it once was, but Kagan is right to insist that autocratic regimes must be closely observed. Europe, ideally, should be enlisted as a partner in such an enterprise, not dissuaded from assuming a dominant place in the international system.

Neoconservatives, I concluded, often spoke of the possibility of a world in which America could and should transcend balance of power politics. Given that so many states have a nuclear capability in the current international system, such an argument assumes that America can attain the unattainable. Yet, as I argue in the following chapter, this is part of the logic which underpinned neoconservative support for the idea of preventive war, an idea shaped by the assumption that America must transcend the asymmetrical balancing that rogue states often engage in. Global hegemony implies a degree of potential domination that is not possible in a nuclear world. 
Coupled with their faith in America's capacity to transcend a balance of power international system, neoconservatives argue that all that is needed in order to attract allies is a bold display of national will and resolve. They assume that states will automatically subordinate their interests to those of the preponderant power. Whether this assumption will outlive the 2003 Iraq War is highly unlikely. As an intellectual community disdainful of utopian meliorism, one could argue that many of these assumptions themselves reflect a questionable understanding of the behaviour of nations. In fact, one could argue with a fair degree of validity that it is as if, to misappropriate Walter Laqueur's words, neoconservatives live in a "world in which anything is possible, and anything can be said." 


\section{$\underline{\text { Chapter } 6}$}

\section{$\underline{\text { American Power and Preventive War }}$}

Neoconservatives seek not only to perpetuate American preponderance to preserve global stability and prevent the outbreak of great power war; they aim to employ American power to serve a number of strategic ends. Any study on the neoconservative approach to American foreign policy must come to terms with neoconservative ideas and beliefs on American power. This chapter begins by analysing how neoconservatives attempted to restore the national faith in America's military might in the wake of the Vietnam War. It also examines how they attempted to enhance the effectiveness of American power. The attempt to re-moralise American power and the attempt to capitalise on advances made in sophisticated military technologies, I argue, was an attempt to make the exercise of American power more acceptable, even desirable.

Overwhelming faith in American power, I argue, has fostered among neoconservatives a quixotic confidence in what American power can achieve in the world. It was a confidence on display in Iraq, a conflict I examine comprehensively in this chapter, and it was a confidence leading neoconservatives to embrace the idea of preventive war. It is crucial, I explain, to distinguish between the idea of preemption and the idea of prevention, something neoconservatives rarely do. The idea of preventive war, even after Iraq, has never been repudiated by neoconservatives or even refined so as limits could be imposed upon it.

After the unanticipated consequences of the 2003 Iraq War, neoconservatives remain just as confident that American power is intrinsically benign, and just as certain that American power can achieve a number of strategic objectives. If ever there was evidence that once an idea is embraced it acquires a life of its own, then the idea of preventive war is certainly it. It is an idea, I argue, which permits American soldiers to be deployed abroad in a variety of theatres, fighting a number of battles against a number of different enemies, at a cost which is unendurable. Before that argument is made, though, it is important to return to the conflict that did so much to undermine the image of a noble America: the conflict in Vietnam. 


\section{Podhoretz Revisits Vietnam}

All wars produce their own lessons, but few wars yield a consensus as to what those lessons should be. So it is with Vietnam. In his mea culpa for his own complicity in escalating the war, Robert McNamara, America's then-Secretary of Defense, arrived at a simple and arguably belated conclusion: "We do not have the God given right," he acknowledged, "to shape every nation in our own image or as we choose" (McNamara, 1996: 323). Other Congressional critics such as William Fulbright, thenchairman of the Senate Foreign Relations Committee, spoke of a growing "arrogance of power." “America," Fulbright wrote in 1966, "is now at that historical point at which a great nation is in danger of losing its perspective on what exactly is within the realm of its power and what is beyond it" (Fulbright, 1966: 3).

Public officials such as McNamara and Fulbright, of course, were not the only ones to diagnose what had gone wrong in Vietnam. Journalist David Halberstam authored The Best and the Brightest (1992), the classic study tracing America's creeping involvement in Vietnam. Although Halberstam cited a number of factors propelling America into the war, he emphasised a common theme, namely, "that the capacity to control a policy involving the military is greatest before the policy is initiated but once started, no matter how small the initial step, a policy has a life and a thrust of its own, it is an organic thing" (Halberstam, 1992: 209).

Whatever the merits of these lessons, they were not the lessons neoconservatives derived from the Vietnam War. In fact, neoconservatives understood the consequences of this war as well as anybody, and they were consequences they deeply regretted. In Virtue and Power: the Persistent Moral Dilemma of U.S. Foreign Policy (2008), John Kane examined how American statesmen, from the founding fathers to President Bush, had attempted to reconcile their faith in a virtuous America with a national history stained by the exercise, occasionally brutal, of military power. When it came to Vietnam, the dilemma was said to be particularly acute. "Americans after Vietnam," Kane argues, "could no longer confidently assert their own values or feel comfortable about imposing them on others, and were consequently at a loss as to what to do with their own predominant power" (Kane, 2008: 337). The dilemma was not lost on Jeane Kirkpatrick. Commenting on the anti-Vietnam War movement's challenge to the legitimacy of American power and society, she argued, 
As long as the United States was perceived as a virtuous society, policies that enhanced American power were also seen as virtuous. Morality and American power were indissolubly linked in the traditional conception. But with the U.S. defined as an essentially immoral society, valuing and/or enhancing American power were perceived as immoral (Kirkpatrick, 2004: 236).

In order to undercut the lessons of Vietnam which emphasised the limits of power, the arrogance of power, and the unwise application of power, neoconservatives sought to re-moralise American power. To accomplish this feat, they first aimed to deimmoralise the Vietnam War. American intentions in Vietnam, according to Norman Podhoretz, were beyond reproach. American goals were simple: "to save the Southern half of that country from the evils of Communism" (Podhoretz, 1982b: 197). The war was said to be "fought for the sake of an ideal," the ideal of defending South Vietnam from totalitarianism (Podhoretz, 1982b: 197).

This is the central thesis of Podhoretz's Why We Were in Vietnam (1982b). The Vietnam War, according to this volume, was neither immoral nor irrational given the importance successive presidential administrations assigned to Indochina. Relying on his customary rhetorical pugnacity, Podhoretz attacked many anti-war critics. For those concerned with the deaths and suffering of innocents, Podhoretz replied that there had been more civilians killed throughout the Korean War than in Vietnam. For those who believed America's deeds at My Lai were representative of the way in which the American military behaved in Vietnam, Podhoretz argued that there was "no evidence" to support such a conclusion (see Podhoretz, 1982b: 187-188). In his attempt to de-immoralise the Vietnam War, Podhoretz concluded thus:

When Ronald Reagan, an unrepentant hawk, called the war 'a noble cause' in the course of his ultimately successful campaign to replace Carter in the White House, he was accused of having made a 'gaffe.' Fully, painfully aware as I am that the American effort to save Vietnam from Communism was indeed beyond our intellectual and moral capabilities, I believe the story shows that Reagan's gaffe was closer to the truth of why we were in Vietnam and what we did there, at least until the very end, than Carter's denigration of an act of imprudent idealism whose moral soundness has been so overwhelmingly vindicated by the hideous consequences of our defeat (Podhoretz, 1982b: 210). 
For the present study, the accuracy of Podhoretz's argument is less important than its purpose. The attempt to de-immoralise the Vietnam War was the beginning of the neoconservative attempt to revive the belief that American power is a force for good in the world. If the war which saw American power de-legitimised could be reinterpreted in a way that exposed the viciousness of North Vietnam, rebutted some of the extravagant claims of the anti-war left, and ennobled the sacrifices of American forces, then the goodness of American power could once again be believed in. Furthermore, if such a project was successful, then the national inhibitions encumbering the use of American power would be, if not removed, at least lifted so as to make the exercise of American power more palatable. As his support for the idea of preventive war indicates (discussed below), Podhoretz encouraged Americans to believe in the morality of American power because he wished to see American power unapologetically exercised.

It is important to note, however, that Podhoretz had in fact initially opposed the Vietnam War. ${ }^{152}$ In the late 1960s and early 1970s, a time when he was Editor-in Chief of Commentary, the popular Jewish journal published a number of articles very critical of the conflict and how it was being waged, the titles of which reflect the general tenor of the author's argument. In 1971, Commentary published a piece by Nathan Glazer entitled "Vietnam: The Case for Immediate Withdrawal." It also published a large number of articles written by Hans Morgenthau, articles which examined the limits of American power, the wisdom of America's foreign policy in Indochina, and the limitations of justice in international politics. ${ }^{153}$ Podhoretz himself, writing also in 1971, questioned not the prudence of the war, but the "moral soundness" of America's actions in Vietnam. "If Vietnamization originally seemed to mean turning the war over to the South Vietnamese to fight as best they could by themselves," he argued when addressing the Nixon-Kissinger administration's unlimited use of airpower in Indochina,

it has now apparently come to mean turning only the war on the ground over to the South Vietnamese while we go on bombing South Vietnam, North Vietnam,

\footnotetext{
${ }^{152}$ For an interesting review of Podhoretz's views on Vietnam and his evolution as a foreign policy thinker, see Fallows, 1982; and Gerson, 1995.

${ }^{153}$ For an interesting sampling, but by no means an exhaustive list, of articles Morgenthau wrote throughout this period, see Morgenthau, 1961; 1962; and 1963. For the most comprehensive account of his views on Vietnam, see Morgenthau, 1965.
} 
Laos, and Cambodia at a rate which continues to defy comprehension, so great is it and so disproportionate in its destructiveness to any conceivable objective (Podhoretz, 1971).

Nowhere, though, does Podhoretz attempt to reconcile the moral reservations he had expressed about the war throughout this period with his ex post facto confidence in the moral rightness of America's actions in Vietnam. He had come to conclude that "Imprudent though it might have been to try to save South Vietnam from Communism, it was also an attempt born of noble ideals and impulses" (Podhoretz, 1982: 172). Podhoretz failed to reconcile these views, or even adequately explain the disjuncture, because he wished to arrest the loss of faith in American power. He did not wish to endorse the views of those who emphasised the ignobility of America's military might, even if he had once articulated similar views. After all, Vietnam may have been "imprudent," but America was in the midst of the Cold War; it could not afford, according to Podhoretz, to be hamstrung by liberal and pacifist guilt. In one of his publications released just two years before his reinterpretation of the Vietnam War, the subtitle of his book asked readers, "Do we have the will to reverse the decline of American power?" 154 By expurgating and indeed sanctifying the Vietnam War, Podhoretz was doing his best to manufacture that will.

As the years passed, and as Vietnam receded, however faintly, in the minds of many Americans, there were a number of neoconservatives who joined Podhoretz in his attempt to re-moralise American power. In addition to being one of the most significant historical interpretations of the thirteen year conflict between Nicaragua and the United States, Robert Kagan's A Twilight Struggle: American Power and Nicaragua 1977-1990 (1996), argued that American power, even when applied in limited ways, could serve moral ends and implant the seeds of democracy in foreign lands. Embarking upon "a radical course immediately upon Somoza's overthrow," the Sandinistas, according to Kagan, were dislodged in 1990 as a result of a number of factors. Foremost among them, though, was the Reagan administration's decision to arm the contras. "As long as the contras were armed and in the field, the possibility of overthrow existed," Kagan argued (Kagan, 1996: 722). When the Sandinistas agreed to hold elections in February 1990, "it was clear," so it was claimed, "that the

\footnotetext{
${ }^{154}$ The book I am referring to is Podhoretz's The Present Danger: Do We Have the Will to Reverse the Decline of American Power? (1980b).
} 
armed rebels played decisive roles" in exerting pressure on the Marxist government to hold an election they mistakenly assumed they would win (Kagan, 1996: 722). American power, even when applied modestly and minimally, could assist others achieve the moral goal of self-government. This was one of the dominant arguments in Kagan's volume on America's involvement in Nicaragua.

As I suggested in an earlier chapter, the real turning point making it possible to once again believe in the virtue of American power, came in the Balkans throughout the 1990s. Neoconservatives were always searching for evidence that American power was a force for good in the world. When genocide erupted in Bosnia, there was an opportunity for American power to serve a moral purpose, to advance the national idea. According to Joshua Muravchik, there was little danger in American assertiveness throughout this period, for the real danger, "as the poor Bosnians could tell us, comes from the opposite direction: from an American abdication of power" (Muravchik, 1992: 37). When William Kristol and Robert Kagan spoke of America's victory in Kosovo, they claimed that America's triumph demonstrated "that American power, even when less than artfully applied, is a potent force for international peace, stability, and human decency" (Kristol \& Kagan, 1999).

For neoconservatives such as Muravchik, Kristol, and Kagan, the Balkan wars were an opportunity to revive the national faith in the virtue of American power. Although "many problems remain in the former Yugoslavia, and perhaps always will remain, those who claimed that the United States could do nothing to improve the situation have been proved wrong," Kristol and Kagan rejoiced (Kristol \& Kagan, 1999). By the end of the Balkan wars in the 1990s, the embers of Vietnam were no longer as strong as they once were, for American power, so it was believed, had redeemed itself before a passive Europe and a sceptical world.

With a reinterpretation of the Vietnam War, the "success" of Reagan in Central America, and the bombing of a genocidal dictator in the Balkans, neoconservatives felt confident in the strength of American ideals and in the morality of American power. Far from shattering this confidence, the terrorist attacks of September 11, 2001, assisted neoconservatives in their attempt to revive the national faith in the morality of American power. "The appalling acts of fanatical terrorists restored to Americans, more viscerally than anything had done since the end of World War II," argues Kane, "a feeling of innocence, albeit in the form of innocence offended" (Kane, 2008: 403-404). The attacks unified the country, fostering a large degree of 
confidence in the national creed which is customary in times of calamity, war, and travail. A number of neoconservatives recognised that it was a propitious time to convince Americans of the universal allure of their national ideals and the justifiability of their wrath. ${ }^{155}$ As Kagan put it, "America did not change on September 11. It only became more itself” (Kagan, 2003: 85). Americans, perversely assisted by al-Qaeda, had become more idealistic, more assertive, and more confident in the morality of their nation's power.

Yet having faith in the morality of power is not the same as having faith in the efficacy of power. In order to rebuild confidence in American power, Americans needed to be convinced not only of its inherent goodness, but of its effectiveness. In fact, as I explain below, these goals were inter-linked. Making American power more effective made American power more moral, so it was believed and endlessly argued. In the task of enhancing the efficacy of American power, neoconservatives displayed the same level of dedication and persistence that characterised their concomitant attempt to remind Americans of the morality of their nation's military might. When it came to making American power more usable, neoconservatives undoubtedly excelled.

\section{The RMA and Albert Wohlstetter}

In addition to reinterpreting the Vietnam War, neoconservatives sought to re-moralise American power by exploiting what strategic analysts describe as the Revolution in Military Affairs (RMA). Neoconservatives who emphasised the importance of capitalising on America's lead in the RMA have embraced ideas promoted by obscure Pentagon officials such as Andrew Marshall and strategic analysts such as Albert Wohlstetter, displaying a fascination with the impact technological innovations can have on the conduct of warfare. ${ }^{156}$ Exploiting and capitalising on the RMA, it was

\footnotetext{
155 This latter assertion is no overstatement. In Why we Fight: Moral Clarity and the War on Terrorism, William Bennett, the neoconservative mentor of William Kristol who served under Bennett when Bennett was Ronald Reagan's Secretary of Education, entitled one of his chapters, "The Morality of Anger."

${ }^{156}$ For an excellent overview of the influence of these two strategic thinkers, see Bacevich, 2006: Ch. 6. Although this chapter focuses more on Wohlstetter, there have been a number of short articles about and interviews with Marshall that provide useful summaries of his views on the RMA, and the rise of China. For a sampling of these articles, see Boyer, 2006; Kaiser, 2000; and Schwartz, 2005. For an article that Marshall wrote himself on strategy and what makes a strategic thinker, see Marshall, 1991. In addition to the articles cited below and Bacevich's chapter in The New American Militarism: How
} 
hoped, would perpetuate America's military preponderance, consolidating its lead over other potential great powers in the international system. "The goal of transformation," Paul Wolfowitz argues, "is to maintain a substantial advantage over any potential adversaries in key areas such as information warfare, power projection, space and intelligence" (Wolfowitz, 2001: 49). Max Boot, neoconservative author of War Made New: Technology, Warfare, and the Course of History 1500 To Today (2006), provides his own gargantuan account of four signal military revolutions, beginning with the gunpowder revolution and concluding with the information revolution. The theme of the book, as Boot himself states, "is the importance of not missing out on the next big change in warfare" (Boot, 2006a: 469). True to the dominant theme, Boot advises American policy-makers not to become complacent in an era in which American military power appears insuperable:

America's early lead in the Information Revolution can easily be lost - it may be being lost already - if it does not stay at the forefront of military developments.

Other countries and even subnational entities such as al Qaeda have an opportunity to exert power that would have been unthinkable before the spread of personal computers, cell phones, satellite navigation devices, and other Information Age technologies (Boot, 2006a: 16).

Albert Wohlstetter, a product of the intellectual climate of RAND in the 1950s and 1960s, the Santa Monica based think tank which encouraged its strategic thinkers to develop heterodox ideas and think the unthinkable, is one of the key figures behind the arguments of those emphasising the importance of America maintaining its lead in sophisticated technologies and weaponry. His influence on Wolfowitz and Perle is particularly pronounced. "Wohlstetter is a much more relevant figure," Wolfowitz explained as he attempted to debunk the conspiracy theories relating to Leo Strauss in his previously cited 2003 interview with Sam Tanenhaus (Wolfowitz, 2003). For Richard Perle, Albert Wohlstetter also looms large. In An End to Evil: How to Win the War on Terror (2004), a book he co-wrote with President Bush's former speechwriter, David Frum, Perle dedicates the volume to Wohlstetter, describing him at one point as “one of America's great strategic thinkers" (Frum \& Perle, 2004: 176). 
Perle also made sure throughout the course of my 2007 interview with him that he emphasised the importance of Wohlstetter (Perle, interview, 23 February 2007). Andrew Bacevich has even identified him as the pivotal figure in developing ideas which would culminate "some four decades later in a fully developed argument for preventive war as the cornerstone of U.S. strategy" (Bacevich, 2006: 154). He is, in short, a figure whose ideas are worthy of some consideration.

Although Wohlstetter wrote about a number of strategic issues, his goal was quite simple: he wished to make American power more usable by making it more discriminate. By making American power more discriminate, so the thinking went, one manages to both enhance the range of options available to policy-makers and cleanse war of its attendant horrors. "When one improves the ability to destroy a target by increasing one's accuracy," Wohlstetter explained, "there is a corresponding decrease in collateral damage" (Wohlstetter, 1983). Such an argument certainly appealed to Wolfowitz. "Albert Wohlstetter was one of the first people, most influential people," he stated, "to understand what a dramatic difference it would make to have accurate weapons" (Wolfowitz, 2003). Indeed, this was a constant theme of Wohlstetter's work. In articles for Commentary and Foreign Affairs, Wohlstetter questioned the logic of "MAD" - the notion that deterrence rested upon the promise of unrestrained nuclear warfare. "Anti-nuclear arguments proceed from premises about the inevitable dependence of deterrence on threats deliberately or uncontrollably to kill innocents," he lamented (Wohlstetter, 1983). Such premises, according to Wohlstetter, were questionable both in terms of morality and strategy. "We have urgent political and military as well as moral grounds for improving our ability to answer an attack on Western military forces with less unintended killing, not to mention deliberate mass slaughter" (Wohlstetter, 1983).

In contrast, Wohlstetter argued that even a nuclear war could be kept limited if one refrained from threatening to target an adversary's major cities and confined a nuclear exchange to "legitimate military targets" (Wohlstetter, 1983). The former option was said to be less than credible, for few policy-makers would ever contemplate destroying another nation, especially if the nuclear provocation had not resulted in the mass amount of casualties advocates of "MAD" anticipated. As Wohlstetter put it, "indiscriminate Western threats paralyze the West, not the East" (Wohlstetter, 1983). The goal was always to give policy-makers more options, options which did not include abject surrender in the face of Soviet aggression and 
options which did not require the obliteration of another nation. "The West has limited options and needs more and better ones in order to deter the plausible attacks," he argued (Wohlstetter, 1985). Regardless of whether it was Wohlstetter's concerns expressed throughout this period, or the arguments promoted by RMA enthusiasts, the goal was clear: "The real imperative," explains Andrew Bacevich, "was to enhance the ability of the United States to fight, whether all-out wars or limited ones, whether brief or protracted, whether employing nuclear or conventional weapons" (Bacevich, 2006: 153-154).

American power, in short, would be hoarded, mobilised, and used. The only questions worthy of discussion related to the conditions upon which it should be exercised and the ends it could serve, but there was no doubt among neoconservatives that the information revolution transformed the nature of contemporary warfare. As the Cold War ended and the 1990s progressed, Wohlstetter even began to provide answers to the above questions, writing a number of articles for The Wall Street Journal in which he trumpeted the threat posed by Saddam Hussein's Iraq, emphasised the savagery of Bosnian Serbs, and spoke of the ineffectiveness of the nuclear non-proliferation regime. ${ }^{157}$ Wohlstetter became one of the earliest advocates for toppling Saddam Hussein and replacing his Baathist dictatorship with a liberal democracy committed to ending human rights abuses in Iraq. In an article published by The Wall Street Journal in 1992, he argued,

Ending the totalitarian dictatorship in Baghdad - not just ousting Saddam - is necessary to stop the slaughter of Iraqis. It is needed also to prevent the obstruction of U.N. inspection teams. U.N. resolution 688 rightly identifies Iraq's repression of its own people as a 'threat to peace and security in the region.' Without an end to the torture and slaughter of dissidents, the people of Iraq can exercise no internal restraint on the tyranny's ambitions to expand military power and to turn chemical, biological or some nuclear material and facilities from civilian to military use without warning. Inspecting nine ministry buildings to uncover Iraq's secret plans, or even bombing them, will not prevent Baghdad from making and delivering chemical or biological weapons a year or so from now (Wohlstetter, 1992).

${ }^{157}$ For a small sampling, see Wohlstetter, 1992; 1994a; 1994b; and 1995. 
In order to topple the Baathist dictatorship, Wohlstetter recommended exploiting the gains made in advanced technologies:

The coalition should design measures against Iraq, whether economic or military, to save Iraq's tortured subjects, and to get rid of the dictatorship rather than just to bother it. Desert Storm's planners stressed the need to aim force at military force and to avoid harming civilians as much as possible. The military moves to protect the Shiites as well as the Kurds, just announced by Britain, France and the U.S., can do that. And, if these moves are openly directed to precise political goals, they may make feasible a free, unfragmented Iraq. These moves can involve the precise and discriminate air power and the reconnaissance, communications and other information technologies displayed in Desert Storm, but also some older ones used by Radio Free Europe, Radio Liberty, and the BBC to help the subjects of the former Warsaw Pact rid themselves of their totalitarian rulers (emphasis added) (Wohlstetter, 1992).

Albert Wohlstetter's ideas have been just as influential within neoconservative circles as Bernard Lewis's. Both Perle and Wolfowitz, not to mention the public intellectuals making the case for war in Iraq in 2003, displayed an unshakeable, an unwavering, and ultimately inexcusable confidence in what American power could achieve in Iraq. They spoke of American power with reverence and awe, relishing the fact that the United States has excelled where other nations in the international system have not. The "Kosovo conflict at decade's end," argued Robert Kagan, “exposed a transatlantic gap in military technology and the ability to wage modern warfare that would only widen in subsequent years" (Kagan, 2003: 22). This gap, according to Kagan, "only made Americans even more willing to go to war than Europeans" (Kagan, 2003: 23). Such confidence in American power and such a willingness to use it were in no small measure fostered by Wohlstetter. "For his part," argues Bacevich, "Wohlstetter believed that precise and discriminating U.S. military capabilities now made a policy of regime change feasible, if only responsible political authorities had the wit and gumption to act" (Bacevich, 2005: 165). Wolfowitz and Perle were the main political authorities who inherited Wohlstetter's faith in the transformative potential of American power. It was a faith on display in the lead up to the 2003 Iraq 
War as both men dismissed the need to conduct the unwelcome tasks of nationbuilding. The war would be moral, quick, decisive, and discriminate. America would be greeted as liberators and permitted to go home almost as quickly as they arrived. This, at least, was the hope.

\section{"Freedom's Messy"}

In the lead up to the 2003 Iraq War, Paul Wolfowitz publicly chided those who questioned the impending war against Saddam Hussein's Iraq. His most famous verbal stoush was with the army chief of staff, Eric Shinseki. His "rebuttal" of Shinseki's prediction that America would require several hundred thousand troops to police and rebuild post-war Iraq is cited regularly by critics of the war as confirmation of the Bush administration's naiveté. ${ }^{158}$ Dismissing Shinseki's prediction as “wildly off the mark," Wolfowitz claimed before a congressional committee on Capital Hill that "it is hard to conceive that it would take more forces to provide stability in postSaddam Iraq than it would take to conduct the war itself and to secure the surrender of Saddam's security forces and his army - hard to imagine" (Cited in Ricks, 2006: 9798). Privately, according to Thomas Ricks, a senior military analyst for the Washington Post and author of Fiasco: The American Military Adventure in Iraq (2006), one of the sharpest and best examinations of the early years of the Iraq War, "Wolfowitz told senior Army officers around this time that he thought that within a few months of the invasion the U.S. troop level in Iraq would be thirty four thousand" (Ricks, 2006: 97). Seemingly discarding his concerns expressed throughout the 1990s in relation to democracy promotion, Wolfowitz had no doubt that Iraq possessed the pre-conditions necessary for the emergence of a democratic state. There was, he believed, "a great opportunity to liberate one of the most talented populations in the Arab world" (Wolfowitz, 2002/2004: 151).

Richard Perle was even more hopeful that America could achieve a quick exit. He invested his hopes in Ahmed Chalabi, an Iraqi dissident whose family had fled Iraq in 1958. Constantly dogged by allegations of financial improprieties, Chalabi was a well-connected Washington lobbyist committed to ousting Saddam. Chalabi, according to David Phillips, “envisioned himself as Iraq's great new leader - like

${ }^{158}$ See, for instance, Bacevich, 2005; Packer, 2005: 114-117; and Ricks, 2006: 96-100. 
Saladin, who unified the 'land between two rivers' and then sent his armies into battle across the region" (Phillips, 2005: 70). Although sincere in his desire to rid Iraq of Saddam's tyranny, Chalabi, by most accounts, was not overly scrupulous in the means he employed to acquire American support to free Iraq. He has been accused of funnelling questionable intelligence to U.S. authorities in the lead up to the war; manipulating the American press; and goading Paul Bremer, the civilian head of the Coalition Provisional Authority (CPA) in Iraq until his departure in June 2004, to disband the Iraqi army and dismiss a large amount of civil servants with detailed knowledge of Iraqi infrastructure because of their tenuous affiliations with the Baath Party. ${ }^{159}$ Chalabi, in turn, hoped they would be replaced by loyal apparatchiks. ${ }^{160}$ Yet the responsibility for what happened in Iraq, it should be noted, does not rest with Chalabi. As Peter Galbraith put it,

Thousands of exiles have come to Washington seeking U.S. support for their causes back home. Rarely do they get more than coffee and sympathy. Chalabi got the U.S. military and hundreds of billions of dollars in U.S. expenditures on building a new Iraq. Any fault lies not with Chalabi but with the U.S. government officials who uncritically accepted what he was saying (Galbraith, 2006: 86-87).

One such official, in addition to those more influential officials such as Vice President Dick Cheney and Secretary of Defense Donald Rumsfeld, was Richard Perle. American occupation mistakes in Iraq have been well documented, which included of course the failure to deploy an adequate amount of troops to preserve order in the aftermath of the war. ${ }^{161}$ Yet Perle remains convinced that America should have ardently backed Chalabi and the Iraqi National Congress. The big mistake, according to Perle, was not that America went in unprepared to assume governing responsibilities in Iraq, but that America went in and too quickly embraced

\footnotetext{
${ }^{159}$ For interesting assessments of Chalabi's influence, see Galbraith, 2006: 82-87; and Phillips, 2005 : Ch. 7.

${ }^{160}$ Referring to the former Commander in Chief of U.S. Central Command, Anthony Zinni, Ricks argues, "Zinni believed Chalabi had manoeuvred Bremer and his subordinates into the moves. 'I think de-baathification and the dissolution of the army was at Chalabi's insistence,' he said. 'Because Chalabi wanted to replace the Baathists at every level with his people. Iraqis told me this, Iraqis from inside during the war said that Chalabi was pushing Bremer to get rid of all of the Baathists because he wanted to put his people in those positions"” (Zinni cited in Ricks, 2006: 163-164).

${ }^{161}$ For the most comprehensive accounts of the mistakes made in the opening years of the Iraq War, accounts which I have and will continue to draw on throughout this chapter, see Diamond, 2005; Galbraith, 2006; Gordon \& Trainor, 2006; Packer, 2005; and Phillips, 2005.
} 
those responsibilities. "Our choice," Perle and Frum argue, "was either to work with Chalabi or to rule Iraq ourselves - and unfortunately we backed ourselves into that second alternative" (Frum \& Perle, 2004: 131). When I asked Perle whether Chalabi and the Iraqis had the power to police post-war Iraq in 2003, he responded in all seriousness by saying that "they could not have done any worse than we did" (Perle Interview, 2007).

Wolfowitz and Perle were not the only neoconservatives supportive of quick exists and clean wars. Many of their views were loudly echoed outside the administration by Charles Krauthammer. In the immediate aftermath of September 11, 2001, and as the war in Afghanistan raged as America attempted to dislodge the Taliban, the Islamic government sheltering al-Qaeda, Krauthammer became indignant at the arguments of those who spoke of "nation-building" and "liberation." America went to Afghanistan, he argued, not to nation-build or liberate, but to "avenge" the deaths of those "murdered Americans and to protect the rest by killing those preparing to murder again. That defines our mission: destroying al-Qaeda and the Taliban. What comes next will be an interesting problem," he blithely concluded. "But it comes after" (Krauthammer, 2001c).

The way in which Krauthammer discusses American power lends considerable credence to George Packer's observation that neoconservatives see "American power in almost messianic terms" (Packer, 2005: 74). In an article criticising those who believed the Bush administration should embrace the tasks of nation-building in Afghanistan, Krauthammer responded in a way that bespoke the awe with which neoconservatives speak and think about American power:

Now that Afghanistan is post-Taliban, many are calling for American troops to join the soon-to-be-deployed peacekeeping force there. Wrong again. The United States should help the peacekeepers with logistics and, if necessary, air support. But no American peacekeeping troops. Why? Because the American military is the world's premier fighting force, and ought to husband its resources for just that. Anybody can peacekeep; no one can do what we did in Afghanistan. Many nations can do police work; only we can drop thousand-pound bombs with the precision of a medieval archer. Peacekeeping is a job for others (Krauthammer, 2001d). 
Nation-building, in short, was not big on the list of priorities for Wolfowitz, Perle and Krauthammer, just as it was not big on the list of priorities of the Bush administration. It was, after all, Donald Rumsfeld who, just weeks before the Iraq War, delivered a speech entitled "Beyond Nation-Building." It was a speech in which, according to Michael Gordon and Bernard Trainor, Rumsfeld implied that

The United States could oust a dictator, usher in a new era in Iraq, shift the balance of power in the Middle East in the United States's favour, all without America's committing itself to the lengthy, costly, and arduous peacekeeping and nation-building, which the Clinton administration had undertaken in Bosnia and Kosovo (Gordon \& Trainor, 2006: 152).

What, exactly, the administration expected to be doing in Iraq when Saddam was deposed has never really been clarified. "There was a tendency among supporters of the war," Francis Fukuyama fairly argues, "to believe that democracy was a default condition to which societies would revert once liberated from dictators" (Fukuyama, 2006: 116). A free Iraq, so it was thought, would be the outcome of an efficient and discriminate display of American power.

The post-war failures became painstakingly evident in the years following the removal of Hussein. "Mistakes were made at virtually every turn," argues Larry Diamond, one of America's most distinguished scholars on democracy promotion (Diamond, 2005: 279). "We never had enough troops in Iraq - particularly at the beginning," he explained, "when it was vital to secure public buildings, streets, and weapons depots; to hunt down remnants of Saddam's forces; to seal the borders; and to establish decisive authority" (Diamond, 2005: 288). Upon entering Iraq, American and coalition troops numbered 145,000, and they were neither equipped nor trained to undertake the tasks of nation-building. The consequences of the failure to secure Iraq in the aftermath of the war were the inevitable consequences of a war plan, "perhaps the worst war plan in American history," as Thomas Ricks put it, which showed little appreciation of what was required to successfully promote democracy in the world (Ricks, 2006: 116). As a result of not providing security in the aftermath of the conflict, Bathsheba Crocker recalls, "Iraqis went on a massive looting spree in the first weeks after Baghdad fell." "Across the country," Crocker explains, "government buildings, schools, hospitals, museums, and key infrastructure sites were completely 
ravaged; looters stole everything from computers and ancient artefacts to copper electrical wires and ceilings tiles" (Crocker, 2004: 268). There was a major "disconnect," Thomas Ricks concludes, between the goal of democratising Iraq, to say nothing of the broader Middle East, and the war plan under which this goal would be achieved (see Ricks, 2006: 116).

The major problem was the collapse of civil society in Iraq and the reluctance of the Bush administration to engage in nation-building. As for Wolfowitz's pre-war argument that America would need fewer troops to police Iraq in the aftermath of the war than it would need to conduct the war, there was little existing evidence capable of supporting such an expectation. "Such expectations," James Dobbins concludes, "were not based upon American experience in Somalia, Haiti, Bosnia, Kosovo, or Afghanistan. In each of those instances, the military manpower requirements for stabilization had greatly exceeded those for combat" (Dobbins, 2006: 223). ${ }^{162}$ The violent anarchy which prevailed in Iraq after Saddam was deposed, exacerbated by the orders issued by Bremer in May of 2003, contributed to what became a very complicated and violent insurgency, made up of a number of disparate sectarian and jihadist groups with sharply diverging objectives. ${ }^{163}$

Furthermore, post-war failures contributed, according to most observers, to the growing hostility directed towards America. In instances when the state or an occupying power is unwilling or unable to provide security, Toby Dodge argues, "people will look to whatever grouping, militia or identity offers them the best chance of survival in times of profound uncertainty" (Dodge, 2007: 88). Notwithstanding the question as to whether Iraq had the social and political pre-conditions necessary for the emergence of a democratic state, one of the tragedies of Iraq is that there was nothing destined to occur irrespective of the decisions made by the war's architects. ${ }^{164}$ "There is nothing inevitable," Dodge concluded when discussing Iraq's violent

\footnotetext{
${ }^{162}$ Dobbins goes on to explain that in "Somalia and Haiti, American forces gained entry without firing a shot, but in each case, 20,000 soldiers and marines were subsequently deployed to establish security. In Bosnia and Kosovo, airpower alone had sufficed to secure unchallenged access, but then 60,000 and 45,000 NATO soldiers, respectively, had been deployed to establish and maintain security. In Afghanistan, a few hundred Green Berets were sufficient, with the support of the indigenous Northern Alliance forces and American airpower, to chase the Taliban from power, but then nearly 25,000 U.S. and international troops were needed to establish even minimal order and contain the residual insurgency" (Dobbins, 2006: 223).

${ }^{163}$ For two interesting accounts of the insurgency in Iraq and its disparate elements, see Hafez, 2007; and Nance, 2007.

${ }^{164}$ Although Iraq was always going to be difficult (after all, it did lack the national unity often required for the emergence of a successful democratic state), there was nothing inevitable about the violence which, at the very least, could have been mitigated by a wiser post-war occupation policy.
} 
descent into chaos, "about the unfolding of this process; the primary cause is the collapse of the state and the subsequent security vacuum, not the communalistic conflict that emerges in its wake" (Dodge, 2007: 89).

Notwithstanding Krauthammer's frequently expressed belief that it was decades of Baathist repression which radicalised Iraq's Sunni population, making the violence in the aftermath of the war somewhat inevitable, Iraq was never destined to become the bloody civil war it became. ${ }^{165}$ In 2006, after Sunni radicals had escalated their campaign of violence against Iraqi Shiites, including the bombing of the venerated Shiite mosque in the City of Samarra in February, Krauthammer dismissed those who were debating whether Iraq was in the throes of a civil war. When a minority was violently rebelling against a majority to prevent it from dominating them, he concluded, "that is civil war, and there's nothing new about it" (Krauthammer, 2006). The cavalier way in which Krauthammer spoke of the tragedy engulfing Iraq reflected his previously cited belief that what happens after dictators are deposed is "an interesting problem." It was by no means considered an imperious one.

When Iraq imploded, a large portion of the responsibility rested with a set of actors and intellectuals, as Peter Galbraith put it, whose "most catastrophic assumption about postwar Iraq was that it would be easy" (Galbraith, 2006: 89). According to Perle, Wolfowitz, and Krauthammer, precision guided weapons, satellite imagery, and light and nimble forces, nullified the need for large quantities of U.S. troops stationed in Baghdad or anywhere else in Iraq. Yet, as Robert Orr argues, "Dominance on the battlefield will be squandered if the United States does not have the tools to win hearts and minds and secure lasting peace out of its military engagements" (Orr, 2004: 9). The neoconservative project to re-moralise American power had begun with a reinterpretation of a war which had done so much to delegitimise American power, and concluded with a stentorian call to exploit advances made in sophisticated military technologies. Following America's experience in Vietnam, neoconservatives contributed in no small measure to rebuilding the national faith in American power. Yet, as America's experience in Iraq would seem to

\footnotetext{
${ }^{165}$ When referring to the roots of the civil war between Sunnis and Shiites, Krauthammer absolves American policy-makers of all responsibility, arguing, "America comes and liberates them from the tyrant who kept everyone living in fear, and the ancient animosities and more recent resentments begin to play themselves out to deadly effect" (Krauthammer, 2007a). In short, Krauthammer's analysis of the origins of Iraq's civil war goes no further than merely attributing it to "ancient animosities," a very similar analysis used to justify his opposition to American intervention in the Balkans in the 1990s.
} 
indicate, rebuilding the national faith in the morality of American power is an easier task than using that power to rebuild a shattered nation.

\section{Neocons, American Power, \& the Surge}

Two foreign policy analysts sympathetic to the Bush administration's approach to American foreign policy argue that neoconservatives themselves "differed on the military approach to Iraq" (Lynch \& Singh, 2008: 156). This is a reasonable argument, although, as I explain below, there was greater ideational continuity between neoconservatives than this argument implies. Admittedly, there were many neoconservatives who were uncomfortable with the strategy adopted by the Bush administration and advocated by Perle and Wolfowitz. America would need troops stationed on the ground in Iraq for a number of years, they warned, and should not invest its hopes exclusively in the capacity of precision guided munitions to transform Iraq into an Arab beacon of liberal democracy. Neoconservative democratic globalists, if one was to recall Krauthammer's distinction between democratic globalism and democratic realism, were more willing, indeed eager, to see American soldiers policing the streets of Baghdad. ${ }^{166}$

One such neoconservative was Max Boot. Boot, in fact, had derived a lesson from the Vietnam War which deeply informed his thinking about Iraq. In The Savage Wars of Peace: Small Wars and the Rise of American Power (2003a), Boot wrote regretfully about the mistaken lessons America's military establishment derived from Vietnam. The "notion that America erred by not waging total war against North Vietnam would shape the strategic approach of the U.S. armed forces for decades to come," he claimed (Boot, 2003a: 315). This was the faulty logic, according to Boot, which led to the Powell Doctrine, the doctrine which inter alia called upon America to employ its forces sparingly, overwhelmingly, and only when such a display of force served narrowly defined national interests. ${ }^{167}$ Yet this was the wrong lesson to take from Vietnam, Boot complained. "A large part of the problem," he argued, "was that the Pentagon did not field a force designed for counterinsurgency operations. Anti-guerrilla operations place a premium on highly skilled light infantry with a flair

\footnotetext{
${ }^{166}$ See Chapter 3 on the distinction between democratic globalism and democratic realism.

${ }^{167}$ For a more than adequate summary of the Powell Doctrine and its guiding principles, see Boot, 2003a: 318-319).
} 
for dealing with civilians" (Boot, 2003a: 299). American forces, he argued, should "have put their emphasis on cutting off the guerrillas (Viet Cong) from their population base instead of chasing the main forces all over the Highlands" (Boot, 2003a: 316). For Boot, the Vietnam War raised questions of military strategy, not morality, not prudence, and not the limits of power.

The Powell Doctrine was said to be so at odds with the way in which America fought its wars in the past that its utility should be questioned. America, according to Boot, had always found itself involved in what he called "the savage wars of peace." These were the small wars fought for limited objectives with limited numbers of troops stationed on the ground, pursuing international malefactors, protecting American citizens and interests, policing failed societies, and occasionally exploiting foreign lands and peoples (Boot, 2003a: xvi). America involved itself in these conflicts not to satisfy some narrowly conceived national interest, a requirement of the Powell Doctrine, but for a variety of reasons which supposedly reinforced the need for an expansive conception of the national interest. "These conflicts," Boot acknowledged, "might as well be called 'imperial wars' - a term that, American sensitivities notwithstanding, seems apt to describe many U.S. adventures abroad" (Boot, 2003a: xvi). Although Boot is an enthusiastic supporter of these conflicts, ${ }^{168}$ the lesson he derives from the rich number of historical case studies his volume examines is regularly reinforced: whatever the benefits of the RMA, "Only boots on the ground can guarantee a lasting peace" (Boot, 2003a: 338).

As Iraq deteriorated, Boot, consistent with his often expressed wish to see American troops policing the pax-Americana, began to emphasise the importance of keeping troops in Iraq to defuse the violence. "If we want Iraq to avoid becoming a Somalia on steroids," he argued, "we'd better get used to U.S. troops being deployed there for years, possibly decades, to come" (Boot, 2003b). As things went from bad to worse, many neoconservatives began to question, if not categorically reject, Rumsfeld's way of war. "Serious errors have been made - and made, above all, by Donald Rumsfeld's Pentagon," Kagan and Kristol argued in 2004. "The recent violence in Iraq," they added, "has confirmed that the level of American military forces has been too low to accomplish the president's mission ever since the invasion phase of the war ended last April” (Kagan \& Kristol, 2004b). After the Bush-Kerry

\footnotetext{
${ }^{168}$ Boot concluded his study by arguing, "America should not be afraid to fight 'the savage wars of peace' if necessary to enlarge 'the empire of liberty"' (Boot, 2003: 352).
} 
election of 2004, Kristol became even more emphatic, claiming, "surely Don Rumsfeld is not the defense secretary Bush should want to have for the remainder of his second term" (Kristol, 2004b). In 2005, the Project for a New American Century sent an open letter to Congress insisting that the congressional leadership vote to enlarge the size of the American armed forces. It was a letter signed by a number of liberal hawks such as Peter Beinart, and an even greater number of neoconservatives, including Kristol, Boot, Kagan, and Muravchik. It began thus:

The United States military is too small for the responsibilities we are asking it to assume. Those responsibilities are real and important. They are not going away. The United States will not and should not become less engaged in the world in the years to come. But our national security, global peace and stability, and the defense and promotion of freedom in the post-9/11 world require a larger military than the one we have today. The administration has unfortunately resisted increasing our ground forces to the size needed to meet today's (and tomorrow's) missions and challenges (Letter to Congress on Increasing U.S. Ground Forces, 2005).

By 2006, a number of neoconservatives came close to giving up on Iraq. Their calls left unheeded, they felt America had been taken to war by an administration deficient in battlefield nous. Boot, while continuing to prefer that additional troops be sent to Iraq, was willing to entertain "radical ideas" to improve the ailing security situation. He even called upon the Bush administration to consider drastically reducing American troops “from today's level of 130,000 to under 50,000 and changing their focus from conducting combat operations to assisting Iraqi forces" (Boot, 2006b). This, he believed, may have been the only way to "catalyze the Iraqis into getting their own house in order" (Boot, 2006b).

Other neoconservatives, though, remained steadfast in their support for sending more troops. Kagan, writing for the New Republic in November 2006, questioned those who spoke of encouraging Iraqis to find some form of political accommodation among the rival sectarian groups while Iraq remained mired in civil war. "It is precisely the illusion that a political solution is possible in the midst of rampant violence that has gotten us where we are today," he argued. "What's needed in Iraq," Kagan concluded, 
are not more clever plans but more U.S. troops to provide the security to make any plan workable. Even those seeking a way out of Iraq as soon as possible should understand the need for an immediate surge in U.S troop levels to provide the stability necessary so that eventual withdrawal will not produce chaos and an implosion of the Iraqi state (Kagan, 2006c).

As Kagan wrote these words, the Bush administration itself was beginning to debate the merits of what would become known as the "surge."169 It was a debate helped along by the frequent writings of Frederick Kagan, Robert's brother, and a publication released by the American Enterprise Institute which involved many participants, none more important, though, than Fred Kagan and Jack Keane, a retired U.S. Army General. Kagan, like his brother, had written a number of articles for the Weekly Standard analysing the prosecution of the war, writings which reflected the authors firm grasp of the complexities of combat in Iraq. ${ }^{170}$ His writings culminated in a report released by the American Enterprise Institute entitled "Choosing Victory: A Plan for Success in Iraq" (2007).

Not long before the report was released, both Kagan and Keane were invited to the White House to make their case before President Bush and Vice President Cheney. ${ }^{171}$ The central message they delivered to the Bush administration emphasised the importance of switching objectives in Iraq. It was a message best summed up in the opening pages of "Choosing Victory." "Establishing security in Baghdad, and then in the violent regions that surround it," the authors of the report explained, "must become the top priority of the American military presence in Iraq today." "Securing Baghdad to bring the violence in Iraq's capital under control," the report concluded, "must be the centrepiece of a military operation that should be launched as rapidly as possible" (Choosing Victory, 2007).

When the Bush administration appointed General David Petraeus as the lead U.S. commander overseeing the war in Iraq, Petraeus, fresh from writing a new counterinsurgency manual, requested and received an additional five combat brigades,

\footnotetext{
${ }^{169}$ For a study that provides insights into the decision making process within the Bush administration leading up to the surge, see Robinson, 2008: Ch 2.

${ }^{170}$ For a sampling of Fred Kagan's writings which emphasise the importance of launching a surge, examines the success of the surge, and analyses the nature of al-Qaeda in Iraq, see Kagan, 2006; 2007; Kagan \& Kagan, 2007; and Kagan \& Kristol, 2007.

${ }^{171}$ On the details of this meeting, see Robinson, 2008: 32-35.
} 
adding an additional 31,000 troops and support personal to the American effort in Iraq. Dividing Baghdad into ten districts, the goals of the plan were as simple as its execution was hazardous: "After initial shaping operations," explains Lind Robinson, "the major phase of the plan would consist of operations to successfully 'clear,' 'control,' and 'retain,' the city neighbourhood by neighbourhood" (Robinson, 2008: 122). America would not stand down as Iraqis stood up, in short. Rather, America would stand up as insurgents and jihadists were put down. While some neoconservatives such as Krauthammer were hesitant to lend their support to this strategy, ${ }^{172}$ all came to recognise the success the surge had in reducing violence in Iraq. "The reality is that we are winning but that the war is far from over," Boot cautiously concluded in February 2008 (Boot, 2008). "We need to make a long term commitment to prevent Iraq from sliding back into the kind of civil war that began to erupt in 2006," he exhorted (Boot, 2008).

At the time of this writing, Iraq is as stable as it has been since the start of the U.S. invasion. Only recently have authors such as Linda Robinson and Bing West begun to analyse the way in which America turned around its fortunes in Iraq. ${ }^{173}$ Not wanting to overstate the chances of victory, both authors are cautiously optimistic that the strategy implemented by David Petraeus has given Iraq its best chance of developing a viable democratic society. "Decades from now," West argues, "historians will point out how Petraeus saved Baghdad" (West, 2008: 374). It is difficult to exaggerate the accomplishments of Petraeus and the soldiers he led in returning Iraq to a state of relative national tranquillity. "Petraeus, with the help of many others," Robinson argues, "pulled Iraq back from the brink of civil war and created an opportunity for the next administration to bring the war to a soft landing" (Robinson, 2008: 345). Critics of the Iraq War, detractors of the Bush administration, and American oppositionists, must confront these facts in a fair minded way that avoids the polemics and screeds of the past.

Yet the Iraq War must be judged not so much on the way in which America conducted itself in combat, itself a question which has encouraged a lively literature and has taken its cues from what IR theorists call the jus in bello requirements of just war theory, requirements which regulate a nation's conduct in war by raising

\footnotetext{
${ }^{172}$ For Krauthammer's opposition to the surge, see Krauthammer, 2007a; 2007b; and 2007c. For Krauthammer's later acknowledgment of the success of the surge, see Krauthammer, 2007d; 2007e; 2007f; 2007g.

${ }^{173}$ For the three most authoritative studies, see Robinson, 2008; Ricks, 2009; and West, 2008.
} 
questions of proportionality, discrimination, and chances of success; rather the Iraq War must be judged by analysing the ideas upon which the war itself was based. ${ }^{174}$ Battlefield success cannot vindicate flawed ideas, nor can it ever absolve policymakers of years of missteps. Saddam, as all but the most extreme would concede, was a tyrant belonging to a rare class of genocidal dictators who had used chemical weapons, invaded neighbouring countries, supported terrorism, and decimated minorities living within Iraq's borders. ${ }^{175}$ Yet the war was fought under the guidance of a new doctrine, a doctrine which had the idea of preventive war as its centrepiece. Neoconservatives became the strongest champions of this idea, perhaps reflecting the fact that their faith in American power was bound to engender enthusiasm for what is arguably a radical innovation in international politics. ${ }^{176}$

When it came to battlefield strategy in Iraq, neoconservatives were certainly divided, but they were never divided when it came to the big question on American power. Hard power, after all, is - hard power. Regardless of whether it comes in the form of precision guiding munitions striking carefully selected targets in the heart of Baghdad, or American armed forces quelling seemingly ungovernable insurgency hotbeds in the heart of Anbar Province, belief in the transformative potential of America's military might is an article of neoconservative faith. Neoconservatives have rarely been divided on questions relating to the efficacy and indispensability of American military power.

To come to terms with the wisdom and morality of the Iraq War, one must come to terms with the idea of preventive war and distinguish it from the idea of preemption, something I do below. Although I strongly question the idea of preventive war, the surge in Iraq was necessary and may very well achieve a measure of long overdue justice for the people of Iraq. "Wars," as Winston Churchill famously put it after British forces withdrew from Dunkirk, "are not won by evacuations" (Churchill, 1940: 570). Yet when America made the decision to topple Saddam, it inherited

\footnotetext{
${ }^{174}$ For a sceptical article which seeks to challenge some of the arguments of scholars and commentators who have belaboured American misdeeds in Iraq, see Kahl, 2007. For a useful discussion on just war theory, see Elshtain, 2003: Ch. 3.

${ }^{175}$ For a damning biography on Saddam which spotlights many of his egregious crimes, see Coughlin, 2002. For Saddam's crimes against the Kurds, see Hilterman, 2007; and Kelly, 2008.

${ }^{176}$ There are, it should be noted, a number of historians who have questioned how novel the idea of preventive war is in the history of U.S. foreign policy. See, for instance, Gaddis, 2004; and Trachtenberg, 2007. Historical studies, I believe, can do many fruitful things. However, it is somewhat contestable as to whether the discovery of an historical parallel, even if it is a truly legitimate one, is capable of telling us anything about the wisdom of decisions made in the present.
} 
ultimate responsibility for Iraq's progress as a nation. "You break it, you own it," as Secretary of State Colin Powell is said to have warned President Bush (see Woodward, 2004: 150). When America faced defeat in Iraq, it belatedly made the right decision to deploy more troops. A precipitous withdrawal would have advanced neither America's war against Islamic jihadism nor the humanitarian interests of Iraq. This is not to suggest that the ideas leading America to Iraq were wise. But it is to suggest that whatever the gains and losses, hopes and despairs, understated successes and inexcusable failures, caused by America's invasion of Iraq, one thing appears a little more clear now than it was in the past: "America," as West puts it, "controls how Iraq ends" (West, 2008: 375).

\section{$\underline{\text { Neoconservatism and Preventive War }}$}

After decades of trying to re-moralise American power and enhance the effectiveness of American power, neoconservatives, following September 11, 2001, embraced the idea of preventive war. It was an idea incorporated into the Bush administration's approach to American foreign policy, becoming one of the central pillars of a doctrine which itself became a source of confusion throughout the 2008 presidential election as Sarah Palin, Senator John McCain's running mate, struggled, after being asked if she agreed with the doctrine, to show any awareness of what it was. In articulating the doctrine which carries his name, President Bush delivered his oft-quoted speech in 2002 at West Point, America's major military academy, warning,

The gravest danger to freedom lies at the perilous crossroads of radicalism and technology. When the spread of chemical and biological and nuclear weapons, along with ballistic missile technology - when that occurs, even weak states and small groups could attain a catastrophic power to strike great nations (Bush, 2002: 269).

Rogue states could not be contained, Bush argued, because dictators were unamenable to rational calculation: "Containment," he stated, "is not possible when unbalanced dictators with weapons of mass destruction can deliver those weapons on missiles or secretly provide them to terrorist allies" (Bush, 2002: 269). Although the Bush Doctrine was interpreted as a collection of ideas and principles capable of guiding 
American foreign policy after September 11, there should be little doubt that the idea of preventive war was its capstone. ${ }^{177}$ As the above quotation also demonstrates, the Bush administration not only emphasised the irrationality of rogue state dictators; it also linked the threat posed by amorphous terrorist networks with the threat posed by rogue states.

When justifying the war against Iraq, neoconservatives made a similar case, underscoring the importance of acting without perfect knowledge of impending attacks and without incontrovertible evidence of links between rogue states such as Iraq and terrorist groups such as al-Qaeda. Objecting to those who insisted that Saddam was not involved in the September 11 attacks, Boot asked, "Who cares if Saddam was involved in this particular barbarity?" (Boot, 2001). The matter for Boot was a rather simple one: Saddam, he claimed, "is currently working to acquire weapons of mass destruction that he or his confederates will unleash against America and our allies if given the chance" (Boot, 2001).

Neoconservatives also linked the threat posed by rogue states with the threat posed by stateless terrorists. "The possible alliance of rogue states with such undeterrables and undetectables," Krauthammer warned when referring to "undeterrable" religious extremists and "undetectable" biological weapons, "presents a new strategic situation that demands a new strategic doctrine" (Krauthammer, 2002/2003). What was required, Wolfowitz stated shortly after the attacks, was an assertive foreign policy capable of "removing the sanctuaries, removing the support systems, ending states who sponsor terrorism" (cited in Woodward, 2005: 60). One adept investigative journalist, Ron Suskind, argued that such beliefs constituted a "one percent doctrine." Its adherents were said to believe that even if there was a "one percent chance" that terrorists planned to attack America, policy-makers should act as if it was a certainty (see Suskind, 2007: 62). There is more than enough neoconservative testimony to support such a description. "The Iraqi threat is enormous," Kristol and Kagan warned in 2002. "It gets bigger with every day that passes. And it can't wait until we finish tying up all the 'loose ends"' (emphasis added) (Kagan \& Kristol, 2002). By referring to "loose ends," one can assume that Kristol and Kagan were referring to the collection of evidence. This is the logic of prevention, not preemption.

\footnotetext{
${ }^{177}$ For two excellent examinations of the doctrine and its principles, see Jervis, 2003; and Record, 2003
} 
The question that the idea of preventive war raises is not one of imminent threat, for the question relates more to whether a threat may develop in the future if action is not taken in the present. It is a crucial distinction. As one observer notes, "Preemptive war has legal sanction. Preventive war, on the other hand, has none, because the threat is neither certain nor imminent" (Record, 2003: 7). The threat, as Just War IR theorist Michael Walzer explained, "exists in the mind's eye" (Walzer, 2006: 76). Nobody could be sure if Saddam would supply terrorists with weapons of mass destruction, so the thinking went, but the chance could not be taken. "We must," President Bush exhorted, "take the battle to the enemy, disrupt his plans, and confront the worst threats before they emerge. In the world we have entered the only path to safety is the path of action" (Bush, 2002/2003: 269).

The idea of preventive war, however, is one which should be applied very selectively, if at all. The most prominent reason why the idea of preventive war is problematic manifested itself when America was unable to find the weapons of mass destruction it assumed Iraq possessed. ${ }^{178}$ Uncertainty is the hallmark of preventive war, and there should be little surprise if the assumptions going into these wars fail to survive the ensuing hostilities. By "definition," Robert Jervis argues, "the relevant information is hard to obtain because it involves predictions about threats that reside sometime in the future" (Jervis, 2003: 370). In fact, the idea of preventive war presupposes that the threat should be removed before it even exists in its most visible form. As Michael Mandelbaum explains,

a preventive war has a self-canceling quality to it. If it is successful it removes the threat that, were it to grow to menacing proportions, would clearly justify military action. It removes, in effect, the evidence that would convince people of the wisdom of waging war (Mandelbaum, 2005: 60).

Whether this idea can be sustained in a democratic regime which often demands clarity about the purposes for which it goes to war is highly questionable. The idea of preventive war has no shortage of critics. Anatol Lieven and John Hulsman, two selfdescribed "ethical realists," argue that when neoconservatives call for a number of

\footnotetext{
${ }^{178}$ This by no means was an unreasonable assumption. Even those in the highest echelons of Saddam's regime were unsure as to whether Iraq still possessed WMD. On this point, see Woods, Lacey, \& Murray, 2006.
} 
preventive wars, they echo Cold War advocates of "roll back" such as James Burnham. Their concern, expressed in Ethical Realism: A Vision for America's Role in the World (2006), is that neoconservatives champion an idea which invites perversion by other powers in the international system. It sets "a terrible precedent for the behaviour of other countries," they argue (Lieven \& Hulsman, 2006: 37). This is a concern shared by many prominent IR scholars. As Jeffrey Record put it, "India could attack Pakistan, happily invoking the Bush Doctrine on the charge of Pakistan's sponsorship of terrorism in Kashmir. And China could attack Taiwan as a means of forestalling its threatened independence" (Record, 2003: 19). "Clearly," Francis Fukuyama concludes, "a doctrine of preventive war is not one that can be safely generalized throughout the international system" (Fukuyama, 2006: 101).

Of course, after Iraq the Bush administration balked at the prospect of fighting preventive wars against other rogue states. The same, however, cannot be said for many neoconservatives who continued to call for the waging of preventive wars against Iran and North Korea. While all neoconservatives adopted an assertive rhetorical posture against the regime in Tehran, some were a little more modest in their chosen means but no less modest in their ultimate ambition for overthrowing the mullahs. ${ }^{179}$ Norman Podhoretz, though, displayed no such modesty, emerging as the most strident neoconservative advocate for bombing Iran's nuclear facilities. In two articles for Commentary, he made, as he titled his first article, "The Case for Bombing Iran" (2007b). Despairing at the failure of sanctions which have been progressively imposed on Iran since December 2006, Podhoretz declared, "the plain and brutal truth is that if Iran is to be prevented from developing a nuclear arsenal, there is no alternative to the actual use of military force" (Podhoretz, 2007b: 21).

William Kristol agreed. Writing in July 2006 before Podhoretz published his first article and when Israel was at war with Hezbollah, the Lebanese based terrorist organisation which was created and is funded by Iran, he pushed for America to seize the opportunity and take the war to Iraq's nettlesome neighbour. "Why wait?" he asked. "Does anyone think a nuclear Iran can be contained?" (Kristol, 2006). The negative consequences of a military strike did not register with Kristol. "Yes," he argued, "there would be repercussions - and they would be healthy ones, showing a strong America that has rejected further appeasement" (Kristol, 2006). This was the

\footnotetext{
${ }^{179}$ For calls on behalf of aiding Iranian dissidents who, it is hoped, may successfully topple the Iranian regime, see Kagan, 2006; and Ledeen, 2007.
} 
ultimate expression of faith in American power. No concern for consequences, no doubt that America would prevail, no need for pause. Not to be outdone, Joshua Muravchik began an op-ed for the Los Angeles Times in a way that avoided any hint of subtlety: "We must bomb Iran," Muravchik commenced. It "has been four years since that country's secret nuclear program was brought to light," he complained with palpable exasperation, "and the path of diplomacy and sanctions has led nowhere" (Muravchik, 2006).

Neoconservatives marshal a diverse array of arguments justifying the wars they believe America must wage. In his two articles for Commentary, Podhoretz stresses the need to view Iran as merely one theatre in a global war against "Islamic-fascism" (see Podhoretz, 2007b: 17). As I demonstrated in an earlier chapter, for Podhoretz, the war on terror is very much an ideological war, one every bit as ideological as the one waged against Nazism and Soviet communism. Iran, just like Nazi Germany and the Soviet Union, he argues, is a revolutionary power deeply aggrieved by the "iniquitous" status quo. "Like Hitler," Podhoretz claims when referring to the Iranian President, Mahmoud Ahmadinejad,

he is a revolutionary whose objective is to overturn the international system and to replace it in the fullness of time with a new order dominated by Iran and ruled by the religio-political culture of Islamofascism. Like Hitler, too, he is entirely open about his intentions, although - again like Hitler - he sometimes pretends that he wants nothing more than his country's just due (Podhoretz, 2007b: 20).

Neoconservatives remain convinced that there is no way to deter rogue states such as Iran. Yet this assumption raises larger questions about rogue state deterrability and the idea of preventive war in general. There are, in fact, many astute observers of the Iranian regime who question the threat assessment of neoconservatives such as Podhoretz. For instance, Ray Takeyh, one of the sharpest analysts on Iran and its domestic politics, concludes,

The Islamic Republic is not an irrational rogue state seeking such weaponry as an instrument of an aggressive, revolutionary foreign policy designed to project its power abroad. This is not an 'Islamic bomb' to be handed over to terrorist organizations or exploded in the streets of New York or Washington. The fact is 
that Iran has long possessed chemical weapons, and has yet to transfer such arms to its terrorist allies. Iran's cautious leaders are most interested in remaining in power and fully appreciate that transferring nuclear weapons to terrorists could lead to the type of retaliation from the United States or Israel that would eliminate their regime altogether (Takeyh, 2006: 147). ${ }^{180}$

There is, of course, always a risk in downplaying the words of leaders such as Ahmadinejad who has threatened to wipe "Israel off the map" and who has "delivered firebrand speeches" throughout Iran, according to his biographer, that "compared giving up enrichment to giving up Iran's independence and stressed the moral importance of not backing down" (Naji, 2008: 133). Few serious observers, after all, are prepared to say that Ahmadinejad has not accelerated Iran's nuclear weapons program. Although Iran's pursuit of nuclear weapons pre-dates the rise of Ahmadinejad, there is no doubt, Kasra Naji argues, that Ahmadinejad "hardened Iran's position as he gradually took over the conduct of Iran's nuclear policy. He turned the issue into one of national honour" (Naji, 2008: 112). Yet it is still far from clear whether Iran, if it acquired the bomb (as I suspect it will), will begin to collaborate with terrorists, providing them with WMD to use against America or Israel or any other power. In a spirit similar to that of Ray Takeyh, Kenneth Pollack, whose book on Iraq had done much to elicit support for the U.S.-Iraq conflict, comes to a more circumspect conclusion regarding Iran in his subsequent publication, The Persian Puzzle: the Conflict between Iran and America (2005). "Iran has possessed chemical and biological weapons since the end of the Iran-Iraq War, and if it wanted to," he argues,

it could have provided these to any of the different Hizballahs it has spawned; to Hamas, to PIJ, or any other Palestinian rejectionist group; or to any of a halfdozen other groups. Tehran has never done so. It has never done so because it has never believed that these groups required such weapons and because it feared that if their use were ever traced back to Tehran, the retaliation it would suffer would outweigh any gains from the attack itself (Pollack, 2005: 419).

\footnotetext{
${ }^{180}$ As this thesis is submitted, Iran is currently in the midst of a violent upheaval in which the Iranian people have taken to the streets to protest the June 2009 election result which returned Ahmadinejad to power. The violent Iranian response to these protests certainly reinforces the degree to which Iran's rulers wish to cling to power above all else.
} 
It is more than a little debateable, in other words, as to whether Iran could not be deterred from using nuclear weapons, or even deterred from providing them to terrorists. In 2000, Condoleezza Rice had written an article for Foreign Affairs entitled "Promoting the National Interest," an article which addressed this issue directly. "These regimes," she argued when referring to rogue states such as North Korea, "are living on borrowed time, so there need be no sense of panic about them. Rather," she concluded, "the first line of defense should be a clear and classical statement of deterrence - if they do acquire WMD, their weapons will be unusable because any attempt to use them will bring national obliteration” (Rice, 2000). Although Rice departed from such principles after September 11, 2001, there is little reason why such a "classical statement of deterrence" should be considered inapplicable to the challenges posed by today's rogue states.

Furthermore, if the advocates of preventive war diminish the importance of discovering a "smoking gun" today, imagine how easy it would be to diminish the importance of acquiring evidence after a devastating nuclear attack by a terrorist group which killed millions. As Pollack put it, "in the aftermath of a nuclear terrorist attack, the victim - and its allies - are probably not going to be too concerned about how good the evidence linking it to Tehran was. Moreover," he concludes, "so unforgivable a crime would not have a statute of limitations" (Pollack, 2005: 419420). Given this reality, it is hard to imagine why any state would gamble its very existence, something no state has heretofore done, by heedlessly providing nuclear weapons to terrorist groups over which they have only degrees of control. "We have not," Fukuyama argues, "abruptly moved into a world in which rogue states routinely pass WMD to terrorists; such a world may yet emerge, but acting as if it were here now forces us into some costly choices" (Fukuyama, 2006: 84). Living with a nuclear Iran carries grave risks, but it is not self-evident that such risks are greater than those that would attend another preventive war waged in the Middle East.

Yet neoconservatives advanced the idea of preventive war not only because they assumed Iraq and Iran would distribute nuclear weapons to terrorists; they believed in the idea because they wished to preserve America's freedom of action and perpetuate America's military preponderance. "In the 1990s, much of the complacency about Saddam, both in Washington and in Europe, rested on the assumption that he could be deterred," Kagan and Kristol declared (Kagan \& Kristol, 2002). "The issue seemed to us," they objected, "not so much whether we could deter Saddam, but whether he 
could deter us: If Saddam had had nuclear weapons in 1991, would we have gone to war to drive him from Kuwait?" (Kagan \& Kristol, 2002).

What concerned Kagan and Kristol was what Podhoretz had called "Finlandization" throughout the Cold War. In its simplest terms, Finlandization referred to the Soviet Union potentially acquiring a degree of global power, probably by invading the Middle East and seizing control of the region's oil, which would dent the West's resolve to contain the Soviets, inhibit bold action, and result in a diminution of American influence. It was, therefore, no surprise to see Podhoretz apply such logic not only to Iraq in a spirit similar to that of Kagan and Kristol, but to Ahmadinejad's Iran as well. "Demented though he may be," Podhoretz argued when referring to the Iranian President,

I doubt that Ahmadinejad is so crazy as to imagine that he could wipe America off the map even if he had nuclear weapons. But what he does envisage is a diminution of the American will to oppose him: that is, if not a world without America, he will settle, at least in the short run, for a world without much American influence (Podhoretz, 2007b: 18).

Nor were Iraq and Iran the only rogue states that neoconservatives wished to see America wage a preventive war against. In a stunning display of neoconservative chutzpah, and bespeaking the ease with which neoconservatives assumed Saddam's regime would be quickly toppled, Joshua Muravchik, writing on the eve of the 2003 Iraq War, was already speaking out on behalf of a second preventive war before America had even fired a shot in its first: "Not only does the North's belligerence leave us no choice but to 'think' about war," he argued when discussing America's options for dealing with a nuclear North Korea,

we cannot exclude the possibility of initiating military action ourselves. Part of the cause of our present predicament is that we ruled out the use of force at earlier points in this saga - when, however painful, it would have been less costly than today. And today it may be less costly than a few years from now, when North Korea will have dozens of nuclear weapons and long-range missiles (it has tested one that could reach Alaska) or when it will have shared them with al Qaeda and others" (Muravchik, 2003: 38). 
Just as they did not want American power balanced throughout the Cold War, preferring an "imbalance of power" in favour of America, neoconservatives do not want American power deterred by nuclear armed rogue states. This, they know, is one of the ways weaker states can erode American hegemony. According to Stephen Walt, "Weapons of mass destruction - and especially nuclear weapons - are extremely effective instruments of deterrence, because it is too dangerous to threaten a WMD owning state with conquest or "regime change"" (Walt, 2005: 139). Nuclear weapons are the great equalisers, creating a playing field within which America is incapable of achieving all its foreign policy goals. As IR theorist Robert Gilpin argued in his classic study on hegemonic war, War and Change in World Politics (2008), "The most powerful state will think twice before attacking the smallest state armed with nuclear weapons" (Gilpin, 2008: 215).

Although Gilpin spoke about the prospects of hegemonic war in this study, much of the logic is still applicable. It also raises a number of tantalising questions which should be grappled with by IR theorists for a number of years. For instance, to what lengths will hegemons go to preserve their primacy in the face of technological innovation? To what extent does the idea of preventive war, which has now been applied in Iraq, challenge the arguments of those scholars who insist that nuclear weapons pacify the international system ${ }^{181}$ Is it wise to assume that the preventive war waged in Iraq was an historical anomaly concocted by a small group of “ideologues" and authorised by a "pliable" President? Or does the 2003 Iraq War tell us something deeper about nuclear weapons, the fears they can induce, and the lengths to which states may go in the future to prevent their proliferation in an age of religious terror? Nuclear weapons are still a relatively new innovation in international politics, and even Gilpin concludes his study by leaving it open as to how these weapons could affect the behaviour of nations in the future.

Neoconservative concerns about the proliferation of nuclear weapons among rogue states is certainly a legitimate concern, but is the idea of preventive war the only idea which neoconservatives are able to muster in order to control the proliferation of weapons of mass destruction? As a community which prides itself on its intellectualism, surely they must have other proposals for improving the current

${ }^{181}$ I am referring here to the neo-realists, or those who take their cues from Kenneth Waltz. 
non-proliferation regime, which itself may very well be on the verge of irrelevance. ${ }^{182}$ A nuclear free world, the vision of Ronald Reagan, is surely a worthy aspiration, but how is the vision to be realised? Are preventive wars the solution to the nuclear conundrum? Did neoconservatives write strong denunciations of the Bush administration's decision to assist India's nuclear program? Of course, they did not. It is not only the potential proliferation of nuclear weapons which induces neoconservative concerns; it is also the character of the regimes seeking them. "No one wants to see Iran get the bomb," Kagan argued,

but it does matter who is in power. We don't worry that France or Great Britain has nuclear weapons. We tolerate India's and Israel's arsenals largely because we have some faith that their democratic governments will not use them. Were Iran ruled by even an imperfect democratic government, we should be much less concerned about its weaponry (Kagan, 2006d).

The idea of preventive war, in short, was embraced because it was so intimately connected with other neoconservative beliefs. It was an idea which promised to accomplish so much, to preserve America's freedom of action in future conflicts, to transform brutal dictatorships into liberal democracies, to acquire the respect of the world, friends and enemies alike. Once the idea of preventive war was embraced there was an expectation that it should be applied to all rogue states in the international system. By "their very existence," Andrew Bacevich accurately argues, "dictatorships constituted an unacceptable threat" (Bacevich, 2005: 165). One can see the expectation in the articles Podhoretz wrote for Commentary over a two year period. In 2006, he expressed his "contention that the Bush Doctrine is no more dead today than the Truman Doctrine was cowardly in its own early career" (Podhoretz, 2006: 31). By 2008, he began to have second thoughts as to whether President Bush would continue to adhere to the principles of his doctrine. After the release of a 2007 National Intelligence Estimate which made it increasingly difficult for the President to justify war against Iran, Podhoretz regretfully concluded that "the forces that are blindly working to ensure that Iran will get the bomb are likely to prevail even against

\footnotetext{
${ }^{182}$ For an excellent critique of the Non-Proliferation Treaty, see Wesley, 2005. For a less critical but by no means sympathetic account of the current regulation of nuclear weapons in the world, see Cirincione, 2008.
} 
the clear-sighted determination of George W. Bush, just as the forces of appeasement did against Churchill in 1938" (Podhoretz, 2008: 19).

Among neoconservatives, there was no need to discriminate among the rogue states seeking weapons of mass destruction. All were as dangerous as each other, and all were viable candidates for a preventive war. Although neoconservatives have taken the failure to discriminate between threats to new heights, it has been a recurring tendency throughout the history of America's foreign relations. In his memoirs, George Kennan ruefully observed,

I have been struck by the congenital aversion of Americans to taking specific decisions on specific problems, and by their persistent urge to seek universal formulae or doctrines in which to clothe and justify particular actions. We obviously dislike to discriminate. We like to find some general governing norm to which, in each instance, appeal can be taken, so that individual decision may be made not on their particular merits but automatically, depending on whether the circumstances do or do not seem to fit the norm (Kennan, 1967: 322). ${ }^{183}$

Although few, if any, principles of statecraft can be categorically rejected, the idea of preventive war must be judged very carefully. The cavalier way in which neoconservatives called for a series of preventive wars is more than a little unsettling. In fact, it gives some credence to those scholars who speak of a creeping "American militarism." Yet it also reflects the immoderation of neoconservatives. In many ways, after the Cold War neoconservatives saw the proliferation of nuclear weapons among rogue states as the last remaining hurdle to perpetuating the "unipolar moment." It was one they were determined to remove.

What began as an attempt, though, to restore the national faith in the morality and efficacy of American power, culminated in the defence of an idea which entrapped the Bush administration in a war - the war in Iraq - which made American power look neither moral nor effective. In 2006, after the prisoner abuse at Abu Ghraib, after allegations of CIA torture, after over three years of a war in which the Bush administration stood by as a civil war and violent insurgency engulfed Iraq, and after

\footnotetext{
${ }^{183}$ I recognise that Jeffrey Record enlists the help of George Kennan to make a similar point. It should be noted, though, that the above quote was taken from Kennan's memoirs, not the interview Kennan gave to John Mayer of the New Yorker in 2002, which is the source Record relies on.
} 
evidence began to mount that the Taliban had renewed their war in Afghanistan, Max Boot could still confidently assert that America remained "the greatest force for good in the world, as it has been since 1942" (Boot, 2006c). Viewed in terms of what America does in the world as a whole, perhaps Boot was right. But by 2006 it was becoming a much tougher sell. What neoconservatives failed to realise is that there are limits not only to American power, but to international affairs in general. If there was one lesson of Vietnam worth absorbing, this was surely it. Reflecting on his time overseeing the war in Indochina, Robert McNamara noted,

We failed to recognize that in international affairs, as in other aspects of life, there may be problems for which there are no immediate solutions. For one whose life has been dedicated to the belief and practice of problem solving, this is particularly hard to admit. But, at times, we may have to live with an imperfect, untidy world (McNamara, 1996: 323).

\section{Conclusion}

This chapter began by emphasising how neoconservatives attempted to re-moralise American power and enhance its efficacy. This was an attempt, I argued, to lower the threshold permitting the use of force. It was an attempt, in short, to make American power more employable. Neoconservative confidence in American power was certainly on display in Iraq, and it was even more on display when it came to their uncritical embrace of the idea of preventive war. This was an idea which they wished to see consistently applied, and it was an idea which promised to achieve a number of other neoconservative foreign policy goals, including the goal of "regime change" and the goal of perpetuating American military preponderance. In the hands of its current advocates, though, it is an idea which invites indiscriminate foreign entanglement. It also raises questions about American power and responsibility. With great power, as Irving Kristol once fairly argued, comes great "responsibility - above all, the responsibility to use this power responsibly" (Kristol, 1967/1999: 91). Whether the embrace of the idea of preventive war would lead to responsible uses of American power is more than a little contestable.

Neoconservatives also embraced the idea of preventive war because it promised to prevent the doomsday prospect, one which is certainly very real and must remain a 
staple of scholarly dialogue and analysis, of terrorists acquiring weapons of mass destruction to use against America and its allies in the world. It should be noted, however, that before the terrorist attacks on September 11, 2001, neoconservatives did not spend a great deal of time writing about terrorism, preferring instead to emphasise the importance of America standing up for its ideals in the world and to warn of the perils of global multipolarity. Yet after September 11, there was an additional urgency, an urgency to do something, to retaliate, to embrace big ideas, to transform a region. It was an urgency which intensified and exacerbated the impatience which is a natural characteristic and vice of democratic regimes. "In democratic societies," the French aristocrat Alexis de Tocqueville once observed, "there exists an urge to do something even when the goal is not precise, a sort of permanent fever that turns to innovation of every kind. And innovations," he ominously concluded, "are almost always costly" (Tocqueville, 1835/2004: 241). 


\section{Chapter 7}

\section{Conclusion}

In February 2007, Barack Obama, the junior Senator from Illinois, declared his candidacy for the presidency of the United States. "We all made this journey for a reason," he told the adoring collection of well wishers who braved the freezing Illinoisan weather to listen to their favoured candidate. He continued:

It's humbling, but in my heart I know you didn't come here just for me; you came here because you believe in what this country can be. In the face of war you can believe there can be peace. In the face of despair, you can believe there can be hope. In the face of a politics that's shut you out, that's told you to settle, that's divided us for too long, you believe we can be one people, reaching for what's possible, building that more perfect union (Obama, 2007/2008: 193).

Inflated though it may be, the rhetoric and the message meant something. Obama was promising to move America beyond the polarising presidency of George W. Bush, beyond the tragedy of Iraq, beyond the maligned neoconservatives, and towards an era in which America was once again respected in the world. Sophisticated scholars of international politics may bridle at the suggestion, arguing instead that there would be more continuity in American foreign policy than campaign rhetoric suggested, but most Americans did not wish to see it that way. ${ }^{184}$ When Obama was elected America's 44 ${ }^{\text {th }}$ President in November 2008, America, and the world, spoke triumphantly of a nation being "reborn." "The great American improvisation called democracy," George Packer enthusiastically observed, "still bends along the curve of history. It has not yet finished astounding the world" (Packer, 2008).

In this chapter, I discuss some of the implications of this study. First, I begin by analysing the future of neoconservatism in the Obama era. Second, I draw several conclusions from the arguments made in this thesis. The purpose of this thesis has been to define neoconservatism through the ideas and beliefs of its leading foreign policy intellectuals. Reflecting in an April 2003 article in The Weekly Standard,

\footnotetext{
${ }^{184}$ For two interesting studies that locate the problems of American national security deep within the institutions and structures of America's national security architecture, and America's culture of endless consumption, see Bacevich, 2005; and 2008a. For a book that is supportive of the Bush Doctrine, and predicts that it will outlive its original authors, see Lynch \& Singh, 2008.
} 
Irving Kristol maintained that neoconservatism was something "whose meaning we clearly glimpse only in retrospect" (Kristol, 2003). With the passing of the Bush presidency, it is as relevant now as it ever has been to continue thinking about how neoconservatism should be defined. By defining it through the ideas and beliefs of its leading foreign policy intellectuals, one develops not only a refined understanding of the neoconservative approach to American foreign policy, but also an historical awareness of some of the most significant foreign policy debates that have taken place in America over the past several decades.

After a brief discussion explaining how neoconservatives have gone about reorganising themselves in the Obama era, the chapter revisits the neoconservative attempt to protect the national idea, the idea that governments are instituted to secure the rights of the governed. This idea remains a very valuable idea, one worthy of a spirited defence. Yet enlisting its aid in ideological crusades against totalitarian enemies, I argue, is fraught with national risk and peril.

The chapter then re-examines neoconservative ideas and beliefs on American power. The global financial crisis which came to the world's attention in 2008 suggests that "order" in the modern world must be thought about in a more nuanced way than it has been in the past. Yet even in the midst of what has been a destabilising global financial crisis, America retains a unique position in the international system. There is nothing inherently wrong, I argue, with seeking to perpetuate American military preponderance. This, however, does not require America to discourage the rise of other independent poles of power. Europe may or may not begin to play a more dominant role in the world, but its rise should neither be discouraged nor feared. The chapter concludes by returning to the war in Iraq. If this is the conflict that neoconservative ideas will forever be attached to, whether rightly or wrongly, it seems reasonable to conclude that the fate of neoconservatism is in some small way tied to the outcome of this war.

\section{The Future of Neoconservatism}

In 2006, The Project for a New American Century was formally dissolved. By the start of 2009, however, a time when many were celebrating neoconservatism's perceived passing, William Kristol, Robert Kagan, and Dan Senor, established the 
Foreign Policy Initiative (FPI), another neoconservative think tank. On the opening page of the think-tank's website, the founders state their aims:

In 2009 the United States - and its democratic allies - face many foreign policy challenges. They come from rising and resurgent powers, including China and Russia. They come from rogue states that work with each other in ways inimical to our interests and principles, and that sponsor terrorism and pursue weapons of mass destruction. They come from al-Qaeda and its affiliates who continue to plot attacks against the United States and our allies. They come from failed states that serve as havens for terrorists and criminals and spread instability to their neighbours (The Foreign Policy Initiative Mission Statement, 2009).

It added:

In this new era, the consequences of failure and the risks of retreat would be even greater than before. The challenges we face require $21^{\text {st }}$ century strategies and tactics based on a renewed commitment to American leadership. The United States remains the world's indispensable nation - indispensable to international peace, security, and stability, and indispensable to safe-guarding and advancing the ideals and principles we hold dear (The Foreign Policy Initiative Mission Statement, 2009).

The FPI held its first major conference in April 2009 entitled "Planning for Success," a conference in which America's military strategy in Afghanistan was debated. It was a conference in which many of the participants, including Robert and Frederick Kagan, and John McCain, expressed their general agreement with the Obama administration's decision to deploy an additional 21,000 troops to Afghanistan, the goal of which is to suppress the worsening insurgency destabilising the country.

Even at a time when most of the world has begun to settle into the Obama era, neoconservatives are reorganising, preparing for the future. They may know that much of the world does not hold them in high regard, but that is not the point. If neoconservatives were influential after September 11, it was because they spent the better part of a decade preparing answers to questions which Americans only began to 
ask after al-Qaeda struck. "Every crisis for neoconservatism," Michael Dougherty argues when emphasising the disrepute into which neoconservatism has fell, "is just a new opportunity" (Dougherty, 2009). No challenge is insurmountable and no revisions are considered necessary. Their time will once again come, they believe, so they best begin preparing for the future.

Neoconservatives are bound to have an ambivalent relationship with the administration of Barack Obama. Charles Krauthammer is arguably the sharpest neoconservative critic of Obama. In an op-ed entitled "Who Does He Think He Is" (2008), Krauthammer strongly questioned his credentials to be President:

As president of the Harvard Law Review, as law professor and as legislator, has he ever produced a notable piece of scholarship? Written a single memorable article? His most memorable work is a biography of his favourite subject: himself (Krauthammer, 2008)

When it comes to foreign policy, Krauthammer sees Obama as too inexperienced, too willing to accommodate hostile powers, and too eager to ask for the world's forgiveness for a litany of American misdeeds, real and imagined. "It's Your Country Too, Mr President," Krauthammer advised Obama in the title of one of his articles written after the 2009 G20 London Summit. "With varying degrees of directness or obliqueness," Krauthammer complained, "Obama indicted his own people for arrogance, for dismissiveness and derisiveness, for genocide, for torture, for Hiroshima, for Guantanamo, and for insufficient respect for the Muslim world" (Krauthammer, 2009). While some neoconservatives have reached out to the Obama administration, Krauthammer is not one of them.

In the 2008 election campaign, Barack Obama promoted an idealistic vision of what America's role in the world should be, claiming, "We can neither retreat from the world nor try to bully it into submission. We must lead the world, by deed and by example" (Obama, 2007). Notwithstanding Krauthammer's hostility, such sentiments led to a paroxysm of joy among some neoconservatives. "Obama believes the world yearns to follow us, if only we restore our worthiness to lead," Robert Kagan rejoiced. "Personally, I like it" (Kagan, 2007b). Obama's idealism, according to Kagan, "put an end to the idea that the alleged overexuberant idealism and American-centrichubris of the past six years is about to give way to a new realism" (Kagan, 2007b). 
In the American Conservative, the magazine launched by Patrick Buchanan, Jacob Heilbrunn authored a piece on the eve of Obama's inauguration, asking, "Where Have all the Neocons Gone" (2008). Taking note of the quotation cited above, neoconservatives, according to Heilbrunn, have begun to splinter, some remaining GOP devotees, others moving back towards the Democratic Party. Noting that even The Weekly Standard has published articles supportive of Hillary Clinton and her appointment as Secretary of State, Heilbrunn concludes, "Perhaps reaching out to the Obama administration will help rejuvenate neoconservatism. It could prove to be a more comfortable fit than either side might anticipate" (Heilbrunn, 2008).

Of course, as most of these writers would concede, it is a little premature to predict how neoconservatives will respond to the Obama administration. Suggestions that they are returning to their Democratic roots are more than a little questionable. As was the case with President Clinton and as was the case in many ways with President Bush, neoconservatives are quick to turn on a sitting President. It does not matter whether the incumbent is a Democrat or a Republican; neoconservatives are quick to distance themselves from the leadership of either party when they feel slighted. Their only real commitment is to their ideas and beliefs. The establishment of the FPI certainly shows that neoconservatives remain intent on having their voices heard. Whether anyone will listen is a different question.

\section{The War of Ideology and the National Idea of America}

There has always been an odd relationship between neoconservatism and liberalism in the realm of American foreign policy. It is worth re-emphasising this relationship, if only to show the degree to which neoconservative ideas and beliefs are rooted in American political culture. As I suggested in Chapter 3, there was an ideational convergence in the 1990s between neoconservatives and liberal hawks who wished to see America employ its power to end the decade's genocides and ethnic violence, especially in the Balkans. Both neoconservatives and liberal hawks consider themselves stalwart defenders of the national idea, custodians of the values that make America unique.

Liberal hawks, in fact, share with neoconservatives the same ideological combativeness that encouraged America's engagement in Iraq. Throughout the Bush era, liberals such as Paul Berman and Peter Beinart attempted to revive the anti- 
totalitarianism associated with the disparate group of liberal intellectuals who, following the defeat of Hitler, warned of the perils of Soviet totalitarianism and conducted the struggle against Stalinism. In an accurate summary of the challenge Berman sets himself in Terror and Liberalism, Tony Smith argues,

The challenge for Berman is to rally the democratic world to the struggle against a new form of evil manifest in the terrorism of the Middle East, whether it be of the religious sort that has struck Israel, Russia, the United States and in places in Western Europe (not to speak of it acting internally within the Middle East), or of the sort wherein despots like Saddam subject their own populations to exactions rare in the annals of human history (Smith, 2007: 218).

Whereas Berman's Terror and Liberalism (2004) spends more time tracing the roots of the ideas which allegedly led to the embrace of martyrdom among Islamic jihadists, locating them in radical nineteenth European ideologies which glorified murder and suicide, Beinart's The Good Fight: Why Liberals - and Only Liberals Can Win the War on Terror and Make America Great Again (2006), is a manifesto summoning liberals to restore America's lost greatness. America must never assume its greatness, according to Beinart. "In the liberal vision," he declares, "national greatness is not inherited and it is not declared; it is earned" (Beinart, 2006: 207). In other words, only a constant striving towards greatness, defined as living up to American ideals at home, listening to the advice of allies, and combating evils abroad, of which Islamic totalitarianism is the most prominent, can restore America's reputation for good in the world.

The arguments of Beinart and Berman, both of whom consider themselves men of the left, reinforce the importance of neoconservatism. Their arguments do not diverge as much from the arguments of neoconservatives as Beinart and Berman assume. Beinart may talk about the importance of courting allies, but as David Rieff has argued, the difference is one of "Tone, not substance" (Rieff, 2006: 167). Liberal interventionists speak frequently about the importance of international law and ad hoc tribunals, but international law does not remove violent regimes and ad hoc tribunals 
do not do much for those suffering in the present. ${ }^{185}$ "The answer," Rieff argues when discussing how humanitarian war hawks responded to the international community's inability to end the horrors of the 1990s,

was to harness American military power, power the likes of which the world had never seen, to this noble cause of protecting the victims of genocide and mass slaughter, securing people's liberties, and spreading - call it what you will - open societies, democracy, liberal capitalism. For once one has accepted the premise that military power has to be used, there is no real alternative to U.S. military power (Rieff, 2006: 162)

The arguments of these self-identified liberals are important because they reflect the degree to which some of these ideas and beliefs inhere in American political culture. Writers on neoconservatism, with greater and lesser degrees of validity, stress the importance of a Jewish mindset, but such arguments imply that once neoconservative influence wanes, as it has in the Obama era, America will no longer have to concern itself with the crusading messianism of the Bush years. Yet the potential for ideological crusades has always been an ever present possibility in the United States. In The Liberal Tradition in America (1955), Louis Hartz warned, “An absolute national morality is inspired either to withdraw from 'alien' things or to transform them: it cannot live in comfort constantly by their side" (Hartz, 1955: 286).

Foreign policy realists have always noted the possibility of a dormant messianism reasserting itself in times when national anxieties are acute. Anatol Lieven argues, "the deeper tendencies in American political culture which the neoconservatives exploited will remain" (Lieven, 2004: 153). It is not that realists do not find something of great value in American ideals and values, for most, including Lieven, recognise that liberalism has great merits. What they fear is the ideological crusade wherein compromise is considered appeasement, wherein negotiation is considered morally corrupting, and wherein caution is considered a form of national cowardice.

Neoconservatives not only advocate ideological crusades; they relish them. Throughout the Cold War, neoconservatives completely overlooked the impact that

\footnotetext{
${ }^{185}$ Beinart himself recognises this, arguing, "America could not have built schools for Afghan girls had it not bombed the Taliban first. And efforts to aid the people of Sarajevo were largely fruitless until NATO air strikes broke the Serbian siege" (Beinart, 2006: 197).
} 
leaders can have on history, dismissing such arguments as outdated and antiquated notions believed only by those who subscribe to the "discredited" Great Man theory of history. Nations, they argued, were driven by their quest for power, their great power ambitions, and their ideological dictates. Nothing in their belief system and in their ideas could have prepared them for the arrival of Mikhail Gorbachev and Ronald Reagan. Nothing, in other words, could have prepared them for the end of the Cold War and the way in which it was ended.

When it came to the war on terror, the primacy of ideology in neoconservative thinking led them to become the natural champions of democratising the Middle East. Echoing liberal hawks and extracting several ideas from IR scholarship, they championed the need to ideologically transform a region they considered to be mired in fundamentalist bigotry. Yet the need to wage an ideological war in the Middle East was always overstated. As Fareed Zakaria argues, "no society looks with admiration and envy on the fundamentalist Islamic model" (Zakaria, 2008: 14). Attempting to militarily democratise a region within which the terror threat does not primarily emanate is more than a little questionable. It obscured the threat America faced and continues to face.

Of course, America will never be able to entirely de-ideologize its foreign policy. American ideals and values have always played a role in the nation's foreign policy. In a statement Robert Kagan would certainly endorse, Anne Marie Slaughter accurately argues, "Democracy and liberty are deeply intertwined in our history and our national identity as Americans" (Slaughter, 2007: 65). But there is a distinction between having faith in a set of principles and wishing to see those principles militarily imposed on other national societies. The former is produced by a natural and healthy attachment to the values of one's country; the latter is a result of an ideological militancy which has not served America well, especially in Iraq. There will always be a danger that America will succumb to the temptation to crusade abroad for its values. America's desire to liberalise the world can never be eliminated. But the challenge is to find a way to channel the desire through avenues capable of satisfying America's idealism without leading to ideological crusades which consume thousands of American lives.

There is also a danger that, at least in the short term, foreign policy-makers and intellectuals will begin to argue that American values should have a more limited role to play in the formation of the nation's foreign policy. Can America not return to the 
Nixon-Kissinger era of détente, an era in which, whatever their personal flaws, these two men engaged in the sophisticated diplomacy needed to combat the perils of a very complex multipolar world? America, though, has always proved resistant to Kissinger's brand of statecraft and for good reason. If there are dangers inhering within the neoconservative war of ideology, there are just as many dangers inhering within the idea that governments should be able to govern in any way they deem appropriate. As Suzanne Katzenstein and Jack Snyder argue in an important article which calls on policy-makers to rethink the way in which America can advance human rights, "being realistic does not mean that states should be left alone to do whatever they want to their citizens" (Katzenstein \& Snyder, 2009: 59). There must be a continuing debate on what America can do to advance human rights in the world, a debate which Katzenstein and Snyder will hopefully spark. ${ }^{186}$ America, after all, will always need a moral purpose both to satisfy the nation's own idealism and to respond to the needs of a world which, whatever its complaints, by and large believes in the American promise.

So while American foreign policy may require a salutary administering of realism in the coming years, it cannot and should not lead America to overlook the many examples of oppression in the world. Advancing human rights around the globe requires a considerable amount of international cooperation, among states, among international and regional institutions, and among a plethora of NGOs; ${ }^{187}$ it may even require taking the United Nations seriously, viewing it as a partner to be enlisted in a noble cause, not an ideological adversary committed only to providing a forum in which a constellation of petty tyrannies can air their extravagant complaints. Whether neoconservatives are capable of such a feat is doubtful. Krauthammer continues to call the United Nations "a fiction and a farce" (Krauthammer, 2009).

The United Nations is an international institution whose failures need not be catalogued here, for anyone who lived through the 1990s would have an appreciation of them - there is, of course, less appreciation of its successes. ${ }^{188}$ Notwithstanding its

\footnotetext{
${ }^{186}$ The article by Suzanne Katzenstein and Jack Snyder, "Expediency of the Angels" (2009), questions the traditional methods employed to advance human rights, which have traditionally centred upon "naming and shaming" human rights abusers and encouraging states to sign treaties which supposedly "obligate" signatories to end such abuses. They advance a number of other more pragmatic methods said to yield more fruitful results. See Katzenstein and Snyder, 2009.

${ }^{187}$ For an excellent look at democracy promotion strategies which contrasts the European and American approaches, see Carothers, 2009.

${ }^{188}$ For one of the most balanced appraisals of the United Nations which emphasises its failures and successes, see Kennedy, 2007.
} 
failures, America and the United Nations should work together to advance the international human rights regime along with democratic standards of governance. Neoconservatives will more than likely dismiss such an argument as nonsensical. But such dismissals overlook the collective achievements of both America and the United Nations in already advancing the human rights regime, one which has come a long way since the Nazi holocaust, the event of the twentieth century which did so much to galvanise human rights activists around the world. ${ }^{189}$ It was, after all, President Truman who appointed Eleanor Roosevelt to head the United Nations commission which produced the Universal Declaration of Human Rights. 190 "Thus, despite all the setbacks and ghastly actions," Paul Kennedy argues,

there has been a bigger advance in the idea and practice of national and international human rights in the past sixty years than in any comparable period in all of history. The gap between the rights enjoyed by a citizen of Sweden and those granted a citizen of Sudan at present is still far too wide. But the point is that we all know about that, and that there is a collective world effort to close the gap (Kennedy, 2007: 204).

Currently, there is also an emerging literature which is attempting to rescue the good name of "democracy promotion," a name very much tarnished by its association with the Bush administration's forceful democratisation project in Iraq. ${ }^{191}$ Standing up for principles of democratic governance is an intrinsic part of America's national character and cannot be de-linked from human rights concerns. Daniel Patrick Moynihan was right when he argued that Americans must never go down a less idealistic road "at the behest of men who know too much to believe anything in particular and opt instead for accommodations of reasonableness and urbanity that drain our world position of moral purpose" (Moynihan, 1974: 29). But faith in democracy should never lead to the crusading messianism on display in the lead up to the 2003 Iraq War. In future years, America must cultivate a sense of national detachment which sees problems for what they are, knowing that there will always be

\footnotetext{
${ }^{189}$ For a good examination on the evolution of the human rights regime following World War Two, see Sikkink, 1993.

${ }^{190}$ For the definitive account of Eleanor Roosevelt's time on this commission, see Glendon, 2002.

${ }^{191}$ For an introduction to the work of some thinkers who wish to see democracy promotion remain a prominent goal of American foreign policy, albeit through employing methods very much at odds with the methods employed by the Bush administration, see Diamond, 2008; and Traub, 2008.
} 
a possibility that the nation's foreign policy will be beset by a moment of ideological excess. All nations, though, must learn to live with their creedal dangers. The real future challenge will be to recognise neoconservatives for what they are: the most dedicated group of ideologists America has arguably produced.

\section{$\underline{\text { Neoconservatism, American Preponderance, and Great Power War }}$}

If neoconservatives are to be defined by their attempt to protect the national idea of America and their desire to wage a war on behalf of liberal democracy, then they must also be defined by their ideas on American power. Whatever order exists in the world today, neoconservatives frequently argue, must be attributed to the role America plays in the world, and more specifically, the role American power plays in the world. Yet as international leaders attempt to overcome the global financial crisis which has dominated headlines around the world since the end of 2008, a number of conclusions can be drawn and a number of debates have been renewed. First, the crisis suggests that the idea of "order" itself is not as clear as IR scholarship has assumed, for global financial crises, while not on par with the outbreak of great power war, are more than a little unsettling. As IR theorists and neoconservatives debated if other states would balance the American hegemon, the global financial system was headed towards an implosion from which it will take years to recover.

The debates the crisis has sparked will undoubtedly take their cues from a number of sources, the most prominent of which will be Fareed Zakaria's The Post-American World (2008). Although some of Zakaria's upbeat assessments of the global economy may have been revised had the book not been published just before the crisis became most visibly acute, it is a volume in which Zakaria makes an argument that will no doubt be echoed in a number of quarters. "We are now living through the third great power shift of the modern era," he argues.

It could be called 'the rise of the rest.' Over the past few decades, countries all over the world have been experiencing rates of economic growth that were once unthinkable. While they have had booms and busts, the overall trend has been unambiguously upward. This growth has been most visible in Asia but is no longer confined to it (Zakaria, 2008: 2). 
Other IR scholars are less convinced. Robert Lieber, Professor of International Relations at Georgetown University in Washington D.C., authored two articles in World Affairs and International Politics, respectively entitled "Falling Upwards: Declinism, the Box Set" (2008), and "Persistent Primacy and the future of the American Era" (2009). Along with William Wohlforth and Stephen Brooks, Lieber remains one of the more perceptive IR scholars on American primacy and its capacity to sustain itself. "Of course, present problems are very serious," Lieber acknowledges in the latter article cited above,

and the financial crisis is the worst to hit the United States and Europe since the great depression began some 80 years ago. The impact on real estate, banking, insurance, credit, the stock market and overall business activity is quite severe, and a painful recession is already under way. Yet by themselves these developments do not mean that America will somehow collapse, let alone see some other country assume the unique role it has played in world affairs (Lieber, 2009: 135).

Wohlforth and Brooks also re-entered the fray, releasing a volume entitled World Out of Balance: International Relations and the Challenge of American Primacy (2008). In this volume, the authors survey all the dominant theories of International Relations and find all the theories flawed. Representatives from each theoretical paradigm, according to these thinkers, overstate the constraints America faces in the world. What the 1992 Defense Planning Guidance and 1993 Regional Defense Strategy recommended, according to the analysis of this impressive study, has been achieved. America has transformed the "unipolar moment" into a "unipolar era" which shows no signs of passing. "The balancing constraint may well work on the leading state up to a threshold of hegemony or unipolarity," Wohlforth and Brooks argue in one chapter assessing the reason why no other state has balanced the American hegemon.

Once a state passes this threshold, however, the causal arrows reverse: the stronger the leading state is and the more entrenched its dominance, the more improbable and thus less constraining counterbalancing dynamics are. (Brooks \& Wohlforth, 2008: 48). 
That America retains a very unique position in the international system cannot be doubted. Even Zakaria, while viewing power in a multidimensional way, accepts that "At the politico-military level, we remain in a single superpower world" (Zakaria, 2008: 4). What this means for neoconservatives is open to debate. In the military sphere, the world is a long way from becoming multipolar. If Lieber, Brooks, and Wohlforth are right, then America will retain a preponderance of military power which has not been matched throughout the course of human history.

So what about the prospects of great power war? This is the question which has driven so many neoconservatives, especially but by no means exclusively Paul Wolfowitz. For neoconservatives, order, defined as the absence of great power war, is a key value. "It would be a great mistake," Paul Wolfowitz once warned,

To take stability in the Asia-Pacific region for granted. If one includes India, the seven largest military forces in the world operate in this region. Every one of those armies has been at war in Asia at some time since World War II. Practically every pair of neighbours in this part of the world has some historical, ethnic, or territorial basis for conflict. It will take continued skilful diplomacy to preserve peace and stability. But that diplomacy also needs to be supported by adequate strength in the hands of those who seek to preserve peace (Wolfowitz, 1991: 238239).

Here, then, is the greatest justification among neoconservatives for perpetuating America's military preponderance, a justification, I showed in Chapter 5, finding its clearest expression in the strategic documents drafted and released in the early 1990s. Without an American goliath, to use Michael Mandelbaum's terminology, chaos will reign. Without an America willing to extend protection to every country around the world, security policies will be renationalised and great power war will ensue. The logic is encapsulated in Robert Kagan's The Return of History and the End of Dreams (2008). "In a world heading toward a more perfect liberal order, an old-fashioned superpower with a sense of global mission might seem a relic of the past and an obstacle to progress," Kagan argues when referring to America's sense of its role in the world. "But in a world poised precariously at the edge of a new time of turmoil," he asks, "might not even a flawed democratic superpower have an important, even indispensable, role to play?" (Kagan, 2008: 86). For Kagan, it most certainly does. 
Much has been made, I explained, about the importance neoconservatives attach to the character of regimes. But the importance attached to the character of regimes is more a consequence of ideology than reasoned analysis. Kagan may insist that "True realism about international affairs means understanding that a nation's foreign policy is heavily shaped by the nature of its government," but his own analysis of the behaviour of great powers challenges this argument (Kagan, 2008: 98). In the same volume from which this quotation was taken, Kagan argues, "International relations theorists talk about 'status quo' powers, but nations are never entirely satisfied. When one horizon has been crossed, a new horizon always beckons" (Kagan, 2008: 17). This is as true for democracies such as India and Japan, Kagan's volume makes clear, as it is for the autocracies of Russia and China. All nations, according to Kagan, have their ambitions, all nations struggle for power, and war among nations is an ever present possibility. For Kagan, the character of regimes may intensify the struggle for power, but it certainly does not create it.

Regardless of whether it was the ideological strivings of a rival superpower throughout the Cold War or the potential of the world to revert back to a period of "destabilising" multipolarity, neoconservatives became ardent defenders of the need for a strong America. Throughout the Cold War, they saw America engaged in a titanic struggle against a rival ideological superpower. Throughout the 1990s, to the extent that neoconservatives continued to emphasise the importance of democracy promotion, they did so because of their ideological sense of what America should be standing for in the world. More pronounced throughout this period was the emphasis placed on the dangers of multipolarity. Whatever the threat, whatever the era, only the American hegemon stood in the way of global disorder. As such, all other potential poles of power in the international system needed to be kept weak and in a state of permanent dependence. To this day, neoconservatives still question the need for modest cuts in the defence budget (see Kagan, 2009).

The quest to perpetuate America's military preponderance is a core component of the neoconservative approach to American foreign policy, one which must feature in any attempt to understand neoconservatism through the ideas and beliefs of its leading foreign policy intellectuals. Of course, America must continue to accept that the world is a dangerous place, comprised of multifarious threats, of which terrorism remains more prominent than some may assume. Also, Kagan's warnings of a return of great power conflict cannot be discounted. Aggressive regimes may indeed be a 
fixture in world politics. Enough has been written about the reappearance of great power autocracies to suggest that the era of great power competition is not over. ${ }^{192}$ One can certainly hope that the liberal internationalist project of entangling these powers within the international system, giving them a stake in its stability, will be successful. With one of the most popular presidents since Woodrow Wilson, America has a valuable asset capable of repairing and rebuilding America's alliances, alliances whose members should be enlisted in common causes.

But America must always be prepared for unforeseen challenges and it must remain strong enough to meet them. The prospects of great power war are slim, but they are not nil. Nations still have interests they would go to war over. It is hard to disagree with Kagan when he argues that "Taiwan could be the Sarajevo of the SinoAmerican confrontation" (Kagan, 2008: 36). A number of China experts agree with this conclusion. ${ }^{193}$ As Susan Shirk argues, "Interdependence breeds caution, but it doesn't guarantee peace" (Shirk, 2008: 34). Of course, nothing is inevitable, a truism Kagan would certainly endorse. A world centred upon American primacy and military preponderance is still a good thing. When David Fromkin wrote his brilliant volume on the origins of World War One, Europe's Last Summer: Who Started the Great War in 1914 (2005), he reflected on the lessons of the war. "It was no accident that Europe went to war at that time," he argues. "It was the result of premeditated decisions by two governments," the governments of Germany and Austria-Hungary (Fromkin, 2005: 293). Ruminating on the prospects of a similar war in the future, Fromkin discussed the precariousness of peace among nations, arguing, "An aggressor can start a major war even today and even if other great powers desire to stay at peace - unless other nations are powerful enough to deter it" (emphasis added) (Fromkin, 2005: 293-294). Sage advice, one could argue.

\section{$\underline{\text { Neoconservatism and American Power }}$}

When the Foreign Policy Initiative held its first conference on battlefield strategy in Afghanistan in April 2009, absent from the discussion, a transcript of which can be accessed at the FPI website, was any assessment of the lessons America should have learned over the past several years in relation to the limits of American power. There

\footnotetext{
192 In addition to Kagan's volume, see Gat, 2007.

${ }^{193}$ For a good discussion on the question of Taiwan and U.S. foreign policy, see Carpenter, 2005.
} 
was to be no recognition of the failure of the ideas promoted throughout the Bush era, and no re-visiting of the idea of preventive war. In chapter 6 , I argued that neoconservatism must be defined in part by its views on the employment of American power. That the first conference of the FPI was being held on Afghanistan was more than a little ironic. Neoconservatives had shown little concern for the fate of this country when they were advocating going to war against Iraq in the immediate aftermath of September 11. According to Michael Dougherty, an observer at the conference, upon arriving members of the crowd were given a copy of an article, one of the authors of which was Max Boot, which outlined what America needed to do to prevail in Afghanistan. ${ }^{194}$ Boot, though, was an odd source to turn to when it was he who in 2001 made the following argument:

Once Afghanistan has been dealt with, America should turn its attention to Iraq. It will probably not be possible to remove Saddam quickly without a U.S. invasion and occupation - though it will hardly require half a million men, since Saddam's army is much diminished since the Gulf War, and we will probably have plenty of help from Iraqis, once they trust that we intend to finish the job this time. Once we have deposed Saddam, we can impose an American-led, international regency in Baghdad, to go along with the one in Kabul. With American seriousness and credibility thus restored, we will enjoy fruitful cooperation from the region's many opportunists, who will show a newfound eagerness to be helpful in our larger task of rolling up the international terror network that threaten us (Boot, 2001).

It is hard to find a more confident assertion of what American power was poised to achieve in the world. Afghanistan may have been important, but it was never as important as Iraq. Neither conflict was expected to be overly difficult. "According to one estimate," William Kristol and Lawrence Kaplan argued when making the case for war in Iraq (they did not cite the estimate),

initially as many as 75,000 U.S. troops may be required to police the war's aftermath, at a cost of $\$ 16$ billion a year. As other countries' forces arrive, and as

\footnotetext{
${ }^{194}$ The article had actually been published in a recent edition of The Weekly Standard. See Boot, Kagan, \& Kagan, 2009.
} 
Iraq rebuilds its economy and political system, that force could probably be drawn down to several thousand soldiers after a year or two (Kristol \& Kaplan, 2003: 98).

These words are invoked not to embarrass their authors, but to spotlight a degree of faith in American power that has had very negative results for American foreign policy. It was a degree of faith in American power that virtually all neoconservatives shared. After the terrorist attacks on September 11, going to war in Afghanistan was just and right. Indeed, it would be hard to imagine a more just war being fought in one's lifetime than the one fought against the Taliban and al-Qaeda.

No serious observer, however, could dispute that the transfer of military resources from Afghanistan to Iraq led to the problems in Afghanistan that neoconservatives now propose to solve. "Time and again," argues David Sanger,

Afghanistan - the country where the 9/11 plot was hatched - was overshadowed by the war in Iraq. Early successes had made it easier to ignore the deepening challenges as the conflict wore on. As resources shifted west, toward Baghdad, plans for a robust reconstruction program evaporated. The initial appearance of an easy victory was masked by the fact that the Taliban had never been defeated, but simply had moved across the border into the safety of the tribal areas in Pakistan (Sanger, 2009: 118).

The decision, moreover, to focus on Iraq convinced the Pakistani dictator, Pervez Musharraf, that Pakistan could safely wait out America's war in Afghanistan. Having supported the Taliban, indeed having created the Taliban by educating its leaders in the country's ubiquitous religious schools, Musharraf knew that Pakistan could resume its support for the Taliban once American forces had withdrawn from the country. As it turned out, in fact, this support was extended as soon as it was made clear that America's priorities lied elsewhere. As Ahmed Rashid, one of the most perceptive intellectuals on Central Asia, argues,

the U.S. attack on Iraq was critical to convincing Musharraf that the United States was not serious about stabilising the region, and that it was safer for Pakistan to 
preserve its own national interest by clandestinely giving the Taliban refuge (Rashid, 2008: xli).

The Taliban, in other words, were allowed to reconstitute and so was al-Qaeda. Al-Qaeda, to this day, remains a security threat, one that is very real but not easily defined. Scholars of international terrorism must continue to analyse how the leadership of al-Qaeda, located in Western Pakistan, appeals to and recruits alienated Muslim youths living in the West. What are the overlapping connections? Are there any? Or is the threat now posed by "lone wolf" terrorists living in the West who have little contact with those residing in Pakistan and Afghanistan? What can be done to infiltrate terrorist networks? How can another September 11 be prevented? How do you define success in Afghanistan? These are not the grand ideological questions neoconservatives enjoy answering. But they are the important questions needing to be asked. ${ }^{195}$ America's future security depends on sober responses.

Neoconservatives, I argued, must be defined in part by their ideas on the employment of American power, including the idea of preventive war. This was the idea that was the capstone of neoconservative thinking on the transformative potential of American power. Of course, America's military might will always have a role to play in world affairs, especially against al-Qaeda. However, whether that role should be defined by an intellectual community who became so heedless in calling for its employment is contestable in the extreme.

Neoconservatives will certainly continue to make their voices heard. The establishment of the FPI will be a dominant forum in which ideas can be circulated and contacts made. Neoconservatives are now emphasising many different threats, from the return of autocratic powers to Iran's pursuit of nuclear weapons to the ailing security situation in Afghanistan. Often overlooked is Iraq. "While American troops remain stuck in Iraq," Andrew Bacevich caustically concludes when reviewing Robert Kagan's A Return to History and the End of Dreams, "Kagan is moving on to other things" (Bacevich, 2008). The surge in Iraq certainly turned around the country's fortunes. Those neoconservatives who insisted that more American troops be deployed do deserve a small portion of credit. Yet not even the "success" of the surge should be considered enough to restore any measure of trust in the leading intellectual

\footnotetext{
${ }^{195}$ For one of the more recent studies assessing the future of al-Qaeda and how to defeat it, see Riedel, 2008.
} 
proponents of the Iraq War. At the time of writing, there are still suicide bombings in Iraq, bombings which are killing dozens of civilians. The war itself is far from complete. In the last sentence of his second volume on the Iraq conflict, Thomas Ricks concludes, "the events for which the Iraq war will be remembered probably have not yet happened" (Ricks, 2009: 325). However, as history continues to unfold in Iraq, it is not only Kagan who has moved on to other things. So has neoconservatism.

\section{$\underline{\text { Conclusion }}$}

This thesis has defined neoconservatism through the ideas and beliefs of its leading foreign policy intellectuals. There is a continuing narrative being written on neoconservatism, one encompassing a variety of different approaches. Such a narrative should continue to be written, for neoconservatives remain a fascinating intellectual community dedicated to a life of ideas. This thesis has attempted to make a small contribution to this narrative. Neoconservatism will always be linked to Iraq, as well it should. But there is more to the neoconservative approach to American foreign policy than Iraq. Neoconservative ideas and beliefs needed to be placed side by side and analysed collectively. Such an approach, I believed, would illuminate the neoconservative approach to American foreign policy, capturing elements of neoconservatism which have escaped the attention of other authors and scholars. That was the purpose of this thesis.

Protecting the national idea, waging the war of ideology, perpetuating America's military preponderance, and wielding American power, these are the ideas and beliefs which should define neoconservatism. Francis Fukuyama may or may not have been right when he suggested that neoconservatism is beyond repair. But for neoconservatives, the mission is never accomplished. There are too many dangers to rest on one's laurels. "The failure of the United States to take risks, and to take responsibility, in the 1990s," Kagan and Kristol argued before the 2003 Iraq War began, "paved the way to September 11" (Kagan \& Kristol, 2002). "It is a tough and dangerous decision to send American soldiers to fight and possibly die in Iraq," they acknowledged in this article. "But it is more horrible to watch men and women leap to their deaths from flaming skyscrapers. If we fail to address the grave threats we 
know exist, what will we tell the families of future victims. That we were 'prudent?'" (Kagan \& Kristol, 2002).

When I interviewed Kristol in 2007, he explained that the lesson to be taken from Iraq was not to refrain from tasks in the world that would be difficult and cumbersome, but to acknowledge their difficulty and gird oneself for the upcoming troubles and burdens (Kristol, interview, 21 February 2007). Prudence was still not a priority; resolve was. The lessons neoconservatives derive from America's experience in Iraq, though, may not be as relevant and as important as the lessons the American people derive. Will the war, the outcome of which is still uncertain and must await final evaluation, be remembered as a war which was poorly prosecuted but fundamentally sound in the ideas that led America there? Or will it be considered a war fought on questionable ideas and doctrines, conceived and justified in thinktanks, offices, and in the minds of those who dedicate themselves to living a life in which ideas are everything. "It is not often that nations learn from the past," Henry Kissinger once argued, "even rarer that they draw the correct conclusion from it" (Kissinger, 1964: 321). Whether this will be applicable when it comes to evaluating America's future conduct in the aftermath of Iraq only time will tell. The choice, as always, is a choice only America can make. 


\section{List of References}

Abelson, Donald. (2006) A Capitol Idea: Think Tanks \& US Foreign Policy. Montreal and Kingston: McGill-Queen's University Press.

Al-Zayyat, Montasser. (2004) The Road to Al-Qaeda: The Story of Bin Laden's Right-Hand Man. London and Sterling: Pluto Press.

Anastaplo, George. (1999) 'Leo Strauss at the University of Chicago.' In K.

Deutsch and J. Murley (eds.) Leo Strauss, the Straussians, and the American Regime. Maryland: Rowman \& Littlefield.

Arendt, Hannah. (1951) The Origins of Totalitarianism. Orlando: Harcourt, Inc.

Aron, Raymond. (2003) Peace and War: A Theory of International Relations.

New Brunswick and London: Transaction Publishers. Originally published in 1966.

Art, Robert. (2003) A Grand Strategy for America. Ithaca and London. Cornell University Press.

Bacevich, Andrew. (2006) The New American Militarism: How Americans Are

Seduced by War. Oxford and New York: Oxford University Press.

Bacevich, Andrew. (2008a) The Limits of Power: The End of American

Exceptionalism. New York: Metropolitan Books.

Bacevich, Andrew. (2008b) 'Present at the Re-Creation,' Foreign Affairs, vol. 87, issue. 4 , pp. $125-131$.

Baldwin, David. (ed.) (1993) Neorealism and Neoliberalism: The Contemporary Debate: New York: Columbia University Press.

Beinart, Peter. (2006) The Good Fight: Why Liberals - and Only Liberals - Can

Win the War on Terror and Make America Great Again. New York: HarperCollins Publishers.

Beisner, Robert. (2006) Dean Acheson: A Life in the Cold War. Oxford and New York: Oxford University Press.

Bennett, William. (2003) Why We Fight: Moral Clarity and the War on

Terrorism. Washington, D.C.: Regnery Publishing.

Bergen, Peter. (2002) Holy War Inc.: Inside the Secret World of Osama bin

Laden. New York: Touchstone.

Bergen, Peter. (2006) The Osama bin Laden I Know. New York: Free Press.

Beschloss, Michael. (2003) The Conquerors: Roosevelt, Truman and the Destruction of Hitler's Germany. New York: Simon and Schuster. 
Berman, Paul. (2004) Terror and Liberalism. New York and London: W.W. Norton \& Company.

Bhagwati, Jagdish. (2004) In Defense of Globalisation. Oxford and New York: Oxford University Press.

Bin Laden, Osama. (1996) 'Bin Laden's Fatwa,' http://www.

Pbs.org/newshour/terrorism/international/fatwa_1996.html, Date accessed 09/12/2004.

Bin Laden, Osama. (1998) 'Jihad Against Jews and Crusaders,' http://www.fas.org/irp/world/para/docs/980223-fatwa.htm, Date accessed 09/12/2004.

Blitz, Mark. (2003) Leo Strauss, the Straussians and American foreign policy, www.openDemorcacy.net/democracy-americanpower/article_1577.jsp, Date accessed 27/04/07.

Bloom, Alexander. (1986) Prodigal Sons: The New York Intellectuals \& Their World. Oxford and New York: Oxford University Press.

Bloom, Allan. (1988) The Closing of the American Mind. New York: Simon \& Schuster.

Blyth, Mark. (2003) 'Structures Do Not Come with an Instruction Sheet:

Interests, Ideas, and Progress in Political Science,' Perspectives on Politics, vol. 1, no. 4 (December), pp. 695-706.

Bodansky, Yousef. (2001) Bin Laden: The Man Who Declared War On America. New York: Prima Publishing.

Boller, Paul. (2004) Presidential Campaigns: From George Washington to George W. Bush. Oxford and New York: Oxford University Press.

Bonney, Richard. (2004) Jihad: From Quran to bin Laden. Hampshire and New York: Palgrave Macmillan.

Boot, Max. (2001) 'The Case for American Empire,' The Weekly Standard, vol. 7, issue. 5, October 15.

Boot, Max. (2003a) The Savage Wars of Peace: Small Wars and the Rise of American Power. New York: Basic Books.

Boot, Max. (2003b) 'American Imperialism? No need to run away from the label,' http://usatoday.com/news/opinion/editorials/2003-05-05-boot_x.htm, Date accessed 13/05/2006.

Boot, Max. (2006a) War Made New: Technology, Warfare, and the Course of History. Gotham Books: New York. 
Boot, Max. (2006b) 'Radical Ideas for Iraq: The current strategy isn't working. We either need more troops or a lot fewer,' The Weekly Standard, http://www.weeklystandard.com/Content/Public/Articles/000/000/012/562miuqr.asp, Date accessed 14/01/2009.

Boot, Max. (2006c) 'Power for Good: Since the end of the Cold War America the Indispensable,' The Weekly Standard, vol. 11, issue. 28, April 10.

Boot, Max. (2008) 'We Are Winning. We Haven't Won,' The Weekly Standard, vol. 13, issue. 20, February 4.

Boot, Max and Kagan, Frederick and Kagan, Kimberly. (2009) 'Yes, We Can: In the 'graveyard of empires,' we are fighting a war we can win,' The Weekly Standard, vol. 14, issue. 6, March 23.

Boyer, Peter. (2006) 'Downfall: How Donald Rumsfeld reformed the Army and lost Iraq, The New Yorker, http://www.newyorker.com.archive/2006/11/20/061120fa_fact, Date accessed 03/03/2007.

Brands, H.W. (1998) What America Owes the World: The Struggle for the Soul of Foreign Policy. Cambridge and New York: Cambridge University Press.

Breslauer, George and Lebow, Richard. (2004) 'Leadership and the End of the Cold War: A Counterfactual Thought Experiment.' In R. Herrmann and R. Lebow (eds.) Ending the Cold War: Interpretations, Causation, and the Study of International Relations. New York: Palgrave Macmillan.

Brooks, Stephen and Wohlforth, William. (2002) 'American Primacy in Perspective,' Foreign Affairs, vol. 81, issue. 4, pp. 20-33.

Brooks, Stephen and Wohlforth, William. (2004) 'Economic Constraints and the Turn towards Superpower Cooperation in the 1980s.' In O. Njolstad (ed.) The Last Decade of the Cold War: From Conflict Escalation to Conflict Transformation. London and New York: Frank Cass.

Brooks, Stephen and Wohlforth, William. (2005) 'Hard Times for Soft Balancing,' International Security, vol. 30, no. 1 (Summer), pp. 72-108.

Brooks, Stephen and Wohlforth, William. (2008) World Out of Balance: International Relations and the Challenge of American Primacy. Princeton and Oxford: Princeton University Press.

Brown, Archie. (1997) The Gorbachev Factor. Oxford and New York: Oxford University Press. 
Brown, Michael and Lynn Jones, Sean and Miller, Steven. (eds.) (1996) Debating the Democratic Peace. Cambridge and Massachusetts: The MIT Press.

Buchanan, Patrick. (2002) A Republic, Not an Empire: Reclaiming America's Destiny. Washington, D.C.: Regnery Publishing.

Bull, Hedley. (1977) The Anarchical Society: A Study of Order in World Politics. London: Macmillan.

Burke, Jason. (2003) Al-Qaeda: Casting a Shadow of Terror. London: I.B. Tauris.

Bush, George W. (2002/2003) 'Remarks at West Point: 'New Threats Require New Thinking." In M. Sifry and C. Gerf (eds.) The Iraq War Reader: History, Documents, Opinions. New York: Simon and Schuster.

Byers, Michael. (2005) War Law. New York: Grove Press.

Cannon, Lou. (2000) President Reagan: The Role of a Lifetime. New York: Public Affairs.

Carothers, Thomas. (2009) 'Democracy Assistance: Political Vs. Developmental? Journal of Democracy, vol. 20, no. 1 (January), pp. 5-19.

Cassels, Alan. (1996) Ideology and International Relations in the Modern World. New York \& London: Routledge.

Chomsky, Noam. (2003) Hegemony or Survival: America's Quest for Global Dominance. Sydney: Allen and Unwin.

Choosing Victory: A Plan for Success in Iraq (2007) A Report of the Iraq Planning Group at the American Enterprise Institute, http://www.aei.org/paper/25396 Date accessed 12/07/2008.

Churchill, Winston. (1940/1996) 'We Shall Fight in the Fields and in the Streets.' In W. Bennett (ed.) The Book of Virtues: A Treasure of Great Moral Stories. New York: Simon and Schuster.

Cirincione, Joseph. (2008) Bomb Scare: The History and Future of Nuclear Weapons. New York: Columbia University Press.

Codevilla, Angelo. (1997) The Character of Nations: How Politics Makes and Breaks Prosperity, Family, and Civility. New York: Basic Books.

Coleman, Peter. (1989) The Liberal Conspiracy: The Congress for Cultural Freedom and the Struggle for the Mind of Postwar Europe. New York: The Free Press. 
Coll, Steve. (2008) The Bin Ladens: The Story of a Family and its Fortune. New York: Allen Lane.

Corbin, Jane. (2003) The Base: al-Qaeda and the Changing Face of Global Terror. London: Pocket Books.

Coughlin, Con. (2002) Saddam: The Secret Life. Basingstoke and Oxford: Macmillan.

Crockatt, Richard. (2006) 'Anti-Americanism and the Clash of Civilizations.' In B. O'Connor and M. Griffiths (eds.) the Rise of anti-Americanism. London and New York: Routledge.

Crocker, Bathsheba. (2004) 'Iraq, Going it Alone, Gone Wrong.' In R. Orr (ed.)

Winning the Peace: An American Strategy for Post-Conflict Reconstruction.

Washington, D.C.: The CSIS Press.

Dallek, Robert. (2007) Partners in Power: Nixon and Kissinger. New York: HarperCollins.

Delong-Bas, Natana. (2004) Wahhabi Islam: From Revival and Reform to Global Jihad. London and New York: I.B. Tauris.

Desch, Michael. (1998) 'Culture Clash: Assessing the Importance of Ideas in Security Studies,' International Security, vol. 23, no. 1 (Summer), pp. 141-170.

De Tocqueville, Alexis. (1835/2004) Democracy in America. Translated by Arthur Goldhammer. New York: The Library of America.

Deutsch, Kenneth. (1999) Leo Strauss, the Straussians, and the American Regime.' In K. Deutsch and J. Murley (eds.) Leo Strauss, the Straussians, and the American Regime. Maryland: Rowman and Littlefield.

Deutsch, Kenneth and Murley, John. (eds.) (1999) Leo Strauss, the Straussians, and the American Regime. Maryland: Rowman \& Littlefield.

Diamond, Sara. (1995) Roads to Dominion - Right Wing Movements and Political Power in the United States. New York: The Guilford Press.

Diamond, Larry. (2005) Squandered Victory: The American Occupation and the Bungled Effort to Bring Democracy to Iraq. New York: Times Books.

Digby, James and Martin, J.J. (1991) 'On Not Confusing Ourselves:

Contributions of the Wohlstetters to U.S. Strategy and Strategic Thought.' In A. Marshall, J. J. Martin, and H. Rowen (eds.) On Not Confusing Ourselves: Essays on National Security in Honor of Albert and Roberta Wohlstetter. Boulder, Colorado: Westview Press. 
Diggins, John P. (2007) Ronald Reagan: Fate, Freedom, and the Making of History. New York and London. W.W. Norton \& Company.

Dionne, E.J. (2004) Why Americans Hate Politics. New York: Simon \& Schuster. Second edition. Originally published in 1991.

Dobbins, James. (2006) 'Learning the Lessons of Iraq.' In F. Fukuyama (ed.) Nation Building: Beyond Afghanistan and Iraq (pp. 218-231). Baltimore: The Johns Hopkins University Press.

Dodge, Toby. (2007) 'The Causes of US Failure in Iraq,' Survival, vol. 49, no. 1 (Spring), pp. 85-106.

Donnelly, Jack. (2000) Realism and International Relations. Cambridge and New York: Cambridge University Press.

Doogue, Geraldine and Kirkwood, Peter. (2005) Tomorrow's Islam: Uniting ageold beliefs in a modern world. Sydney: ABC Books.

Dorman, Joseph. (2001) Arguing the World: the New York Intellectuals in their own words. Chicago: University of Chicago Press.

Dorrien, Gary. (1993) The Neoconservative Mind, Politics, Culture, and the War of Ideology. Philadelphia: Temple University Press.

Dorrien, Gary. (2004) Imperial Designs: Neoconservatism and the New Pax Americana. New York and London: Routledge.

Dougherty, Michael. (2009) 'Neoconned Again,' The American Conservative, April 20.

Doyle, Michael. (1996) 'Kant, Liberal Legacies, and Foreign Affairs.' In M. Brown and S. Lynn-Jones and S. Miller (eds.) Debating the Democratic Peace. Massachusetts: The MIT Press.

Draper, Theodore. (1974) 'Détente,' Commentary, June, pp. 25-47.

Draper, Theodore. (1976) 'Appeasement and Détente,' Commentary, February, pp. 27-38.

Drury, Shadia. (1997) Leo Strauss and the American Right. Basingstoke: Macmillan.

Drury, Shadia. (2005) The Political Ideas of Leo Strauss. New York: Palgrave Macmillan. Originally published in 1988.

Ehrman, John. (1995) Neoconservatism: Intellectuals and Foreign Affairs 19451994. New Haven: Yale University Press. 
Elshtain, Jeane B. (2003) Just War against Terror: The Burden of American Power in a Violent World. New York: Basic Books.

English, Robert. (1999) Russia and the Idea of the West: Gorbachev, Intellectuals, and the End of the Cold War. New York: Columbia University Press.

English, Robert. (2002) 'Power, Ideas, and new Evidence on the Cold War's End: A Reply to Brooks and Wohlforth,' International Security, vol. 26, no. 4 (Spring), p. 92.

Esposito, John. (2003) Unholy War: Terror in the Name of Islam. Oxford and New York: Oxford University Press.

Evangelista, Matthew. (2004) 'Turning Points in Arms Control.' In R. Herrmann and R. Lebow (eds.) Ending the Cold War: Interpretations, Causation, and the Study of International Relations. New York: Palgrave Macmillan.

Fallows, James. (1982) 'In Defense of an Offensive War,' http://www.nytimes.com/books/99/02/21/specials/podhoretz-vietnam.html, Date accessed 19/12/2008.

Ferguson, Niall. (2005) Colossus: The Rise and Fall of the American Empire. New York: Penguin Books.

Fischer, Fritz. (1967) Germany's Aims in the First World War. New York: W.W. Norton.

Flibbert, Andrew. (2006) 'The Road to Baghdad: Ideas and Intellectuals in Explanations of the Iraq War,' Security Studies, vol. 15, no. 2, pp. 310-352.

Freeden, Michael. (1998) Ideologies and Political Theory: A Conceptual Approach. Oxford: Clarendon Press.

Friedman, Murray. (2005) The Neoconservative Revolution: Jewish Intellectuals and the Shaping of Public Policy. Cambridge and New York: Cambridge University Press.

Fromkin, David. (2005) Europe's Last Summer: Who Started the Great War in 1914. New York: Vintage Books.

Frum, David and Perle, Richard. (2004) An End to Evil: How to Win the War on Terror. New York: Ballantine Books.

Fukuyama, Francis. (1989) 'The End of History,' The National Interest, vol. 16 (Summer), pp. 3-18.

Fukuyama, Francis. (1992) The End of History and the Last Man. London and New York: Penguin. 
Fukuyama, Francis. (2005) 'The Neoconservative Moment.' In G. Rosen (ed.) The Right War? The Conservative Debate on Iraq. Cambridge and New York: Cambridge University Press.

Fukuyama, Francis. (2006) America at the Crossroads: Democracy, Power, and the Neoconservative Legacy. New Haven and London: Yale University Press.

Fulbright, James W. (1966) The Arrogance of Power. New York: Random House.

Gaddis, John L. (1992) The US and the End of the Cold War. Oxford and New York: Oxford University Press.

Gaddis, John L. (2004) Surprise, Security, and the American Experience.

Cambridge, Massachusetts, and London: Harvard University Press.

Gaddis, John L. (2005) Strategies of Containment: A Critical Appraisal of American National Security Policy During the Cold War. Oxford and New York: Oxford University Press. Originally published in 1982.

Galbraith, Peter. (2006) The End of Iraq: How American Incompetence Created a War without End. New York: Simon and Schuster.

Garthoff, Raymond L. (1994) Détente and Confrontation: American-Soviet Relations from Nixon to Reagan. Washington D.C.: The Brookings Institution.

Gerson, Mark. (1995) 'Norman's Conquest: A Commentary on the Podhoretz Legacy,' http://www.hoover.org/publications/policyreview/3564402.html, Date accessed 19/12/2008.

Gerson, Mark. (1996) The Neoconservative Vision: From the Cold War to the Culture Wars. Maryland: Madison.

Gilpin, Robert. (2008) War and Change in World Politics. Cambridge and New York: Cambridge University Press. Originally published in 1981.

Glazer, Nathan. (1971) 'Vietnam: The Case for Immediate Withdrawal,' Commentary, May, pp. 33-37.

Glazer, Nathan. (2005) 'Neoconservative from the start,' The Public Interest, no. 159 (Spring), pp. 12-17.

Gleason, Abbot. (1995) Totalitarianism: The Inner History of the Cold War. Oxford and New York: Oxford University Press.

Glendon, Mary A. (2002) A World Made New: Eleanor Roosevelt and the Universal Declaration of Human Rights. New York: Random House Trade Paperbacks. 
Goldhagen, Daniel. (1997) Hitler's Willing Executioners: Ordinary Germans and the Holocaust. New York: Vintage Books.

Goldstein, Judith and Keohane, Robert. (eds.) (1993) Ideas and Foreign Policy: Beliefs, Institutions, and Political Change. Ithaca and London: Cornell University Press.

Gorbachev, Mikhail. (1996) Memoirs. New York: Doubleday.

Gordon, Michael and Trainor, Bernard. (2006) Cobra II: The Inside Story of the Invasion and Occupation of Iraq. New York: Pantheon Books.

Graubard, Stephen. (1973) Kissinger: Portrait of a Mind. New York: Norton. Greene, John. (1995) The Presidency of Gerald R. Ford. Kansas. University of Kansas Press.

Hafez, Mohammed. (2007) Suicide Bombers in Iraq: The Strategy and Ideology of Martyrdom. Washington D.C.: United States Institute of Peace Press.

Halberstam, David. (1992) The Best and the Brightest. New York: Ballantine Books. Originally published in 1972.

Halberstam, David. (2002) War in a Time of Peace: Bush, Clinton, and the Generals, New York: Touchstone.

Halper, Stefan and Clarke, Jonathan. (2004) America Alone: The Neoconservatives and the Global Order. Cambridge and New York: Cambridge University Press.

Hartz, Louis. (1955) The Liberal Tradition in America. New York: Harcourt Brace and Company.

Haslam, Jonathan. (2002) No Virtue Like Necessity. Realist Thought in International Relations since Machiavelli. New Haven and London: Yale University Press.

Heilbrunn, Jacob (2008) They Knew They Were Right: The Rise of the Neocons. New York: Doubleday.

Heilbrunn, Jacob (2009) 'Where Have All the Neocons Gone,' The American Conservative, January 12.

Herrmann, Richard. (2004) 'Regional Conflicts as Turning Points: The Soviet and American Withdrawal from Afghanistan, Angola and Nicaragua.' In R. Herrmann and R. Lebow (eds.) Ending the Cold War: Interpretations, Causation, and the Study of International Relations. New York: Palgrave Macmillan. 
Hersh, Seymour. (2003) Chain of Command: The Road from 9/11 to Abu Ghraib. New York: Harper Collins.

Hiltermann, Joost. (2007) A Poisonous Affair: America, Iraq, and the gassing of Halabja. Cambridge and New York: Cambridge University Press.

Hirst, Aggie. (2009) Intellectuals and US Foreign Policy. In I. Parmar and L. Miller and M. Ledwidge (eds.) New Directions in US Foreign Policy (forthcoming). London: Routledge.

Hitchens, Christopher. (2003) A Long Short War: The Postponed Liberation of Iraq. New York: Penguin Group.

Hitchens, Christopher. (2004) 'An Interview with Christopher Hitchens: Adieu to the Left,' http://www.frontpagemag.com/Articles/ReadArticle.asp?ID=15346, Date accessed 10/11/2004.

Hoffman, Stanley. (1981) Duties Beyond Borders: On the Limits and Possibilities of Ethical International Politics. New York. Syracuse University Press.

Hofstadter, Richard. (1948) The American Political Tradition. New York: Alfred Knopf.

Holmes, Stephen. (2005) 'How Irrational Are Our Enemies.' In D. Gambetta (ed.) Making Sense of Suicide Missions. Oxford and New York: Oxford University Press.

Horner, Charles. (1987) 'Human Rights and the Jackson Amendment.' In D. Fosdick (ed.) Staying the Course: Henry M. Jackson and National Security. Seattle and London: University of Washington Press.

Hunt, Michael. (1987) Ideology and U.S. Foreign Policy. New Haven and London: Yale University Press.

Huntington, Samuel. (1999) 'The Lonely Superpower,' Foreign Affairs, vol. 78, issue. 2, pp. 35-49.

Huntington, Samuel. (2004) Who Are We? America's Great Debate. New York: Simon and Schuster.

Hurst, Steven. (2005) 'Myths of Neoconservatism: George W. Bush's 'NeoConservative' Foreign Policy Revisited,' International Politics, vol. 42, pp. 75-96.

Ignatieff, Michael. (ed.) (2005) American Exceptionalism and Human Rights. New Jersey: Princeton University Press. 
Ikenberry, John. (2001) After Victory: Institutions, Strategic Restraint, and the Rebuilding of Order after Major Wars. Princeton and Oxford: Princeton University Press.

Ikenberry, John. (ed.) (2002) America Unrivaled: The Future of the Balance of Power. Ithaca and London: Cornell University Press.

Ikenberry, John. (2004) 'The End of the Neoconservative Moment,' Survival, vol. 46, no. 1, Spring 2004, pp. 7-22.

Ikenberry, John. (2006) Liberal Order and Imperial Ambition: Essays on American Power and International Order. Cambridge and Malden: Polity. Isaacson, Walter. (2005) Kissinger: A Biography. New York: Simon and Schuster.

Jackson, Henry. (1959/1990) 'Forging a National Strategy.' In D. Fosdick (ed.) Henry M. Jackson and World Affairs: Selected Speeches, 1953-1983. Seattle and London: University of Washington Press.

Jackson, Henry. (1972/1990) 'The Senate and the Interim SALT I Agreement.' In D. Fosdick (ed.) Henry M. Jackson and World Affairs: Selected Speeches, 19531983. Seattle and London: University of Washington Press.

Jackson, Henry. (1973/1990) 'Détente and Human Rights.' In D. Fosdick (ed.) Henry M. Jackson and World Affairs: Selected Speeches, 1953-1983. Seattle and London: University of Washington Press.

Jackson, Henry. (1977/1990) 'Internationally Recognized Human Rights.' In D. Fosdick (ed.) Henry M. Jackson and World Affairs: Selected Speeches, 1953-1983. Seattle and London: University of Washington Press.

Jaffa, Harry. (1959) Crisis of the House Divided: An Interpretation of the Issues in the Lincoln-Douglas Debates. Garden City, New York: Doubleday.

Jaffa, Harry. (2004) A New Birth of Freedom: Abraham Lincoln and the Coming of the Civil War. Lanham, Maryland: Rowman and Littlefield Publishers.

Jervis, Robert. (2003) 'Understanding the Bush Doctrine,' Political Science Quarterly, vol. 118, no. 3 (Fall), pp. 365-388.

Johnson, Chalmers. (2004) The Sorrows of Empire: Militarism, Secrecy, and the End of the Republic. New York: Metropolitan Books.

Juergensmeyer, Mark. (2001) Terror in the Mind of God: The Global Rise of Religious Violence. Berkley and London: University of California Press. 
Kagan, Frederick. (2006) 'We Can Put More Forces in Iraq,' The Weekly Standard, vol. 12, issue. 12, December 4.

Kagan, Frederick, (2007) 'Al Qaeda in Iraq: How to understand it. How to defeat it,' The Weekly Standard, vol. 12, issue 48, September 10.

Kagan, Frederick and Kagan, Kimberly. (2007) 'The New Strategy in Iraq:

General Petraeus learns from past U.S. mistakes,' vol. 12, issue. 40, July 9.

Kagan, Frederick and Kristol, William. (2007) 'All We Are Saying... Is Give Petraeus a Chance,'’ Weekly Standard, vol. 12, issue. 19, January 29.

Kagan, Robert. (1994) 'The Case for Global Activism,' Commentary, vol. 98, issue. 3 (September), pp. 40-44.

Kagan, Robert. (1995a) 'A Retreat from Power,' Commentary, vol. 100, issue. 1 (July), pp. 19-25.

Kagan, Robert. (1995b) 'America, Bosnia, Europe: A Compelling Interest,' http://www.carnegieendowment.org/publications/index.cfm?fa=view\&id=268\&prog= zgp\&proj=zusr, Date accessed 03/06/2007.

Kagan, Robert. (1996a) 'American Power - A Guide for the Perplexed,' Commentary, vol. 101, issue. 4 (April), pp. 21-31.

Kagan, Robert. (1996b) A Twilight Struggle: American Power and Nicaragua1977-1990. New York: Free Press.

Kagan, Robert. (1997) 'Democracies and Double Standards,' Commentary, vol. 104, issue. 2 (August), pp. 19-26.

Kagan, Robert. (1998a) 'Ways to Oust Saddam,' http://www.carnegieendowment.org/publications/index.cfm?fa=view\&id=259\&prog= zgp\&proj=zusr, Date accessed 03/06/07.

Kagan, Robert. (1998b). 'Benevolent Empire,' http://www.carnegieendowment.org/publications/index.cfm?fa=view\&id=275\&prog= zgp\&proj=zusr, Date accessed 03/06/07.

Kagan, Robert. (1999a) 'Clinton's Sorry Excuse for a China Policy,' http://www.carnegieendowment.org/publications/index.cfm?fa=view\&id=253\&prog= zgp\&proj=zusr, Date accessed 14/06/2007.

Kagan, Robert. (1999b) 'China's No. 1 Enemy,' http://www.carnegieendowment.org/publications/index.cfm?fa=view\&id=270\&prog= zgp\&proj=zusr, Date accessed 14/06/2007. 
Kagan, Robert. (1999c) 'Pressuring Taiwan, Appeasing Beijing,' http://www.carnegieendowment.org/publications/index.cfm?fa=view\&id=242\&prog= zch,zgp\&proj=zusr, Date accessed 14/06/2007.

Kagan, Robert. (2000) 'How China Will Take Taiwan,'

http://www.carnegieendowment.org/publications/index.cfm?fa=view\&id=232\&prog= zgp\&proj=zusr, Date accessed 05/08/2007.

Kagan, Robert. (2003) Of Paradise and Power: America and Europe in the New World Order. New York: Alfred Knopf.

Kagan, Robert. (2006a) 'I am not a Straussian. At least, I don't think I am,' Weekly Standard, vol. 11, issue. 20, February 6.

Kagan, Robert. (2006b) Dangerous Nation: America's Place in the World from Its Earliest Days to the Dawn of the Twentieth Century. New York: Alfred Knopf.

Kagan, Robert. (2006c) 'Send More Troops,' http://www.carnegieendowment.org/publications/index.cfm?fa=view\&id=18884\&pro g=zgp\&proj=zusr, Date accessed 17/01/2009.

Kagan, Robert. (2006d) 'It's the regime stupid,' http://www.carnegieendowment.org/publications/index.cfm?fa=view\&id=17960\&pro g=zgp\&proj=zusr, Date accessed 17/01/2009.

Kagan, Robert. (2007a) 'The Blame the Iraqis Gambit,' http://www.carnegieendowment.org/publications/index.cfm?fa=view\&id=19200\&pro g=zgp\&proj=zusr, Date accessed 14/06/2007.

Kagan, Robert. (2007b) 'Obama the Interventionist,' http://www.carnegieendowment.org/publications/index.cfm?fa=view\&id=191138\&pr og=zgp\&proj=zusr, Date accessed 17/01/2009.

Kagan, Robert. (2008) The Return of History and the End of Dreams. London: Atlantic Books.

Kagan, Robert. (2009) 'No Time To Cut Defense,' http://www.carnegieendowment.org/experts/index.cfm?fa=expert_view\&expert_id=1 6\&more=1\#articles, Date accessed 15/05/2009.

Kagan, Robert and Kristol, William. (1999) 'Free Taiwan.' http://www.carnegieendowment.org/publications/index.cfm?fa=view\&id=243\&prog= zgp\&proj=zusr, Date accessed 14/06/2007.

Kagan, Robert and Kristol, William. (2002) 'What to do about Iraq,' The Weekly Standard, vol. 7, issue. 18, January 21. 
Kagan, Robert and Kristol, William. (2004a) 'The Right War for the Right Reasons,' The Weekly Standard, vol. 9, issue. 23, February 23.

Kagan, Robert and Kristol, William. (2004b) 'Too Few Troops,' The Weekly Standard, vol. 9, issue. 31, April 26.

Kahl, Colin. (2007) 'In the Crossfire or the Crosshairs? Norms, Civilian Casualties, and U.S. Conduct in Iraq,' International Security, vol. 32, no. 1, pp. 7-46.

Kaiser, Robert. (2000) '2025 Vision: A China Bent on Asian Dominance,' Washington Post, March 17.

Kane, John. (2008) Between Virtue and Power: The Persistent Moral Dilemma of U.S. Foreign Policy. Yale: Yale University Press.

Kaplan, Lawrence and Kristol, William (2003) The War Over Iraq: Saddam's Tyranny and America's Mission. San Francisco: Encounter Books.

Kapstein, Ethan and Mastanduno, Michael. (eds.) (1999) Unipolar Politics: Realism and State Strategies After the Cold War. New York: Columbia University Press.

Katzenstein, Suzanne and Snyder, Jack. (2009) 'Expediency of the Angels,' The National Interest, issue. 100 (March/April), pp. 58-65.

Kaufman, Robert G. (2000) Henry M. Jackson: A Life in Politics. Seattle and London: University of Washington Press.

Kelly, Michael. (2008) Ghosts of Halabja: Saddam Hussein and the Kurdish Genocide. West Port, Connecticut: Praeger.

Kengor, Paul. (2007) The Crusader: Ronald Reagan and the Fall of Communism. New York and London: Harper Perennial.

Kennan, George. (1983) George F. Kennan Memoirs 1925-1950. New York:

Pantheon Books. Originally published in 1967.

Kennan, George. (1985/86) 'Morality and Foreign Policy,' Foreign Affairs, vol. 64 , issue 2.

Kennedy, Paul. (2007) The Parliament of Man: The Past, Present, and Future of the United Nations. New York: Vintage Books.

Keohane, Robert. (1984) After Hegemony: Cooperation and Discord in the World Political Economy. Princeton: Princeton University Press.

Kershaw, Ian. (2007) Fateful Choices: Ten Decisions That Changed The World. New York: The Penguin Press. 
Khalilzad, Zalmay (1995) 'Losing the moment? The United States and the world after the Cold War,' The Washington Quarterly, vol. 18, no. 2 (Spring), pp 87-107.

Khalilzad, Zalmay. and Wolfowitz, Paul. (1997) 'Overthrow Him,' Weekly Standard, vol. 3, issue. 12, December 1.

Khosrokhavar, Farhad. (2005) Suicide Bombers: Allah's New Martyrs. London and Ann Arbor: Pluto Press.

Kimball, Jeffrey. (2006) 'The Nixon Doctrine: A Saga of Misunderstanding,' Presidential Studies Quarterly, vol. 36, no. 1 (March), pp. 59-74.

Kimball, Warren. (2003) Forged in War: Roosevelt, Churchill, and the Second World War. Chicago: Ivan R. Dee. Originally published in 1997.

Kinzer, Stephen. (2006) Overthrow: America's Century of Regime Change From Hawaii to Iraq. New York: Times Books.

Kirkpatrick, Jeane. (1981) 'Human Rights and American Foreign Policy: A Symposium,' Commentary, November, pp. 42-45.

Kirkpatrick, Jeane. (1979/1982) 'Dictatorships and Double Standards.' In J. Kirkpatrick (ed.) Dictatorships and Double Standards: Rationalism and Reason in Politics. New York: Simon and Schuster.

Kirkpatrick, Jeane. (1983/1988) 'The Plight of Soviet Jews.' In J. Kirkpatrick (ed.) Legitimacy and Force: Volume One Political and Moral Dimensions. New Brunswick and Oxford: Transaction Books.

Kirkpatrick, Jeane. (1985/1990) 'Who Knows What Gorbachev Wants?' In J. Kirkpatrick (ed.) The Withering Away of the Totalitarian State. Washington D.C.: The AEI Press.

Kirkpatrick, Jeane. (1985/1988) 'The Reagan Doctrine I.’ In J. Kirkpatrick (ed.) Legitimacy and Force: Volume One Political and Moral Dimensions. New Brunswick and Oxford: Transaction Books.

Kirkpatrick, Jeane. (1986/1988) 'The Reagan Doctrine III.’ In J. Kirkpatrick (ed.) Legitimacy and Force: Volume One Political and Moral Dimensions. New Brunswick and Oxford: Transaction Books.

Kirkpatrick, Jeane. (1987/1990) 'The New Styles of the New Bolsheviks.' In J. Kirkpatrick (ed.) The Withering Away of the Totalitarian State. Washington D.C.: The AEI Press.

Kirkpatrick, Jeane. (1990a) 'Beyond the Cold War,' Foreign Affairs, vol. 69, issue. 1, pp 1-16. 
Kirkpatrick, Jeane. (1990b) The Withering Away of the Totalitarian State. Washington D.C.: The AEI Press.

Kirkpatrick, Jeane. (1990b) The Withering Away of the Totalitarian State. Washington D.C.: The AEI Press.

Kirkpatrick, Jeane. (2004) 'Neoconservatism as a Response to the Counterculture.' In I. Stelzer (ed.) The Neocon Reader. New York: Grove Press.

Kirkpatrick, Jeane. (2007) Making War to Keep Peace. New York: Harper Collins.

Kirkpatrick, Jeane and Gerson, Allan. (1989) 'The Reagan Doctrine, Human Rights, and International Law.' In L. Henkin, S. Hoffman, J. Kirkpatrick, A. Gerson, W. Rogers, and D. Scheffer (eds.) Right v. Might: International Law and the Use of Force. New York: Council on Foreign Relations.

Kissinger, Henry. (1964) A World Restored. New York: Grosset and Dunlap.

Kissinger, Henry (1979) White House Years. Boston: Little, Brown.

Kissinger, Henry. (1994) Diplomacy. New York: Simon \& Schuster.

Kissinger, Henry. (2000) Years of Renewal. New York: Touchstone.

Kissinger, Henry. (2002) Does America Need A Foreign Policy? New York: Touchstone.

Krauthammer, Charles. (1985) 'The Reagan Doctrine,' Time, http://www.time.com/time/magazine/article/0,9171,964873,00.html, Date accessed 07/08/2008.

Krauthammer, Charles. (1989/1990) 'Universal Dominion: Toward A Unipolar World,' The National Interest, issue. 18 (Winter), pp. 46-49.

Krauthammer, Charles. (1990/1991) 'The Unipolar Moment,' Foreign Affairs, vol. 70, issue. 1 (Winter), pp. 23-33.

Krauthammer, Charles. (1993a) 'The doves are right about Bosnia,' Time, vol. 141 , issue. 6 , p. 86.

Krauthammer, Charles. (1993b) 'How the doves became hawks,' Time, vol. 141, issue. 20 , p. 74.

Krauthammer, Charles. (1994a) 'To the rescue of ingrates,' Time, vol. 144, issue. 15, p. 94.

Krauthammer, Charles. (1994b) 'Bob Dole’s Bosnia folly,' Time, vol. 144, issue. 24, p. 102. 
Krauthammer, Charles. (1999a) 'The Short, Unhappy Life of Humanitarian War,' The National Interest, issue. 57 (Fall), pp. 5-8.

Krauthammer, Charles. (1999b) 'The Clinton Doctrine,' Time, vol. 153, issue. 13, p. 88.

Krauthammer, Charles. (1999c) 'The limits of humanitarianism,' Time, vol. 154, issue 13, p. 118.

Krauthammer, Charles. (2001a) 'Its time to change regimes,' http://townhall.com/columnists/CharlesKrauthammer/2001/09/28/its_time_to_change _regimes, Date accessed 15/12/2005.

Krauthammer, Charles. (2001b) 'The great coalition debate rages on,' http://townhall.com/columnists/CharlesKrauthammer/2001/10/19/the_great_coalition _debate_rages_on, Date accessed 15/12/2005.

Krauthammer, Charles. (2001c) 'No to nation building,' http://townhall.com/columnists/CharlesKrauthammer/2001/12/18/no_to_nation_buildi ng, Date accessed 25/01/2006.

Krauthammer, Charles. (2001d) 'This war is different and must be won,' http://townhall.com/columnists/CharlesKrauthammer/2001/10/30/this_war_is_differe nt_and_must_be_won, Date accessed 03/11/2006.

Krauthammer, Charles (2002/2003) 'The Unipolar Moment Revisited,' The National Interest, issue. 70 (Winter), pp. 5-17.

Krauthammer, Charles. (2004) 'Democratic Realism: An American Foreign Policy for a Unipolar World,' http://www.aei.org/include/pub_print.asp?pubID=19912, Date accessed 29/03/2006.

Krauthammer, Charles. (2005) 'The Neocon Convergence,' Commentary, vol. 20, issue. 1 (July-August), pp. 21-27.

Krauthammer, Charles. (2006) 'Civil war is nothing new,' http://townhall.com/columnists/CharlesKrauthammer/2006/03/24/civil_war_is_nothin g_new, Date accessed 26/12/2008.

Krauthammer, Charles. (2007a) 'The Fight in Najaf,' http://townhall.com/columnists/CharlesKrauthammer/2007/02/02/the_fight_in_najaf, Date accessed 26/12/2008.

Krauthammer, Charles. (2007b) 'Botched,' http://townhall.com/columnists/CharlesKrauthammer/2007/01/05/botched, Date accessed 26/12/2008. 
Krauthammer, Charles. (2007c) 'Maliki doesn't deserve a 'surge,', http://townhall.com/columnists/CharlesKrauthammer/2007/01/19/maliki_doesn't_des erve_a_surge, Date accessed 26/12/2008.

Krauthammer, Charles. (2007d) 'Forcing U.S. to quit in Iraq,' http://townhall.com/columnists/CharlesKrauthammer/2007/04/13/forcing_us_to_quit_ in_iraq, Date accessed 26/12/2008.

Krauthammer, Charles. (2007e) 'Washington vs. The Surge,' http://townhall.com/columnists/CharlesKrauthammer/2007/07/13/washington_vs_the _surge, Date accessed 26/12/2008.

Krauthammer, Charles. (2007f) 'Petraeus' Bargain,' http://townhall.com/columnists/CharlesKrauthammer/2007/07/20/petraeus_bargain, Date accessed 26/12/2008.

Krauthammer, Charles. (2007g) 'The debate on Iraq takes a turn,' http://townhall.com/columnists/CharlesKrauthammer/2007/08/24/the_debate_on_iraq _takes_a_turn, Date accessed 26/12/2008.

Krauthammer, Charles. (2008) 'Who Does He Think He Is?' http://www.townhall.com/columnists/CharlesKrauthammer/2008/07/18/who_does_he _think_he_is, Date accessed 25/07/2008.

Krauthammer, Charles. (2009) 'It's Your Country Too, Mr. President,' http://townhall.com/columnists/CharlesKrauthammer/2009/04/10/its_your_country_to o,_mr_president, Date accessed 21/04/2009.

Kristol, Irving. (1967/1999) 'American Intellectuals and Foreign Policy.' In I. Kristol (ed.) Neoconservatism: The Autobiography of an Idea. Chicago. Ivan Dee.

Kristol, Irving. (1970/1999) 'American Historians and the Democratic Idea.' In I. Kristol (ed.) Neoconservatism: The Autobiography of an Idea. Chicago. Ivan Dee.

Kristol, Irving. (1979a/1983) 'Confessions of a True, Self-Confessed - Perhaps the Only - Neoconservative.' In I. Kristol (ed.) Reflections of a Neoconservative: Looking Back, Looking Ahead. New York: Basic Books.

Kristol, Irving. (1979b/1983). 'Does NATO Exist?' In I. Kristol (ed.) Reflections of a Neoconservative: Looking Back, Looking Ahead. New York: Basic Books.

Kristol, Irving. (1983) Reflections of a Neoconservative: Looking Back, Looking Ahead. New York: Basic Books. 
Kristol, Irving. (1992/1999) 'The Cultural Revolution and the Capitalist Future.' In I. Kristol (ed.) Neoconservatism: The Autobiography of an Idea. Chicago. Ivan Dee.

Kristol, Irving. (1993/1999) 'My Cold War.' In I. Kristol (ed.) Neoconservatism: The Autobiography of an Idea. Chicago. Ivan Dee.

Kristol, Irving. (1995/1999) 'An Autobiographical Memoir.' In I. Kristol (ed.) Neoconservatism: The Autobiography of an Idea. Chicago. Ivan Dee.

Kristol, Irving. (2000) 'A Post-Wilsonian Foreign Policy,' http://www.aei.org/article/6811, Date accessed 04/09/2006.

Kristol, Irving. (2003) 'The Neoconservative Persuasion,' The Weekly Standard, vol. 8, issue. 47, August 25.

Kristol, Irving. (2005) 'Empire Builders: In their own words,' Christian Science Monitor, http://www.csmonitor.com/specials/neocon/neoconQuotes.html, Date accessed 18/04/2007.

Kristol, William (2004a). The Theodore H. White Lecture with William Kristol. Boston: Harvard University, John F. Kennedy School of Government.

Kristol, William (2004b) 'The Defense Secretary We Have,' The Washington Post, December 14, p. A33.

Kristol, William. (2006) 'It's Our War: Bush should go to Jerusalem - and the U.S. should confront Iran,' The Weekly Standard, vol. 11, issue. 42, July 24.

Kristol, William and Kagan, Robert. (1996) "Toward a Neo-Reaganite Foreign Policy,' Foreign Affairs, vol. 75, issue. 4, pp. 18-33.

Kristol, William and Kagan, Robert. (1999) 'Victory,' http://www.carnegieendowment.org/publications/index.cfm?fa=view\&id=245\&prog= zgp\&proj=zusr, Date accessed 20/12/2008.

Kristol, William and Kagan, Robert. (2000) 'Introduction: National Interest and Global Responsibility.' In R. Kagan and W. Kristol (eds.) Present Dangers: Crisis and Opportunity in American Foreign and Defense Policy. San Francisco: Encounter Books.

Kristol, William and Serchuk, Vance. (2004) 'End the Genocide Now,' http://www.washingtonpost.com/ac2/wp-dyn/A40121-2004sep21 ?language=printer, Date accessed 12/03/2006. 
Kupchan, Charles. (1998) 'After Pax Americana: benign power, regional integration, and the sources of a stable multipolarity,' International Security, vol. 23, no. 2 (Fall), pp. 40-79.

Kupchan, Charles. (2003) The End of the American Era: U.S. Foreign Policy and the Geopolitics of the Twenty-First Century. New York: Vintage Books.

Laqueur, Walter. (1975) 'The West in Retreat,' Commentary, vol. 60, issue. 5 (August), pp. 44-52.

Laqueur, Walter. (1983) 'What We Know About the Soviet Union,' Commentary, vol. 72, issue. 2 (February), pp. 13-21.

Laqueur, Walter. (1985) 'Is There Now, or Has There Ever Been, Such a Thing as Totalitarianism,' Commentary, vol. 80, issue. 4 (October), pp. 29-35.

Layne, Christopher. (1993) 'The Unipolar Illusion: Why New Great Powers Will Rise,' International Security, vol. 17, no. 4 (Spring), pp. 5-51.

Layne, Christopher. (1994) 'Kant or Cant: The Myth of the Democratic Peace,' International Security, vol. 19, no. 2 (Fall), pp. 5-49.

Layne, Christopher. (2006a) 'The Unipolar Illusion Revisited,' International Security, vol. 31, no. 2 (Fall), pp 7-41.

Layne, Christopher. (2006b) The Peace of Illusions: American Grand Strategy from 1940 to the Present. Ithaca and London: Cornell University Press.

Leffler, Melvyn. (1992) A Preponderance of Power: National Security, the Truman Administration, and the Cold War. Stanford: Stanford University Press.

Leffler, Melvyn. (2004) 'Bush's Foreign Policy,' Foreign Policy, issue. 144 (September/October), pp. 22-28.

Leffler, Melvyn. (2007) For the Soul of Mankind: The United States, the Soviet Union, and the Cold War. New York: Hill and Wang.

Legro, Jeffrey. (2005) Rethinking the World: Great Power Strategies and International Order. Ithaca and London: Cornell University Press.

Lenzner, Steven and Kristol, William. (2003) 'What was Leo Strauss up to?' The Public Interest, no. 153 (Fall), pp. 19-39.

Leo Grande, William M. (1998) Our Own Backyard: The United States in Central America, 1977-1992. Chapel Hill and London: The University of North Carolina Press. 
'Letter to Congress on Increasing U.S. Ground Forces.' (2005) Project for a New American Century, http://www.newamericancentury.org/defense-20050128.htm, Date accessed 05/02/2009.

'Letter to President Clinton on Iraq.' (1998) Project for a New American Century, http://www.newamericancentury.org/iraqclintonletter.htm, Date accessed 18/04/2007.

'Letter to President Clinton on Milosevic.' (1998) Project for a New American Century, http://www.newamericancentury.org/kosovomilosevicsep98.htm, Date accessed 25/04/07.

'Letter to President Bush on the war on terrorism.' (2001) Project for a New American Century, http://www.newamericancentury.org/Bushletter.htm, Date accessed 13/03/2006.

Lettow, Paul. (2006) Ronald Reagan and His Quest to Abolish Nuclear Weapons. New York: Random House.

Levesque, Jacques (2004a) 'The Messianic Character of Gorbachev's 'New Thinking': Why and What For?' In O. Njolstad (ed.) The Last Decade of the Cold War. London and New York: Frank Cass Publishers.

Levesque, Jacques (2004b) 'The Emancipation of Eastern Europe.' In R.

Herrmann and R. Lebow (eds.) Ending the Cold War: Interpretations, Causation, and the Study of International Relations. New York: Palgrave Macmillan.

Levy, Jack. (2004) 'What Do Great Powers Balance Against and When.' In T.V. Paul, J. Wirtz, and M. Fortmann (eds.) Balance of Power: Theory and Practice in the $21^{\text {st }}$ Century. Stanford: Stanford University Press.

Lewis, Bernard. (1987) 'Senator Jackson and the U.S. Relationship with Israel.' In D. Fosdick (ed.) Staying the Course: Henry M. Jackson and National Security. Seattle and London: University of Washington Press.

Lewis, Bernard. (2002) What Went Wrong? Western Impact and Middle Eastern Response. London: Phoenix.

Lewis, Bernard. (2004) The Crisis of Islam: Holy War and Unholy Terror. London: Phoenix.

Lewis, Bernard. (2005) 'The Roots of Muslim Rage.' In B. Lewis (ed.) From Babel to Dragomans: Interpreting the Middle East. London: Phoenix.

Lieber, Keir. (2007) 'The New History of World War 1 and What it Means for International Relations Theory,' International Security, vol. 32, no. 2 (Fall), pp. 155191. 
Lieber, Keir and Alexander, Gerard. (2005) 'Waiting for Balancing: Why the World Is Not Pushing Back,' International Security, vol. 30, no. 1 (Summer), pp. 109139.

Lieber, Robert. (2005) The American Era: Power and Strategy for the $21^{\text {st }}$ Century. Cambridge and New York: Cambridge University Press.

Lieber, Robert. (2008) 'Falling Upwards: Declinism, The Box Set,' World Affairs, vol. 171, issue. 1, pp. 48-56.

Lieber, Robert. (2009) 'Persistent Primacy and the future of the American era,' International Politics, vol. 46, issue. 2-3, pp. 119-139.

Lieven, Anatol. (2004) America Right or Wrong: An Anatomy of American Nationalism. Oxford and New York: Oxford University Press.

Lieven, Anatol and Hulsman, John. (2006) Ethical Realism: A Vision for America's Role in the World. New York: Pantheon Books.

Lilla, Mark. (2004a) 'Leo Strauss: The European,' The New York Review of Books, vol. 51, no. 16, pp 58-60.

Lilla, Mark. (2004b) 'The Closing of the Straussian Mind,' New York Review of Books, vol. 51, no. 17, pp 55-59.

Lincoln, Abraham. (1858/2004) The Lincoln-Douglas Debates. Mineola, New York: Dover Publications, Inc.

Lind, Michael. (2006) The American Way of Strategy: U.S. Foreign Policy and the American Way of Life. Oxford and New York: Oxford University Press.

Lipset, Seymour M. (1996) American Exceptionalism: A Double Edged Sword. New York: Norton.

Litwak, Robert (1984) Détente and the Nixon Doctrine: American Foreign Policy and the Pursuit of Stability. Cambridge and New York: Cambridge University Press.

Lord, Carnes. (2003) The Modern Prince: What Leaders Need to Know Now.

New Haven and London: Yale University Press.

Lucas, Edward. (2008) The New Cold War: Putin's Russia and the Threat to the West. New York: Palgrave Macmillan.

Luttwak, Edward and Laqueur, Walter. (1974) 'Kissinger and the Yom Kippur War,' Commentary, vol. 58, no. 3 (September), pp. 33-40.

Lynch, Timothy and Singh, Robert (2008) After Bush: The Case for Continuity in American Foreign Policy. Cambridge and New York: Cambridge University Press. 
Lyon, Alynna and Dolan, Chris. (2007) 'American Humanitarian Intervention: Toward a Theory of Coevolution,' Foreign Policy Analysis, vol. 3, issue. 1 (January), pp. 46-78.

Mackby, Jenifer and Slocombe, Walter (2004) 'Germany: The Model Case, A Historical Imperative.' In K. Campbell, R. Einhorn, and M. Reiss (eds.) The Nuclear Tipping Point: Why States Reconsider Their Nuclear Choices. Washington D.C.: Brookings Institution Press.

Macmillan, Margaret. (2003) Paris 1919. New York: Random House.

Mandelbaum, Michael. (2005) The Case for Goliath: How America Acts as the World's Government in the $21^{\text {st }}$ Century. New York: Public Affairs.

Mann, James. (2004) Rise of the Vulcans: The History of Bush's War Cabinet. New York: Penguin Books.

Marshall, Andrew. (1991) 'Strategy as a Profession for Future Generations.' In A. Marshall, J. J. Martin, and H. Rowen (eds.) On Not Confusing Ourselves: Essays on National Security in Honor of Albert and Roberta Wohlstetter. Boulder, Colorado: Westview Press.

Mason, John. (2004) 'Leo Strauss and the Noble Lie: The Neo-Cons at War,' Logos, Spring.

McCain, John. (2007) 'An Enduring Peace Built on Freedom,' Foreign Affairs, vol. 86, issue. 6 (November/December), p. 19.

McDermott, Terry. (2005) Perfect Soldiers: Who They Were, Why They Did It. New York: HarperCollins.

McDougall, Walter. (1997) Promised Land, Crusader States: The American Encounter with the World since 1776. Boston and New York: Houghton Mifflin Company.

McNamara, Robert. (1996) In Retrospect: The Tragedy and Lessons of Vietnam. New York: Vintage Books.

Mead, Walter R. (2002) Special Providence: American Foreign Policy and How It Changed the World. New York and London: Routledge.

Mead, Walter R. (2007) 'Jerusalem Syndrome: Decoding the Israel Lobby,'” Foreign Affairs, vol. 86, issue. 6, pp. 160-168.

Mead, Walter R. (2008) 'The New Israel and the Old: Why Gentile Americans Back the Jewish State,' Foreign Affairs, vol. 87, issue. 4, pp. 28-46. 
Mearsheimer, John. (1990) 'Back to the Future: Instability in Europe after the Cold War,' International Security, vol. 15, no. 1 (Summer), pp. 5-56.

Mearsheimer, John. (2003) The Tragedy of Great Power Politics. New York and London: W.W. Norton and Company.

Mearsheimer, John and Walt, Stephen. (2006) 'The Israel Lobby,' London Review of Books, vol. 28, no. 6, pp. 3-12.

Micklethwait, John and Wooldridge, Adrian. (2005) Right Nation: Why America is Different. New York: Penguin Books.

Miscamble, Wilson. (2007) From Roosevelt to Truman: Potsdam, Hiroshima, and the Cold War. Cambridge and New York: Cambridge University Press.

Morgenthau, Hans. (1951) In Defense of the National Interest: A Critical Examination of American Foreign Policy. New York: Alfred Knopf.

Morgenthau, Hans. (1961) 'Asia: The American Algeria,' Commentary, July.

Morgenthau, Hans. (1962) 'Vietnam-Another Korea?' Commentary, May.

Morgenthau, Hans. (1963) 'On Trying to be Just,' Commentary, May.

Morgenthau, Hans. (1965) Vietnam and the United States. Washington D.C.: Public Affairs Press.

Morgenthau, Hans. (1993) Politics Among Nations: The Struggle for Power and Peace. New York: McGraw-Hill. Brief edition. Originally published in 1948.

Morone, James. (2004) Hellfire Nation: the Politics of Sin in American History. New Haven and London: Yale University Press.

Morris, Benny. (2001) Righteous Victims: A History of the Zionist-Arab Conflict, 1881-2001. New York: Vintage Books.

Moynihan, Daniel P. (1974) 'Was Woodrow Wilson Right?' Commentary, May, pp. 25-31.

Moynihan, Daniel P. (1975/1996) 'Statement by Daniel P. Moynihan, United States Representative to the United Nations, in Plenary, in Response to the United Nations Resolution Equating Zionism with Racism and Racial Discrimination, Nov 10, 1975. In M. Gerson (ed.) The Essential Neoconservative Reader. Massachusetts: Addison-Wesley Publishing Company.

Moynihan, Daniel P. (1975) 'The United States in Opposition,' Commentary, March, pp. 31-44.

Moynihan, Daniel P. (1977) 'The Politics of Human Rights,' Commentary, August, pp. 19-26. 
Moynihan, Daniel P. (1984a/1988) 'U.S. Has Abandoned International Law.' In

D. Moynihan (ed.) Came the Revolution. San Diego: Harcourt Brace Jovanovich. Moynihan, Daniel P. (1984b/1988) 'Commencement Address, New York

University.' In D. Moynihan (ed.) Came the Revolution. San Diego: Harcourt Brace Jovanovich.

Muravchik, Joshua. (1986) The Uncertain Crusade: Jimmy Carter and the Dilemmas of Human Rights Policy. Lanham and London: Hamilton Press.

Muravchik, Joshua. (1991) Exporting Democracy: Fulfilling America's Destiny. Washington, D.C.: The AEI Press.

Muravchik, Joshua. (1992) 'The Strange Debate Over Bosnia,' Commentary, vol. 94, issue. 5, pp. 30-37.

Muravchik, Joshua (2002) 'The UN on the Loose,' Commentary, vol. 114, issue. 1 (July/August), pp. 29-32.

Muravchik, Joshua. (2003) 'Facing Up to North Korea,' Commentary, vol. 115, issue. 3 , pp. 33-38.

Muravchik, Joshua (2004) 'The Case against the UN,' Commentary, vol. 118, issue. 4 (November), pp. 36-42.

Muravchik, Joshua (2005) The Future of the United Nations: Understanding the Past to Chart a Way Forward. Washington, D.C.: The AEI Press.

Muravchik, Joshua. (2006) 'Bomb Iran,' Los Angeles Times, http://www.latimes.com/news/opinion/la-op-muravchik19nov19,0,1681154.story, Date accessed 24/02/2009.

Muravchik, Joshua. (2007) 'The Neoconservative Persuasion and Foreign Policy,'http://www.aei.org/article/100212, Date accessed 08/02/2008.

Muravchik, Joshua. (2008) 'Obama’s Talking Tour,' Commentary, vol. 126, issue. 2 (September), pp. 27-31.

Murray, Douglas. (2006) Neoconservatism: Why We Need It. New York: Encounter Books.

Naji, Kasra. (2008) Ahmadinejad: The Secret History of Iran's Radical Leader. London and New York: I.B. Tauris.

Nance, Malcolm. (2007) The Terrorists of Iraq: Inside the Strategy and Tactics of the Iraq Insurgency. Charleston, South Carolina: BookSurge.

Nash, George. (2006) The Conservative Intellectual Movement in America. Delaware: ISI Books. Third edition. Originally published in 1976. 
Newhouse, John. (2009) 'Diplomacy, Inc.,' Foreign Affairs, volume 88, no. 3, pp. 73-92.

Nicgorski, Walter. (1999) 'Allan Bloom, Strauss, Socrates, and Liberal

Education.' In K. Deutsch and J. Murley (eds.) Leo Strauss, the Straussians, and the American Regime. Maryland: Rowman \& Littlefield.

Nixon, Richard. (1967/1968) 'Asia after Vietnam,' Foreign Affairs, vol. 46, pp. $111-125$

Nixon, Richard. (1972) 'An Interview with the President: The Jury is Out,' Time, vol. 99, no. 1 (January 3), p. 15.

Nixon, Richard. (1978) RN: The Memoirs of Richard Nixon. New York: Grosset and Dunlap.

Obama, Barack. (2007) 'Renewing American Leadership,' Foreign Affairs, vol. 86 , issue. 4 , pp. 2-16.

Obama, Barack. (2007/2008) 'Declaration of Candidacy.' In Change We Can Believe In: Barack Obama's Plan to Renew America's Promise. Melbourne: Text Publishing.

Oberdorfer, Don. (1998) From the Cold War to a New Era: The United States and the Soviet Union, 1983-1991. Baltimore and London: The John Hopkins University Press.

O’Connor, Brendon. (ed.) (2007) Anti-Americanism [4 Volumes]: History, Causes, Themes. Oxford and Connecticut: Greenwood World Publishing.

Oliver, Anne-Marie and Steinberg, Paul. (2006) The Road to Martyr's Square: A Journey into the World of the Suicide Bomber. Oxford and New York: Oxford University Press.

Orr, Robert. (2004) 'The United States as Nation Builder: Facing the Challenge of Post-Conflict Reconstruction.' In R. Orr (ed.) Winning the Peace: An American Strategy for Post-Conflict Reconstruction. Washington, D.C.: The CSIS Press.

Orwell, George. (2005) Nineteen Eighty-Four. London. Penguin Books. Originally published in 1948.

Orwin, Clifford. (1996) 'Distant Compassion: CNN and Borriobolla-Gha,' National Interest, issue. 42 (Spring), pp. 42-49.

Orwin, Clifford. (1997) 'Rousseau and the Discovery of Political Compassion.' In C. Orwin \& N. Tarcov (eds.) The Legacy of Rousseau. Chicago: University of Chicago. 
Owen, John. (1997) Liberal Peace, Liberal War. Ithaca and London: Cornell University Press.

Packer, George. (2005) The Assassins Gate: America in Iraq. New York: Farrar, Straus and Giroux.

Packer, George. (2008) 'The New Liberalism,' The New Yorker, vol. 84, issue. 37, p. 84.

Pangle, Thomas. (1989) The Rebirth of Classical Political Rationalism: An Introduction to the thought of Leo Strauss. Chicago: The University of Chicago Press.

Pangle, Thomas. (1990) The Spirit of Modern Republicanism: The Moral Vision of the American Founders and the Philosophy of Locke. Chicago: The University of Chicago Press.

Pangle, Thomas. (2006) Leo Strauss: An Introduction to His Thought and Intellectual Legacy. Maryland: The John Hopkins University Press.

Pape, Robert. (2005a) Dying to Win: The Strategic Logic of Suicide Terrorism. Melbourne: Scribe.

Pape, Robert. (2005b) 'Soft Balancing against the United States,' International Security, vol. 30, no. 1 (Summer), pp. 7-45.

Paul, T.V. (2005) 'Soft Balancing in the Age of U.S. Primacy,' International Security, vol. 30, no. 1 (Summer), pp. 46-71.

Pemberton, William E. (1998) Exit with Honor: The Life and Presidency of Ronald Reagan. New York and London: M.E. Sharpe.

Perle, Richard. (2005) 'Empire Builders: In their own words,' Christian Science Monitor, http://www.csmonitor.com/specials/neocon/neoconQuotes.html, Date accessed 18/04/2007.

Perle, Richard. (2007). A response to I. Daalder and J. Lindsay, 'Democracies of the World, Unite,' The American Interest, vol. 2, issue. 3, pp. 17-18.

Phillips, David. (2005) Losing Iraq: Inside the Postwar Reconstruction Fiasco. Boulder, Colorado: Westview Press.

Pipes, Richard. (1977) 'Why the Soviet Union Thinks It Could Fight and Win a Nuclear War,' Commentary, July, pp. 21-34.

Pipes, Richard. (1980) 'Soviet Global Strategy,' Commentary, April, pp. 31-39.

Pipes, Richard. (1984) 'How to Cope with the Soviet Threat: A Long Term Strategy for the West,' Commentary, August, pp. 13-30. 
Pipes, Richard. (1995) 'Misinterpreting the Cold War: The Hardliners Had It Right,' Foreign Affairs, vol. 74, no. 1, pp. 154-160.

Podhoretz, Norman. (1971) 'A Note on Vietnamizaton,' Commentary, May.

Podhoretz, Norman. (1976) 'Making the World Safe for Communism,'

Commentary, April, pp. 31-41.

Podhoretz, Norman. (1979) Breaking Ranks: A Political Memoir. New York: Harper and Row.

Podhoretz, Norman. (1980a) 'The Present Danger,' Commentary, March, pp. 2740.

Podhoretz, Norman. (1980b) The Present Danger: Do We Have the Will to Reverse the Decline of American Power? New York: Simon and Schuster.

Podhoretz, Norman. (1981) 'The Future Danger,' Commentary, April, pp. 29-47.

Podhoretz, Norman. (1982a) 'Kissinger Reconsidered,' Commentary, June, pp. $19-28$

Podhoretz, Norman. (1982b) Why We Were In Vietnam. New York: Simon and Schuster.

Podhoretz, Norman. (1983) 'Appeasement By Any Other Name,' Commentary, July, pp. 25-38.

Podhoretz, Norman. (1985) 'The Reagan Road to Détente,' Foreign Affairs, vol. 63 , issue. 3 , pp. 447-464.

Podhoretz, Norman. (1999) Ex-Friends: Falling Out with Allen Ginsberg, Lionel and Diana Trilling, Lillian Hellman, Hannah Arendt, and Norman Mailer. New York: The Free Press.

Podhoretz, Norman. (2000) My Love Affair with America: The Cautionary Tale of a Cheerful Conservative. New York: The Free Press.

Podhoretz, Norman. (2004) 'World War IV: How It Started, What It Means, and Why We Have to Win,' Commentary, vol. 18, issue. 2, pp. 17-54.

Podhoretz, Norman. (2006) 'Is the Bush Doctrine Dead?' Commentary, vol. 122, issue. 2, pp. 17-31.

Podhoretz, Norman. (2007a) World War 1V: the Long Struggle against Islamofacism. New York: Double Day.

Podhoretz, Norman. (2007b) 'The Case for Bombing Iran,' Commentary, vol. 123, issue. 6, pp. 17-23. 
Podhoretz, Norman. (2008) 'Stopping Iran: Why the case for military action still stands,' Commentary, vol. 125, issue. 2, pp. 11-19.

Pollack, Kenneth. (2005) The Persian Puzzle: The Conflict Between Iran and America. New York: Random House.

Power, Samantha. (2003) A Problem from Hell: America and the Age of Genocide. London: Flamingo.

Powers, Richard. (1998) Not Without Honor: The History of American antiCommunism. New Haven and London: Yale University Press.

Rashid, Ahmed. (2008) Descent into Chaos: How the war against Islamic extremism is being lost in Pakistan, Afghanistan and Central Asia. London and New York: Allen Lane.

Rebuilding America's Defenses. (2000) Project for a New American Century, http://www.newamericancentury.org/RebuildingAmerica'sDefenses.pdf, Date accessed 04/11/2007.

Record, Jeffrey. (2003) 'The Bush Doctrine and War with Iraq,' Parameters, Spring, pp. 4-21.

Regional Defense Strategy. (1993) http://www.informationclearinghouse.info/pdf/naarpr_Defense.pdf, Date accessed 19/03/2007.

Reiter, Dan and Stam, Allan. (2002) Democracies At War. Princeton and Oxford: Princeton University Press.

Reynolds, David. (2007) Summits: Six Meetings that Shaped the Twentieth Century. New York: Basic Books.

Rice, Condoleezza. (2000) 'Promoting the National Interest,' Foreign Affairs, vol. 79, issue. 1 (January/February), pp. 45-62.

Ricks, Thomas. (2006) Fiasco: The American Military Adventure in Iraq. New York: The Penguin Press.

Ricks, Thomas. (2009) The Gamble: General Petraeus and the American Military Adventure in Iraq, 2006-2008. New York: The Penguin Press.

Riedel, Bruce. (2008) The Search for al-Qaeda: Its Leadership, Ideology, and Future. Washington D.C.: Brookings Institution Press.

Rieff, David. (2006) At The Point of a Gun: Democratic Dreams and Armed Intervention. New York: Simon and Schuster. 
Robinson, Linda (2008) Tell Me How This Ends: General David Petraeus and the Search for a Way Out Of Iraq. New York: Public Affairs.

Rosato, Sebastian (2003) 'The Flawed Logic of Democratic Peace Theory,' The American Political Science Review, vol. 97, issue. 4 (November), pp. 585-602.

Rose, David. (2007) 'Now They Tell Us: Neo Culpa,' Vanity Fair, http://www.vanityfair.com/politics/features/2006/12/neocons200612, Date accessed 07/04/2009.

Rostow, Eugene. (1974) 'America, Europe, and the Middle East,' Commentary, February, pp. 40-55.

Rostow, Eugene. (1979) 'The Case Against SALT II,' Commentary, February, pp. 23-28.

Roy, Oliver. (2004) Globalised Islam: The Search for a New Ummah. New York: Columbia University Press.

Russet, Bruce. (1996) 'Why Democratic Peace.' In M. Brown and S. Lynn-Jones and S. Miller (eds.) Debating the Democratic Peace. Massachusetts: The MIT Press.

Said, Edward. (2004) Orientalism. New York: Vintage Books. Originally published in 1977.

Sanders, Jerry. (1983) Peddlers of Crisis: The Committee on the Present Danger and the Politics of Containment. Boston: South End Press.

Sanger, David. (2009) The Inheritance: The World Obama Confronts and the Challenges to American Power. London: Bantam Press.

Schlesinger, Arthur. (1949) The Vital Center: The Politics of Freedom. Boston: Houghton Mifflin.

Schlesinger, Arthur. (1967-1968) 'Origins of the Cold War,' Foreign Affairs, vol. 46, pp. 22-52.

Schlesinger, Arthur. (2004) The Imperial Presidency. Boston and New York: Houghton Mifflin Company. Originally published in 1973.

Schwartz, Peter. (1995) 'Warrior in the Age of Intelligent Machines,' Wired, http://www.wired.com/wired/archive/3.04/pentagon.html, Date accessed 09/03/2007.

Sharansky, Natan. (2004) The Case for Democracy: The Power of Freedom to Overcome Tyranny \& Terror. New York: Public Affairs.

Shawcross, William. (2004) Allies: The U.S. and the World in the Aftermath of the Iraq War. Sydney: Allen and Unwin. 
Shirk, Susan. (2008) China: Fragile Superpower: How China's Internal Politics Could Derail its Peaceful Rise. Oxford and New York: Oxford University Press.

Sikkink, Kathryn. (1993) 'The Power of Principled Ideas: Human Rights Policies in the United States and Western Europe.' In J. Goldstein and R. Keohane (eds.) Ideas and Foreign Policy: Beliefs, Institutions, and Political Change. Ithaca and London: Cornell University Press.

Singer, Peter. (2004) The President of Good and Evil: The Ethics of George W. Bush. Melbourne: The Text Publishing Company.

Singh, Robert. (2009) 'Neo-Conservatism: Theory and Practice.' In I. Parmar and L. Miller and M. Ledwidge (eds.) New Directions in US Foreign Policy (forthcoming). London: Routledge.

Slaughter, Anne M. (2007) The Idea That Is America: Keeping Faith with Our Values in a Dangerous World. New York: Basic Books.

Slaughter, Anne M. (2009) 'Wilsonianism in the Twenty-First Century.' In J. Ikenberry, T. Knock, A.M. Slaughter, and T. Smith (eds.) The Crisis of American Foreign Policy. Princeton and Oxford: Princeton University Press.

Smith, Michael. (1986) Realist Thought: From Weber to Kissinger. Baton Rouge: Louisiana State University.

Smith, Tony. (1994) America's Mission: The United States and the World Wide Struggle for Democracy in the Twentieth Century. Princeton and New Jersey: Princeton University Press.

Smith, Tony. (2007) A Pact with the Devil: Washington's Bid for World Supremacy and the Betrayal of the American Promise. New York and London: Routledge.

Snidal, Duncan. (1985) 'The limits of hegemonic stability theory,' International Organization, vol. 39, no. 4 (Autumn), pp. 579-614.

Solomon, Lewis. (2007) Paul D. Wolfowitz: Visionary Intellectual, Policymaker, and Strategist. Westport, Connecticut and London: Praeger Security International.

Steinfels, Peter. (1979) The Neoconservatives: the men who are changing America's politics. New York: Simon and Schuster.

Stelzer, Irwin. (2004) 'Neoconservatives and their Critics: An Introduction.' In I. Stelzer (ed.) The Neocon Reader. New York: Grove Press.

Stern, Jessica. (2003) Why Religious Militants Kill: Terror in the Name of God. New York: HarperCollins. 
Strauss, Leo. (1978) The City and Man. Chicago: University of Chicago Press. Originally published in 1964.

Strauss, Leo. (1988) Persecution and the Art of Writing. Chicago: University of Chicago Press. Originally published in 1952.

Strauss, Leo. (1989) An Introduction to Political Philosophy: Ten Essays by Leo Strauss. Detroit: Wayne State University Press.

Suskind, Ron. (2007) The One Percent Doctrine: Deep Inside America's Pursuit of its Enemies since 9/11. New York: Simon and Schuster.

Takeyh, Ray. (2006) Hidden Iran: Paradox and Power in the Islamic Republic. New York: Halt Paperbacks.

Tanguay, Daniel. (2003) Leo Strauss: An Intellectual Biography. New Haven: Yale University Press.

The 9/11 Commission Report: Final Report of the National Commission on Terrorist Attacks Upon The United States (2003). New York and London: W.W. Norton \& Company.

The Foreign Policy Initiative Mission Statement, (2009). The Foreign Policy Initiative, http://wwwforeignpolicyi.org/about.html, Date accessed 15/04/2009.

Trachtenberg, Marc. (1999) A Constructed Peace: The Making of the European Settlement, 1945-1963. Princeton: Princeton University Press.

Trachtenberg, Marc. (2007) 'Preventive War and U.S. Foreign Policy,' Security Studies, volume. 16, issue. 1, pp. 1-31.

Transatlantic Trends. (2007) http://www/transatlantictrends.org/trends/index.cfm?year=2007, Date accessed 04/04/2008.

Traub, James. (2008) The Freedom Agenda: Why America Must Spread Democracy (Just Not the Way George Bush Did). New York: Farrar, Straus, and Giroux.

Wald, Alan. (1987) The New York Intellectuals: the Rise and Decline of the antiStalinist left from the 1930s to the 1980s. North Carolina: The University of North Carolina Press.

Walker, Stephen. (1977) 'The Interface between Beliefs and Behaviour: Henry Kissinger's Operational Code and the Vietnam War,' Journal of Conflict Resolution, vol. 21, no. 1 (March), pp.129-168. 
Walt, Stephen. (1987) The Origins of Alliances. Ithaca and London: Cornell University Press.

Walt, Stephen. (2005) Taming American Power: The Global Response To U.S. Primacy. New York and London: W.W. Norton \& Company.

Waltz, Kenneth. (1959) Man, the State, and War. New York: Columbia University Press.

Waltz, Kenneth. (2002) 'Structural Realism after the Cold War.' In J. Ikenberry (ed.) America Unrivalled: The Future of the Balance of Power. Ithaca and London: Cornell University Press.

Walzer, Michael. (2006) Just and Unjust Wars: A Moral Argument with Historical Illustrations. New York: Basic Books.

Weart, Spencer. (1998) Never at War: Why Democracies Will Not Fight One Another. New Haven and London: Yale University Press.

Weiner, Tim. (2007) Legacy of Ashes: The History of the CIA. New York: Allen Lane.

Wendt, Alexander. (1999) Social Theory of International Politics. Cambridge and New York: Cambridge University Press.

Wesley, Michael. (2005) 'It's time to scrap the NPT,'Australian Journal of International Affairs, vol. 59, no. 3 (September), pp. 283-299.

West, Bing. (2008) The Strongest Tribe: War, Politics, and the Endgame in Iraq. New York: Random House.

West, Thomas. (2005) Leo Strauss and American Foreign Policy, http://www.claremont.org/publications/crb/id.1075/article_detail.asp, Date accessed 05/06/2005.

Westad, Odd A. (2004) 'Reagan's anti-Revolutionary Offensive in the Third World.' In O. Njolstad (ed.) The Last Decade of the Cold War: From Conflict Escalation to Conflict Transformation. London and New York: Frank Cass.

Westad, Odd A. (2007) The Global Cold War. Cambridge and New York: Cambridge University Press.

Wheeler, Nicolas. (2002) Saving Strangers: Humanitarian Intervention in International Society. Oxford and New York: Oxford University Press.

Wight, Colin. (2006) Agents, Structures and International Relations: Politics as Ontology. Cambridge and New York: Cambridge University Press. 
Williams, Michael. (2005) 'What is the National Interest? The Neoconservative Challenge in IR Theory,' European Journal of International Relations, vol. 11, no. 3, pp. 307-337.

Wilson, James Q. (1996) 'Forward.' In M. Gerson (ed.) The Essential Neoconservative Reader. Massachusetts: Addison-Wesley Publishing Company.

Wisse, Ruth. (1987) 'The New York Intellectuals,' Commentary, vol. 84, issue. 5, pp. 28-39.

Wohlforth, William. (1993) The Elusive Balance: Power and Perceptions During the Cold War, Ithaca and London: Cornell University Press.

Wohlforth, William. (1999) 'The Stability of a Unipolar World,' International Security, vol. 24, no. 1 (Summer), pp. 5-41.

Wohlstetter, Albert. (1983) 'Bishops, Statesmen, and Other Strategists on the Bombing of Innocents,' Commentary, June, pp. 15-35.

Wohlstetter, Albert. (1985) 'Between an Unfree World and None: Increasing our Choices,' Foreign Affairs, vol. 63, issue. 5, pp. 962-994.

Wohlstetter, Albert. (1992) 'Help Iraqi Dissidents Oust Saddam,' Wall Street Journal, August 25, p. A14.

Wohlstetter, Albert. (1994a) 'Genocide by Embargo,' Wall Street Journal, May 9, p. A14.

Wohlstetter, Albert. (1994b) 'Arms, not words, for Bosnia,' The Wall Street Journal, May 12, A14.

Wohlstetter, Albert. (1995) 'A nuclear treaty that breeds weapons,' The Wall Street Journal, April 4, p. A20.

Wolfson, Adam. (2004) 'Conservatives and Neoconservatives,' The Public Interest, no. 154, Winter 2004, pp. 32-48.

Wolfowitz, Paul. (1994) 'Clinton's first year,' Foreign Affairs, vol. 73, no. 1 (Jan-Feb), pp. 28-43.

Wolfowitz, Paul. (2000) 'Statesmanship and the New Century.' In R. Kagan and W. Kristol (eds.) Present Dangers: Crisis and Opportunity in American Foreign and Defense Policy. San Francisco: Encounter Books.

Wolfowitz, Paul. (2001a/2004) 'Ballistic Missile Defense.' In L. Crane (ed.) Wolfowitz On Point. Philadelphia: Pavilion Press.

Wolfowitz, Paul. (2001b/2004) 'A Military for the Twenty-First Century.' In L. Crane (ed.) Wolfowitz On Point. Philadelphia: Pavilion Press. 
Wolfowitz, Paul. (2002/2004) 'The Muslim World.' In L. Crane (ed.) Wolfowitz On Point. Philadelphia: Pavilion Press.

Wolfowitz, Paul. (2003) 'Deputy Secretary Wolfowitz Interview with Sam Tannenhaus, Vanity Fair, www.defenselink.mil/transcripts/2003/tr20030509depsecdef0223.html, Date accessed 12/03/2007.

Wolfowitz, Paul. (2005) 'Paul Wolfowitz: I'm Not a Unilateralist,' http://www.newsweek.com/id/49527, Date accessed 08/04/2007.

Wood, Gordon. (2007) Revolutionary Characters: What Made the Founders Different. New York: Penguin Books.

Woods, Kevin, Lacey, James and Williamson, Murray. (2006) 'Saddam's Delusions: The View from the Inside,' Foreign Affairs, vol. 85, issue. 3 (May/June), pp. 2-27.

Woodward, Bob. (2004) Plan of Attack. Simon and Schuster: New York.

Woodward, Bob. (2005) Bush at War. Simon and Schuster Paperbacks: New York.

Wright, Lawrence. (2006) The Looming Tower: al-Qaeda and the Road to 9/11. New York: Vintage Books.

Zakaria, Fareed. (1993) 'The Core vs. the Periphery,' Commentary, vol. 96, issue. 6, pp. 25-30.

Zakaria, Fareed. (2008) The Post-American World. New York and London: W.W. Norton \& Company.

Zuckert, Michael. (1994) Natural Rights and the New Republicanism. Princeton: Princeton University Press.

Zuckert, Michael. (1996) The Natural Rights Republic. Notre Dame: University of Notre Dame.

Zuckert, Michael. (2002) Launching Liberalism: On Lockean Political Philosophy. Lawrence: University Press of Kansas.

Zuckert, Catherine and Zuckert, Michael. (2006) The Truth About Leo Strauss: Political Philosophy and American Democracy. Chicago. The University of Chicago Press. 


\section{Interviews with the Author}

Ethical clearance was requested and obtained from Griffith University to conduct the following interviews. All participants signed a consent form, agreeing to take part in this research project.

Kristol, William. Interview, face to face, tape recorded, 21 February 2007.

Lieber, Robert. Interview, face to face, tape recorded, 16 February 2007.

Lieven, Anatol. Interview, face to face, tape recorded, 17 February 2007.

Lind, Michael. Interview, face to face, tape recorded, 15 February 2007.

Muravchik, Joshua. Interview, face to face, tape recorded, 20 February 2007.

Perle, Richard. Interview, telephone, noted, 23 February 2007. 